JULIANA BIERRENBACH BONETTI.

\title{
RESPONSABILIDADE PENAL PELO PRODUTO
}

Dissertação de Mestrado apresentada à Banca Examinadora da Faculdade de Direito da Universidade de São Paulo, como exigência parcial para a obtenção do título de Mestre em Direito, sob orientação do Prof. Titular Miguel Reale Júnior

FACULDADE DE DIREITO DA USP

SÃO PAULO 
Banca Examinadora 
À Maria Julia. Para que ela se inspire a buscar cada um de seus sonhos. 


\section{AGRADECIMENTOS}

Agradeço, inicialmente, aos Professores Geraldo Prado e Leonardo Sica por terem me recebido em seus escritórios no momento em que o ingresso na Pós Graduação era apenas um sonho. Agradeço a ambos pelas elucidações a respeito do extenso processo seletivo que eu estava por enfrentar.

Agradeço, também, ao Professor Diogo Malan por ter me auxiliado na elaboração de meu Projeto de Pesquisa, me enviando, generosamente, como modelo, aquele com o qual ingressou no Programa de Pós Graduação em Direito da Universidade de São Paulo.

Quero agradecer, de maneira especial, ao Professor Miguel Reale Júnior por ter me recebido no Programa de Pós Graduação e orientado magistralmente meu trabalho dissertativo.

Agradeço, ainda, aos Professores Renato de Mello Jorge Silveira e Alamiro Velludo por seus fundamentais apontamentos em meu Exame de Qualificação. Tanto a estrutura quanto a bibliografia do presente trabalho foram, significativamente, afetadas por suas cuidadosas leituras seguidas de indicações precisas e excepcionais.

Meu profundo agradecimento, aos funcionários do IBCCRIM, por toda a atenção dedicada e eficiência demonstrada nos longos dias em que passei na sede do Instituto pesquisando e escrevendo, bem como, a todos os funcionários das Bibliotecas e Secretaria da Pós Graduação da Faculdade de Direito do Largo de São Francisco da Universidade de São Paulo, pelo exemplo de eficiência e, especialmente, pelo carinho dispensado no tratamento aos alunos neste, que é um momento tão importante e de tamanha tensão.

Quero, também, deixar registrada a minha gratidão a todos os funcionários do Fazenda Café e do Itamarati, em especial ao Miranda que, sempre com um sorriso no rosto, nos atendia após as aulas da Pós.

Agradeço à minha funcionária particular, Márcia, por ter ficado na retaguarda de minha casa, fornecendo à minha filha todo o auxilio necessário neste período em que passei afastada para comparecer às aulas e, principalmente, elaborar este trabalho.

Agradeço, imensamente, à minha amiga Thamis Ávila Dalsenter, por sua paciente e acurada revisão de meu texto, sempre acrescentando pontos fundamentais com suas sugestões pertinentes e pontuais. 
Quero agradecer, ainda, aos amigos que fiz nas salas de aula da São Francisco, em especial Gilberto Bergstein, Camilla Bemergui, Mariana Guimarães Rocha, Fernando José da Costa e João Paulo Martinelli, sem a presença dos quais, este processo teria sido ainda mais difícil e, certamente, muito menos divertido.

Ao meu Tio Flávio Flores da Cunha Bierrenbach, por ter me apontado o caminho excelência da Faculdade de Direito do Largo de São Francisco.

Agradeço, de modo particular, à minha Tia Maria Luiza Flores da Cunha Bierrenbach, por ter me incentivado e apoiado, desde o início desta caminhada, há quase dez anos, quando tomei a decisão de voltar a me dedicar aos estudos do Direito, reiniciando a graduação, abandonada anos antes. Por ter me recebido com todo carinho e cuidado em sua casa, durante o período em que compareci, semanalmente, às aulas da Pós. Mais ainda, por dedicar a mim palavras e gestos que, habitualmente, guardamos exclusivamente para nossos filhos.

Agradeço a meu Avô Julio de Sá Bierrenbach, por ser para mim, desde a infância, um modelo de força, integridade e caráter. Mais do que um avó, é um pai que proporciona todas as condições necessárias à realização dos meus projetos pessoais, dentre os quais o estudo do Direito, ocupa lugar de destaque.

Quero, ainda, agradecer, especialmente, à minha filha, Maria Julia Bierrenbach Pollastri, por ter aturado a minha ausência no primeiro ano de Mestrado, quando precisei ir semanalmente a São Paulo cumprir meus créditos. Mas, sobretudo, por ter suportado, paciente e compreensivamente, meu isolamento e consequente distanciamento, para que pudesse escrever as páginas que compõem esse trabalho. Nesta difícil fase da vida, transição da infância para a vida adulta, na qual os filhos tendem a tornar-se quase que estranhos aos pais, minha filha tem me dado a alegria e o orgulho de perceber que criei uma menina ajuizada, companheira, compreensiva e que tem, acima de tudo, bons e raros valores balizando seu comportamento adolescente.

Mais do que a qualquer outro, agradeço a Deus por ter me dado forças, permanecendo ao meu lado e, muitas vezes, me carregando no colo, para que eu conseguisse terminar este trabalho em um momento tão turbulento de minha vida pessoal. 
"Não sabemos se vivemos num mundo algo mais arriscado que aquele das gerações passadas. Não é a quantidade de risco, mas a qualidade do controle ou, para ser mais preciso, a sabida impossibilidade de controle das decisões civilizacionais que faz a diferença histórica". (Ulrich Beck) 


\section{RESUMO}

A presente dissertação trata da possibilidade de imputação de responsabilidade penal decorrente do resultado, de perigo ou dano, à saúde, integridade física ou vida do consumidor pela fabricação ou comercialização de produtos defeituosos. Sendo a responsabilidade penal, ainda que no âmbito da empresa, sempre subjetiva, procurou-se estabelecer limites à referida imputação, tendo como baliza o nexo de causalidade entre o resultado juridicamente indesejado e a conduta pessoal do agente, ainda que restrita à tomada de decisão dentro de sua esfera de responsabilidade e possibilidade real de atuação. Percebendo a insuficiência do ordenamento jurídico-penal brasileiro para o tratamento da questão estudada, foram propostos, de lege ferenda, tipos penais adequados à necessidade de tutela do consumidor diante da possibilidade de serem-lhe impostos riscos imprevisíveis

Palavras-chave: Direito Penal; consumidor; fornecedor; produto; perigo; periculosidade; responsabilidade penal empresarial subjetiva 


\begin{abstract}
This essay deals with the possibility of imputation of criminal liability arising from the result, danger or damage, against health, physical integrity or life of the consumer by manufacture or marketing of defective products. Being the criminal liability, even within the company, always-subjective, the dissertation pursued to establish limits to the imputation, taking as a reference the causal link between the result legally undesired and personal conduct of the agent, even if restricted to the observation of objective commitments of care and the capacity for decision making within its sphere of responsibility and real possibility of action. Realizing the inadequacy of the Brazilian criminal legal order for a more accurate aproach of the studied question, were proposed, lege ferenda appropriate criminal types, aiming the need to protect the consumer in forseeing the possibility of imposing them to unforeseeable risks
\end{abstract}

\title{
Keywords:
}




\section{SUMÁRIO}

\section{DIREITO PENAL E A CRIMINALIZAÇÃO DO PERIGO COMO ESSENCIAIS}

\section{À TUTELA DA VIDA EM SOCIEDADE. O PAPEL DA TEORIA DO BEM JURÍDICO.}

1.1. Sociedade de Risco e o papel do Direito Penal na tutela do indivíduo e da sociedade frente à nova configuração social

1.2. Insuficiência de outros ramos do Direito tutelarem a nova realidade social: o Direito Penal como ultima ratio frente à delinqüência no âmbito da empresa

1.3. Perigo e a necessidade de sua criminalização. A antecipação do resultado delituoso ..................27

1.4. Norte de toda a criminalização: a teoria do bem jurídico ............................................................. 31

\section{O PROTAGONISMO DAS RELAÇÕES DE CONSUMO COMO FONTE DE} CONFLITOS SOCIAIS E JURÍDICOS E SUA CONSEQUENTE TUTELA PENAL. O PAPEL DO PRODUTO NESSA REALIDADE .................................................41

2.1. O papel das relações de consumo na geração de conflitos sociais e demandas judiciais..............41

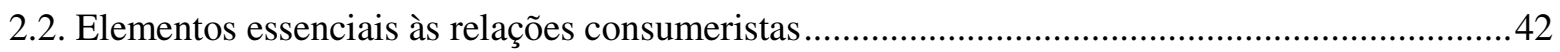

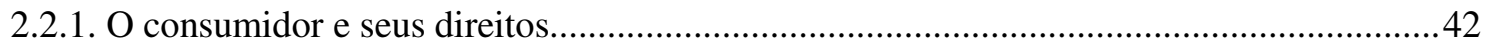

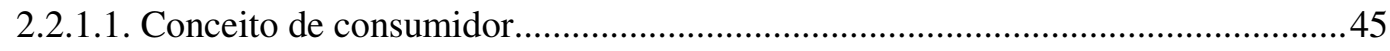

2.2.1.2. Direitos do consumidor relativos à colocação de produtos no mercado ................45

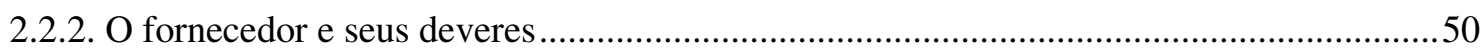

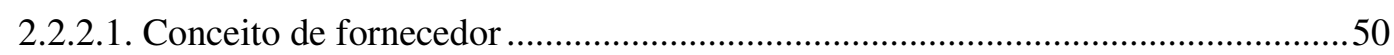

2.2.2.2. Deveres do fornecedor de produtos ..................................................................52

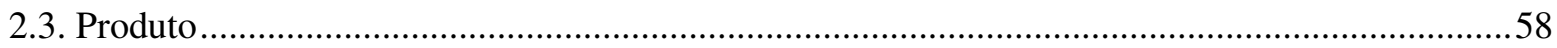

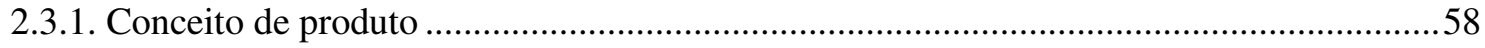

2.3.2. Legítima expectativa como princípio geral da segurança dos bens de consumo ...............60

2.3.3. A periculosidade dos produtos e os riscos impostos aos consumidores..............................64

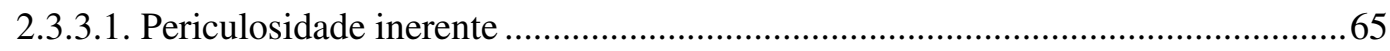

2.3.3.2. Periculosidade exagerada ............................................................................6 66

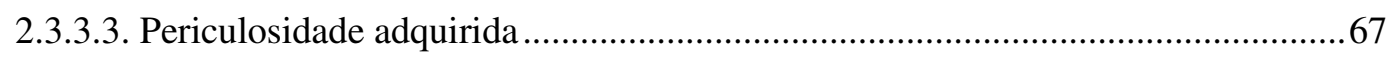

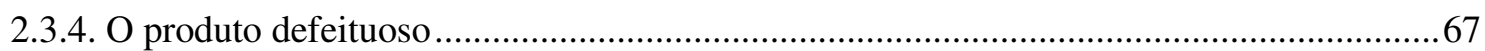

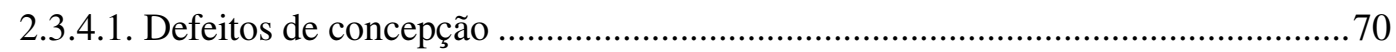

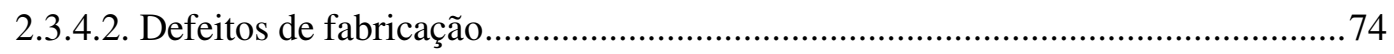


2.4. O Direito como tutela às relações de consumo e ao consumidor: principais diplomas normativos .78

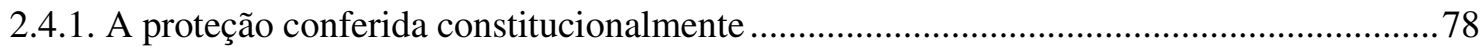

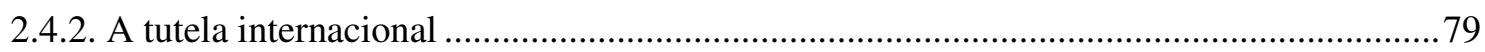

2.4.3. A defesa infraconstitucional das relações de consumo e do consumidor............................ 81

2.4.4. O Sistema Nacional de Vigilância Sanitária .......................................................................... 83

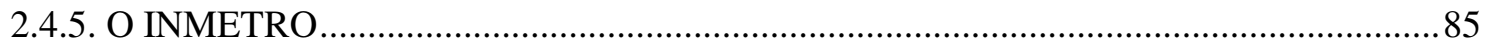

2.4.6. Liberação de produto ao mercado de consumo no Brasil....................................................90

2.5. Excessos e insuficiências da tutela penal do consumidor e das relações de consumo no que se refere à produção e comercialização de produtos

\section{RESPONSABILIDADE PENAL SUBJETIVA NO CENÁRIO EMPRESARIAL.} DIFICULDADES E CAMINHOS PARA SUA IMPUTAÇÃO DE ACORDO COM OS PARÂMETROS CONSTITUCIONAIS

3.1. Responsabilidade penal da Pessoa Jurídica. 101

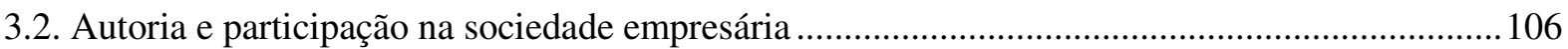

3.3. Responsabilidade no cenário empresarial. Capacidade de tomada de decisão .............................113

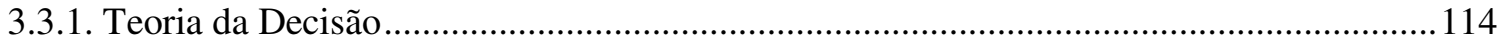

3.3.2. Divisão de responsabilidades e o Princípio da Confiança.................................................... 116

3.3.3. Decisões tomadas individualmente ou por meio de órgãos colegiados................................116

3.3.4. Responsabilidade subjetiva na seara empresarial.

3.3.4.1. Responsabilidade penal dos membros da estrutura orgânica da sociedade empresária.

3.3.4.2. A responsabilidade penal dos técnicos e peritos

3.3.4.3. A responsabilidade penal dos diversos empregados da sociedade empresária ....131

3.4. Responsabilidade pelo produto na União Européia

3.5. Produto e resultado: dificuldades na verificação do curso causal.................................................134

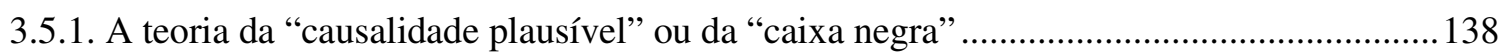

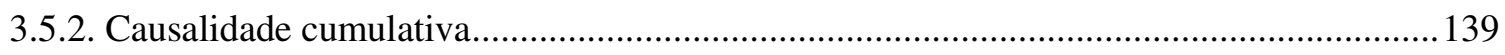

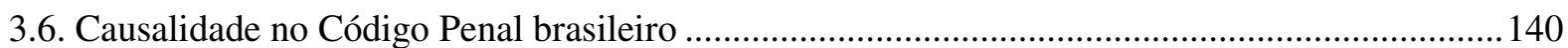

4. NECESSIDADE E LIMITES A UMA RESPONSABILIDADE PENAL PELO PRODUTO. 
4.1. A deficiência do ordenamento jurídico-penal brasileiro e a necessidade de elaboração de normas que tutelem a produção e comercialização de produto ao menos potencialmente lesivo

4.2. Limites a uma responsabilidade penal pelo produto

4.3. Tipos propostos de lege ferenda: a criminalização da produção e colocação no mercado de consumo de produto que exponha o consumidor a perigo ........................................................... 151

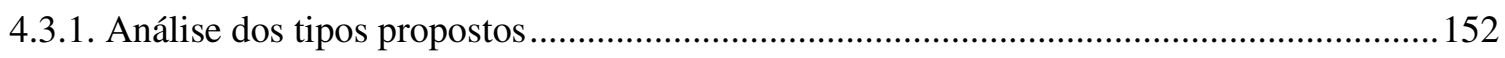

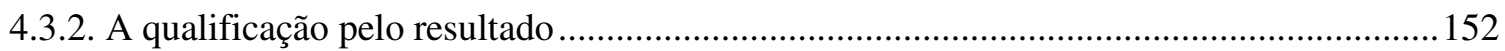

4.4. Casos paradigmáticos da responsabilidade penal pelo produto: descrição, análise e

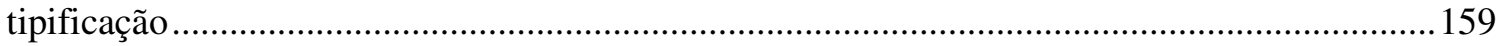

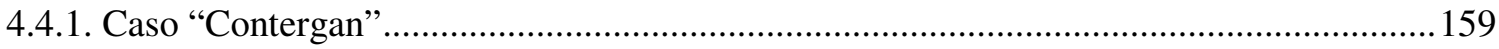

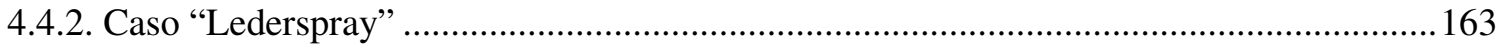

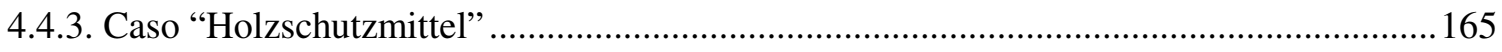

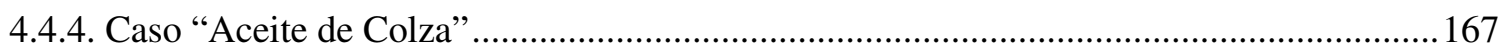

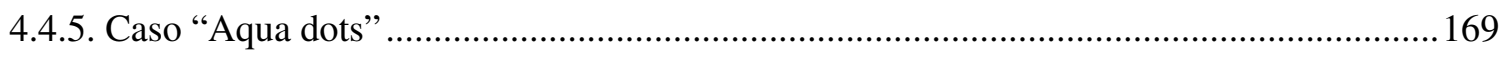

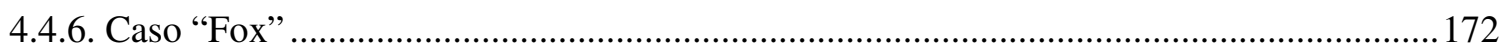

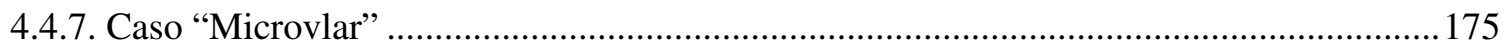

CONCLUSÃO

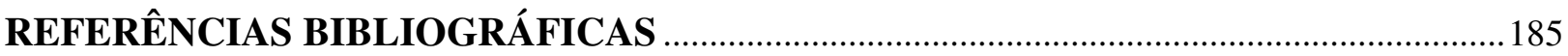




\section{INTRODUÇÃO}

O mundo vive, atualmente, um momento de profundas transformações decorrentes do incremento no desenvolvimento tecnológico alcançado pelo homem. Associado ao desenvolvimento, vêm os riscos dele originados. Diferentemente do imaginado, o progresso não traz apenas benefícios ao homem, mas, também, um enorme potencial de perigo que acaba por refletir nas mais diversas áreas de atuação humana.

Destaca-se neste cenário, o potencial de nocividade e lesividade que pode vir agregado a produtos destinados ao mercado de consumo, especialmente, àqueles oriundos de produção e comercialização em massa.

A administração pública, por meio de suas agências reguladoras, não consegue controlar adequadamente a qualidade, naquilo que se refere à segurança, dos produtos lançados no mercado de consumo. A ANVISA, por exemplo, não testa os produtos que certifica, limitando-se a testar os documentos enviados ao órgão pelas empresas interessadas em obtenção de seu certificado. Deste modo a disparidade entre as características declaradas e as informações ali prestadas podem só ser percebidas posteriormente, quando o perigo imposto ao consumidor pelo produto que não atenda as suas legítimas expectativas de segurança, tiver gerado um resultado lesivo.

O ordenamento jurídico-penal brasileiro, por sua vez não tem instrumentos capazes de punir adequadamente os responsáveis pelo produto perigoso, capaz de atingir os bens jurídicos do consumidor. As regras relativas à causalidade e autoria não ficam claras quando transpostas para o âmbito da empresa, sendo de difícil estabelecimento a responsabilidade subjetiva. A dificuldade, no entanto, não pode ser entendida como impossibilidade nem como inadequação ao recurso penal como reforço na tutela social nesta seara.

Assim, este trabalho teve como objetivo o estudo da possibilidade de responsabilização penal pela produção e comercialização de produtos disponibilizados no mercado de consumo que sejam capazes de gerar um potencial de risco ao consumidor.

A pesquisa foi desenvolvida em quatro capítulos. No primeiro procurou-se estabelecer a essencialidade do Direito Penal à tutela da sociedade, especialmente, neste cenário de novos riscos impostos ao homem. Frisou-se, contudo a necessidade de que a 
referida tutela seja efetiva e não meramente simbólica. Neste sentido, para que não seja arbitrariamente limitada a liberdade de atuação humana, utilizou-se a teoria do bem jurídico como baliza essencial à criminalização de condutas. Naquilo que diz respeito à proteção do consumidor, estabeleceram-se os bens jurídicos vida, saúde e integridade física como os merecedores da proteção ultima ratio do Direito Penal, sendo à propriedade, suficientemente protegida pelo Direito Civil. Tais bens jurídicos foram considerados dignos de tutela penal, tendo em vista o potencial de serem colocados em perigo pelo fornecimento de produtos e prestação de serviços, bem como, pela possibilidade de os fornecedores repassaram ao consumidor eventuais prejuízos decorrentes de pagamentos de indenizações de responsabilidade civil.

No segundo capítulo as relações de consumo são apresentadas como principal fonte de demandas de conflitos sociais e judiciais devido à posição central que o consumo passou a ocupar na economia e na vida dos indivíduos. Os atores das relações de consumo, consumidor e fornecedor, foram, então, identificados em detalhes, assim como seus direitos e deveres, respectivamente. Em seguida, procurou-se estabelecer a importância do produto neste cenário. Para conceituar fornecedor, consumidor e produto foram aproveitados os conceitos dados pelo próprio Código de Defesa do Consumidor, que traz também as noções elementares ao tema em estudo como a legítima expectativa de segurança do consumidor em relação aos produtos a ele fornecidos. Posteriormente, procurou-se estabelecer o conceito de periculosidade, distinguindo várias formas de apresentação. Ainda neste capítulo, foi conceituado o produto defeituoso, entendido como aquele capaz de deflagrar a responsabilização penal, bem como as espécies de defeitos definidores de sua origem. Para concluir, foram elencados os principais diplomas normativos que visam a tutela do consumo e do consumidor e apontados os excessos e insuficiências nesta realidade normativa.

No terceiro capítulo, tratou-se de estabelecer a responsabilidade penal no cenário empresarial, apontando as dificuldades e os caminhos para sua imputação. A possibilidade de responsabilizar penalmente a Pessoa Jurídica foi afastada e, a partir daí, foram estabelecidos critérios para verificação de responsabilidade penal subjetiva ao longo da cadeia empresarial. Neste sentido, foram estabelecidos como critérios fundamentais a capacidade de tomada de decisão e os deveres de cuidado e garantia. Estabeleceu-se o domínio do fato como teoria a partir da qual se verifica a autoria criminosa. Determinou-se como adequada à verificação de responsabilidade penal no âmbito da empresa a distinção 
de tratamento decorrente da diferença em relação à estrutura da empresa, seja ela menos ou mais complexa. A partir daí, detalhou-se a possibilidade de autoria de cada possibilidade de atuação, estabelecendo a eventual responsabilidade de cada agente. Para o concluir o capítulo foram elencadas as dificuldades relativas ao estabelecimento do nexo causal, bem como, o tratamento da causalidade pela ordem jurídica brasileira.

Diante da percepção da necessidade da tutela penal para o tratamento da responsabilidade pelo produto e da constatação da existência de lacuna no ordenamento jurídico para a adequada resposta à questão, entendeu-se conveniente estabelecer limites à dita responsabilidade, assim como, propor tipos penais destinados ao preenchimento da referida omissão. Deste modo, foram apresentados como limites: a proteção dos bens jurídicos saúde, integridade física e vida; os princípios Societas delinquere non potest, da Lesividade, da Intervenção Mínima e da Culpabilidade. Finalizando, foram, ainda, propostos três tipos penais, de perigo concreto, destinados às esferas de responsabilidade nos diversos momentos que há entre a concepção do produto e o seu contato com o consumidor. Um quarto tipo qualifica as condutas por eventual realização do perigo no resultado. Para concluir o trabalho, foram apresentados casos de responsabilidade penal pelo produto e, naqueles em que os produtos estiveram presentes no mercado de consumo brasileiro foram testados os tipos penais apresentados. 


\subsection{O Direito PENAL E A CRIMinalizaÇÃo do PERIgo COMO ESSENCIAIS À TUTELA DA VIDA EM SOCIEDADE. O PAPEL DA TEORIA DO BEM JURÍDCO}

\subsection{A Sociedade de Risco e o papel do Direito Penal na tutela do indivíduo e da sociedade frente à nova configuração social}

Quando, em julho de 1764, CESARE BECCARIA tornou públicas ${ }^{1}$ suas idéias, tidas, então, como revolucionárias, a respeito das orientações que deveriam ser observadas pelo Poder Público no exercício do jus puniendi, urgia, no cenário do mundo ocidental, uma mudança de paradigma em relação às penas impostas Estado a seus cidadãos. As mais crueis sanções eram, então, institucionalizadas sem nenhum tipo de limite e não havia garantias individuais. Poucos anos depois, em 1789, com o advento da Revolução Francesa, foi proclamada a Declaração dos Direitos dos Homens e dos Cidadãos, respondendo aos anseios de liberdade da sociedade da época, previamente elencados por BECCARIA, positivados, como forma de preservar os cidadãos frente ao abuso de poder daqueles que o detinham. Liberdades e direitos fundamentais do homem, desta forma, foram garantidos em um preâmbulo e dezessete artigos que compõem a Declaração.

Nos dias atuais, muitas violações aos Direitos Humanos ainda continuam ocorrendo. No Brasil, a maioria delas, não mais de forma institucionalizada ${ }^{2}$. Hoje, os cidadãos da maioria dos países civilizados, dispõem de instrumentos legais que lhes permitem lutar contra os abusos de poder praticados pelo Estado.

Outra forma de abuso de poder, porém, vem ganhando espaço no cenário internacional. Trata-se do poder concentrado nas mãos daqueles que têm a possibilidade de tomar decisões que poderão vir a afetar indeterminável, espacial e temporalmente, parcela impotente da população. Tendo como finalidade precípua a busca pelo lucro desenfreado ou pelo desenvolvimento tecnológico, tais tomadas de decisão ocorrem, principalmente, no âmbito das empresas e apresentam a particularidade de colocar uma nem sempre definível

\footnotetext{
${ }^{1}$ BECCARIA, Cesare. Dos delitos e das penas. São Paulo: Martins Fontes, 1997.

${ }^{2}$ Uma exceção a esta regra, certamente, é o Regime Disciplinar Diferenciado, instituído pela Lei $\mathrm{n}^{\circ}$. 10.792/2003, que pode ser considerado uma forma de violação institucionalizada aos Direitos Humanos, uma vez que coloca os encarcerados sob sua égide em situações de privação que afrontam diretamente a dignidade da pessoa humana.
} 
quantidade de pessoas diante de riscos, ao menos num primeiro momento, indetectáveis, imensuráveis e incontroláveis.

A desenfreada busca por lucros ilimitados, por mercados cada vez mais amplos e pelo desenvolvimento tecnológico irrefreável, empreendida pelas empresas por intermédio de seus representantes, responsáveis por tomadas de decisão em seu âmbito, torna o mundo, a cada dia, mais inseguro e vulnerável aos riscos ubíquos, locais e globais, invisíveis e indetectáveis ${ }^{3}$. Em meio às referidas empresas, encontram-se aquelas que produzem ou colocam em circulação no mercado, produtos, nem sempre seguros ao uso ou consumo a que se destinam, gerando, desta forma os riscos aludidos.

Em seu livro La Sociedad del riesgo: Hacia una nueva modernidad ${ }^{4}$, o sociólogo alemão ULRICH BECK chama atenção do mundo para esses novos riscos, demonstrando a necessidade de mudança de paradigma nas mais diversas esferas sociais, para que tenhamos a possibilidade de lidar com esta nova forma de modernidade por ele apresentada, a chamada modernidade reflexiva. Nesta fase da modernidade, a própria sociedade pode ser destruída como consequência de seu progresso técnico-econômico, em decorrência de seus efeitos colaterais ${ }^{5}$. Dito de outro modo, sempre se imaginou que o desenvolvimento tecnológico atingiria um ponto em que, por dominar a natureza, o homem estaria virtualmente livre dos riscos dela advindos, que seriam, ao menos, bastante diminuídos. Isso, efetivamente ocorreu em diversos aspectos da vida, como por exemplo, no controle e erradicação de algumas doenças, conquistado por meio dos avanços da indústria fármaco-química. O que não se esperava, no entanto, é que haveria uma série de efeitos secundários relativos a esse desenvolvimento. Desta forma, ao produzir bens de consumo, por exemplo, a indústria traz inerentes a esta produção, riscos àqueles que, por ventura, vierem a ter contato com os referidos bens, pois, além do potencial de cumprir a

\footnotetext{
${ }^{3}$ FERNANDES, Paulo Silva. O direito penal no amanhecer do século XXI: breves questões à luz do paradigma da "sociedade de risco". Sub judice: justiça e sociedade, Lisboa, n. 19, p. 111-127, dez. 2001.

${ }^{4}$ BECK, Ulrich. La sociedad del riesgo: hacia una nueva modernidad. Traduzido por Jorge Navarro, Daniel Jimenez, Maria Rosa Borras. Barcelona: Paidós, 2006. (Colección Surcos).

${ }^{5}$ Beck, explica: "La fase inicial de la cientificación (la conceptuación bajo criterios científicos de amplios aspectos de la existencia humana) primaria (...) hace mucho tiempo que finalizó y con ella se puso fin al mito de la superioridad y a la inclinación al poder que caracterizaba la relación entre ciencia, práctica y vida pública. (...) En su lugar, casi en todas partes, han aparecido los conflictos y relaciones de la cientificación reflexiva: la civilización científica ha entrado en una fase en la cual ya no es sólo la naturaleza, el hombre y la sociedad lo que se somete a criterios científicos sino también ella misma, sus productos, consecuencias y defectos. Ya no se trata, pues, de la "liberación de las dependencias preexistentes”, sino más bien de la definición y atribución de los errores y riesgos autogenerados”. BECK, Ulrich. op. cit., p. 206-207.
} 
função a que se destinam trazem a eles agregada a capacidade de colocar em risco ou mesmo efetivamente lesar bens jurídicos individuais dos consumidores.

ULRICH BECK $^{6}$, ANTHONY GIDDENS ${ }^{7}$ e SCOTT LASH $^{8}$ se opõem aos autores que defendem um conceito de pós-modernidade e entendem que a sociedade ainda está vivendo a modernidade, numa fase, porém, tardia denominada modernidade reflexiva. ${ }^{9}$ Neste momento social, a sociedade se caracteriza por ter o risco como elemento central, sendo, por isso, denominada como Sociedade de Risco. Segundo BECK, o risco é um conceito moderno que se refere a incertezas imensuráveis, não quantificáveis, ou seja, incalculáveis, fabricadas pelas inovações tecnológicas e respostas sociais aceleradas ${ }^{10}$.

A reflexividade, neste sentido, assume papel central na transição da sociedade industrial para a sociedade de risco, tendo em vista os efeitos colaterais da sociedade industrial. Isto porque, como referido anteriormente, o ideal moderno de controle da natureza para um perfeito desenvolvimento industrial jamais se concretizou, e, desta forma, os malefícios, aqui entendidos como efeitos colaterais ou secundários, não puderam ser controlados pela razão humana. Ao contrário, foram potencializados pelos processos de tomada de decisão, nos quais a própria sociedade se coloca no papel de fabricante de novos riscos.

Justificadamente, o surgimento de novos riscos traz consigo o sentimento de insegurança, que decorre de forma direta de uma constatação desconcertante aos anseios modernos: os efeitos secundários não podem ser apriorísticamente afastados de forma absoluta, mas tão somente minorados diante de um controle de suas causas. Na hipótese de produção em massa de determinado produto, por exemplo, evidentemente, a escala adequada, dimensionada a esse tipo de produção, não permite o total e irrestrito

${ }^{6}$ BECK, Ulrich. A reinvenção da política: rumo a uma teoria da modernização reflexiva. In: BECK, Ulrich; GIDDENS, Anthony; LASH, Scott. Modernização reflexive: política, tradição e estética na ordem social moderna. São Paulo: Ed. da UNESP, 1997.

${ }^{7}$ GIDDENS, Anthony. Risco, confiança, reflexividade. In: BECK, Ulrich; GIDDENS, Anthony; LASH, Scott. op. cit.

${ }^{8}$ LASH, Scott. A reflexividade e seus duplos: estrutura, estética e comunidade. In: BECK, Ulrich; GIDDENS, Anthony; LASH, Scott. Modernização reflexive: política, tradição e estética na ordem social moderna. São Paulo: Ed. da UNESP, 1997.

${ }^{9}$ Nesse sentido, esclarece BECK que "El proceso de modernización se vuelve reflexivo, se toma a sí mismo como tema y problema. Las cuestiones del desarrollo y de la aplicación de tecnologías (en el ámbito de la natureza, la sociedade y la personalidad) son sustituidas por cuestiones de la gestión política y científica (administración, descubrimiento, inclusión, evitación y ocultación) de los riesgos de tecnologías a aplicar actual o potencialmente em relación a horizontes de relevancia a definir especialmente." BECK, Ulrich. $L a$ sociedad del riesgo: hacia una nueva modernidad, cit., p. 30.

${ }^{10}$ INCERTEZAS fabricadas. Entrevista com o sociólogo alemão, Ulrich Beck. Disponível em: $<$ http://amaivos.uol.com.br/amaivos09/noticia/noticia.asp?cod_noticia=7063\&cod_canal=41>. Acesso em: 14 fev. 2010. 
afastamento dos riscos, decorrentes de falhas técnicas inerentes ao desenvolvimento do produto em tais condições, mas possibilita, certamente, que os perigos daí provenientes sejam diminuídos, por meio da implementação de um controle efetivo de cada uma das fases de produção.

Os sobreditos novos riscos são caracterizados, centralmente, pela ubiquidade, vale dizer, pela sua permanência no tempo, de modo que se iniciam no passado, existindo atualmente e necessariamente perdurando no futuro. A configuração dos riscos nestes termos assume feições ainda mais claras nos casos em que se faz imperativa a deflagração do procedimento de recall. Nesta hipótese, por mais efetivo que tal mecanismo se apresente e concretize, ainda que a empresa cumpra corretamente todas as regras determinantes do recall, jamais será plenamente capaz de resgatar todas as unidades de produtos defeituosos do mercado de consumo. O recall, desta maneira, cumprirá a tarefa de minorar os riscos, mas não será capaz de afastar definitivamente o perigo que os produtos defeituosos remanescentes continuarão representando aos consumidores ao longo de um período indeterminável.

Além da ubiquidade, os efeitos secundários podem ser caracterizados pela glocalidade $^{11}$. Isso quer dizer que as consequências da realização dos riscos podem atingir não apenas as regiões locais, ou seja, aquelas geograficamente próximas da região onde foram produzidos, mas, conservam, ainda, o potencial de alcançar escalas globais. Ou seja, a esfera de produção de efeitos lesivos dos novos riscos alcança, simultaneamente, as dimensões global e local. Por tal razão, qualquer tentativa de eliminar por completo as consequências seria fadada ao fracasso, tendo em vista que se torna humanamente impossível estabelecer um cálculo exato, tanto no que se refere à quantidade de pessoas que seriam afetadas, quanto ao estabelecimento de sua localização ${ }^{12}$.

\footnotetext{
${ }^{11}$ O sociólogo ROLAND ROBERTSON, que se dedica ao estudo do fenômeno da globalização, é o primeiro autor a utilizar a expressão "glocal", com o intuito de fundir os termos "global" e "local". ROBERTSON, Roland. Globalization: time-space and homogeneity-heterogeneity. In: FEATHERSTONE, Mike; LASH, Scott; ROBERTSON, Roland. Global modernities. London: Sage, 1995. p. 28.

${ }^{12} \mathrm{O}$ acidente nuclear de Chernobil, ocorrido em abril de 1986, é um exemplo das dimensões que um risco decorrente do desenvolvimento tecnológico pode atingir. O risco lá criado realizou-se durante um teste de segurança que, acidentalmente, gerou a explosão de um reator. Esta explosão liberou para a atmosfera uma nuvem radioativa que atingiu a então União Soviética (áreas da Ucrânia, Bielorússia e Rússia), a Europa Oriental, a Escandinávia, o Reino Unido e outras regiões do continente Europeu. Entende-se, hoje, que o acidente decorreu de um erro no projeto de concepção do reator da usina associado à falha no treinamento operacional dado à equipe de trabalho. Informações obtidas em: WIKIPEDIA. Disponível em:<http://ru.wikipedia.org/wiki/>.
} 
Some-se, ainda, aos elementos anteriormente expostos, duas outras importantes características acerca dos novos riscos: indetectabilidade e invisibilidade ${ }^{13}$. Os perigos tornam-se indetectáveis e invisíveis na modernidade reflexiva em virtude de sua própria natureza, vale dizer, o risco agregado aos produtos, por exemplo, só se revela no momento que concretiza seu potencial lesivo. São, neste caso, riscos inerentes ao produto, que fogem à percepção comum dos danos que pode por seu uso ou consumo provocar e, em alguns casos, até mesmo à capacidade técnica ou científica de percebê-los, devido à incapacidade das ciências naturais em aferi-los. Nesse sentido, um automóvel, por exemplo, sempre representará algum risco a quem o utilize, pois, traz inerente a ele a capacidade de criar determinados riscos, comuns a esse tipo de produto e que, justamente por serem comuns, são considerados e calculados para um manejo diligente por parte do consumidor. Entretanto, se há um risco de amputação de um dedo da mão, em decorrência de defeito de concepção do mecanismo de rebatimento do banco traseiro do automóvel, por exemplo, foge-se à legítima expectativa que se tem diante deste tipo de bem, representando, assim, um efeito secundário inesperado, indetectável e invisível até o momento em que efetivamente ocorra a lesão.

Diante deste cenário de insegurança, a sociedade acaba por colocar expectativas das mais diversas ordens no Direito e, particularmente, no Direito Penal, muitas das quais, bastante afastadas de suas reais possibilidades de alcance. Na maior parte dos casos, o ordenamento jurídico é capaz de regular as relações empresariais e consumeristas sem recorrer à esfera penal. Há casos, entretanto, que esse recurso, além de se justificar, se torna essencial à tutela social.

Certo é que, atualmente, as leis penais estão fartas de normas simbólicas ${ }^{14}$ reguladoras de situações que poderiam ser, facilmente, tuteladas por outras esferas jurídicas, antes de se pensar no instrumento estatal de regulação de conflitos ultima ratio que é o Direito Penal. O Código de Defesa do Consumidor, em sua parte penal, seguindo

\footnotetext{
${ }^{13}$ Segundo BECK, "Muchos de los nuevos riesgos (contaminaciones nucleares o químicas, sustancias nocivas en los alimentos, enfermedades civilizatorias) se sustraen por completo a la percepción humana inmediata. Al centro pasan cada vez más los peligros que a menudo para los afectados no son visibles ni perceptibles, peligros que en ciertos casos no se activan durante la vida de los afectados, sino en la de sus descendientes; se trata em todo caso de peligros que precisan de los "órganos perceptivos" de la ciencia (teorías, experimentos, instrumentos de medición) para Placerse "visibles”, interpretables, como peligros. El paradigma de estos peligros son las mutaciones genéticas causadas por la radiactividad, que, imperceptibles para los afectados, dejan a éstos por completo (tal como muestra el accidente en el reactor de Harrisburg) a la merced del juicio, de los errores, de las controvérsias de los expertos”. BECK, Ulrich. La sociedad del riesgo: hacia una nueva modernidad, cit., p. 33.

${ }^{14}$ HASSEMER, Winfried. Derecho penal simbólico y protección de bienes jurídicos. In: BUSTOS, Juan Bustos Ramirez (Dir.). Pena y Estado. Santiago: Editorial Jurídica Conosur, 1995. p. 23-36.
} 
esta tendência, trata, basicamente, de matérias que prescindiriam desta forma extrema de tutela. Também é certo que, por outro lado, há situações em que lesões a bens jurídicos individuais dos consumidores, causados por decisões tomadas por empregados e administradores de empresas, em busca de desenvolvimento e lucro sem controle, permanecem sem resposta apropriada do ordenamento jurídico, visto que as responsabilidades restam disseminadas e incertas ao longo da cadeia empresarial.

Questões de autoria e nexo de causalidade, dentre outras, tornam a tutela penal, no cenário empresarial, bastante complexa, mas não impossível nem inadequada. Para que alguém seja criminalmente responsabilizado por um resultado indesejado é fundamental, dentre outros fatores, que tenha a ele dado causa. Seguindo este raciocínio, faz-se necessário lembrar que os riscos até agora relatos, ou seja, aqueles entendidos como efeitos colaterais da modernidade, têm sua gênese nos processos de tomadas de decisão. Ou seja, ao se falar em produção e comercialização de bens de consumo, deve-se atentar para o fato de que, no seio de uma organização empresarial, alguém, em algum momento ao longo da cadeia que concebe, fabrica e coloca um produto no mercado, toma uma ou mais de uma decisão, em consequência da qual o referido produto apresentará níveis maiores ou menores de segurança considerada a legítima expectativa do consumidor final. Deve-se aferir se, ao tomar a sobredita decisão, esta pessoa agiu dentro dos parâmetros que deveria agir para garantir que o bem de consumo atenda as perspectivas de segurança daqueles que com ele terão contato.

Esta não é, certamente, uma tarefa fácil, uma vez que as empresas são organizações complexas com divisões de tarefas e responsabilidades nem sempre muito claras. Mas, as empresas não são as únicas formas constituídas de organizações complexas no âmbito das quais se pode delinquir. As organizações criminosas, bem como, a Administração Pública, também o são. Mas, ainda assim, apesar da dificuldade que há, muitas vezes, em se encontrar o responsável por um resultado delituoso dentro de uma organização complexa, o Estado não deixa de perseguir seus autores nem de ter interesse em puni-los.

Segundo WINFRIED HASSEMER e FANCISCO MUÑOZ CONDE ${ }^{15}$, embora não haja dúvidas de que há casos onde há pertinência do Direito Penal na regulação da responsabilidade pelo produto, na maioria deles, como dito anteriormente, a tutela jurídica pode ser operada por outros ramos do ordenamento jurídico. Deve-se, portanto, limitar até

\footnotetext{
${ }^{15}$ MUÑOZ CONDE, Francisco; HASSEMER, Winfried. La responsabilidad por el producto en derecho penal. alença: Tirant lo Blanch, 1995
} 
onde vai essa pertinência, observando os preceitos penais constitucionais limitadores de abusos e garantidores do Estado Democrático de Direito.

Não se busca, aqui, a defesa daquilo que se convencionou chamar de expansão do Direito Penal. Não se propõe o uso do Direito Penal para minorar a sensação de medo trazida pela nova realidade social nem sua utilização como meio de tutela de novos bens jurídicos surgidos no último século ${ }^{16}$. Mas, sua utilização para tutelar a vida e a integridade física das pessoas expostas aos efeitos das decisões tomadas por aqueles indivíduos que dentro das esferas empresariais têm a capacidade de tomada de decisão, notadamente, no que diz respeito, à colocação de produtos no mercado de consumo. É o Direito Penal com suas limitações liberais preservadas, mas, com a dificuldade de verificar o responsável pelo resultado indesejado por estar, este sujeito, camuflado no contexto empresarial. Repita-se: dificuldade não é impossibilidade.

É necessário que o Direito Penal acompanhe as evoluções sociais, e cumpra seu papel no que diz respeito à regulação fragmentária e subsidiária das relações sociais, especialmente, das relações consumeristas nas quais um ou mais indivíduos têm a capacidade, por meio de tomada de decisão, de colocar em risco, por intermédio da colocação de produtos perigosos no mercado de consumo, bens jurídicos, penalmente tutelados, de um número indefinido de pessoas.

\subsection{Insuficiência de outros ramos do Direito tutelarem a nova realidade social: o Direito Penal como ultima ratio frente à delinqüência no âmbito da empresa}

Desde a Declaração dos Direitos do Homem e do Cidadão de 1879, dentre os princípios penais que limitam a intervenção penal do Estado na sociedade, ocupam lugar de destaque aqueles que determinam que esta intervenção só se dê quando absolutamente indispensável, ou seja, apenas em caráter subsidiário, quando todos os outros recursos possíveis ao Direito já tiverem sido tentados sem sucesso ${ }^{17}$. O Direito Penal é, deste modo,

\footnotetext{
${ }^{16}$ Acerca da discussão a respeito deste tema: SILVA SÁNCHEZ, Jesus-María. A expansão do direito penal: aspectos da política criminal nas sociedades pós-industriais. Tradução de Luiz Otavio de Oliveira Rocha. São Paulo: Ed. Revista dos Tribunais, 2002. (Série as ciências criminais no século 21, v. 11).

${ }^{17}$ Declaração dos Direitos do Homem e do Cidadão, art. $8^{\circ}$ : "A lei apenas deve estabelecer penas estrita e evidentemente necessárias (...)”.
} 
a ultima ratio que deve ser utilizada de forma fragmentária, para tutelar os bens jurídicos mais relevantes à vida social contra lesões significativas, com alto grau de ofensividade ${ }^{18}$.

Seguindo esta mesma linha de raciocínio, as atuações praticadas no âmbito das empresas, somente devem ser reguladas pelo Direito Penal quando os outros ramos do Direito não conseguirem desestimular suficientemente aquelas que prejudiquem o livre desenvolvimento da sociedade e dos indivíduos ${ }^{19}$, por serem perigosas ou lesivas a bens jurídicos de terceiros.

A criminalidade na seara empresarial é fenômeno relativamente novo. Trata-se de característica da modernidade, que, nos dias atuais, diante da capacidade de imposição dos chamados novos riscos pela prática da atividade empresária, cada vez mais complexa, só tende a crescer, visto que, há clara tendência legislativa à implementação do fenômeno conhecido como expansão do direito penal, em que o legislador crê que, senão a única, a mais eficiente forma de regulação de conflitos sociais se dá por meio da criminalização de condutas antes atípicas ou do aumento de pena cominada aos crimes já existentes ${ }^{20}$.

As sociedades empresárias têm como objeto a produção e distribuição de riquezas, não tendo se preparado, no entanto, para um adequado tratamento dos riscos e efeitos colaterais decorrentes desta atividade ${ }^{21}$. O desenvolvimento científico e tecnológico e seus, inicialmente, imprevisíveis reflexos perigosos e danosos ao bem estar social, tornam-se peças centrais da geração de conflitos na sociedade e dúvidas a respeito de seu tratamento jurídico, em especial, naquilo que diz respeito à esfera penal, surgem naturalmente.

Sendo a principal finalidade da empresa a busca pelo lucro, nos casos em que haja conflito entre os valores financeiro e segurança social, os indivíduos que a dirigem podem, decidir priorizar o primeiro em detrimento do segundo. Dito de outro modo, numa empresa fornecedora de determinado produto, por exemplo, ao se depararem com uma situação na qual, para que seja preservada a segurança da população, terá que se arcar, como

\footnotetext{
${ }^{18}$ REALE JÚNIOR, Miguel. Instituições de direito penal: parte geral. Rio de Janeiro: Forense, 2002. v. 1, p. 25.

${ }^{19}$ ROXIN, Claus. Derecho penal: parte general. Trad. da 2. ed. alemã: Diego-Manuel Luzón Pena, Miguel Diaz y Garcia e Javier de Vicente Remsal. Madrid: Civitas, 1997. t. 1, p. 56.

20،....realmente, não é nada difícil constatar a existência de uma tendência claramente dominante em todas as legislações no sentido da introdução de novos tipos penais, assim como um agravamento dos já existentes (...) Criação de novos bens jurídico-penais", ampliação dos espaços de riscos jurídico-penalmente relevantes, flexibilização das regras de imputação e relativização dos princípios político-criminais de garantia, não seriam mais do que aspectos dessa tendência geral, à qual cabe referir-se com o termo “expansão". SILVA SÁNCHEZ, Jesus-María. op. cit., p. 21.

${ }^{21}$ AMARAL, Cláudio do Prado. Bases teóricas da ciência penal contemporânea: dogmática, missão do direito penal e política criminal na sociedade de risco. São Paulo: IBCCRIM, 2007. p. 71.
} 
consequência, com prejuízo financeiro, seus dirigentes podem optar pela evitação do prejuízo, impondo, desta forma, perigo aos consumidores do referido produto.

É fundamental, neste sentido, que haja instrumentos estatais que sejam aptos a tutelar a sociedade diante da possibilidade de tais abusos. A responsabilidade civil e administrativa, muitas vezes, não é suficiente a esta tutela. Ambas podem gerar prejuízos aos consumidores e não às empresas e, menos ainda, àqueles que, em seu cenário, têm a capacidade de tomada de decisão e que são, na verdade, os responsáveis pela prática indesejada.

TERESA ANCONA LOPEZ lembra que a responsabilidade civil está ligada a um sistema econômico de produção. Assevera a civilista: "Não adianta apenar severamente os produtores, pois, ou eles irão à falência ou, então, o seguro de responsabilidade civil cobrirá os danos, mas haverá repasse para os produtos e serviços, e quem pagará será o consumidor final"22. Ou seja, sendo possível calcular que, em decorrência da colocação de determinado produto perigoso no mercado consumerista, um número de acidentes de consumo provavelmente ocorrerá e, como consequência, gerará a demanda de ações de responsabilidade civil contra a empresa que o produziu ou o comercializou, há a possibilidade de que o valor do prejuízo daí decorrente ser calculado e, consequentemente, integralmente repassado para o preço final do produto, embutido em uma fatia de seu orçamento. Neste sentido, conclui ANCONA LOPEZ: "Em um sistema capitalista, o direito da responsabilidade está na dependência de fatores econômicos. O fato de o Estado forçar essa ou aquela medida protecionista vai acabar por prejudicar seus protegidos" ${ }^{23}$.

Deste modo, não sendo possível a outras esferas do Direito, desestimularem a imposição de riscos à população além de sua legítima expectativa de segurança, não se pode entender, ser o uso do Direito Penal precipitado nem inadequado. Respeita-se, portanto, o Princípio da Subsidiariedade, sendo pleiteada a utilização do Direito Penal como ultima ratio, ou seja, como o último recurso disponível pelo Estado para a resolução de conflitos e tutela social.

Embora muitas vezes, haja a capacidade por parte da tutela administrativa e civil de regular os conflitos que venham a surgir no âmbito empresarial, elas nem sempre são suficientes. Não é em todas as situações, portanto, que a criminalização de conduta

\footnotetext{
${ }^{22}$ LOPEZ, Teresa Ancona. Princípio da precaução e evolução da responsabilidade civil. 2008. Tese (Titular de Direito Civil) - Faculdade de Direito, Universidade de São Paulo, São Paulo, 2008. p. 8.

${ }^{23}$ Id., loc. cit.
} 
praticada no âmbito da empresa deve ser entendida como equivocada. Se há novos cenários para a atuação dos indivíduos em uma sociedade, naturalmente, haverá, neste novo local, a prática delituosa. Ainda com mais razão isso ocorre quando há a possibilidade de que, a partir deste novo espaço de atuação social, grandes riscos possam vir a ser e sejam impostos aos cidadãos.

Deve-se, no entanto, tomar cuidado para que a tutela social frente aos novos riscos impostos pelo incremento tecnológico não acabe gerando uma retração das atividades econômicas. É necessário que se encontre um meio termo entre a proteção da sociedade e a liberdade de atuação econômica empresarial. Caso contrário, os empresários podem acabar evitando atuar em determinadas áreas que possam vir a gerar riscos e, consequentemente, as gravíssimas respostas do Direito Penal $^{24}$. Ou seja, a criminalização de condutas na seara empresarial não pode engessar a atividade empresária, mas, apenas, desestimular os abusos que ali possam vir a ocorrer. Se o legislativo entender como criminalizável toda e qualquer conduta com capacidade lesiva que possa ser praticada dentro da cadeia empresarial, haverá uma evasão de disponibilidade de recursos financeiros e humanos do setor.

Naquilo que se refere à resposta dada pelo ordenamento jurídico frente à colocação de produtos defeituosos no mercado de consumo, as tutelas civil e administrativa se mostram, na concretização do Direito brasileiro, incapazes de desestimular o fornecedor à fabricar ou comercializar produtos que sejam aptos a causar dano à saúde, integridade física e vida dos consumidores, diante da possibilidade que venham a ter de gerar lucro. Seja pelo constante desrespeito às regras exaradas pela administração pública, especialmente, em razão da falta de critérios garantidores de segurança na concessão de licenças ${ }^{25}$, ou ainda pela deficiência na fiscalização dos produtos já licenciados; seja pelos valores insignificantes impostos pelo judiciário para o pagamento de indenizações por responsabilidade civil por acidente de consumo, o fato é que a colocação ou a manutenção de um produto lucrativo porém perigoso no mercado de consumo, diante de sua alternativa, ou seja, a retirada do produto do mercado e consequente cessação de lucros, é uma opção

\footnotetext{
${ }^{24}$ BOTTINI, Pierpaolo Cruz. Crimes de perigo abstrato. 2. ed. rev. e atual. São Paulo: Ed. Revista dos Tribunais, 2010. p. 63.

${ }^{25}$ A Anvisa, por exemplo, determina na Resolução no. 23 de 15 de março de 2000 (que trata do Manual de Procedimentos Básicos para registro e dispensa da obrigatoriedade de produtos pertinentes à área de alimentos), que sejam apresentados pela empresa solicitante, uma série de documentos ali elencados ( item 5.2.3), bem como, que seja paga uma taxa (5.2.6). No entanto, a agência não testa preventivamente os produtos para os quais são solicitadas os registros, limitando-se, apenas, à análise de documentação fornecida pela empresa interessada.
} 
eventualmente adotada pelos indivíduos que atuam empresarialmente e que, sendo assim, respeitam a lógica do mercado.

A falta de resposta proporcional diante deste abuso acaba por gerar o entendimento de que a opção escolhida com base em critérios estritamente econômicos é a mais conveniente empresarialmente. Assim, um produto, por exemplo, que tenha a projeção de gerar para determinada empresa um lucro de $\mathrm{R} \$ 10.000 .000,00$, mas, que traga a ele agregada a possibilidade de casar dano à integridade física do consumidor, capaz de determinar um prejuízo decorrente de responsabilidade civil da ordem de $\mathrm{R} \$ 1.000 .000,00$, pode ser entendido como ótima opção de investimento, ainda que considerados eventuais danos à imagem da empresa.

Delitos podem, portanto, ser cometidos na seara empresarial, por aqueles indivíduos que ali atuam. É evidente que, tratando-se a atividade empresarial de atividade econômica e que, portanto, visa o lucro, o crime cometido em seu cenário será, via de regra, de caráter econômico. As empresas que se refere a empresas fornecedoras de produtos e prestadoras de serviços no âmbito das relações de consumo não são exceção a esta regra.

Naquilo que se refere a empresas cujo objeto é fornecimento de produtos e prestação de serviços, a possibilidade da prática delituosa por indivíduos que nelas atuem, ganha contornos específicos, notadamente, no que concerne à imposição de riscos à saúde, integridade e vida dos consumidores que extrapolem os limites do risco permitido e que, por isso, sejam inesperados e incalculáveis.

Ao entrar em um avião, por exemplo, imagina-se que os empregados da companhia aérea responsáveis pela manutenção da aeronave tenham realizado adequadamente seu trabalho, isentando os passageiros de riscos extras, ou seja, riscos além daqueles legitimamente por eles esperados. Trata-se de clara manifestação do Princípio da Confiança $^{26}$, segundo o qual se entende, conforme LUÍS GRECO, que "ninguém, ao agir, precisa preocupar-se com a possibilidade de que outra pessoa possa se comportar erradamente e com isso concorrer para a produção de um resultado indesejado. Pode-se, em regra, confiar que os demais se comportarão de modo correto" ${ }^{27}$. Podem, no entanto, ocorrer casos em que as regras que devem ser observadas para que se tenha a certeza de que a aeronave está em plenas condições de voar em segurança, não tenham sido

\footnotetext{
${ }^{26}$ Este Princípio está explicado com maior detalhamento no Capítulo 3, item 3.3.1.

${ }^{27}$ GRECO, Luís. Um panorama da teoria da imputação objetiva. Rio de Janeiro: Lumen Juris, 2005. p. 53.
} 
cumpridas pelo indivíduo responsável por realizar esta função, criando, deste modo, uma gama de riscos imprevisíveis aos consumidores da referida prestação de serviço de transporte aéreo. Ou seja, ainda que seja certo que todos aqueles que se utilizam deste meio de transporte estejam cientes da existência de riscos inerentes a esta atividade e, ainda assim, optem, livre e conscientemente, por sua utilização, ainda mais certo é que nem todos continuariam optando se soubessem que a inspeção de segurança que esperam, confiantemente, que esteja sendo cumprida de forma rigorosa pela companhia aérea em conformidade com as normas de segurança reguladoras do setor, esteja sendo negligenciada.

Seguindo esta linha de raciocínio, pode-se dizer que a colocação de produtos defeituosos no mercado de consumo, pode ter, muitas vezes, motivação econômica, podendo ser deflagrada por uma série de fatores: seja pela escolha de matéria prima inadequada em consequência de minoração de custos orçamentários; seja em razão de opção por colocar no mercado de consumo produto cujo desenvolvimento tenha sido altamente dispendioso e, ainda que ao final dos testes de segurança tenha se percebido sua vocação para a causação de lesão a bem jurídico do consumidor, tenha se optado pela não descontinuidade de sua comercialização em decorrência de alta expectativa de lucro, favorável à empresa; seja por qualquer outra razão econômica.

Na relação de consumo, a vulnerabilidade do consumidor deve nortear toda a prática empresarial, limitando as decisões tomadas. Deste modo, o lucro, finalidade da atividade empresarial, deve ser perseguido, tendo, porém, como baliza constante, o direito do consumidor a ser protegido contra riscos existentes que estejam além daquele que ele pode ter conhecimento. Inclusive, pois, só assim, tendo consciência da existência do risco é que o consumidor poderá optar livremente por corrê-lo. Portanto, a opção por correr ou não o risco pelo consumo de um produto deve ser daquele que irá corrê-lo, ou seja, o consumidor, e não do fornecedor que pode vir a impô-lo, sem qualquer forma de previsibilidade e escolha por parte do consumidor. Isso, porém, nem sempre acontece, correndo consumidor riscos por ele desconhecidos e imprevisíveis e, muitas vezes, sabidos e, até, economicamente calculados, pelo fornecedor.

Entende-se, portanto, que o Direito Penal é um instrumento estatal adequado e, eventualmente, necessário à proteção social frente a atuação de indivíduos que atuem no cenário empresarial, notadamente, no âmbito das relações de consumo, produzindo e fazendo circular produtos no mercado, eventualmente, perigosos. 


\subsection{Perigo e a necessidade de sua criminalização. A antecipação do resultado delituoso}

Conforme lição de MIGUEL REALE JÚNIOR ${ }^{28}$, perigo $^{29}$ pode ser conceituado por intermédio de três teorias. Para a teoria subjetiva o perigo não encontra lugar na realidade, trata-se de mera representação mental do homem, originada em sua angústia existencial advinda de lacuna existente em seu conhecimento, que acaba por gerar um mal-estar relativo a um futuro incerto ${ }^{30}$. A teoria objetivista, de outro modo, conceitua o perigo como a possibilidade objetiva de realização de dano, que pode não vir a se realizar, em decorrência de condições supervenientes. Uma terceira teoria, desenvolvida por ROCCO, mitiga as teorias anteriores entendendo perigo como "a possibilidade de um dano e dano é a diminuição de um bem ou o sacrifício e restrição de um interesse" ${ }^{31}$.

Enquanto os riscos tradicionais tinham o potencial de afetar realidades bem definidas em termos temporais e espaciais, como efeitos da modernidade reflexiva, os riscos ganham novos significados, deixando de ser limitados temporal e espacialmente, ganhando a capacidade de transposição de fronteiras e permanência no tempo. Diante desta nova realidade busca-se por intermédio de diversas áreas do conhecimento humano, dentre as quais o Direito ocupa lugar destacado, o desestímulo a condutas que venham a criar novos riscos, bem como, a minimização de suas consequências indesejadas.

Neste panorama o Direito Penal ocupa posição relevante visto que o conceito de perigo, constantemente, traz a si inerente uma relação com a probabilidade de lesão a bem jurídico $^{32}$. Não sem motivo, as questões relativas à possibilidade e à legitimidade de antecipação do resultado delitivo a momento anterior à efetiva lesão ao bem jurídico, vem sendo bastante discutida na doutrina jurídico-penal contemporânea, dando origem a uma série de possíveis soluções ao referido problema.

Os delitos, conforme os efeitos da conduta que incidam no bem jurídico tutelado devam ser danosos ou, apenas, de colocação de sua integridade em perigo, podem ser classificados em delitos de dano ou delitos de perigo. Segundo ROXIN, para que haja

\footnotetext{
${ }^{28}$ REALE JÚNIOR, Miguel. op. cit., v. 1, p. 159-161.

${ }^{29}$ Os termos risco e perigo são utilizados, nesse contexto, como expressões sinônimas.

${ }^{30}$ JAPIASSÚ, Hilton; MARCONDES, Danilo. Dicionário básico de filosofia. 4. ed. atual. Rio de Janeiro: Jorge Zahar, 2006. p. 9.

${ }^{31}$ REALE JÚNIOR, Miguel. op. cit., v. 1, p. 160.

${ }^{32}$ KINDHÄUSER, Urs. Estructura e legitimación de los delitos de peligro del derecho penal. Revista para el Análisis del Derecho, Barcelona, p. 3, 2009.
} 
consumação, nos crimes de dano, objeto da ação do tipo deve ser efetivamente lesionado (por exemplo, os crime de homicídio e lesão corporal, artigos $121^{33}$ e $129^{34}$ do Código Penal, respectivamente). De outro modo, no caso dos crimes de perigo, a mera suposição da ameaça mais ou menos intensa ao objeto material já é suficiente à consumação ${ }^{35}$ (como é o caso do crime de perigo de contágio venério, tipificado no art. $130^{36}$ do $\mathrm{CP}$ ).

Perigo é conceituado por MIGUEL REALE JÚNIOR, como “a aptidão, a idoneidade ou a potencialidade de um fenômeno de ser causa de um dano, ou seja, é a modificação de um estado verificado no mundo exterior com a potencialidade de produzir a perda ou a diminuição de um bem, o sacrifício ou a restrição de um interesse" ${ }^{37}$. Os crimes de perigo podem ser divididos de diversas formas, sendo a mais relavante, aquela que os separa entre crimes de perigo concreto e crimes de perigo abstrato ${ }^{38}$.

No caso dos crimes de perigo concreto, a consumação depende de que o objeto material tenha, efetivamente, sido exposto a perigo, sendo a não realização do perigo no resultado, considerada uma casualidade. Para KINDHÄUSER, há perigo concreto quando o bem jurídico é colocado em uma situação na qual a não ocorrência do dano depende apenas de mero acaso ${ }^{39}$.

Há, neste caso, a necessidade de comprovação de que o comportamento do autor criou efetivo perigo para o objeto material do delito. (por exemplo, o crime de perigo para a vida ou saúde de outrem, art. $132^{40}, \mathrm{CP}$, que é consumado no momento em que se realiza a conduta que tenha a capacidade de gerar perigo à vida ou à saúde - objetos materiais - da vítima). Por outro lado, no que se refere aos crimes de perigo abstrato, não há a necessidade de efetiva criação do perigo, sendo suficiente, a realização da conduta tipicamente descrita (é exemplo o art. $306^{41}$ do Código de Trânsito Brasileiro).

Os crimes de perigo concreto, como já dito, reclamam, para sua consumação, a efetiva colocação do objeto da ação em perigo. Tratam-se, portanto, de delitos de

\footnotetext{
${ }^{33} \mathrm{CP}$, art 121. Matar alguém.

${ }^{34} \mathrm{CP}$, art. 129: Ofender a integridade corporal ou a saúde de outrem.

${ }^{35}$ ROXIN, Claus. op. cit., p. 335-336.

${ }^{36} \mathrm{CP}$, art. 130 - Expor alguém, por meio de relações sexuais ou qualquer ato libidinoso, a contágio de moléstia venérea, de que sabe ou deve saber que está contaminado.

${ }^{37}$ REALE JÚNIOR, Miguel. op. cit., v. 1, p. 160.

${ }^{38}$ KINDH ÄUSER, Urs. op. cit., p. 3.

${ }^{39}$ Id. Ibid., p. 15.

${ }^{40} \mathrm{CP}$, art. 132 - Expor a vida ou a saúde de outrem a perigo direto e iminente

${ }^{41}$ CTB, art. 306. Conduzir veículo automotor, na via pública, estando com concentração de álcool por litro de sangue igual ou superior a 6 (seis) decigramas, ou sob a influência de qualquer outra substância psicoativa que determine dependência
} 
resultado, ou seja, há a necessidade da presença de um resultado para sua consumação. No caso, o resultado necessário à consumação, é o efetivo perigo, ou seja, há a necessidade da presença de um risco real de que o objeto material do delito seja lesionado. É, evidente, que o risco aqui referido, diz respeito ao risco não permitido ${ }^{42}$. ROXIN explica que este perigo, conforme os critérios de imputação, deve ser comprovado por meio de um prognóstico ex ante a $^{43}$.

Conforme extensa explicação de ROXIN, por ser difícil a verificação de se e quando o objeto material correu risco efetivo de sofrer uma lesão, a doutrina alemã criou diversas teorias a este respeito, dentre as quais, destacam-se: a teoria científico-natural do resultado de perigo (HORN); a teoria normativa do resultado de perigo $\left(\mathrm{SCHÜNEMANN}^{44}\right)$; a teoria normativa modificada do resultado de perigo (WOLTER);

A teoria cientírico-natural do resultado de perigo apresenta um conceito bastante limitado de perigo concreto, entendendo estar ele presente somente quando houver uma circunstância na qual, conforme o que se conhece das leis causais, poderia-se esperar um resultado lesivo sobre o objeto material que acaba não ocorrendo por uma casualidade, que entende como razões inexplicáveis pelas ciências naturais, "como que por milagre". A teoria normativa do resultado de perigo também se baseia na premissa de que o resultado lesivo só não ocorreu por uma casualidade, percebendo, no entanto, como tal, uma circunstância explicável pelas ciências naturais, porém de ocorrência improvável. A teoria normativa modificada, por sua vez, determina que todas as circunstâncias possíveis à salvação excluam o perigo concreto, daí incluídas habilidades excepcionais da pessoa posta em perigo. Deve-se observar, segundo ROXIN, que a referida habilidade é tão imprevisível para o autor quanto qualquer outra circunstância extraordinária ${ }^{45}$.

Acertada parece a concepção de KINDHÄUSER segundo a qual haverá a presença de perigo concreto quando, devido à relevância danosa de uma conduta não for possível intervir finalisticamente em um evento para evitar o dano ${ }^{46}$.

Os delitos de perigo abstrato por sua vez, preveem a punição de uma conduta em que não haja a ocorrência concreta de um resultado de perigo. O legislador, neste caso, devido ao potencial lesivo de determinadas situações sociais, notadamente, aquelas

\footnotetext{
${ }^{42}$ ROXIN, Claus. op. cit., p. 404.

${ }^{43}$ Id., loc. cit.

${ }^{44}$ Segundo Roxin, a jurisprudência alemã também apresenta pontos de partida para esta teoria. ROXIN, Claus. op. cit., p. 406.

${ }^{45}$ ROXIN, Claus. op. cit., p. 406.

${ }^{46}$ KINDHÄUSER, Urs. op. cit., p. 15.
} 
decorrentes do já referido processo de desenvolvimento tecnológico, antecipa ainda mais a consumação do resultado, procurando evitar a própria colocação do bem jurídico em perigo.

De acordo com PIERPAOLO CRUZ BOTTINI, “a expansão do direito penal atual prima pela utilização dos crimes de perigo abstrato como técnica de construção legislativa empregada para o enfrentamento dos novos contextos de risco". O autor, que afirma serem os tipos de perigo abstrato o núcleo central do chamado direito penal de risco ${ }^{47}$, elenca algumas razões para o recurso ao crime de perigo abstrato, dentre as quais destacam-se o alto potencial lesivo de determinadas atividades e produtos ${ }^{48}$ e a dificuldade em se prever ou explicar as relações causais decorrentes das novas tecnologias ${ }^{49}$.

Segundo ROXIN, além dos delitos clássicos de perigo abstrato, pode-se, ainda, falar nas seguintes modalidades: a) ações em massa (para o qual ROXIN entende ser a condução de veículos sob efeito de álcool o exemplo clássico): neste caso, ainda que seja completamente excluída a possibilidade de se concretizar a colocação em perigo ${ }^{50}$, o delito se consuma, pois decorre de uma necessidade preventiva da própria conduta e não apenas do resultado ${ }^{51}$; b) crimes com bem jurídico intermediário espiritualizado (ex: corrupção e falso testemunho): em que o desvalor da ação, por si, é a base para a punibilidade ${ }^{52}$; ) crimes de perigo abstrato-concreto: nesta modalidade, deve haver a presença de determindaos elementos da colocação em perigo que sejam aptos a provocar a lesão ao bem jurídico. Tais elementos devem ser aferidos, ex post, no caso concreto, pelo juiz ${ }^{53}$.

Diante da imensa gama de riscos aos quais os indivíduos vêm sendo expostos nas últimas décadas, as leis penais, atualmente, tornaram-se fartas de tipos de perigo, concreto ou abstrato, sendo necessários à tutela social, desde que utilizados de forma racional. Procura-se, com esse recurso, evitar não apenas a realização de resultados indesejados, mas a prática de condutas que possam vir a colocar em grande situação de perigo bens jurídicos penalmente tutelados.

\footnotetext{
${ }^{47}$ BOTTINI, Pierpaolo Cruz. op. cit., p. 119-120.

${ }^{48}$ Id. Ibid., p. 120.

${ }^{49}$ Id. Ibid., p. 121.

${ }^{50}$ Roxin exemplifica com o caso de um condutor dirigir um veículo em uma rua absolutamente isolada, inabitada. ROXIN, Claus. op. cit., p. 410.

${ }^{51}$ Id., loc. cit.

${ }^{52}$ Id. Ibid., p. 411.

${ }^{53}$ Id., loc. cit.
} 


\subsection{Norte de toda a criminalização: a teoria do bem jurídico}

O Direito Penal, ao cumprir sua parcela de responsabilidade na função estatal de tutelar a vida das pessoas e a sociedade de um modo geral, aplica, em regra, como resposta às infrações a suas normas, graves restrições à liberdade individual. Por trazer uma consequência tão gravosa, deve o Direito Penal, em um Estado Democrático de Direto, ser rigorosamente limitado. No entanto, diante dos diversos desvios de função aos quais vem sendo submetido faz-se necessário determinar um limite claro e preciso de destinação de suas normas para que elas não sejam estabelecidas irracionalmente nem de forma meramente simbólica.

WINFRIED HASSEMER, ao esclarecer que o Direito Penal sempre apresenta uma vertente simbólica, explica que as normas penais apresentam funções manifestas e latentes. Por funções manifestas são entendidas as condições objetivas de realização da norma, ou seja, a regulação dos casos concretos que se subsumem ao tipo abstratamente previsto, tutelando, assim, efetivamente, determinado bem jurídico. As funções latentes, por outro lado, são as mais diversas e vão desde o apaziguamento da população diante de alguma situação desestabilizadora da paz social até a demonstração de força por parte do Estado ${ }^{54}$.

O Direito Penal moderno é caracteristicamente discrepante no que concerne a suas funções manifestas e latentes e, deste modo, não seria este o elemento que faria do Direito Penal Simbólico, negativo. Haveria, portanto, a necessidade da presença de outro critério de desvalorização. Este critério seria uma qualidade objetiva da norma penal apontada como um "elemento de engano", uma oposição entre aparência e realidade ${ }^{55}$. O Direito Penal meramente simbólico, para HASSEMER, é aquele no qual as funções latentes predominam sobre as manifestas, ou seja, aquele presente nos casos em que a norma não é efetivamente capaz de alcançar os objetivos declarados de proteção de bens jurídicos, mas outros diversos. Há casos, inclusive, nos quais sequer se pretende que a norma chegue a ser, de fato, aplicada ${ }^{56}$. É necessário, deste modo, que para que um comportamento seja criminalizado, haja critérios além da mera vontade do legislador ${ }^{57}$.

\footnotetext{
${ }^{54}$ HASSEMER, Winfried. op. cit., p. 24.

${ }^{55}$ Id. Ibid., p. 29.

${ }^{56}$ Id. Ibid.

${ }^{57}$ ROXIN, Claus. A proteção de bens jurídicos como função do direito penal. Org. e trad. André Luís Callegari e Nereu José Giacomolli. 2. ed. Porto Alegre: Livraria do Advogado, 2009. p. 11.
} 
Para evitar a presença de normas em que funções latentes prevaleçam, faz-se necessária a estrita observação de determinados parâmetros, a fim de que sejam evitados desvios de função da norma penal. É imperativo, para tal, que haja uma medida entre o poder de intervenção do Estado e a liberdade dos cidadãos ${ }^{58}$.

Após as conquistas liberais da Revolução Francesa, a preocupação com uma imposição de limites à intervenção do jus puniendi estatal voltou a aumentou substancialmente, no século XX, em particular, na Alemanha que, após as atrocidades ocorridas durante a Segunda Guerra Mundial, acabou por promover ampla reforma no Direito Penal, passando a limitar a intervenção punitiva do Estado pela Teoria do Bem Jurídico $^{59}$. A partir desta teoria, que determina que a intervenção penal deva ser restrita à proteção dos bens jurídicos mais importantes ao livre desenvolvimento do indivíduo e da vida em sociedade, excluem-se da possibilidade de criminalização as convicções políticas, morais e religiosas, bem como, as condições existenciais ${ }^{60}$. A Teoria do Bem Jurídico, neste sentido, parece uma baliza essencial a esta necessária limitação destinada, em um primeiro momento, ao legislador e, posteriormente, ao magistrado.

O bem jurídico, conceituado como um "valor da vida social reconhecido pelo Direito" ${ }^{61}$, apresenta, segundo LUIZ REGIS PRADO diversas funções, sendo as mais importantes ${ }^{62}$ :

a) função de garantia: limitar o jus puniendi estatal, agindo como baliza à atuação do legislador na produção de normas penais incriminadoras, circunscrevendo-as às graves condutas capazes de causar lesão ou colocar em perigo os bens jurídicos mais importantes ao correto funcionamento da vida em sociedade;

b) função teleológica: condicionar a interpretação do tipo penal à sua finalidade, ou seja, entender seu sentido e seu alcance direcionados à proteção de determinado bem jurídico;

c) função individualizadora: verificar, no momento da fixação da pena, a gravidade da lesão ou do perigo ao bem jurídico, levando este critério em consideração;

\footnotetext{
${ }^{58}$ ROXIN, Claus. A proteção de bens jurídicos como função do direito penal, cit., p. 17.

${ }^{59}$ Id. Ibid., p. 12.

${ }^{60}$ Id. Ibid., p. 12-13.

${ }^{61}$ WARAT, Luiz Alberto. Introdução geral ao direito: interpretação da lei: temas para uma reformulação. Porto Alegre: Sergio Antonio Fabris, 1994. v. 1, p. 195.

${ }^{62}$ PRADO, Luiz Regis. Bem jurídico-penal e Constituição. 4. ed. São Paulo: Ed. Revista dos Tribunais, 2009. p. 50-51.
} 
d) função sistemática: classificar os grupos de tipos da Parte Especial do Código Penal, uma vez que se coligam de acordo com o bem jurídico que objetivam proteger.

O conceito de bem jurídico pode ser avaliado a partir de uma vertente dogmática ou de uma vertente político-criminal. A primeira tem sua base nas formulações de Binding e serve de parâmetro de interpretação teleológica da norma. $\mathrm{O}$ autor entende o bem jurídico como uma criação legislativa e o define como aquilo que a norma protege. $\mathrm{O}$ conceito de bem jurídico, deste modo, estaria implícito em qualquer norma vigente. A segunda vertente, por outro lado, vai além do direito positivo e entende como ilegítimos os tipos penais que não protejam nenhum bem jurídico ${ }^{63}$.

Deve-se procurar um ponto de apoio superior ou externo à norma penal para formular o conceito de bem jurídico. Não se pode recorrer à própria norma, pois o conceito deve servir de parâmetro crítico à lei. O texto constitucional, neste sentido, parece ser a fonte referencial mais adequada.

A Constituição como fundamento do conceito político-criminal de bem jurídico é a caminho mais comumente encontrado na doutrina ${ }^{64}$, mas, suscita algumas questões. LUÍS GRECO aponta duas, que devem ser observadas com suas respectivas respostas: um problema de demarcação e um problema da relação específica com a Constituição ${ }^{65}$. O problema de demarcação diz respeito a quais valores protegidos constitucionalmente devem ser merecedores de dignidade penal, uma vez que nossa Constituição traz elencados diversos dispositivos que não tratam de matéria propriamente constitucional. O outro problema se resume na determinação do significado de fundamentação constitucional, ou seja, de se estabelecer se para se entender um bem jurídico como constitucionalmente fundamentado, ele deve, necessariamente, estar previsto de forma expressa na Carta Magna ou se a mera não-incompatibilidade já seria suficiente.

Como resposta ao primeiro problema levantado, GRECO sugere que "o bem penalmente protegido tem de ser de relevância fundamental" e conclui que, aplicado este

\footnotetext{
${ }^{63}$ GRECO, Luís. Breves reflexões sobre os princípios da proteção de bens jurídicos e da subsidiariedade no direito penal. Revista Jurídica do Ministério Público de Mato Grosso, Cuiabá, v. 2, n. 3, p. 252, jul./dez. 2007.

${ }^{64}$ Neste sentido, Luiz Regis Prado assevera: "O conceito de bem jurídico deve ser inferido na Constituição, operando-se uma espécie de normativização das diretivas político-criminais”. PRADO, Luiz Regis. Bem jurídico-penal e constituição. 4. ed. São Paulo: Revista dos Tribunais, 2009. p. 52. Jorge de Figueiredo Dias e Jesús-María Silva Sánchez, no mesmo sentido. DIAS, Jorge de Figueiredo. Questões fundamentais do direito penal revisitadas. São Paulo: Ed. Revista dos Tribunais, 1999. p. 62-82.

${ }^{65}$ Como é o caso da norma descrita no $\S 2^{\circ}$ do artigo 242 que assevera que "o Colégio Pedro II, localizado na cidade do Rio de Janeiro, será mantido na órbita federal". GRECO, Luís. Breves reflexões sobre os princípios da proteção de bens jurídicos e da subsidiariedade no direito penal, cit., p. 254.
} 
filtro, estariam excluídas uma série de normas que não tratassem de matéria constitucional $^{66}$. E, em relação ao problema da relação específica com a Constituição, entende que a compatibilidade com os princípios constitucionais seria solução suficiente, sendo despicienda a compatibilidade com o texto expresso ${ }^{67}$.

Para a vasta maioria da doutrina ${ }^{68}$, a principal, senão a única ${ }^{69}$, finalidade do Direito Penal é a proteção dos bens indispensáveis ao convívio do homem em sociedade ${ }^{70}$. O Princípio da proteção de bens jurídicos, neste sentido, determina que toda norma penal deva ter como finalidade necessária a proteção de algo que o direito considera um bem. Mas, não qualquer bem. A proteção penal apenas é justificada nos casos em que o referido bem seja qualificado, quer dizer, quando o bem for tão relevante para a vida do indivíduo ou para a vida social que sua colocação em perigo ou sua lesão sejam consideradas extremamente graves e, por isso, sejam deflagradoras da mais severa resposta dada a um ilícito jurídico, ou seja, a resposta penal. Caso contrário, a norma será ilegítima.

A compreensão da finalidade do Direito Penal como proteção de bens jurídicos, desde sua gênese, sofreu uma série de críticas. Em um momento de intensas transformações sociais, como é este que agora vivemos, por óbvio, não é diferente.

O conceito de bem jurídico tem sua origem no período do Iluminismo, quando surgem limites ao jus puniendi do Estado. JUAREZ TAVARES entende que, embora seja praticamente impossível conceituar bem jurídico ${ }^{71}$, por causa das variedades que aduz, podem ser traçadas quatro vertentes conceituais. Seriam elas as vertentes: positivista, neokantista, ontológica e funcionalista ${ }^{72}$.

A Teoria do Bem Jurídico, que determina o delito como sendo a lesão à coisa, ao bem protegido pelo Direito $^{73}$ foi, inicialmente, formulada por BIRNBAUM, em 1834, e se contrapôs a ideia de ANSELM FEUERBACH, então em voga, de que o Direito Penal tinha

\footnotetext{
${ }^{66}$ Estaria excluída uma incriminação cujo objetivo fosse proteger o bem "Colégio Pedro II", seguindo o exemplo anteriormente dado. GRECO, Luís. Breves reflexões sobre os princípios da proteção de bens jurídicos e da subsidiariedade no direito penal, cit., p. 254.

${ }^{67}$ Id. Ibid., p. 255.

${ }^{68}$ Enquanto Claus ROXIN, Bernd Schünemman e Winfried Hassemer se posicionam favoravelmente à Teria do Bem Jurídico, Hans Joachim Hirsch e Günther Jakobs se colocam de forma diversa, entendendo que a função do Direito Penal não é a proteção de bens jurídicos.

${ }^{69}$ ROXIN, Claus. A proteção de bens jurídicos como função do direito penal, cit.

${ }^{70}$ HASSEMER, Winfried; MUÑOZ CONDE, Francisco. Introducción a la criminologia y al derecho penal. Valencia: Tirant lo Blanch, 1989. p. 99-100.

${ }^{71}$ TAVARES, Juarez. Teoria do injusto penal. Belo Horizonte: Del Rey, 2000. p. 176.

${ }^{72}$ Id. Ibid., p. 177.

${ }^{73}$ JIMÉNEZ DE ASÚA, Luis. Tratado de derecho penal: el delito. 5. ed. Buenos Aires: Losada, 1965. t. 3 , p. 103.
} 
por finalidade a proteção de direitos subjetivos. De acordo com a ideia de BIRNBAUM, os crimes não lesam direitos, mas sim bens, ou seja, entidades forjadas além da ordem jurídica.

FEUERBACH desenvolveu, no final do século XVIII, um critério essencial à delimitação do Direito Penal conforme o qual, apenas seriam puníveis os comportamentos capazes de lesionar o interesse ou direito subjetivo de particular ou do Estado, socialmente danosos e, que além disso, houvesse a efetiva necessidade de imposição da pena ${ }^{74}$. Segundo esta teoria, o delito consistia na lesão de um direito de alguém sobre uma coisa. Este critério foi posto em prática pelo jurista por intermédio de seu projeto de Código Penal do Reino da Baviera de $1813^{75}$ que não criminalizava condutas contra a moral e a religião ${ }^{76}$. Embora a teoria de FEUERBACH tenha conseguido restringir o arbítrio do poder punitivo estatal ${ }^{77}$, e aí está o seu incontestável mérito, não se pode, evidentemente, limitar o delito a condutas capazes de lesar direitos subjetivos.

BIRNBAUM, então, rompe com a concepção iluminista de FEUERBACH e distingue entre a lesão a um direito subjetivo e a lesão de um bem. Publica, em 1834, um estudo que traz originalmente a ampliação da abrangência da tutela jurídico-penal para além de pessoas e coisas às quais estava limitada pela Teoria do Direito Subjetivo. Os bens jurídicos estão além do direito, não se confundem com ele e servem de fundamentação no ato de criação das figuras delitivas ${ }^{78}$. Em decorrência desta fórmula, porém, seria, novamente, possível, punir condutas lesivas à religião e à moral ${ }^{79}$.

É BINDING, um expoente da concepção positivista, quem, num momento posterior, fala, pela primeira vez em "bem jurídico". Sua abordagem parte da suposição da existência de um direito subjetivo pertencente somente ao Estado, ou seja, o direito de determinar as condutas dos particulares, cobrando o cumprimento de suas determinações. A desobediência a essas ordens seria a negação do poder público, a transgressão de um

\footnotetext{
${ }^{74}$ SILVEIRA, Renato de Mello Jorge. Direito penal supra-individual. Interesses difusos. São Paulo: Ed. Revista dos Tribunais, 2003. p. 37. (Série Ciência do Direito Penal contemporânea, v. 3).

${ }^{75}$ KINDHÄUSER, Urs. op. cit.

${ }^{77}$ SILVEIRA, Renato de Mello Jorge.op. cit., p. 39.

${ }^{77}$ Feuerbach cumpriu seu objetivo de limitar a esfera de atuação do Direito Penal quando, no Código Penal por ele elaborado, deixaram de ser punidos diversos fatos até então tidos como crimes contra Deus e, também, a moral, como, por exemplo, o ato homossexual consentido que não lesionava nenhum direito subjetivo dos envolvidos, não sendo, portanto, merecedores de pena. KINDHÄUDER. Estructura e legitimación de los delitos de peligro del Derecho penal. In: Revista para el análisis del Derecho. Barcelona, 2009. p. 06.

${ }^{78}$ URQUIZO OLAECHEA, José. El bien jurídico. Revista Peruana de Ciencias Penales, Lima, v. 3, n. 6, p.805-840, jun. 1998. p. 815.

${ }^{79}$ SILVEIRA, Renato de Mello Jorge.op. cit., p. 40.
} 
direito público exclusivamente estabelecido a favor do Estado ${ }^{80}$. O legislador, deste modo, deve estabelecer normas que protejam contra lesões e colocações em perigo tudo aquilo que for importante para uma vida saudável da comunidade jurídica. Para este autor, o Estado cria o bem jurídico ao decidir, por intermédio da edição de uma norma, proteger um valor (bem) de extrema importância para seu correto e adequado funcionamento.

JHERING, a partir daí, constroi um sistema filosófico que acaba, mais tarde, influenciando, MERKEL e VON LISZT. Estes últimos partem da filosofia jurídica de JHERING para formular suas próprias teorias ${ }^{81}$. Para MERKEL, o objeto e a natureza do delito estão na violação dos interesses expressivos ao Direito que afetam não apenas o indivíduo, mas à coletividade. Para ele, trata-se de discussão inócua saber se o objeto imediato da proteção do Direito são bens ou interesses ${ }^{82}$. VON LISZT, por sua vez, considera o bem jurídico o elemento central da teoria do delito e o afirma como o interesse juridicamente protegido $^{83}$. Diferentemente do apregoado por BINDING, na concepção de VON LISZT, o interesse que dá origem ao bem jurídico é anterior à norma que só o irá considerar em consequência de seu caráter essencial aos interesses sociais.

Já no início do século passado, sob influência do pensamento kantiano, a teoria do bem jurídico é renovada, com o nascimento da concepção neokantista que o entende como valor cultural baseado em necessidades individuais que se convertem em bens jurídicos com a percepção de que à sua subsistência é imprescindível a tutela jurídica. A noção material de bem é, então, substituída pela concepção de valor e, em consequência disso, surgem novas teorias.

Nos anos trinta do século XX, o conceito de bem jurídico perde força por ser contrário aos interesses do Nacional-Socialismo. Seus teóricos, dentre os quais EDMUND MEZGER, o criticavam por seu individualismo e liberalismo. Para Mezger, crime era toda e qualquer violação de um dever de obediência ao Estado $^{84}$. Seguindo esta orientação, não se colocavam mais limites à intervenção punitiva do poder estatal.

Após a Segunda Guerra Mundial, no entanto, retoma-se o conceito, com o objetivo de se operar significativa limitação ao poder punitivo estatal, percebendo-se que a noção de

\footnotetext{
${ }^{80}$ URQUIZO OLAECHEA, José. El bien jurídico. Revista Peruana de Ciencias Penales, Lima, v. 3, n. 6 , p.805-840, jun. 1998. P. 815.

${ }^{81}$ JIMÉNEZ DE ASÚA, Luis. op. cit., t. 3, p. 103-104.

${ }^{82}$ Id., loc. cit.

${ }^{83}$ Id. Ibid.

${ }^{84}$ MUNÕZ CONDE, Francisco. Edmund Mezger e o direito penal de seu tempo: estudos sobre o direito penal no nacional-socialismo. Tradução de Paulo César Busato. 4. ed. Rio de Janeiro: Lumen Juris, 2005. p. 80.
} 
bem jurídico-penal seria vinculada a uma garantia da pessoa humana. HANS WELZEL, neste sentido, entende bem jurídico como um bem vital do indivíduo ou da comunidade protegido juridicamente por ser um estado socialmente desejável ${ }^{85}$.

Segundo CLAUS ROXIN, o ponto alto da Teoria do Bem Jurídico acontece em 1973 com a Reforma do Direito Penal Alemão, em especial, na esfera do Direito Penal Sexual que, neste momento, descriminalizou a homossexualidade, por exemplo, não pelo fato da conduta homossexual ter passado a ser socialmente aceita, mas porque o ato homossexual consentido entre dois agentes capazes não lesiona nem coloca qualquer bem jurídico em perigo ${ }^{86}$.

No meio dos anos setenta, no entanto, o conceito de bem jurídico passa a ser invocado no sentido contrário ao da limitação do jus puniendi estatal, ou seja, para se exigir a atuação do Direito Penal na tutela dos "novos bens jurídicos" (meio ambiente, economia, consumo...). Com isso, alguns criticam o conceito e passam a duvidar de seu caráter liberal ${ }^{87}$. Deve-se observar que, conforme assevera ROXIN, “os bens jurídicos não têm uma validade infinita, preferentemente estão submetidos às mudanças dos fundamentos jurídico-constitucionais e das relações sociais" ${ }^{88}$. E, se um valor social considerado hoje como bem jurídico pode, amanhã, em decorrência do caráter dinâmico da sociedade, deixar de assim o ser, outros valores, que ontem não eram relevantes para o Direito, podem passar a representar um alto valor.

ROXIN defende um conceito de bem jurídico liberal, pessoal e crítico à legislação. Bens jurídicos, para ele, são "as circunstâncias reais dadas ou finalidades necessárias para uma vida segura e livre que garanta todos os direitos humanos e civis de cada um na sociedade ou para o funcionamento de um sistema estatal que se baseia nestes objetivos." ROXIN, neste conceito refere-se a duas situações: ao falar em "circunstâncias reais dadas", está apontando os bens jurídicos anteriores à lei, como a vida; e, ao citar as "finalidades", está tratando das situações criadas pela lei, caso das normas tributárias ${ }^{89}$.

Vale ressaltar que, o entendimento da Teoria do Bem Jurídico como um dado limitador do Direito Penal que, neste sentido, apresenta como finalidade a tutela dos bens

\footnotetext{
${ }^{85}$ WELZEL, H. Derecho penal aleman: parte general. Trad. Juan Bustos Ramírez; Sérgio Yáñez Pérez. 11. ed. Santiago de Chile: Editorial Jurídica de Chile, 1997. p. 5.

${ }^{86}$ ROXIN, Claus. A proteção de bens jurídicos como função do direito penal, cit., p. 13.

${ }^{87}$ GRECO, Luís. Breves reflexões sobre os princípios da proteção de bens jurídicos e da subsidiariedade no direito penal, cit., p. 253.

${ }^{88}$ ROXIN, Claus. A proteção de bens jurídicos como função do direito penal, cit., p. 36.

${ }^{89}$ Id. Ibid., p. 18.
} 
jurídicos mais relevantes para a vida em sociedade não é unânime. Para HANS JOACHIM HIRSCH, o conceito de bem jurídico não é um princípio capaz de limitar o Direito Penal $a$ priori, pois, somente a pena e a extensão de sua legitimidade estatal é que poderiam ser um ponto de partida para esta limitação ${ }^{90}$. GÜNTHER JAKOBS, por sua vez, entende que a imposição da pena não é capaz de recompor um bem jurídico lesionado, não sendo, portanto, possível que sua função seja a ele vinculada. Considera, por outro lado que o delito é a negação da estrutura da sociedade, consubstanciada na norma e a pena, a marginalização dessa negação, portanto, a confirmação da estrutura. JAKOBS, seguindo esta linha de raciocínio, afirma como função da pena a confirmação da configuração da sociedade $^{91}$.

ROXIN, defendendo a Teoria do Bem Jurídico como baliza necessária à edição de normas penais, entende que, para a edição de norma penal devem ser observados, dentre outros, os seguintes critérios ${ }^{92}$ :

1) As tipificações penais arbitrárias não protegem bens jurídicos: é inadmissível exigir, sob ameaça de sanção criminal, que se reverencie a um símbolo qualquer, pois, tal exigência não serve à liberdade do indivíduo em um Estado liberal nem à capacidade funcional do sistema social baseado nesses princípios.

2) As finalidades puramente ideológicas não protegem bens jurídicos: o exemplo dado por ROXIN, neste caso, é o da "manutenção da pureza do sangue alemão" na qual se baseou a proibição nacional-socialista da dita "vergonha racial" que não pode ser entendida como bem jurídico.

3) As meras imoralidades não lesionam bens jurídicos: ROXIN entende, por exemplo, que a proibição de relações homossexuais ou quaisquer outras consideradas imorais, praticadas consensualmente, entre adultos apenas restringe a liberdade dos indivíduos, além de ser supérflua e nociva à capacidade funcional do sistema social, pois estigmatiza indivíduos socialmente integrados.

\footnotetext{
${ }^{90} \mathrm{HIRSCH}$, Hans Joachim. Acerca del estado actual de la discusión sobre el concepto de bien jurídico. In: CONGRESO INTERNACIONAL. FACULTAD DE DERECHO DE LA UNED. Modernas tendencias en la ciencia del derecho penal y en la criminología. Madrid: Universidad Nacional de Educación a Distancia, 2001. p. 386.

${ }^{91}$ JAKOBS, Günther. ¿Qué protege el derecho penal: bienes jurídicos o la vigencia de la norma? Mendoza: Ediciones Jurídicas Cuyo, 2008. p. 61.

${ }^{92}$ ROXIN, Claus. Derecho penal: parte general, cit., t. 1, p. 52.
} 
O referido autor determina que a lesão a um bem jurídico seja pressuposto essencial à punibilidade, sendo este critério necessário à limitação da tutela penal. Para ele, é preciso que a embasar qualquer intervenção penal por parte do Estado haja uma função social, qual seja, a garantia de uma sociedade em paz com liberdade e segurança, sempre que outros meios político-sociais menos violentos à liberdade dos cidadãos não forem suficientes para garanti-la ${ }^{93}$. O Direito Penal e, consequentemente, o bem jurídico deve, sempre, de qualquer modo, referenciar-se na pessoa humana como segurança à liberdade do indivíduo $^{94}$. É, deste modo, basilar que seja demonstrado ser a pessoa o fundamento da proteção penal.

$\mathrm{Na}$ atual discussão doutrinária penal, um dos temas mais conturbados gira em torno da pertinência da concessão de dignidade penal a determinados bens, coletivos ou difusos, os já aludidos "novos bens jurídicos”. No Brasil, já há uma série de normas penais, acertadamente, tutelando tais bens. Sobre este movimento, assevera RENATO DE MELLO JORGE SILVEIRA:

\begin{abstract}
"Os problemas da moderna criminalidade, bem como as alterações por que tem passado o mundo nos últimos anos, impõem uma reflexão profunda. As criminalidades econômicas e ecológicas, o contrabando de drogas, as lesões constatadas em diversos consumidores por falhas em produtos industrializados são apenas algumas facetas da nova criminalidade relativa aos interesses difusos, a qual necessita de respostas outras, que não somente as tradicionais ${ }^{95}$.
\end{abstract}

É fato que o Direito Penal deva cumprir sua parcela de responsabilidade na proteção de novos interesses que vêm surgindo na sociedade, tutelando-os. Meio-ambiente, economia e relações de consumo, devem, assim, receber a especial proteção deste que é o instrumento mais radical de proteção conferido pelo Estado. Não é demais ressaltar a necessidade de que esta intervenção seja pautada em critérios de razoabilidade, proporcionalidade e, principalmente, subsidiariedade, ou seja, qualquer papel que o Direito Penal venha a exercer nesta, ou em qualquer seara, deve ser balizado pelos fundamentos que o texto constitucional lhe confere.

Neste ponto, é necessário que se faça um esclarecimento: o Código de Defesa do Consumidor, Lei $n^{\circ}$. 8.078/90 busca seu fundamento na Constituição Federal, que ordenou sua edição e que, a partir de lá, determina a defesa, não das relações de consumo, mas do

\footnotetext{
${ }^{93}$ ROXIN, Claus. A proteção de bens jurídicos como função do direito penal, cit., p. 17.

${ }^{94}$ TAVARES, Juarez. op. cit., p. 182.

${ }^{95}$ SILVEIRA, Renato de Mello Jorge.op. cit., p. 168.
} 
consumidor $^{96}$, como sujeito vulnerável na dita relação jurídica. CLÁUDIA LIMA MARQUES assevera, seguindo esta linha de pensamento, que "o CDC brasileiro não é um Código de consumo, como a consolidação legal francesa denominada Code de la Consommation, ou a italiana denominada Codice del Consumo (...) concentra-se justamente nos sujeitos de direitos, visa proteger a este sujeito, sistematiza suas normas a partir desta ideia básica de proteção de apenas um sujeito diferente da sociedade de consumo: o consumidor" ${ }^{\prime 97}$.

No que diz respeito ao fenômeno consumerista, portanto, é adequado que seja feita a distinção entre os bens jurídicos tutelados pelos diferentes diplomas normativos: enquanto a Lei $\mathrm{n}^{\circ} 8.137 / 90$ tutela, dentre outros, os crimes contra as relações de consumo, a Lei $n^{\circ} .8078 / 90$ visa à defesa, a proteção do consumidor. É, neste sentido, adequada a intervenção penal para que sejam evitados e punidos comportamentos indesejados por parte de fornecedores que afrontem tanto os direitos básicos dos consumidores taxativamente previstos no $\mathrm{CDC}$, quanto, as relações de consumo.

Ao longo deste trabalho, serão enfrentadas as hipóteses de colocações em perigo e lesões aos bens jurídicos vida, saúde e integridade física do consumidor, eventualmente, causadas pela disponibilização de produtos defeituosos ao mercado de consumo, por fornecedores (produtores ou comerciantes).

\footnotetext{
${ }^{96}$ Neste sentido, os seguintes dispositivos: CF, art. $5^{\circ}$, XXXII - o Estado promoverá, na forma da lei, a defesa do consumidor; $\mathrm{CF}$, art. 170. A ordem econômica (...) tem por fim assegurar a todos existência digna (...) observados os seguintes princípios: V- defesa do consumidor; ADCT: art. 48. O Congresso Nacional, dentro de cento e vinte dias da promulgação da Constituição, elaborará código de defesa do consumidor.

${ }^{97}$ MARQUES, Claudia Lima; BENJAMIN, Antônio Herman V.; MIRAGEM, Bruno. Comentários ao Código de Defesa do Consumidor. 3. ed. rev. atual. e ampl. São Paulo: Ed. Revista dos Tribunais, 2010. p. 65.
} 


\section{O PROTAGONISMO DAS RELAÇÕES DE CONSUMO COMO FONTE DE CONFLITOS SOCIAIS E JURÍDICOS E SUA CONSEQUENTE TUTEla PENAL. O PAPEL DO PRODUTO NESSA REALIDADE}

\subsection{O papel das relações de consumo na geração de conflitos sociais e demandas judiciais}

A proteção jurídica ao consumidor não constitui novidade do século $\mathrm{XX}$. No Código de Hamurabi, que se estima datar de cerca de 1700 a.C., já havia normas que visavam à proteção do consumidor $^{98}$. No dia 15 de março de 1962, porém, o então Presidente dos Estados Unidos da América, John Kennedy, em um discurso em Washington afirmou ter enviado ao Congresso norte-americano uma declaração - Special Message on Protecting the Consumer Interest Statement ${ }^{99}$ - na qual declarava que "somos todos consumidores" e proclamava os quatro direitos básicos do consumidor ${ }^{100}$. Este episódio é considerado historicamente como o marco inicial do Direito do Consumidor, pois teria sido a partir daí que o mundo jurídico passou a ver as relações de consumo como objeto de seu interesse ${ }^{101}$.

Após este fato, diversos documentos normativos, cogentes ou não, foram editados pela ONU, pelo Mercosul, pela União, pelos estados e pelos municípios brasileiros.

\footnotetext{
${ }^{98}$ FILOMENO, José Geraldo Brito. Manual de direitos do consumidor. São Paulo: Atlas, 2001. p. 22. Art. 235 do Código de Hamurabi: "Se um bateleiro constroi para alguém um barco e não o faz solidamente, se no mesmo ano o barco é expedido e sofre avaria, o bateleiro deverá desfazer o barco e refazê-lo solidamente à sua custa; o barco sólido ele deverá dá-lo ao proprietário".

${ }^{99}$ WOOLLEY, John T.; PETERS, Gerhard. The American Presidency Project. Santa Barbara, CA. Disponível em: <http://www.presidency.ucsb.edu/ws/?pid=9108>.

${ }^{100}$ De acordo com a Declaração dos Direitos do Consumidor, como ficou conhecida a declaração do Presidente Kennedy, todo consumidor tem: 1) Direito à segurança: devem ser protegidos contra a comercialização de produtos que são prejudiciais à saúde ou vida; 2) Direito à informação: de ser protegido contra práticas fraudulentas, enganosas ou informações grosseiramente enganosas, publicidade, rotulagem ou outras práticas, e a conhecer os fatos que precisa para fazer uma escolha consciente; 3) Direito à escolha: a ser assegurado, sempre que possível, o acesso a uma variedade de produtos e serviços a preços competitivos e nas indústrias em que a concorrência não é viável uma regulação do Governo ser substituído por uma garantia de qualidade satisfatória e serviços a preços justos.; 4) Direito a ser ouvido: para ter certeza de que os interesses do consumidor receberá a devida atenção na formulação da política do Governo, e tratamento justo e célere em seus tribunais administrativos. Disponível em: http://www.presidency.ucsb.edu/ ws/index.php?pid=9108.

${ }^{101}$ BENJAMIN, Antônio Herman V.; MARQUES, Cláudia Lima; BESSA, Leonardo Roscoe. Manual de direito do consumidor. 2. ed. rev. atual. e ampl. São Paulo: Ed. Revista dos Tribunais, 2009.
} 
Ressalta-se a importância da Carta Constitucional de 1988, que dentre outras determinações, define: em seu art. 5 XXXII, que o Estado promoverá, na forma da lei, a defesa do consumidor; em seu art. 170, V, que a ordem econômica deve observar a defesa do consumidor como princípio; e no art. 48 da ADCT, a elaboração, pelo Congresso Nacional, após cento e vinte dias da promulgação da Constituição, de um Código de Defesa do Consumidor.

Além da Constituição de 1988, destacam-se, no âmbito consumerista, a Lei nº. 8.078 de 11 de setembro de 1990 (Código de Defesa do Consumidor - CDC), que protege específica e imediatamente o consumidor; e a Lei $\mathrm{n}^{\circ} 8.137$ de 27 de dezembro de 1990, que define crimes, dentre outros, contra as relações de consumo.

Embora o CDC traga, em seu art. $6^{\circ}$, um extenso elenco dos direitos básicos dos consumidores, muitos desses direitos ainda lhes são negados seja por mera negligência, seja por interesses econômicos dos fornecedores que priorizam o lucro em detrimento da preservação dos bens jurídicos dos consumidores, tais como vida, saúde, segurança e propriedade.

\subsection{Elementos essenciais às relações consumeristas}

Relações de consumo são relações jurídicas que apresentam como sujeitos, de um lado um consumidor ( $\operatorname{art.} 2^{\circ}, \mathrm{CDC}$ ) e de outro um fornecedor ( $\operatorname{art.} 3^{\circ}, \mathrm{CDC}$ ) e têm como objeto o fornecimento indistinto no mercado de consumo de um produto (art. $3^{\circ} \S 1^{\circ}$, CDC) ou de um serviço (art. $3^{\circ} \S 2^{\circ}, \mathrm{CDC}$ ).

Dizem respeito ao tema aqui tratado, ou seja, à responsabilidade penal pelo produto: o consumidor, o fornecedor e o produto, que serão analisados a seguir.

\subsubsection{O consumidor e seus direitos}

A Lei nº 8.078/90, já em suas primeiras linhas, afirma que elenca, em seu corpo, normas de proteção e defesa do consumidor ${ }^{102}$. Este espírito defensivo-protetivo do CDC,

\footnotetext{
${ }^{102}$ Art. $1^{\circ} \mathrm{O}$ presente código estabelece normas de proteção e defesa do consumidor, de ordem pública e interesse social, nos termos dos artigos. $5^{\circ}$, inciso XXXII, 170, inciso V, da Constituição Federal e art. 48 de suas Disposições Transitórias.
} 
que pode ser percebido por meio da leitura de seus dispositivos e compreensão de seus princípios, já havia sido antecipado pela Constituição Federal.

O texto constitucional, ao referir-se ao consumidor, o coloca em posição de vulnerabilidade, sempre como alguém que faz jus à tutela do Estado de forma bastante específica $^{103}$. Isso quer dizer que a necessidade de se entender o consumidor como categoria que merece ser defendida é uma concepção constitucionalmente consagrada.

Isto decorre do fato de haver dois polos nas relações de consumo, um fornecedor e um consumidor, sendo este último menos capaz que o primeiro, no que diz respeito à capacidade econômica ou técnica, bem como, muitas vezes, no que se refere ao conhecimento a respeito daquilo que foi fornecido e será, por ele, consumido. Daí, a presença de efetiva vulnerabilidade do consumidor, especialmente, nos dias atuais em que, devido às amplas cadeias de produção e comercialização, raros são os momentos em que se tem consciência a respeito de onde e de quais condições provém o produto ou serviço que se consome.

Ao longo da Lei $\mathrm{n}^{\circ}$ 8.078/90 encontram-se normas que visam a proteger o consumidor. Não se trata de um microssistema que procure tutelar o mercado nem o consumo $^{104}$, mas designadamente, o consumidor, como sujeito mais fraco de uma relação jurídica específica. A vulnerabilidade do consumidor perante o fornecedor é expressamente reconhecida no inciso I do artigo $4^{\circ}$ do da referida lei ${ }^{105}$, que trata dos princípios observados pela Política Nacional das Relações de Consumo ${ }^{106}$.

\footnotetext{
${ }^{103}$ Em três situações a Constituição de 88 faz referência expressa à necessidade de "defesa do consumidor": ao tratar da garantia dos Direitos Fundamentais, (art. 5\%, XXXII o Estado promoverá, na forma da lei, a defesa do consumidor); ao elencar os princípios da Ordem Econômica (art. 170, V: defesa do consumidor) e, no ADCT, ao determinar a elaboração de um Código referente ao tema (art. 48. O Congresso Nacional, dentro de cento e vinte dias da promulgação da Constituição, elaborará código de defesa do consumidor).

${ }^{104}$ MARQUES, Claudia Lima; BENJAMIN, Antônio Herman V.; MIRAGEM, Bruno. Comentários ao Código de Defesa do Consumidor, cit., p. 151.

${ }^{105} \mathrm{CDC}$, art. $4^{\mathrm{o}}$, I - reconhecimento da vulnerabilidade do consumidor no mercado de consumo;

${ }^{106}$ Conforme o CDC, art. $4^{\circ}$ : A Política Nacional das Relações de Consumo tem por objetivo o atendimento das necessidades dos consumidores, o respeito à sua dignidade, saúde e segurança, a proteção de seus interesses econômicos, a melhoria da sua qualidade de vida, bem como a transparência e harmonia das relações de consumo, atendidos os seguintes princípios: I - reconhecimento da vulnerabilidade do consumidor no mercado de consumo; II - ação governamental no sentido de proteger efetivamente o consumidor: a) por iniciativa direta; b) por incentivos à criação e desenvolvimento de associações representativas; c) pela presença do Estado no mercado de consumo; d) pela garantia dos produtos e serviços com padrões adequados de qualidade, segurança, durabilidade e desempenho; III - harmonização dos interesses dos participantes das relações de consumo e compatibilização da proteção do consumidor com a necessidade de desenvolvimento econômico e tecnológico, de modo a viabilizar os princípios nos quais se funda a ordem econômica (art. 170, da Constituição Federal), sempre com base na boa-fé e equilíbrio nas relações entre consumidores e fornecedores; IV - educação e informação de fornecedores e consumidores, quanto aos seus direitos e deveres, com vistas à melhoria do mercado de consumo; V -
} 
Para HERMAN BENJAMIN, a afirmação do Princípio da Vulnerabilidade do Consumidor, mais do que um meio de garantia à igualdade formal-material dos sujeitos da relação jurídica consumerista, é o ponto de partida do microssistema consumerista ${ }^{107}$.

CLÁUDIA LIMA MARQUES, por outro lado, discorrendo sobre o tema, assevera que "a vulnerabilidade é mais um estado da pessoa, um estado inerente de risco ou um sinal de confrontação excessiva de interesses identificados no mercado, é uma situação permanente ou provisória, individual ou coletiva, que fragiliza, enfraquece o sujeito de direitos, desequilibrando a relação. A vulnerabilidade não é, pois, o fundamento das regras de proteção do sujeito mais fraco, é apenas a explicação destas regras ou da atuação do legislador." 108

Para o Código de Defesa do Consumidor, portanto, é presumida a vulnerabilidade, no que interessa ao tema em pauta, de todo aquele que adquire produto como destinatário final. Essa vulnerabilidade apresenta três vertentes: técnica, fática e científica ${ }^{109}$.

A vulnerabilidade técnica é a que se manifesta pela ausência de conhecimento específico por parte do consumidor sobre o produto ou serviço que está adquirindo e tem como consequência fazer com que ele tenha maior possibilidade de ser enganado, induzido a erro ou colocado em risco. A vulnerabilidade fática, por sua vez, é caracterizada pela desigualdade de condições econômicas ou intelectuais entre fornecedor e consumidor, característica das relações consumeristas. Por último, a vulnerabilidade científica é a falta de conhecimentos específicos por parte do consumidor, na hora de celebrar um contrato, seja na área jurídica, econômica, contábil etc.

\footnotetext{
incentivo à criação pelos fornecedores de meios eficientes de controle de qualidade e segurança de produtos e serviços, assim como de mecanismos alternativos de solução de conflitos de consumo; VI - coibição e repressão eficientes de todos os abusos praticados no mercado de consumo, inclusive a concorrência desleal e utilização indevida de inventos e criações industriais das marcas e nomes comerciais e signos distintivos, que possam causar prejuízos aos consumidores; VII - racionalização e melhoria dos serviços públicos; VIII - estudo constante das modificações do mercado de consumo.

${ }^{107}$ REsp. 586.316/MG.

${ }^{108}$ MARQUES, Claudia Lima; BENJAMIN, Antônio Herman V.; MIRAGEM, Bruno. Comentários ao Código de Defesa do Consumidor, cit. p. 197-198.

${ }^{109}$ MARQUES, Claudia Lima; BENJAMIN, Antônio Herman V.; MIRAGEM, Bruno. Comentários ao Código de Defesa do Consumidor, cit. p. 198.
} 


\subsubsection{Conceito de consumidor}

Conforme definição prevista no artigo $2^{\circ}$ da Lei $n^{\circ} .8 .078 / 90$, "consumidor é toda pessoa física ou jurídica que adquire ou utiliza produto ou serviço como destinatário final”, sendo a ele equiparados "a coletividade de pessoas, ainda que indetermináveis, que haja intervindo nas relações de consumo" (de acordo com o parágrafo único do referido artigo); "todas as vítimas do evento" danoso, em caso de responsabilidade pelo fato do produto (consoante o artigo 17), bem como, "todas as pessoas determináveis ou não, expostas às práticas" comerciais (conforme o artigo 29).

Diante da imensa capacidade de criação de grandes riscos a um indeterminado número de pessoas agregada a certos produtos presentes na sociedade de consumo, produção e distribuição em massa, faz-se necessária a adoção de um entendimento amplo de consumidor, que deve ser aqui conceituado como toda e qualquer pessoa que tenha contato, direto ou indireto, com o serviço prestado ou com o produto fornecido potencialmente perigoso ou lesivo à sua vida, saúde ou integridade física.

É importante frisar que os crimes causados em decorrência da fabricação ou comercialização de produtos defeituosos que venham a afetar os bens jurídicos saúde, vida ou integridade física do consumidor, seja por intermédio de sua colocação em perigo ou de sua efetiva lesão, terão o consumidor como sujeito passivo.

\subsubsection{Direitos do consumidor relativos à colocação de produtos no mercado}

Conforme explicação anterior, o consumidor é entendido como vulnerável pelo artigo $4^{\circ}$, I, do CDC. Tal característica já havia sido considerada pela Constituição de 1988 quando determinou no inciso XXXII de seu artigo $5^{\circ}$, que trata dos Direitos e Garantias Fundamentais $^{110}$, que o Estado deveria promover a defesa do consumidor ${ }^{111}$. Neste sentido,

a Constituição estabelece o prazo de cento e vinte dias após sua promulgação para a que

\footnotetext{
${ }^{110}$ A edição de um Código de Defesa do Consumidor é, portanto, o cumprimento, por parte do Estado, de um Direito Fundamental, qual seja, o de proteção do consumidor, um novo sujeito de direitos, identificado, constitucionalmente, como vulnerável, necessitado de especial proteção.

${ }^{111} \mathrm{CF} / 88$, artigo $5^{\circ}$, XXXII: o Estado promoverá, na forma da lei, a defesa do consumidor.
} 
seja elaborado o Código de Defesa do Consumidor ${ }^{112}$. O cumprimento deste dispositivo constitucional se deu por meio da edição da Lei no 8078/90, que elenca, em seu artigo $6^{\circ}$, os chamados direitos básicos do consumidor.

Diz respeito ao presente tema a proteção relacionada ao fornecimento de produtos. Neste sentido, interessam: a proteção à vida, saúde e segurança; liberdade de escolha e informação $^{113}$.

\section{a) Direito de proteção contra riscos à vida, saúde e segurança}

O inciso I do artigo $6^{\circ}$ do CDC consagra como direito básico do consumidor a proteção contra riscos à vida, saúde e segurança provocados por práticas no fornecimento de produtos perigosos ou nocivos. O consumidor tem o direito a não ter sua vida, saúde e segurança expostas por produtos, a riscos que sejam maiores do que aqueles normalmente previstos e, por isso, por ele esperados.

A responsabilidade dos fornecedores pelos riscos e danos advindos da colocação de produtos potencialmente lesivos no mercado de consumo se fundamenta na chamada teoria da qualidade, segundo a qual, ao fornecedor cabe cumprir um "dever de qualidade" em relação aos produtos e serviços por ele disponibilizados no mercado consumidor. Deste modo, o fornecedor deve comercializar apenas produtos seguros, caso contrário, será responsabilizado $^{114}$.

Na precisa lição de HERMAN BENJAMIN, "a teoria da qualidade forma-se com os olhos voltados para o instituto da responsabilidade do fornecedor: civil, administrativa e penal. De nada adiantaria criar-se um dever de qualidade se o seu desrespeito não trouxesse consequências para o violador. Tanto no direito administrativo como no direito penal, a teoria da qualidade apresenta um colorido predominantemente repressivo. Já pelo

\footnotetext{
${ }^{112}$ ADCT, art. 48. O Congresso Nacional, dentro de cento e vinte dias da promulgação da Constituição, elaborará código de defesa do consumidor.

${ }^{113}$ BENJAMIN, Antônio Herman V.; MARQUES, Cláudia Lima; BESSA, Leonardo Roscoe. Manual de direito do consumidor, cit., p. 57.

${ }^{114}$ MARQUES, Claudia Lima; BENJAMIN, Antônio Herman V.; MIRAGEM, Bruno. Comentários ao Código de Defesa do Consumidor, cit.
} 
prisma da responsabilidade civil, o tom principal é dado pela reparação, elemento essencial para o consumidor lesado". 115

Da teoria da qualidade decorre a necessidade de serem observadas a qualidadeadequação e a qualidade-segurança ${ }^{116}$ que, quando descumpridas, geram os chamados vícios dos produtos. A não observação da primeira faz surgirem os vícios de qualidade por inadequação, que nada mais são do que são do que vícios que tornam o produto impróprio ou inadequado ao consumo a que se destinam ou que lhes diminua o valor ${ }^{117}$; e da não observação da última nascem os vícios de qualidade por insegurança, ou seja, aqueles capazes de colocar em risco a saúde, vida ou integridade física dos consumidores ${ }^{118}$.

Como consequência do direito do consumidor à proteção contra riscos à vida, saúde e segurança, os artigos $8^{\circ}$ a $10^{\circ}$ da Lei 8.078/90 proíbem o fornecedor de colocar no mercado de consumo produtos que excedam a legítima expectativa de segurança do consumidor, além de obrigá-los a informar ostensiva e adequadamente a respeito de periculosidade que seja a ele inerente, bem como aquela decorrente de defeito do qual tenha tido conhecimento somente após sua comercialização.

\section{b) Direito à divulgação sobre o consumo adequado dos produtos}

Um dos direitos previstos no artigo $6^{\circ}$, inciso II, é o direito que o consumidor possui à divulgação sobre o consumo adequado dos produtos. Essa garantia é importante na medida em que as práticas de marketing estão cada vez mais agressivas e são decisivas na escolha do que será adquirido pelo consumidor ${ }^{119}$.

A aquisição de produtos, portanto, deve poder ser feita tomando-se como base, quando for o caso de haver publicidade a seu respeito, informação correta e fundamentada. De acordo com CLÁUDIA LIMA MARQUES, este direito trata-se de um "direito mais

\footnotetext{
${ }^{115}$ BENJAMIN, Antônio Herman V.; MARQUES, Cláudia Lima; BESSA, Leonardo Roscoe. Manual de direito do consumidor, cit., p. 108.

${ }^{116}$ MARQUES, Claudia Lima; BENJAMIN, Antônio Herman V.; MIRAGEM, Bruno. Comentários ao Código de Defesa do Consumidor, cit., p. 245.

${ }^{117} \mathrm{CDC}$, artigos 18 a 23.

${ }^{118} \mathrm{CDC}$, artigos 12 a 17.

${ }^{119}$ MARQUES, Claudia Lima; BENJAMIN, Antônio Herman V.; MIRAGEM, Bruno. Comentários ao Código de Defesa do Consumidor, cit. p. 245.
} 
forte de informação", que está protegido, no que concerne à responsabilidade pelos vícios de qualidade por insegurança referente a produtos, nos artigos 30 e 31 do CDC $^{120}$.

Apenas como exemplo, deve-se lembrar o caso Talidomida, detalhado no último capítulo, no qual a venda do medicamento foi estimulada por forte propaganda que alegava ser o produto atóxico, pois não haveria qualquer efeito colateral ao seu uso. No entanto, mulheres gestantes que fizeram uso do medicamento, acabaram dando à luz crianças portadoras de graves deformidades físicas conduzindo numerosas delas a morte, dentre outros danos causados pelo referido produto.

\section{c) Direito à informação}

O direito à informação está previsto pelo artigo $5^{\circ}$, XIV da Constituição Federal e é um corolário dos Princípios da Confiança, da Transparência, e da Boa-fé Objetiva ${ }^{121}$.

Trata-se de um dos mais importantes direitos do consumidor, especialmente, se relacionado ao fornecimento de produtos, conforme previsto no inciso III do artigo $6^{\circ}$, que diz respeito ao direito à informação adequada e clara sobre os diferentes produtos inclusive aquelas sobre os riscos que apresentem.

O direito à informação previsto pelo CDC é amplo ${ }^{122}$ e abrange, ao que interessa ao presente tema, além da informação sobre os riscos inerentes ao produto, a especificação correta de quantidade, características, composição e qualidade. O Código de Defesa do Consumidor dá imensa importância ao direito à informação relacionada aos produtos colocados no mercado de consumo e, por isso, o protege em diversos dispositivos, dentre os quais: os artigos $8^{\circ}$ e $9^{\circ}$ (que dizem respeito ao dever que o fornecedor tem de dar informações necessárias e adequadas sobre os riscos que produtos naturalmente perigosos ofereçam); $10 \S 1^{\circ}$ (que obriga o fornecedor que souber da periculosidade do produto após sua colocação no mercado a informar o fato aos consumidores e às autoridades competentes); 12 (que trata da responsabilidade civil por defeito de informação, ou seja,

\footnotetext{
${ }^{120}$ BENJAMIN, Antônio Herman V.; MARQUES, Cláudia Lima; BESSA, Leonardo Roscoe. Manual de direito do consumidor, cit., p. 58.

${ }^{121}$ REsp. 586.316/MG.

${ }^{122}$ Além das aqui apresentadas, o Direito à Informação abarca uma série de garantias relativas à boa-fé e equilíbrio contratual, previstas nos diversos incisos do artigo $6^{\circ}$ do CDC.
} 
por informações insuficientes ou inadequadas sobre a utilização e riscos de produtos); 33 (que determina que seja identificada a origem do produto vendido à distância).

O consumidor, ao adquirir um produto, apresenta expectativas sobre sua utilidade, bom funcionamento, qualidade e, também, sobre sua segurança. Ele confia que o fornecedor tenha agido com boa-fé, não apenas na elaboração do produto, mas também, na disponibilização de informações a seu respeito, contidas em suas embalagens, manuais, anúncios e advertências. Dito de outro modo, o consumidor espera que as informações apresentadas acerca do produto sejam compatíveis com a realidade.

De acordo com CLÁUDIA LIMA MARQUES, o Código de Defesa do Consumidor protege a confiança que o consumidor deposita no fornecedor através de normas imperativas ${ }^{123}$, "mais especificamente na prestação contratual, na sua adequação ao fim que razoavelmente dela se espera, e irão proteger também a confiança que o consumidor deposita na segurança do produto ou do serviço colocado no mercado" ${ }^{24}$.

Por outro lado, depreende-se do Princípio da Confiança que o consumidor crê fielmente que o produtor e fornecedor de produtos agirá conforme o Direito e, deste modo, não deixará de cumprir seus deveres objetivos de cuidado nem, muito menos, colocará no mercado de consumo produto que sabe ser perigoso além do que se possa legitimamente esperar.

O direito à informação, portanto, no que diz respeito à proteção à saúde, vida e integridade física do consumidor, na precisa lição de Herman Benjamin "é a manifestação autônoma da obrigação da segurança. Informação adequada nos termos do art. $6^{\circ}$, III, do CDC é, aquela que se apresenta simultaneamente completa, gratuita e útil”125.

$\mathrm{O}$ direito que o consumidor tem à informação é tão abrangente que obriga, inclusive, a União, os Estados, o Distrito Federal e os Municípios que deverão cumpri-lo toda vez que tomarem ciência da periculosidade de produtos à saúde ou segurança do consumidor, por força do artigo $10 \S 3^{\circ}$.

\footnotetext{
${ }^{123} \mathrm{O}$ artigo 30 do CDC, por exemplo: "Toda informação ou publicidade, suficientemente precisa, veiculada por qualquer forma ou meio de comunicação com relação a produtos e serviços oferecidos ou apresentados, obriga o fornecedor que a fizer veicular ou dela se utilizar e integra o contrato que vier a ser celebrado".

${ }^{124}$ MARQUES, Cláudia Lima. Contratos no Código de Defesa do Consumidor: o novo regime das relações contratuais. 5. ed. São Paulo: Ed. Revista dos Tribunais, 2005. p.1142.

${ }^{125}$ REsp. 586.316/MG.
} 


\subsubsection{O fornecedor e seus deveres}

\subsubsection{Conceito de fornecedor}

A Diretiva ${ }^{126} 875 / 374 /$ CCE, que é o diploma normativo que dispõe acerca da responsabilidade civil decorrente de produtos defeituosos na União Europeia, conceitua como produtor, ou mais precisamente, como o responsável por dano causado por defeito de produto $^{127}$ : o fabricante de um produto acabado, de uma matéria prima ou de uma parte componente, bem como, aquele que identificar o produto com seu nome, marca ou qualquer sinal distintivo. $\mathrm{O}$ importador que tenha como finalidade atividade comercial é equiparado ao produtor e, também, o comerciante que não identificar o produtor $^{128}$.

Importa ressaltar que como a referida Diretiva trata da responsabilidade civil pelo produto defeituoso, determina a quem cabe indenizar civilmente o consumidor por dano por ele sofrido, causado por produto colocado no mercado de consumo. Trata, portanto, de responsabilidade objetiva, não necessitando que se prove a culpa do produtor, mas apenas o dano, o defeito do produto e o nexo causal entre ambos ${ }^{129}$. Não se podendo, no Direito Penal, tratar de responsabilidade com os tais parâmetros, ou seja, objetivamente, com a ausência de dolo ou culpa.

Aquilo que a Diretiva chama de "produtor", ou a ele equipara, o CDC denomina "fornecedor".

O conceito de fornecedor trazido pelo artigo $3^{\circ}$ do Código de Defesa do Consumidor é bastante amplo e abarca qualquer pessoa - "física ou jurídica, pública ou

\footnotetext{
${ }^{126}$ As chamadas "diretivas", conforme o artigo 189 do Tratado de Roma (que, em 25 de março de 1957, constituiu a, então, Comunidade Econômica Europeia, hoje União Europeia), "vincula o Estado-membro destinatário quanto ao resultado a alcançar, deixando, no entanto, às instâncias nacionais a competência quanto à forma e aos meios". Norma disponível em: http://eur-lex.europa.eu/LexUriServ/LexUriServ.do? uri=CELEX:31985L0374: pt:HTML. Acesso em 19 de setembro de 2008.

${ }^{127}$ Art. $1^{\text {o: }}$ O produtor é responsável pelo dano causado por um defeito do seu produto

${ }^{128}$ Art. $3^{\circ}$ : 1 . O termo "produtor" designa o fabricante de um produto acabado, o produtor de uma matériaprima ou o fabricante de uma parte componente, e qualquer pessoa que se apresente como produtor pela aposição sobre o produto do seu nome, marca ou qualquer outro sinal distintivo. 2. Sem prejuízo da responsabilidade do produtor, qualquer pessoa que importe um produto na Comunidade tendo em vista uma venda, locação, locação financeira ou qualquer outra forma de distribuição no âmbito da sua atividade comercial, será considerada como produtor do mesmo, na acepção da presente diretiva, e responsável nos mesmos termos que o produtor. 3. Quando não puder ser identificado o produtor do produto, cada fornecedor será considerado como produtor, salvo se indicar ao lesado, num prazo razoável, a identidade do produtor ou daquele que lhe forneceu o produto. O mesmo se aplica no caso de um produto importado, se este produto não indicar o nome do importador referido no 2, mesmo se for indicado o nome do produtor.

${ }^{129}$ Art. $4^{\circ}$ : Cabe ao lesado a prova do dano, do defeito e do nexo causal entre o defeito e o dano.
} 
privada, nacional ou estrangeira, bem como os entes despersonalizados" - que desenvolva atividade de produção, montagem, criação, construção, transformação, importação, exportação, distribuição ou comercialização de produtos ou prestação de serviços.

Para que seja entendido como fornecedor de produto é necessário que a atividade de fornecimento prestada seja profissional, apresentando o caráter de habitualidade ${ }^{130}$, sendo excluídos do conceito, portanto, aqueles que fornecem eventualmente um produto ${ }^{131}$. Neste sentido, alguém que venda um automóvel particular para outra pessoa não é, evidentemente, fornecedor de automóveis.

JOSÉ GERALDO DE BRITO FILOMENO, ao analisar a definição de fornecedor insculpida no artigo $3^{\circ}$ do CDC, assevera que fornecedor é "o protagonista das sobreditas relações de consumo responsável pela colocação de produtos e serviços à disposição do consumidor" 132 .

Com efeito, tal definição nos é bastante conveniente, já que, ao tratar de responsabilidade penal pelo fornecimento de produtos, nos parece adequado entender fornecedor como a pessoa responsável pela colocação de produtos no mercado à disposição do consumidor. Devemos, entretanto, para a imputação de responsabilidade penal, sempre subjetiva, nos restringir às pessoas físicas, diretores ou funcionários das empresas responsáveis por essa produção e comercialização de bens de consumo com potencial lesivo no mercado.

Como fornecedor, neste sentido, podemos considerar toda pessoa natural que cria (desenha, planeja, projeta) monta, constrói (produz, fabrica), transforma, importa, exporta, distribui ou comercializa produtos, seja diretamente, seja em razão de sua colocação profissional em cadeia empresarial como empregado ou diretor de empresa.

\footnotetext{
${ }^{130}$ GRINOVER, Ada Pellegrini; BENJAMIN, Antônio Herman de Vasconcellos e; FINK, Daniel Roberto; FILOMENO, José Geraldo Brito; WATANABE, Kazuo; NERY JÚNIOR, Nelson; DENARI, Zelmo. Código brasileiro de defesa do consumidor comentado pelos autores do anteprojeto. 8. ed. Rio de Janeiro: Forense Universitária, 2004. p. 43.

${ }^{131}$ BENJAMIN, Antônio Herman V.; MARQUES, Cláudia Lima; BESSA, Leonardo Roscoe. Manual de direito do consumidor, cit., p. 82.

${ }^{132}$ GRINOVER, Ada Pellegrini; BENJAMIN, Antônio Herman de Vasconcellos e; FINK, Daniel Roberto; FILOMENO, José Geraldo Brito; WATANABE, Kazuo; NERY JÚNIOR, Nelson; DENARI, Zelmo. op. cit., p. 43 .
} 


\subsubsection{Deveres do fornecedor de produtos}

Ao colocar produtos no mercado de consumo, o fornecedor deve observar uma série de deveres inerentes a essa atividade em decorrência de normas cogentes, sejam elas previstas em lei ordinária, resolução, portaria, ou qualquer outra com capacidade de impor deveres legais.

O Código de Defesa do Consumidor, nesta seara, prevê os seguintes deveres gerais ao fornecedor: o dever de fornecimento de produtos seguros; o dever de informação; o dever de comunicação da inesperada periculosidade ou nocividade do produto; e o dever de retirada.

\section{a) Dever de fornecimento de produtos seguros}

A primeira parte do caput do artigo $8^{\circ}$ do CDC determina aos fornecedores o dever de fornecer produtos seguros ao consumidor, proibindo, assim, que os produtos colocados no mercado afrontem a legítima expectativa de segurança que os consumidores tenham em relação a eles ${ }^{133}$. O artigo 10 do referido diploma legal, por sua vez, proíbe a colocação no mercado de consumo de produto com alto grau de nocividade ou periculosidade cujo fornecedor tenha ou deveria ter conhecimento ${ }^{134}$. Isso, também, quer dizer que os produtos não podem gerar aos consumidores risco superior àquele por eles legitimamente esperado em razão de sua natureza.

A obrigação de fornecer produtos que sejam seguros conforme a legítima expectativa do consumidor é decorrente de seu direito de proteção à vida, saúde e segurança contra os riscos provocados por práticas no fornecimento de produtos e serviços considerados perigosos ou nocivos, insculpido no inciso I do artigo $6^{\circ}$ do Código de Defesa do Consumidor. A teoria da qualidade exige, neste ponto, a chamada qualidade-segurança, acima esclarecida.

\footnotetext{
${ }^{133} \mathrm{CDC}$, art. $8^{\circ}$, caput, $1^{\text {a }}$ parte: Os produtos e serviços colocados no mercado de consumo não acarretarão riscos à saúde ou segurança dos consumidores, exceto os considerados normais e previsíveis em decorrência de sua natureza e fruição.

${ }^{134} \mathrm{CDC}$, art. 10. O fornecedor não poderá colocar no mercado de consumo produto ou serviço que sabe ou deveria saber apresentar alto grau de nocividade ou periculosidade à saúde ou segurança.
} 
Podem ser fornecidos produtos com nocividade ou periculosidade natural, ou até desejável (como é o exemplo dos inseticidas e das facas, respectivamente) ao mercado de consumo, desde que, por força do artigo $9^{\circ}$, haja informações suficientes a seu respeito para que sejam evitados danos por eles causados. A mesma regra vale para produtos industriais, que devem ser acompanhados por informação impressa (CDC, art. $8^{\circ}$, parágrafo único). É, no entanto, vedada a comercialização de produtos de alta nocividade ou periculosidade à saúde ou à segurança (art. 10, caput), não explicando o Código aquilo que considera como "alta nocividade ou periculosidade", sendo, portanto, reservada a tarefa de hermenêutica da expressão ao magistrado na análise do caso concreto.

Regulando, ainda, as práticas comerciais, o artigo 39, VIII do CDC entende como abusivo colocar "no mercado de consumo, qualquer produto (...) em desacordo com as normas expedidas pelos órgãos oficiais competentes ou, se normas específicas não existirem, pela Associação Brasileira de Normas Técnicas ou outra entidade credenciada pelo Conselho Nacional de Metrologia, Normalização e Qualidade Industrial (Conmetro)”.

A afronta a este comando, por meio da colocação no mercado de consumo de produtos em desacordo com a legítima expectativa de segurança que os consumidores tenham em relação a eles, gera uma série de consequências nas diversas esferas da ordem jurídica. Os artigos 12 e 18 do CDC, neste sentido, preveem, respectivamente, a responsabilidade civil objetiva pelos "danos causados aos consumidores por defeitos decorrentes de projeto, fabricação, construção, montagem, fórmulas, manipulação, apresentação ou acondicionamento de seus produtos, bem como por informações insuficientes ou inadequadas sobre sua utilização e riscos" e "pelos vícios de qualidade (...) que os tornem impróprios ou inadequados ao consumo a que se destinam". O parágrafo $6^{\circ}$ do artigo 18 trata de explicitar o que é entendido por produto impróprio ao uso e consumo. A regulação administrativa, por sua vez, é estabelecida pelos artigos 55 e seguintes do CDC. O art. 55 prevê a competência concorrente da União, dos Estados e do Distrito Federal na edição de normas relativas à produção, industrialização, distribuição e consumo de produtos. $\mathrm{O} \S 1^{\circ}$ do referido artigo, estabelece que a União, os Estados, o Distrito Federal e, também, os Municípios fiscalizarão e controlarão as supracitadas atividades, "no interesse da preservação da vida, da saúde, da segurança, da informação e do bem-estar do consumidor, baixando as normas que se fizerem necessárias". O artigo 56 estabelece que em caso de infração às normas de defesa do consumidor, cabem, as seguintes sanções administrativas: I - multa; II - apreensão do produto; III - inutilização do produto; IV - 
cassação do registro do produto junto ao órgão competente; V - proibição de fabricação do produto; VI - suspensão de fornecimento de produtos ou serviço; VII - suspensão temporária de atividade; VIII - revogação de concessão ou permissão de uso; IX - cassação de licença do estabelecimento ou de atividade; X - interdição, total ou parcial, de estabelecimento, de obra ou de atividade; XI - intervenção administrativa; XII - imposição de contrapropaganda.

Embora haja tamanha preocupação do CDC, conforme já exposto, naquilo que diz respeito à produção e comercialização de produtos perigosos à saúde, vida e integridade física do consumidor, regulando as consequências a esta prática civil e administrativamente, operou-se o veto presidencial, justamente, no dispositivo que protegeria penalmente o consumidor da referida prática ${ }^{135}$.

\section{b) Dever de informação}

O dever de informação obriga o fornecedor de produtos na fase de sua elaboração (quando estabelece as informações constantes nos produtos propriamente ditos, em suas embalagens e seus manuais, bulas ou qualquer outra espécie de material informativo que os acompanhe), comercialização (especialmente, em relação à oferta e publicidade do produto) e, também, no momento posterior à sua venda ao consumidor final, quando há a obrigação de verificar se o produto possui periculosidade ou nocividade que não tenha sido anteriormente estabelecida ${ }^{136}$.

Tal obrigação determina que o fornecedor deva informar adequada e suficientemente ao consumidor acerca da existência de riscos à sua segurança além do esperado em decorrência da natureza do produto e sua normal utilização (art. $8^{\circ}$, in fine, CDC), em especial e ostensivamente, em caso de produtos de natureza potencialmente nociva ou perigosa à saúde e segurança (art. $\left.9^{\circ}, \mathrm{CDC}\right)$.

Os parágrafos $1^{\circ}$ e $2^{\circ}$ do artigo 10 , por sua vez, determinam ao fornecedor que tenha tomado conhecimento da nocividade ou periculosidade do produto após sua colocação no mercado, que informe este fato aos consumidores e às autoridades

\footnotetext{
${ }^{135}$ Trata-se do veto ao art. 62 do CDC, explicado em detalhes no item

${ }^{136}$ MARQUES, Claudia Lima; BENJAMIN, Antônio Herman V.; MIRAGEM, Bruno. Comentários ao Código de Defesa do Consumidor, cit., p. 58.
} 
competentes por meio de anúncios publicitários veiculados na imprensa, rádio e televisão, sendo estes informes feitos às suas custas. Essa medida procura minimizar os danos causados aos consumidores em decorrência dessa consciência tardia, por parte do fornecedor, a respeito do risco de comercialização do referido produto.

Há, ainda, a obrigação de informar relativa à oferta e à apresentação de produtos, prevista no artigo 31. Neste caso, o fornecedor deve se certificar que o produto traga “informações corretas, claras, precisas, ostensivas e em língua portuguesa sobre suas características, qualidades, quantidade, composição, preço, garantia, prazos de validade e origem, entre outros dados, bem como sobre os riscos que apresentam à saúde e segurança dos consumidores" ${ }^{137}$. Por fim, além dessas previsões acerca do dever de informar, há a obrigação prevista no artigo 33 que determina que no produto vendido a distância deva constar "o nome do fabricante e endereço na embalagem, publicidade e em todos os impressos utilizados na transação comercial”.

O dever de o fornecedor informar adequada e suficientemente a respeito do produto decorre do direito básico do consumidor à informação, insculpido no art. $6^{\circ}$ III do CDC, bem como, à segurança, previsto no art. 6, ${ }^{\circ} \mathrm{I}$ e seu descumprimento gera reflexos nas esferas civil, administrativa e penal.

O artigo 12 do CDC prevê a responsabilidade civil objetiva pelos "danos causados aos consumidores por defeitos decorrentes de (...) informações insuficientes ou inadequadas sobre sua utilização e riscos" e o artigo 18 "pelos vícios (...) decorrentes da disparidade, com as indicações constantes do recipiente, da embalagem, rotulagem ou mensagem publicitária, respeitadas as variações decorrentes de sua natureza".

Os artigos 55 e seguintes do CDC estabelecem a regulação administrativa e as consequências a seu descumprimento, já explicitados anteriormente.

As consequências penais, por sua vez são amplamente previstas. $\mathrm{O}$ art. 63 , neste sentido, criminaliza a conduta de "omitir dizeres ou sinais ostensivos sobre a nocividade ou periculosidade de produtos, nas embalagens, nos invólucros, recipientes ou publicidade", cominando a ela a pena de detenção de seis meses a dois anos e multa. Esta conduta admite a modalidade culposa $\left(\S 2^{\circ}\right)$ que pune com detenção de um a seis meses ou multa. $\mathrm{O}$ art. 66, por sua vez, impõe a pena de detenção de três meses a um ano e multa para quem fizer

\footnotetext{
${ }^{137}$ A Lei $n^{\circ}$. 11.989/09 incluiu um parágrafo único ao referido artigo, determinando que tais informações, quando constarem de produtos refrigerados, deverão ser gravadas de forma indelével, ou seja, que não possam desaparecer, tornando, deste modo, seu consumo mais seguro.
} 
"afirmação falsa ou enganosa, ou omitir informação relevante sobre a natureza, característica, qualidade, quantidade, segurança, desempenho, durabilidade, preço ou garantia de produtos", pena esta que estende a "quem patrocinar a oferta" $\left(\S 1^{\circ}\right)$. Também sendo admitida a título de culpa $\left(\S 2^{\circ}\right)$, com pena de detenção de um a seis meses ou multa.

\section{c) Dever de comunicação da inesperada periculosidade ou nocividade do produto}

O fornecedor não pode colocar no mercado de consumo produto que sabe ou que deveria saber apresentar alto grau de nocividade ou periculosidade à saúde ou segurança (art. 10, $\mathrm{CDC}$ ) a não ser quando isso for compatível com a sua natureza. Pode acontecer, eventualmente, que apenas após a colocação do produto no mercado de consumo é que se perceba o seu caráter nocivo ou lesivo. Cabe ao fornecedor, neste caso, comunicar autoridade competente e consumidores acerca da inesperada periculosidade apresentada pelo produto, percebida após sua introdução no mercado de consumo (art. 10 $, \S 1^{\circ}, \mathrm{CDC}$ ).

Este dever decorre do direito básico do consumidor à proteção da vida, saúde e segurança contra os riscos provocados por práticas no fornecimento de produtos perigosos ou nocivos ( $\left.6^{\circ}, \mathrm{I}, \mathrm{CDC}\right)$, bem como, à informação adequada e clara sobre os riscos que apresentem ( $\left.6^{\circ}, \mathrm{III}, \mathrm{CDC}\right)$, dever este que obriga, também, União, Estados, Distrito Federal e Municípios, por força do Art. $10^{\circ} \S 3^{\circ}$.

As consequências civis e administrativas são, basicamente, as mesmas previstas no caso das violações dos deveres ao fornecimento de produtos seguros e à informação: responsabilidade civil objetiva e as sanções administrativas elencadas nos artigos 55 e seguintes, anteriormente detalhadas.

$\mathrm{O}$ artigo 64 do CDC comina a pena de detenção de seis meses a dois anos e multa para o fornecedor que "deixar de comunicar à autoridade competente e aos consumidores a nocividade ou periculosidade de produtos cujo conhecimento seja posterior à sua colocação no mercado". 


\section{d) Dever de retirada: o recalll}

O dever de retirada só ocorrerá em caso de ser percebida a periculosidade de produto já colocado no mercado. O fornecedor, neste caso, deve retirar de circulação o produto que tenha percebido ser defeituoso somente após sua disponibilização ao consumidor.

O estabelecimento deste dever se dá como garantia aos direitos do consumidor a proteção da vida, saúde e segurança contra os riscos provocados por práticas no fornecimento de produtos perigosos ou nocivos (6 $\left.6^{\circ}, \mathrm{I}, \mathrm{CDC}\right)$, bem como, à informação adequada e clara sobre os diferentes produtos e serviços, com especificação correta sobre os riscos que apresentem $\left(6^{\circ}, \mathrm{III}, \mathrm{CDC}\right)$.

Este dever decorre da obrigação de que os produtos colocados no mercado de consumo não acarretarão riscos à saúde ou segurança dos consumidores, exceto os considerados normais e previsíveis em decorrência de sua natureza e fruição, obrigando-se os fornecedores, em qualquer hipótese, a dar as informações necessárias e adequadas a seu respeito (art. $8^{\circ} \mathrm{CDC}$ ). Deriva, também, da obrigação de informar, de maneira ostensiva e adequada, a respeito da sua nocividade ou periculosidade de produtos potencialmente nocivos ou perigosos à saúde ou segurança (art. $9^{\circ}, \mathrm{CDC}$ ), bem como, da vedação ao fornecedor de colocar no mercado de consumo produto que sabe ou deveria saber apresentar alto grau de nocividade ou periculosidade à saúde ou segurança (art. 9, CDC).

O dever de retirada, estendido ao Poder Público, está expresso nos parágrafos do art. $9^{\circ}$ :

$\S 1^{\circ} \mathrm{O}$ fornecedor de produtos e serviços que, posteriormente à sua introdução no mercado de consumo, tiver conhecimento da periculosidade que apresentem, deverá comunicar o fato imediatamente às autoridades competentes e aos consumidores, mediante anúncios publicitários.

$\S 2^{\circ}$ Os anúncios publicitários a que se refere o parágrafo anterior serão veiculados na imprensa, rádio e televisão, às expensas do fornecedor do produto ou serviço.

$\S 3^{\circ}$ Sempre que tiverem conhecimento de periculosidade de produtos ou serviços à saúde ou segurança dos consumidores, a União, os Estados, o Distrito Federal e os Municípios deverão informá-los a respeito. 
Apresenta as mesmas consequências civis e administrativas previstas para a violação aos deveres acima referidos. A sanção penal decorrente do descumprimento do dever de retirada está prevista no parágrafo único do art. 64 do CDC: detenção de seis meses a dois anos e multa para o fornecedor que deixar de retirar do mercado, imediatamente quando determinado pela autoridade competente, os produtos nocivos ou perigosos.

A questão que se apresenta em relação ao dever de retirada é se ele é exigido do fornecedor mesmo se não determinado pela autoridade competente em decorrência da criação do risco não permitido. Ao considerar-se o artigo $13, \S 2^{\circ}$, c, do Código Penal, que determina como penalmente relevante a omissão daquele que, com seu comportamento anterior, tenha criado o risco da ocorrência do resultado, não restam dúvidas a respeito da referida exigência. $\mathrm{O}$ fornecedor é obrigado a retirar do mercado de consumo e, desta forma, do acesso ao público consumidor, produto do qual tenha conhecimento ser defeituoso, ainda que não determinado por autoridade competente pois, foi ele quem o colocou em circulação anteriormente.

Para encerrar, é importante que se referencie que, por força do art. 75, quem concorrer, de qualquer forma, para os crimes previstos no Código de Defesa do Consumidor, incide as penas a eles cominadas na medida de sua culpabilidade. $\mathrm{O}$ dispositivo faz menção taxativa às figuras do diretor, do administrador e do gerente da pessoa jurídica que promover, permitir ou por qualquer modo aprovar o fornecimento, oferta, exposição à venda ou manutenção em depósito de produtos ou nas condições proibidas pelo CDC. Este dispositivo deve ser observado com cuidado, pois pode levar à responsabilização penal objetiva.

\subsection{O produto}

\subsubsection{Conceito de produto}

O conceito de produto adotado pelo Código de Defesa do Consumidor é bastante amplo, englobando "qualquer bem, móvel ou imóvel, material ou imaterial", conforme o artigo $3^{\circ} \S 1$. 
De acordo com JOSÉ GERALDO DE BRITTO FILOMENO, "para fins do Código de Defesa do Consumidor, produto (entenda-se bens) é qualquer objeto de interesse em dada relação de consumo, e destinado a satisfazer uma necessidade do adquirente, como destinatário final" ${ }^{138}$.

Na Europa o conceito de produto foi apresentado, em 25 de julho de 1985, pela já referida Diretiva 85/374/CEE. Esta diretiva, que, conforme anteriormente citado, trata da responsabilidade civil decorrente de produtos defeituosos, foi bastante mais restritiva que a lei brasileira, entendendo, inicialmente, como "produto" os bens móveis industrializados, ainda que utilizados na construção de imóveis ou neles incorporados e a eletricidade, sendo excluídos de seu âmbito os produtos agrícolas e de caça ${ }^{139}$ (a menos que tivessem sofrido uma transformação industrial capaz de neles gerar defeitos) e também, os danos nucleares ${ }^{140}$. Em 1999, devido à imensa preocupação com os riscos e danos causados pela colocação de produtos no mercado de consumo, é apresentado pela Comissão das Comunidades Europeias (CCE), um "Green Paper" ${ }^{141}$ sobre a Responsabilidade Civil decorrente dos produtos defeituosos ${ }^{142}$, que acaba por gerar a revisão da Diretiva 85/374/CEE. Em 10 de maio de 1999, então, com o intuito de manter-se a harmonia entre as legislações dos Estados-membros, é publicada a Diretiva 1999/34/CE, que tem como principal diretriz reparar a omissão das matérias-primas agrícolas e de caça no conceito de "produto" estabelecido pela Diretiva anterior, não prevendo qualquer possibilidade de derrogação pelos Estados-membros. A partir daí, passa-se a conceituar produto de forma mais abrangente, como “'qualquer bem móvel, mesmo se incorporado noutro bem móvel ou imóvel”, assim como a eletricidade. Os produtos agrícolas e de caça, deste modo, não restaram mais excluídos.

\footnotetext{
${ }^{138}$ GRINOVER, Ada Pellegrini; BENJAMIN, Antônio Herman de Vasconcellos e; FINK, Daniel Roberto; FILOMENO, José Geraldo Brito; WATANABE, Kazuo; NERY JÚNIOR, Nelson; DENARI, Zelmo. op. cit., p. 48.

${ }^{139} \mathrm{~A}$ diretiva orientava, no entanto, que, nos países onde essa exclusão fosse considerada injustificada, poderiam ser elaboradas normas, ampliando a responsabilidade a estes produtos (art. 15).

${ }^{140}$ São excluídos os danos decorrentes de acidentes nucleares cobertos por convenções internacionais ratificadas pelos Estados-Membros (art. 14).

${ }^{141}$ Os "Green Papers" ou "Livros Verdes" são documentos publicados pela Comissão das Comunidades Europeias que buscam promover um processo de consulta por meio de debates entre organismos e particulares, em todo o continente, sobre determinado assunto, baseado nas propostas que neles são apresentadas. EUROPA. Glossário - Livros Verdes.. Disponível em: $<$ http://europa.eu/scadplus/glossary/green_paper_pt.htm>.

${ }^{142}$ COMISSÃO DAS COMUNIDADES EUROPÉIAS. Livro Verde. A responsabilidade civil decorrente dos produtos defeituosos (apresentado pela Comissão) Bruxelas, 28.07.1999. COM(1999)396 final. Disponível em: $\quad<$ http://ec.europa.eu/enterprise/policies/single-market-goods/files/goods/docs/liability/1999greenpaper/com1999-396_pt.pdf>.
} 
A preocupação com a inclusão de produtos agrícolas e de caça e consequente ampliação do conceito de produto não acontece por acaso, mas em decorrência da crise da chamada "doença da vaca-louca" que desde $1986^{143}$ se expandia pelo continente europeu. As vítimas de danos causados, também, por esses produtos passaram, deste modo, a fazer jus à indenização sem que houvesse a necessidade de se provar negligência do produtor ou importador, sendo suficiente a prova quanto ao nexo de causalidade entre o dano e o produto defeituoso.

O Código de Defesa do Consumidor, de 1990, já trouxe, desde sua origem, o conceito de produto amplo, sem qualquer restrição a qualquer espécie de bem.

Embora a maior parte das relações de consumo tenha por objeto bens móveis ${ }^{144}$, sendo, por isso, a maioria dos acidentes de consumo deles decorrentes, o presente trabalho abrange todos os bens materiais sejam eles móveis ou imóveis, excluindo-se, por óbvio, os imateriais que, por sua própria natureza, não teriam a capacidade de gerar lesão aos bens jurídicos saúde, vida e integridade física.

\subsubsection{Legítima expectativa como princípio geral da segurança dos bens de consumo}

O conceito de segurança é relativo, em especial, no que diz respeito a produtos. Ainda que, de forma ideal, se pudesse imaginar uma linha de produção que resultasse em cem por cento de produtos seguros, sabe-se que, ao falar-se em linhas de produção em massa, a eliminação total de risco, chegando-se ao chamado "risco zero", é, na realidade,

\footnotetext{
${ }^{143}$ Em 1986 surge o primeiro caso da "doença da vaca-louca" ou Encefalopatia Espongiforme Bovina, assim identificada pelo Laboratório Veterinário Central da Grã-Bretanha. Apenas em 1988, após a constatação e declaração oficial de que a doença da vaca louca poderia ser transmitida para a espécie humana, a venda de leite de vacas doentes é proibida naquele país. Em 1990, o Governo volta atrás e declara que a doença não afeta a saúde humana. Edita, no entanto, normas para controlar os riscos dela decorrentes. Em 1997, é estabelecida a ligação entre a doença da vaca-louca e uma nova variante da síndrome de Creutzfeld-Jakob (que atinge pacientes na faixa dos vinte anos de idade e apresenta sintomas sensoriais e psiquiátricos e é causada pela transmissão de príons adquiridos em decorrência do consumo de carne e vísceras bovinas oriundas de animais afetados pela Encefalopatia Espongiforme Bovina), doença que em 1995, havia feito sua primeira vítima fatal. CRONOLOGIA da crise da doença da vaca louca na GrãBretanha. $\quad B B C \quad$ Brasil, $30 \quad$ jan. $2001 . \quad$ Disponível em: <http://www.bbc.co.uk/portuguese/noticias/2001/010130_bsecronologia.shtml>.

${ }^{144}$ SANSEVERINO, Paulo de Tarso Vieira. Responsabilidade civil no Código do Consumidor e a defesa do fornecedor. 3. ed. São Paulo: Saraiva, 2010. p. 131.
} 
impossível. Por maiores que sejam os cuidados tomados pelos fabricantes durante os processos produtivos, há, e sempre haverá, um "resíduo de insegurança" ${ }^{145}$.

Há situações nas quais, se verifica o cumprimento de todos os protocolos, a completa diligência dos responsáveis pela execução dos deveres de cuidado, respeitando todos os critérios determinados pelos órgãos competentes para a fabricação e comercialização de um produto $^{146}$, mas, ainda assim, há a presença de alguma unidade do produto capaz de ocasionar resultado lesivo a bens jurídicos do consumidor.

O caso de uma empresa de refrigerantes ${ }^{147}$ que tem produção diária de trezentas e vinte mil unidades e, onde, durante uma fiscalização, são encontradas duas garrafas contendo fungos que tornam o refrigerante impróprio para o consumo é, neste sentido, exemplar.

A denúncia pelo Ministério Público de três dirigentes da empresa por crime previsto no artigo $7^{\circ}$, IX, da Lei $\mathrm{n}^{\circ}$. 8.137/90, e a consequente denegação pelo STF do Habeas Corpus que buscava, liminarmente, o trancamento da ação penal, é um caso inequívoco da presença de responsabilidade penal objetiva, uma vez que: a existência de fungos em apenas duas garrafas de refrigerante em um universo de, pelo menos, trezentas e vinte mil, parece ser, não a consequência de descumprimento de dever objetivo de cuidado, mas, ao contrário, a demonstração de que todos os cuidados estão sendo tomados (tanto é assim que nada ao contrário disso foi alegado no processo); mesmo se houvesse a responsabilidade subjetiva de alguma pessoa, não seria, necessariamente, de um de seus dirigentes, devendo-se, em primeiro lugar, aferir quem, agindo com dolo ou ao menos culpa, foi diretamente responsável pelo resultado, se é que houve alguém o foi.

Evidente que, o aumento da segurança - e consequente diminuição de riscos - do processo produtivo acarreta proporcional ao aumento de seus custos e, por isso, nem sempre é interessante ao produtor, ou mesmo, ao consumidor que, muitas vezes, opta pelo preço em detrimento da segurança, opção que não é permitida, contudo, ao fornecedor. Há a necessidade de que o fornecedor de produtos observe atentamente a legislação para que possa afastar a incidência da responsabilidade por eventuais danos causados por seus produtos, especialmente, a responsabilidade penal, sempre decorrente de dolo ou culpa.

\footnotetext{
${ }^{145}$ BENJAMIN, Antônio Herman V.; MARQUES, Cláudia Lima; BESSA, Leonardo Roscoe. Manual de direito do consumidor, cit., p. 117.

${ }^{146}$ Dentre os quais, os chamados "Manuais de Boas Práticas". De acordo com a ANVISA, as "Boas Práticas" compreendem um conjunto de medidas que devem ser adotadas pelas indústrias com o objetivo de garantir a qualidade dos produtos, bem como, sua conformidade com os regulamentos técnicos.

${ }^{147}$ HC 88077/RS.
} 
Pode-se dizer que, para que seja colocado em circulação no mercado em conformidade com o princípio geral da segurança dos bens de consumo ${ }^{148}$, o produto deve atender as expectativas do consumidor em dois aspectos: no que se refere à função objetiva do produto, bem como, no que diz respeito à segurança que legitimamente dele se espera. O descumprimento de qualquer desses aspectos gera o chamado vício do produto ${ }^{149}$.

Não sendo atendida a expectativa do consumidor no que se refere à função, estaremos diante do vício de quantidade ou qualidade por inadequação, conforme o artigo 18 do CDC, isto é: o produto é impróprio ou inadequado ao consumo a que se destina ou tem valor diminuído ou é divergente daquele informado em embalagens ou mensagens publicitárias.

Se o aspecto falho, por outro lado, for aquele que diz respeito à expectativa de segurança que o consumidor legitimamente tem em relação ao produto, o vício apresentado será o de qualidade por insegurança. Apenas esta modalidade de vício pode gerar, após a verificação de uma série de critérios, a responsabilidade penal pelo produto, nos limites abordados no presente trabalho. O produto eivado pelo vício de qualidade por insegurança será equiparado ao produto defeituoso, como passará a ser referido de agora em diante.

Para o Código de Defesa do Consumidor, conforme seu artigo $12 \S 1^{\circ}$, o produto defeituoso é aquele que "não oferece a segurança que dele legitimamente se espera" considerando: (a) sua apresentação; (b) o uso e os riscos que razoavelmente dele se esperam; (c) a época em que foi colocado em circulação.

Podemos, assim, extrair do referido dispositivo que, para que atenda a legítima expectativa de segurança do consumidor, o produto deve estar em consonância com: o que é anunciado em sua apresentação, seja em sua embalagem, rótulo, bula, publicidade ou qualquer outro meio de exposição; o risco razoavelmente esperado pelo consumidor comum, ou seja, aquele que não possui qualquer conhecimento especial sobre o produto; e o conhecimento científico corrente à época em que foi disponibilizado no mercado de consumo.

O conceito de legítima expectativa do consumidor em relação ao produto, trazido para nosso ordenamento jurídico pelo Código de Defesa do Consumidor, foi baseado na

\footnotetext{
${ }^{148} \mathrm{O}$ artigo $8^{\circ}$ da Lei $\mathrm{n}^{\circ}$ 8078/90 determina que os produtos só poderão acarretar à saúde ou segurança dos consumidores os riscos "considerados normais e previsíveis em decorrência de sua natureza e fruição".

${ }^{149}$ BENJAMIN, Antônio Herman V.; MARQUES, Cláudia Lima; BESSA, Leonardo Roscoe. Manual de direito do consumidor, cit., p. 116.
} 
Diretiva 85/374/CEE que, em seu artigo $6^{\circ}$ define que o "produto é defeituoso quando não oferece a segurança que se pode legitimamente esperar".

Para que um produto seja classificado como defeituoso é, ainda, necessário que, além de não atender a legítima expectativa de segurança, tenha a efetiva capacidade de provocar dano a um bem jurídico cujo titular seja o consumidor. Ou seja, é fundamental a presença simultânea de dois elementos para que seja constatado o vício de qualidade por insegurança ou defeito do produto: a desconformidade com a legítima expectativa do consumidor e a capacidade de provocar o chamado "acidente de consumo" ${ }^{150}$. Há casos em que há a desconformidade com a legítima expectativa do consumidor, sem que isso represente a capacidade do produto de provocar acidentes de consumo. Como ocorre com uma peça de roupa com a cor alterada, diferente da anunciada na embalagem e, por isso, diversa da esperada pelo consumidor. Neste caso, estaremos diante de um vício de qualidade por inadequação somente. Não se trata de defeito ${ }^{151}$.

Outra é a situação do produto que possui a capacidade, inerente a ele próprio, de provocar acidentes, isto é, o potencial lesivo do produto é esperado e até mesmo desejado. Esse é o caso das facas de cozinha, por exemplo, que devem ser afiadas para que sejam úteis e atinjam o fim a que se destinam ${ }^{152}$. Nesta situação, também não estaremos diante de um produto defeituoso.

Pode-se concluir que a "legítima expectativa" do consumidor em relação a um produto está intimamente ligada ao princípio geral de segurança dos bens de consumo e se traduz na perspectiva do consumidor de encontrar em determinado produto apenas e tão somente os riscos previsíveis e normais que dele se possa esperar. Dito de outro modo, a normalidade do produto (como critério objetivo), bem como, a previsibilidade por parte do consumidor (como critério subjetivo) são os elementos que compõem a chamada "legítima expectativa" do consumidor em relação à segurança do produto.

A normalidade e a previsibilidade, como critérios da legítima expectativa de segurança relativa ao produto decorrem do artigo $8^{\circ}$ do CDC que proíbe a colocação no mercado de consumo de produtos que exponham a risco a segurança dos consumidores, e prevê como exceção a esta regra os riscos "considerados normais e previsíveis em decorrência de sua natureza e fruição. Isso, portanto, quer dizer que o produto deve apenas

\footnotetext{
${ }^{150}$ BENJAMIN, Antônio Herman V.; MARQUES, Cláudia Lima; BESSA, Leonardo Roscoe. Manual de direito do consumidor, cit., p. 116.

${ }^{151}$ Id., loc. cit.

${ }^{152}$ SANSEVERINO, Paulo de Tarso Vieira. op. cit., p. 140.
} 
apresentar riscos ao consumidor inerentes a sua natureza. E que tais riscos devem ser previsíveis pelo consumidor, se utilizados de forma adequada ao fim a que se destinam, tendo-se em conta os produtos a ele análogos.

\subsubsection{A periculosidade dos produtos e os riscos impostos aos consumidores}

A periculosidade está presente em muitos dos produtos existentes na sociedade moderna. O risco, como já falado, é apresentado nos mais diversos aspectos da vida atual e, os bens de consumo refletem essa tendência. Pode-se, até mesmo, dizer que quase todo o produto traz em si a alguma capacidade de gerar dano.

Para o bom funcionamento do mercado de consumo, no entanto, é essencial que a segurança esteja presente. A ideia de segurança do mercado consumidor decorre do grau de risco que apresenta, ou seja, a maior ou menor probabilidade de que um produto (ou serviço) venha a causar dano a bem jurídico do consumidor ${ }^{153}$.

Ainda que seja fundamental como instrumento de controle social, o Direito não tem força ${ }^{154}$ nem interesse ${ }^{155}$ em proteger o consumidor contra os danos causados por todo e qualquer produto, indistintamente. Mesmo o Direito Civil, que baseia o sistema de reparação de danos causados no âmbito das relações de consumo na responsabilidade objetiva, traz limites à responsabilidade pelo produto ${ }^{156}$. Com muito mais razão, o Direito Penal.

A periculosidade do produto é um conceito decorrente da legítima expectativa do consumidor a respeito do referido bem. Se a periculosidade é previsível, ou até, desejável, não haverá, em condições normais, que se falar em responsabilidade, seja civil ou penal.

Para a melhor compreensão do que, no presente trabalho, é entendido como periculosidade do produto, adotamos a classificação apresentada por ANTÔNIO

\footnotetext{
${ }^{153}$ BENJAMIN, Antônio Herman V.; MARQUES, Cláudia Lima; BESSA, Leonardo Roscoe. Manual de direito do consumidor, cit., p. 116.

${ }^{154}$ SILVA, João Carlos da. Responsabilidade Civil do Produtor. Tese de Doutorado, Coimbra, 1990. In. BENJAMIN, Antônio Herman V.; MARQUES, Cláudia Lima; BESSA, Leonardo Roscoe. Manual de direito do consumidor, cit., p. 116.

${ }^{155} \mathrm{O}$ Direito só tutelará o consumidor quando a insegurança causada pelo produto for além da legítima expectativa no que se refere à normalidade e previsibilidade.

${ }^{156}$ Os elementos da responsabilidade civil pelo produto, de acordo com Paulo de Tarso Vieira Sanseverino, são: o defeito, a imputação, o dano e o nexo causal. SANSEVERINO, Paulo de Tarso Vieira. op. cit., p. 121 .
} 
HERMAN DE VASCONCELLOS E BENJAMIN ${ }^{157}$ que distingue as seguintes espécies: periculosidade inerente, periculosidade adquirida e periculosidade exagerada.

\subsubsection{Periculosidade inerente}

A periculosidade é inerente ou intrínseca ao produto nos casos em que se espera, legitimamente, que o risco esteja presente como qualidade ou modo de seu funcionamento. O referido bem apresenta, em condições normais, um potencial de perigo. Diz-se que se reveste de uma periculosidade natural ${ }^{158}$. Nestes casos, portanto, há a presença da previsibilidade do risco por parte do consumidor e o potencial lesivo do bem que, mais do que previsível, é desejado para que atinja seu fim. Bons exemplos dessa modalidade de produto que devem apresentar um potencial de perigo para realizarem a contento a função que deles legitimamente se espera são as facas, que devem ser afiadas e os inseticidas que devem ser tóxicos.

Nesta situação, a periculosidade é normal e legitimamente esperada, ou seja, há a presença dos elementos essenciais à legítima expectativa de segurança do produto: a normalidade (elemento objetivo, referente ao produto) e a previsibilidade (elemento subjetivo, relativo ao consumidor) do risco latente.

$\mathrm{O}$ artigo $9^{\circ}$ do CDC determina que o fornecedor dos produtos de periculosidade inerente deve "informar, de maneira ostensiva e adequada, a respeito de sua nocividade ou periculosidade" e veda no artigo $10^{\circ}$ a colocação no mercado de produtos com alto grau de nocividade ou periculosidade à saúde ou segurança ${ }^{159}$. Determina, além disso, no $\S 1^{\circ}$ do mesmo artigo, que o fornecedor que só tome conhecimento da periculosidade de seu produto após sua colocação no mercado de consumo deve informar às autoridades competentes e aos consumidores ${ }^{160}$ por meio de anúncios publicitários.

\footnotetext{
${ }^{157}$ BENJAMIN, Antônio Herman V.; MARQUES, Cláudia Lima; BESSA, Leonardo Roscoe. Manual de direito do consumidor, cit., p. 117.

${ }^{158}$ SANSEVERINO, Paulo de Tarso Vieira. op. cit., p. 140.

${ }^{159} \mathrm{O}$ conceito de "alto grau de nocividade ou periculosidade à saúde ou segurança" é bastante impreciso e, de acordo com Zelmo Denari, deve ser aferido pelo aplicador da norma na análise do caso concreto. GRINOVER, Ada Pellegrini; BENJAMIN, Antônio Herman de Vasconcellos e; FINK, Daniel Roberto; FILOMENO, José Geraldo Brito; WATANABE, Kazuo; NERY JÚNIOR, Nelson; DENARI, Zelmo. op. cit., p. 171.

${ }^{160} \mathrm{O} \S 3^{\circ}$ do artigo 10 estende à União, aos Estados, ao Distrito Federal e aos Municípios o dever de informar ao consumidor a respeito da periculosidade de produto do qual tenha conhecimento.
} 
O dever de informar do fornecedor decorre do Direito Básico do Consumidor à informação, previsto no artigo $6^{\circ}$, III do CDC, anteriormente detalhado.

O produto de periculosidade inerente não é um produto defeituoso. Isso, porque o perigo por ele oferecido não decorre de vício de qualidade por insegurança, ao qual chamamos de defeito. Ao contrário, é normal, previsível e desejável.

Raros são os casos, portanto, em que a periculosidade inerente ocasiona a responsabilidade, mesmo civil, do fornecedor pelo produto, pois ela tem como pressuposto o defeito. Poderemos, no entanto, falar em presença de "defeito" do produto de periculosidade inerente se a informação necessária a ele, por força do artigo $9^{\circ}$, for falha. Daí, estaremos diante de um caso de produto de periculosidade adquirida por defeito de comercialização, na modalidade, defeito de informação.

\subsubsection{Periculosidade exagerada}

Trata-se de espécie do gênero periculosidade inerente. Neste caso, porém, o produto possui um "alto grau de nocividade" 161 que a informação dada ao consumidor pelo fornecedor sobre seu potencial de perigo, em nada diminui o risco de sua colocação no mercado de consumo.

Este tipo de produto, portanto, não deveria ser colocado à disposição dos consumidores, pois os benefícios por ele trazidos não justificam os riscos a ele inerentes ${ }^{162}$.

Seria este o caso de um medicamento altamente eficaz no tratamento de determinada doença, mas que tem agregados a seu uso efeitos colaterais de tal gravidade que não justifique sua disponibilização ao consumo. A Talidomida ${ }^{163}$, por exemplo, é um medicamento extremamente eficaz no tratamento da hanseníase. No entanto, seu uso por mulheres grávidas causa deformidades gravíssimas aos fetos. Nada justificaria o consumo da Talidomida por uma mulher grávida, independentemente do quão desenvolvida estivesse a hanseníase que viesse a apresentar.

\footnotetext{
${ }^{161}$ De acordo com HERMAN BENJAMIN, o alto grau de nocividade de um produto, não havendo previsão em lei, deve ser verificado no caso concreto, pelos Tribunais, com auxílio técnico. BENJAMIN, Antônio Herman V.; MARQUES, Cláudia Lima; BESSA, Leonardo Roscoe. Manual de direito do consumidor, cit., p. 121.

${ }^{162}$ Id. Ibid., p. 120.

${ }^{163} \mathrm{O}$ caso do medicamento Contergan, cujo nome comercial no Brasil é Talidomida está detalhado no último capítulo do trabalho.
} 


\subsubsection{Periculosidade adquirida}

A periculosidade adquirida está presente nos casos em que o produto que não é normalmente perigoso, mas, passa a apresentar risco a bem jurídico do consumidor em virtude da existência de um vício de qualidade por insegurança ou defeito. Este vício pode decorrer de uma série de fatores, que podem ocorrer desde a concepção do produto até sua comercialização, passando por sua fabricação ${ }^{164}$.

A produção e distribuição em massa tornam impossível, na prática, a inocorrência de defeitos, ainda que eventuais. Por maiores que sejam os cuidados, por mais fieis que sejam os cumprimentos dos protocolos, oriundos da administração pública ou da própria empresa, sempre haverá margem para a ocorrência do defeito.

A principal característica do produto dotado de periculosidade adquirida é a imprevisibilidade, para o consumidor, do seu potencial lesivo. Nestes casos, não há advertência que seja suficientemente eficiente para eliminar a periculosidade do produto ${ }^{165}$.

De acordo com a causa do defeito apresentado pelo produto, as três modalidades básicas de periculosidade adquirida são decorrentes de: defeito de concepção; defeito de fabricação; defeito de comercialização.

\subsubsection{O produto defeituoso}

Conforme redação do artigo $12, \S 1^{\circ}$ do Código de Defesa do Consumidor:

O produto é defeituoso quando não oferece a segurança que dele legitimamente se espera, levando-se em consideração as circunstâncias relevantes, entre as quais:

I - sua apresentação;

II - o uso e os riscos que razoavelmente dele se esperam;

III - a época em que foi colocado em circulação.

\footnotetext{
${ }^{164}$ SANSEVERINO, Paulo de Tarso Vieira. op. cit., p. 140.

${ }^{165}$ BENJAMIN, Antônio Herman V.; MARQUES, Cláudia Lima; BESSA, Leonardo Roscoe. Manual de direito do consumidor, cit., p. 120.
} 
O CDC acompanha quase que literalmente a redação da Diretiva 85/374/CEE ${ }^{166}$ que, em seu artigo $6^{\circ}$ define que o "produto é defeituoso quando não oferece a segurança que se pode legitimamente esperar, tendo em conta todas as circunstâncias, tais como: (a) apresentação do produto; (b) a utilização do produto que se pode razoavelmente esperar; (c) o momento de entrada em circulação do produto.

Em seu artigo 18, § $6^{\circ}$, o CDC elenca como produtos impróprios ao uso e consumo: I - os produtos cujos prazos de validade estejam vencidos; II - os produtos deteriorados, alterados, adulterados, avariados, falsificados, corrompidos, fraudados, nocivos à vida ou à saúde, perigosos ou, ainda, aqueles em desacordo com as normas regulamentares de fabricação, distribuição ou apresentação;

III - os produtos que, por qualquer motivo, se revelem inadequados ao fim a que se destinam.

Embora haja a previsão expressa em norma a esse respeito, o fato é que os produtos com prazo de validade vencido nem sempre trazem o potencial de efetivamente expor à perigo a saúde do consumidor. Há, portanto, necessidade de comprovação pericial acerca do potencial nocivo do produto.

Os produtos relacionados no artigo $18, \S 6^{\circ}$, II, por sua vez, também, nem sempre trazem o potencial de perigo. Um alimento deteriorado representa, evidentemente, efetivo perigo à saúde, à integridade física, ou, até mesmo, à vida do consumidor. Uma peça de vestuário falsificada, por outro lado, não representa qualquer risco a tais bens jurídicos.

Do mesmo modo, os produtos que, "por qualquer motivo, se revelem inadequados ao fim a que se destinam" tampouco são necessariamente perigosos ao bem estar do consumidor, devendo, por isso, ser analisados caso a caso. A expressão qualquer motivo, por englobar toda e qualquer espécie de motivo, e, sendo assim, acaba tornando a lei excessivamente aberta, correndo-se o risco de, por exemplo, entendermos como "produto em condições impróprias ao consumo" e, portanto, típica conforme o artigo $7^{\circ}$, IX, da Lei 8.137/90, a conduta de expor a venda, conforme exemplo de ALBERTO ZACHARIAS TORON $^{167}$, um absorvente incapaz de suportar um fluxo menstrual excessivo. $O$ fato de o

\footnotetext{
${ }^{166}$ Esta diretiva trata da responsabilidade civil decorrente dos produtos defeituosos no âmbito da União Europeia, procurando harmonizar as legislações dos Estados-membros.

${ }^{167}$ TORON, Alberto Zacharias. Aspectos penais da proteção ao consumidor. Revista Brasileira de Ciências Criminais, São Paulo, v. 3, n. 11, p.89, jul./set. 1995.
} 
fluxo ser excessivo é considerado anormal, mas, enquadra-se, sem dúvidas, em "qualquer motivo".

É importante lembrar que este elenco de motivos que tornam o produto impróprio ao uso e consumo está inserido num sistema de responsabilidade objetiva ${ }^{168}$ previsto pelo CDC. A responsabilidade penal, por óbvio, deve ser analisada à luz da responsabilidade subjetiva, sob pena de inconstitucionalidade.

A responsabilidade penal pelo produto, portanto, não pode ser tão abrangente quanto a responsabilidade civil e, sendo assim, não será aplicada a todo caso de dano decorrente de produtos defeituosos, mas apenas a uma pequena gama e após a aferição cuidadosa de uma série de critérios.

É adequado que a responsabilidade penal pelo produto seja restrita aos casos de perigo e danos causados por produtos defeituosos ${ }^{169}$, ou seja, por aqueles produtos que não ofereçam a segurança que deles legitimamente se espera, considerando sua apresentação, o uso e os riscos que dele razoavelmente se espera e a época em que foi colocado em circulação, conforme artigo 12 do Código de Defesa do Consumidor.

A responsabilidade penal pelo produto, deste modo, deve ser limitada aos casos em que haja, pelo menos, risco à segurança do consumidor, especificamente, em relação aos bens jurídicos saúde, integridade física e vida, sendo as ameaças e efetivas lesões à propriedade do consumidor, reparáveis por meio de responsabilidade civil.

Segundo o que se extrai do artigo 12 do CDC, de um modo geral, o produto deve atender ao critério da "legítima expectativa", ou seja, é necessário que o produto colocado no mercado de consumo se coadune com o que os consumidores dele legitimamente esperam. Entende-se por expectativa legítima aquela que seja razoável de acordo com o estágio técnico e as condições econômicas da época ${ }^{170}$.

Seja qual for a origem do defeito, o produto passará a apresentar, em sua decorrência, um potencial lesivo que, normalmente, não possui, sendo, por isso,

\footnotetext{
${ }^{168} \mathrm{O}$ caput do artigo 12 do $\mathrm{CDC}$ determina que fornecedores respondam pelos danos causados em decorrência do defeito de seus produtos, "independentemente da existência de culpa".

${ }^{169}$ Para o CDC, o chamado "fato do produto" ocorre nos casos em que o produto coloca em risco a segurança de bem jurídico do consumidor, seja ele saúde, vida, integridade física ou propriedade (art. 12). O fato do produto é, portanto, o dano causado por um produto a um bem jurídico cujo titular é o consumidor. Já o "vício do produto" é referente à menor valia do produto em si, não afetando a segurança do consumidor. $\mathrm{O}$ vício do produto é a diminuição de seu valor ou mesmo sua impropriedade ou inadequação ao consumo a que se destinam (art. 18).

${ }^{170}$ BENJAMIN, Antônio Herman V.; MARQUES, Cláudia Lima; BESSA, Leonardo Roscoe. Manual de direito do consumidor, cit., p. 118.
} 
inesperada. É essencial, para a apuração da responsabilidade pelo vício, saber onde está sua causa ${ }^{171}$. Em qual fase do processo produtivo, desde o planejamento do produto até sua disponibilização ao mercado consumidor, e devido a qual ou a quais razões o produto, a princípio seguro, teve a ele incorporada a possibilidade de causar dano.

Segundo a classificação adotada por VASCONCELLOS E BENJAMIN ${ }^{172}$, são as seguintes, as espécies de vícios de qualidade por insegurança ou defeitos que pode apresentar um produto: defeitos de concepção, defeitos de fabricação e defeitos de comercialização.

A seguir, será feita a análise de cada um deles, apontando-se os possíveis responsáveis, nem sempre penalmente, por sua ocorrência.

\subsubsection{Defeitos de concepção}

$\mathrm{O}$ artigo 12, caput, do $\mathrm{CDC}$, traz a previsão dessa modalidade de vício ao mencionar defeitos decorrentes de projeto e fórmulas.

O defeito de concepção, também denominado defeito de projeto ou defeito de criação ocorrem na fase de planejamento do produto. São erros de design, de formulação, de cálculos, de escolha de materiais (sejam eles inadequados, nocivos à saúde ou de qualidade inferior à recomendada ${ }^{173}$ ), da especificação da montagem ou de qualquer outra fase do projeto propriamente dito.

Suas características principais são a manifestação em todos os produtos fabricados, trazendo, por isso, enorme potencial lesivo; a dificuldade de previsão estatística; a inevitabilidade, em especial, nos casos em que o conhecimento técnico não seja capaz de antevê-lo ${ }^{174}$.

\footnotetext{
${ }^{171}$ Vasconcellos e Benjamin chama a atenção para o fato de que tal verificação é importante para que sejam apresentadas soluções ao problema. BENJAMIN, Antônio Herman V.; MARQUES, Cláudia Lima; BESSA, Leonardo Roscoe. Manual de direito do consumidor, cit., p. 120.

${ }^{172}$ Id., loc. cit.

${ }^{173}$ DENARI, Zelmo. Da responsabilidade pelo fato do serviço. In: GRINOVER, Ada Pellegrini; BENJAMIN, Antônio Herman de Vasconcellos e; FINK, Daniel Roberto; FILOMENO, José Geraldo Brito; WATANABE, Kazuo; NERY JÚNIOR, Nelson; DENARI, Zelmo. op. cit., p. 184.

${ }^{174}$ BENJAMIN, Antônio Herman V.; MARQUES, Cláudia Lima; BESSA, Leonardo Roscoe. Manual de direito do consumidor, cit., p. 128.
} 
Essa modalidade de defeitos atinge toda a linha de produção ${ }^{175}$, gera a necessidade de recall e pode gerar o dever de retirada do produto do mercado de consumo, previsto no artigo $10 \S 1^{\circ}$ do CDC.

Por tratar-se de erro técnico, deverá responder por ele, em geral, aquele que for o responsável técnico pelo produto, seja ele um engenheiro, um químico, um designer ou qualquer outro profissional que, no exercício da profissão, em virtude de seu conhecimento técnico, para o qual está legitimamente habilitado, responda legalmente pela concepção do produto $^{176}$. Haverá exceção a esta regra nos casos em que o responsável técnico alertar a direção da empresa a respeito do risco e esta, seja individualmente, seja através de órgão colegiado, decidir, ainda assim, pela colocação do produto no mercado de consumo ${ }^{177}$.

Ao tomar conhecimento da periculosidade inerente ao produto já distribuído ao consumo o fornecedor deve cumprir o dever de informar. Se assim não proceder, além do defeito de concepção será agregado ao produto o defeito de comercialização por ausência de informação adequada ${ }^{178}$.

$\mathrm{O}$ artigo $12, \S 1^{\circ}$, III do $\mathrm{CDC}$ ao elencar "a época em que foi colocado em circulação" como uma das circunstâncias que devem ser consideradas ao aferir se o produto atende a legítima expectativa de segurança do consumidor, verifica se o desconhecimento do risco era compatível com o as informações da comunidade científica naquele momento. $\mathrm{O}$ fornecedor que desconheça um fato que é cientificamente divulgado e, por esta razão, coloca produto potencialmente lesivo no mercado de consumo, está, no mínimo, agindo culposamente. Espera-se, ainda, pela mesma razão, que após a colocação do produto no mercado de consumo, o fornecedor continue o monitorando para verificar eventuais defeitos que não tenham sido detectados até então.

Para ser cogitada a responsabilidade penal, no caso dos defeitos de concepção, é necessário, minimamente, que o fabricante não haja cumprido seus deveres objetivos de cuidado, respeitado a legislação específica, bem como, as regras técnicas (daí incluídos os

\footnotetext{
${ }^{175}$ SANSEVERINO, Paulo de Tarso Vieira. op. cit., p. 148.

${ }^{176} \mathrm{Um}$ erro de concepção bastante ilustrativo é o do brinquedo Acqua Dots da Indútria Canadense Spin Master, descrito no último capítulo desta dissertação, que consistia em pequenas esferas que deveriam ser molhadas, mas que, em contato com a água, liberavam a droga GHB, o ecstasy líquido.

${ }^{177}$ Este foi, aparentemente, o caso da Indústria VolksWagen, no incidente do automóvel FOX descrito no final do trabalho.

${ }^{178}$ BENJAMIN, Antônio Herman V.; MARQUES, Cláudia Lima; BESSA, Leonardo Roscoe. Manual de direito do consumidor, cit., p. 131.
} 
Manuais de Boas Práticas de Fabricação) no processo de fabricação e comercialização de seus produtos.

Nunca é demais lembrar que a responsabilidade penal é sempre subjetiva, devendo ser aferidos, além de dolo ou culpa na conduta do agente, uma série de outros critérios para que possa ser imputada a alguém. Isso quer dizer que, para que se possa começar a cogitar imputar-se a alguém a responsabilidade penal pelo produto, esta pessoa deve, necessariamente, ter agido dolosa ou culposamente para a ocorrência do defeito.

Deste modo, a responsabilidade penal pelo produto, se houver, somente poderá ser aferida após a constatação de que: (a) da colocação do produto no mercado de consumo decorre lesão ou perigo de lesão à saúde do consumidor; (b) há uma (ou mais de uma) conduta individualizável, dolosa ou culposa, que gerou uma periculosidade do produto em descompasso com a legítima expectativa do consumidor.

Necessário, ainda, se faz, neste ponto, o esclarecimento sobre questão bastante complexa e controversa que diz respeito aos defeitos decorrentes do chamado "risco de desenvolvimento", aqui entendido como subespécie dos defeitos de concepção ${ }^{179}$. Isto é, importa estabelecer se são dignos de resposta penal danos, segundo FÁBIO ULHOA COELHO "decorrentes de efeito do fornecimento incognoscível no momento de sua introdução no mercado de consumo" ${ }^{180}$. Surgem em decorrência da inexistência, à época da concepção e colocação do produto no mercado de consumo, de informações científicas suficientes sobre seu potencial lesivo ${ }^{181}$. Neste caso, os riscos inerentes ao produto eram desconhecidos pela ciência e pela técnica e, por isso, imprevisíveis. Somente após a colocação do produto no mercado é que se nota sua periculosidade ${ }^{182}$.

$\mathrm{O}$ risco de desenvolvimento coloca em lados opostos, no que diz respeito à responsabilidade civil, interesses que precisam ser sopesados: o interesse coletivo pelo desenvolvimento científico e tecnológico e o direito à indenização por acidente de

\footnotetext{
${ }^{179}$ Posição diversa apresenta FÁBIO ULHOA COELHO. Entende o autor que, neste caso, não há a presença do chamado fornecimento perigoso nem de defeito de concepção, uma vez que este só seria possível nos casos em que se pode conhecer no momento do fornecimento do produto, por intermédio de pesquisa, a sua periculosidade.

${ }^{180}$ COELHO, Fábio Ulhoa. O empresário e os direitos do consumidor: o cálculo empresarial na interpretação do Código de Defesa do Consumidor. São Paulo: Saraiva, 1994. p. 82.

${ }^{181}$ BENJAMIN, Antônio Herman V.; MARQUES, Cláudia Lima; BESSA, Leonardo Roscoe. Manual de direito do consumidor, cit.

${ }^{182}$ HERMAN BENJAMIM assevera que a fase final de testes de qualquer produto ocorre com a sua colocação no mercado de consumo e utilização em grande escala e que, na realidade, em muitos casos, os consumidores são cobaias dos produtos. BENJAMIN, Antônio Herman V.; MARQUES, Cláudia Lima; BESSA, Leonardo Roscoe. Manual de direito do consumidor, cit., p. 131-132.
} 
consumo. Isso ocorre, pois, a sociedade empresária, por definição, é aquela que visa o lucro, e, sendo assim, seus agentes tomam decisões que sejam a ela economicamente interessantes. Por isso, se houver a possibilidade de que um produto, por causa do seu risco de desenvolvimento realizar um resultado lesivo apto a gerar a obrigação de indenizar civilmente suas vítimas, o quantum indenizatório será levado em consideração na hora de se decidir se o referido produto será colocado no mercado ou se será objeto de mais pesquisas ou, ainda, se será colocado de lado por aquela empresa específica por ausência de interesse econômico.

Antes de colocar um produto no mercado de consumo, o fornecedor deve conhecer o risco por ele oferecido. Esse conhecimento acerca do desenvolvimento científico e tecnológico pode vir de departamento de pesquisa existente na própria empresa fornecedora, bem como, daquele mundialmente compartilhado pela comunidade científica $^{183}$.

A Diretiva 85/374 da União Europeia, que trata da responsabilidade pelo produto, exclui, em seu artigo $7^{\circ}$, e, a responsabilidade do fornecedor quando o estado dos conhecimentos científicos e técnicos no momento da colocação do produto no mercado de consumo não permitir detectar a existência do defeito. $\mathrm{O}$ artigo $12 \S 1^{\circ}$ do Código de Defesa do Consumidor, por sua vez, estabelece como produto defeituoso aquele que não oferece a segurança que dele legitimamente se espera, levando-se em consideração, dentre outros fatores, a época em que foi colocado em circulação. $\mathrm{O} \S 3^{\circ}$ do referido artigo exclui a responsabilidade do fornecedor apenas quando provar: que não colocou o produto no mercado; que, embora haja colocado o produto no mercado, o defeito inexiste; a culpa exclusiva do consumidor ou de terceiro. Ou seja, o CDC não prevê taxativamente o risco de desenvolvimento como excludente de responsabilidade civil pelos danos causados pelo produto. HERMAN BENJAMIN entende que a ordem jurídica brasileira não admite tal exclusão por ter incorporado a tese do risco pela atividade ${ }^{184}$. FÁBIO ULHOA COELHO, por outro lado, analisa a dicção do artigo 10 que veda ao fornecedor a colocação no mercado de consumo de produto que sabe ou deveria saber apresentar alto grau de nocividade ou periculosidade à saúde ou segurança. Entende o referido autor que não se pode entender que o Código está ordenando que o fornecedor saiba aquilo que é desconhecido pela ciência no estágio de desenvolvimento científico no momento do

\footnotetext{
${ }^{183}$ COELHO, Fábio Ulhoa. op. cit., p. 82.

${ }^{184}$ BENJAMIN, Antônio Herman V.; MARQUES, Cláudia Lima; BESSA, Leonardo Roscoe. Manual de direito do consumidor, cit.
} 
fornecimento do produto, pois, isso seria obrigar ao impossível. Ressalva, no entanto, que o $\S 1^{\circ}$ determina ao fornecedor o dever de informar imediatamente às autoridades competentes e aos consumidores, mediante anúncios publicitários, acerca da periculosidade apresentada pelo produto da qual tenha conhecimento após sua introdução no mercado de consumo, mas não prevê a obrigação de indenizar eventuais danos ${ }^{185}$. Importa destacar que o artigo 64 do CDC prevê a pena de detenção de seis meses a dois anos e multa para quem descumprir a obrigação de informar a respeito de nocividade ou periculosidade de produtos cujo conhecimento seja posterior à sua colocação no mercado, pena que estende, em seu parágrafo único, a quem deixar de retirar do mercado, imediatamente quando determinado pela autoridade competente, os referidos produtos nocivos ou perigosos.

Deve-se, ainda, esclarecer que o conhecimento referido pelo CDC ao falar em periculosidade ou nocividade do produto à saúde ou segurança que o fornecedor "sabe ou deveria saber", tem como parâmetro o desenvolvimento do conhecimento humano especializado pelo chamado estado da arte ${ }^{186}$, ou seja, na definição de FÁBIO ULHOA COELHO, "o conjunto de conhecimentos acumulados pelos cientistas e especialistas no mundo todo, ligados ao meio acadêmico ou empresarial, acerca dos efeitos que determinados processos, substâncias, formas ou mecanismos em produtos e serviços pode acarretar à saúde ou à segurança das pessoas a eles expostas" ${ }^{187}$.

Cumprido o dever do fornecedor de estar a par do estado da arte no que diz respeito aos produtos que coloque no mercado, especialmente, no que diz respeito a seu potencial nocivo ou lesivo, não há que se falar em responsabilidade penal. Se tal dever não for cumprido, pode-se falar, pelo menos em responsabilidade penal a título de culpa.

\subsubsection{Defeitos de fabricação}

Outra modalidade de defeito prevista pelo Código de Defesa do Consumidor, também pelo caput do artigo 12, é o defeito de fabricação. O CDC se refere a este vício ao falar em defeitos decorrentes de fabricação, construção, montagem, manipulação e acondicionamento.

\footnotetext{
${ }^{185}$ COELHO, Fábio Ulhoa. op. cit., p. 86.

${ }^{186}$ Id. Ibid., p. 84.

${ }^{187}$ COELHO, Fábio Ulhoa. op. cit., p. 87.
} 
Também chamados de defeitos de execução, podem decorrer da construção ou do desenvolvimento do produto. O projeto é correto, mas sua execução é errada em razão de fatores diversos, que podem ser falhas humanas ou mecânicas.

Os defeitos de execução, ao contrário do que acontece com os defeitos de concepção, não atingem toda a produção, mas apenas parte dela, uma série do produto. Ou seja, trata-se de defeito capaz de causar dano a uma parcela limitada de consumidores daquele produto, somente aqueles que consumirem os produtos da série afetada. Não possuem o caráter de universalidade presente nos defeitos de concepção ${ }^{188}$. Outra diferença que apresentam é a possibilidade de previsão estatística de sua ocorrência, o que facilita a contratação de seguro ${ }^{189}$.

Nesta espécie de vício também estão englobados os defeitos decorrentes de armazenamento ou acondicionamento, bem como, os produtos perfeitos que acabam contaminados por corpos estranhos ${ }^{190}$.

A presença desta modalidade de defeito gera para o fornecedor o dever de realizar o recall, mas, apenas da série que foi afetada pela falha na fabricação.

É um defeito inevitável, devido ao processo produtivo em massa. Pode-se reduzir bastante sua incidência, por meio de sistemas rigorosos de controle de qualidade, mas não chegar a zero. Mesmo porque, quanto mais rigoroso o controle de qualidade, maior será o custo do produto.

As agências reguladoras e os Manuais de Boas Práticas de Fabricação dos mais diversos produtos fixam normas e regras técnicas que devem ser seguidas rigorosamente pelos produtores. Não se pode falar em responsabilidade penal do produtor (ou de qualquer funcionário responsável por determinada etapa de produção) que, embora siga todas as regras previstas nestes manuais, tenha deixado chegar ao mercado um produto impróprio para o consumo. Mas, somente, daquele que tenha deixado de observá-las, dentro da sua esfera de responsabilidades dentro da cadeia empresarial, criando a possibilidade ou aumentando a probabilidade da incidência do referido defeito.

\footnotetext{
${ }^{188}$ SANSEVERINO, Paulo de Tarso Vieira. op. cit., p. 149.

${ }^{189}$ BENJAMIN, Antônio Herman V.; MARQUES, Cláudia Lima; BESSA, Leonardo Roscoe. Manual de direito do consumidor, cit., p. 127.

${ }^{190}$ Id., loc. cit.
} 


\subsubsection{Defeitos de comercialização}

Quando o CDC fala em defeito de produto decorrente de apresentação, acondicionamento $^{191}$ ou de informações insuficientes ou inadequadas sobre sua utilização e riscos, está se referindo aos defeitos de comercialização.

Os defeitos de informação decorrem da insuficiência ou equívoco da informação prestada ao consumidor quanto à utilização do produto. $\mathrm{O}$ fornecedor, neste caso, deixa de informar ao consumidor acerca dos riscos inerentes ao produto ${ }^{192}$. Um produto perfeito, deste modo, torna-se um produto dotado de vício de qualidade por insegurança em decorrência da violação ao dever de informação.

O defeito de informação, ao contrário dos defeitos de concepção e execução que são intrínsecos ao produto, é, a ele, extrínseco e causado pela falha quanto ao dever que o fornecedor tem de informar ao consumidor suas reais e efetivas características, em decorrência da necessária presença de transparência e lealdade entre as partes das relações de consumo ${ }^{193}$.

O dever do fornecedor de informar acerca das características do produto, dentre as quais, sua periculosidade, está garantido entre os direitos básicos do consumidor, e é previsto no artigo $6^{\circ}$, III do CDC, que prevê o direito à "informação adequada e clara sobre os diferentes produtos e serviços, com especificação correta de quantidade, características, composição, qualidade e preço, bem como sobre os riscos que apresentem".

A informação adequada deve, portanto, acompanhar o produto. Se, no entanto, o fabricante só souber da existência da periculosidade após a distribuição ao mercado de consumo deverá, por força do artigo 10 do referido Código, cumprir seu dever de informar posteriormente, imediatamente após tomar conhecimento de sua periculosidade, comunicando "às autoridades competentes e aos consumidores mediante anúncios publicitários".

\footnotetext{
${ }^{191} \mathrm{O}$ acondicionamento inadequado pode decorrer da fabricação ou da comercialização.

${ }^{192}$ BENJAMIN, Antônio Herman V.; MARQUES, Cláudia Lima; BESSA, Leonardo Roscoe. Manual de direito do consumidor, cit., p. 128.

${ }^{193}$ SANSEVERINO, Paulo de Tarso Vieira. op. cit., p. 150.
} 
Levando-se em conta a fase de comercialização de produtos, podemos constatar, ainda, a presença de produtos anônimos, mal identificados e mal conservados ${ }^{194}$. Civilmente, o comerciante é o responsável por danos decorrentes dessas três categorias de produtos.

Os produtos anônimos são aqueles disponibilizados ao consumidor sem que seja possível identificar sua origem. Nos supermercados, por exemplo, percebe-se a presença de frutas, legumes e verduras dos quais se desconhece o fornecedor ${ }^{195}$. No caso dos produtos mal identificados há, também, dúvidas quanto a sua procedência. Em ambas as situações o comerciante viola regra a respeito das práticas comerciais, prevista no artigo 31 do CDC, que regula a oferta ${ }^{196}$. Para o Direito Civil o comerciante assume a responsabilidade do fornecedor diante de dano causado pelo produto. No caso da responsabilidade penal, há que se verificar a presença de dolo ou culpa do comerciante pelo perigo ou dano causado a bem jurídico do consumidor.

Os produtos perecíveis ${ }^{197}$ mal conservados, por sua vez, podem acarretar responsabilidade penal dos fornecedores ou comerciantes. A Lei $\mathrm{n}^{\circ} 8.137 / 90$, em seu artigo $7^{\circ}$, IX, tipifica a conduta de "vender, ter em depósito para vender ou expor à venda ou, de qualquer forma, entregar matéria-prima ou mercadoria, em condições impróprias ao consumo". O artigo $18 \S 6^{\circ}$, II, do CDC, a seu tempo, elenca como produto em condições impróprias ao consumo “os produtos deteriorados (...), nocivos à vida ou à saúde, perigosos ou, ainda, aqueles em desacordo com as normas regulamentares de fabricação, distribuição ou apresentação". Os produtos "perecíveis mal conservados" são, no mínimo, deteriorados. É necessário, no entanto, que seja aferida a responsabilidade subjetiva pelo perecimento do produto para que haja a possibilidade de responsabilização penal.

\footnotetext{
${ }^{194}$ BENJAMIN, Antônio Herman V.; MARQUES, Cláudia Lima; BESSA, Leonardo Roscoe. Manual de direito do consumidor, cit., p. 136.

${ }^{195}$ Id., loc. cit.

${ }^{196}$ CDC, Art. 31. A oferta e apresentação de produtos ou serviços devem assegurar informações corretas, claras, precisas, ostensivas e em língua portuguesa sobre suas características, qualidades, quantidade, composição, preço, garantia, prazos de validade e origem, entre outros dados, bem como sobre os riscos que apresentam à saúde e segurança dos consumidores.

${ }^{197}$ Produtos perecíveis são aqueles que "demandam condições especiais para sua conservação sendo insuficientes as condições ambientais normais. BENJAMIN, Antônio Herman V.; MARQUES, Cláudia Lima; BESSA, Leonardo Roscoe. Manual de direito do consumidor, cit., p. 136.
} 


\subsection{O Direito como tutela às relações de consumo e ao consumidor: principais diplomas normativos}

A tutela do consumo e do consumidor no Brasil é exercida pela Lei $\mathrm{n}^{\circ} .8 .078$ de 11 de setembro de 1990, o Código de Defesa do Consumidor e pela Lei $n^{\circ} .8 .137$ de 27 de dezembro de 1990 e, de forma indireta ou reflexa por diversos instrumentos e normas nas esferas federal, estadual e municipal. A seguir, elencamos os principais instrumentos e diplomas normativos que visam a proteção das relações de consumo e do consumidor no que tange à colocação de produtos no mercado. Além da Constituição Federal e de Tratados Internacionais, o rol se restringe às regras editadas pela União, ou seja, normas federais. Limita-se, ainda, às normas genéricas, evitando especializações que tornariam o trabalho infinito e, portanto, inexequiível.

\subsubsection{A proteção conferida constitucionalmente}

A Constituição da República Federativa do Brasil de 1988 prevê em diferentes dispositivos a necessidade de uma proteção específica ao consumidor, inclusive em seu art. $5^{\circ}$, que trata dos Direitos Fundamentais ${ }^{198}$, demonstrando a importância dada pelo ordenamento jurídico a este sujeito vulnerável no âmbito das relações de consumo. Determina a carta constitucional:

Art. $5^{o}$, XXXII - o Estado promoverá, na forma da lei, a defesa do consumidor;

Art. 24, VIII Compete à União, aos Estados e ao Distrito Federal legislar concorrentemente sobre:

(...)

VIII - responsabilidade por dano ao meio ambiente, ao consumidor, a bens e direitos de valor artístico, estético, histórico, turístico e paisagístico;

\footnotetext{
${ }^{198} \mathrm{Em}$ 1968, em Teerã, durante a I Conferência Mundial dos Direitos Humanos, declarou-se a impossibilidade da plena efetivação dos direitos civis e políticos sem a efetividade dos direitos econômicos, sociais e culturais. BONAVIDES, Paulo. Curso de direito constitucional. São Paulo: Malheiros Ed., 2000. p. 360. Por esta razão, a proteção ao consumidor é, hoje, entendida como direito fundamental pertencente à terceira dimensão ou direitos de fraternidade ou solidariedade que são aqueles referentes à coletividade, de titularidade difusa ou coletiva. DE LUCCA, Newton. Direito do consumidor. São Paulo: Quartier Latin, 2003. p. 426.
} 
Art. 170. A ordem econômica, fundada na valorização do trabalho humano e na livre iniciativa, tem por fim assegurar a todos existência digna, conforme os ditames da justiça social, observados os seguintes princípios:

$V$ - defesa do consumidor;

ADCT Art. 48. O Congresso Nacional, dentro de cento e vinte dias da promulgação da Constituição, elaborará código de defesa do consumidor.

\subsubsection{A tutela internacional}

A vulnerabilidade do consumidor se tornou ainda mais acentuada nas últimas décadas, devido aos processos de globalização e de integração econômica, especialmente, pelas diferenças culturais e idiomáticas ${ }^{199}$. Podendo adquirir produtos oriundos de países localizados em qualquer parte do mundo, o consumidor se viu exposto a novos riscos sem a possibilidade de alcançar um instituto jurídico capaz de protegê-lo adequadamente diante de tamanha diversidade de jurisdição.

A tutela do consumidor recebeu, em decorrência da complexidade de seu alcance, tratamento específico na esfera internacional, por intermédio de tratados ${ }^{200}$. Assembléia Geral da ONU, em 10 de abril 1985, editou a Resolução nº. 39/248 ${ }^{201}$, versando sobre a tutela do consumidor, positivando, internacionalmente, o princípio da vulnerabilidade do consumidor. A Resolução tem por objetivos, dentre outros: auxiliar os

\footnotetext{
${ }^{199}$ Um episódio que ilustra bem as referidas diferenças culturais ocorreu em 2007, na Suíça, quando a empresa automobilística Volkswagen foi alvo de uma série de matérias jornalísticas produzidas pela imprensa local, deflagradas pela percepção de que o modelo do automóvel Fox produzido no Brasil e exportado para a Europa possuía muitos componentes de segurança que eram inexistentes nos modelos destinados ao consumidor brasileiro. A Euroconsumer, central de proteção ao consumidor da União Europeia, realizou testes com ambos os modelos e aferiu esta disparidade. A postura da companhia pode ser entendida, de acordo com as reportagens, com o argumento de que seria decorrente da diferença de demanda entre Brasil e Europa. Ou seja, o automóvel europeu é muito mais seguro que o brasileiro, pois, enquanto o consumidor brasileiro buscaria preço e possibilidade de financiamento do pagamento, o consumidor europeu procura segurança. Informação em EUROPA. Europa Commission. Consumer Affairs. Disponível em: <http://ec.europa.eu/consumers/ecc/index_en.htm>, e TV Suíça denuncia carro da Volkswagen do Brasil. Swissinfo, 06 mar. 2007. Disponível em: $<$ http://www.swissinfo.ch/por/Capa/Archive/TV_Suica_denuncia_carro_da_Volkswagen_do_Brasil.html?c id=5761928>. Acesso em: 22 nov. 2010.

${ }^{200}$ A Emenda Constitucional $n^{\circ} .45$ incluiu o $\S 3^{\circ}$ ao artigo $5^{\circ}$ da Constituição de 1988, determinando que "os tratados e convenções internacionais sobre direitos humanos que forem aprovados, em cada Casa do Congresso Nacional, em dois turnos, por três quintos dos votos dos respectivos membros, serão equivalentes às emendas constitucionais".

${ }^{201}$ UNITED NATIONS. General Assembly. A/RES/39/248 - 16 April 1985. Disponível em: $<$ http://www.un.org/documents/ga/res/39/a39r248.htm>.
} 
Estados na efetiva proteção dos consumidores; promover a atuação ética daqueles que exercem a produção e distribuição de bens e serviços aos consumidores; apoiar os países na contenção de práticas comerciais abusivas por empresas nacionais e internacionais. Entende como necessidades legítimas a serem atendidas pelas diretrizes: a) a proteção dos consumidores contra os riscos à sua saúde e segurança; b) a promoção e a proteção dos interesses econômicos dos consumidores; c) o acesso dos consumidores à informação adequada que lhes permita fazer escolhas informadas de acordo com os desejos e necessidades individuais; d) a educação dos consumidores; e) a disponibilidade de reparação eficaz dos consumidores; f) a liberdade para formar consumidores e outros grupos ou organizações relevantes e a oportunidade de tais organizações para apresentarem seus pontos de vista em processos decisórios que lhes digam respeito.

Em relação às normas de segurança e qualidade de produtos, orienta que os governos devem formular ou promover sua elaboração e aplicação e lhes dar a devida publicidade e que devem ser periodicamente revistas. Aponta, ainda, que quando a norma interna for menos protetiva que a internacional por conta das condições econômicas locais, deve-se procurar elevar o nível de tutela o mais rapidamente possível. E mais: que os Governos devem estimular e garantir a disponibilidade de instalações para testar e certificar a qualidade, segurança e desempenho dos produtos.

Em 15 de dezembro de 2000, foi assinada em Florianópolis pelos Presidentes dos Estados-Membros do Mercosul (Argentina, Brasil, Paraguai e Uruguai) a Declaração Presidencial dos Direitos Fundamentais dos Consumidores do Mercosul ${ }^{202}$, considerando o compromisso de harmonizar progressivamente suas legislações e declarando que a defesa do consumidor contempla diversos direitos fundamentais, dentre os quais: direito à proteção eficaz da vida, da saúde e da segurança do consumidor e do meio ambiente contra os riscos provocados por práticas no fornecimento de produtos e serviços; ao equilíbrio nas relações de consumo, assegurado o respeito aos valores de dignidade e lealdade, com fundamento na boa fé, conforme a legislação vigente em cada Estado Parte; ao fornecimento de serviços, tanto públicos como privados, e produtos em condições adequadas e seguras; à informação suficiente, clara e veraz; à facilitação do acesso aos órgãos judiciais e administrativos e a meios alternativos de solução de conflitos, mediante

\footnotetext{
${ }^{202}$ MERCOSUL. XIX Reunião do Conselho do Mercado Comum. Declaração Presidencial dos Direitos Fundamentais dosm Consumidores do Mercosul. Disponível em: <http://www2.mre.gov.br/xixmercosul/Textos/dec-direitosfund.htm>.
} 
procedimentos ágeis e eficazes, para a proteção dos interesses individuais e difusos dos consumidores.

Enquanto na União Europeia a tutela consumerista tem como foco $\mathrm{o}$ desenvolvimento econômico, a pauta da discussão no Mercosul foi estabelecida pela preocupação com a proteção jurídica dos indivíduos ${ }^{203}$. O Protocolo de Santa Maria de 1996, que trata sobre a jurisdição internacional em matéria de relações de consumo mostra essa tendência quando, por exemplo, declara especificamente a necessidade de dar proteção ao consumidor e a importância de se adotarem regras comuns sobre jurisdição internacional em matéria de relações de consumo derivadas de contratos entre fornecedores de bens ou prestadores de serviço e consumidores ou usuários.

\subsubsection{A defesa infraconstitucional das relações de consumo e do consumidor}

Seguindo a orientação constitucional, o Congresso Nacional publica, em 11 de setembro de 1990, a Lei $\mathrm{n}^{\circ}$. 8078, o Código de Defesa do Consumidor, um microssistema ${ }^{204}$ que tem como orientação primordial a tutela dos direitos do sujeito por ele entendido como vulnerável na relação jurídica em questão: o consumidor.

O CDC procura tutelar as os direitos do consumidor declarando seus direitos, bem como, os deveres daqueles que fornecerão produtos ou serviços. Determina, também, sanções civis, administrativas e penais para aqueles que infringirem tais deveres.

Anda muito bem o Código naquilo que se refere às tutelas civil e administrativa, sendo considerado, neste sentido, como legislação exemplar. No entanto, no tocante à tutela penal o microssistema escorrega, protegendo direitos que prescindem da esfera penal para serem protegidos e se descuidando de outros que necessitam do recurso mais radical de nosso ordenamento jurídico para sua defesa. Não é exagero afirmar, portanto, que a parte penal da Lei $\mathrm{n}^{\circ}$. 8078/90 merece uma completa e profunda reformulação, extirpando normas que afrontam a orientação ultima ratio desse ramo do Direito, e também, incluindo

\footnotetext{
${ }^{203}$ MARQUES, Cláudia Lima. O Código Brasileiro de Defesa do Consumidor e o MERCOSUL: estudos sobre a proteção do consumidor no Brasil e no MERCOSUL. Porto Alegre: Livr. do Advogado, 1994. p. 406-407.

${ }^{204} \mathrm{O}$ CDC é entendido como microssistema pois trata de normas dos mais diversos ramos do Direito, dentre os quais, o Direito Constitucional, Civil, Administrativo, Penal e Processual.
} 
outras que fazem falta na hora de tutelar, efetivamente, bens jurídicos essenciais ao livre desenvolvimento do indivíduo, bem como, do harmônico funcionamento da sociedade.

O artigo 61 do CDC determina que os crimes ali elencados não excluem outros previstos no Código Penal e em leis especiais ${ }^{205}$.

Em 27 de dezembro de 1990, foi publicada e entrou em vigor a Lei $\mathrm{n}^{\circ}$. 8.137 definindo os crimes contra a ordem tributária, econômica e contra as relações de consumo. No que se refere, especificamente, às relações de consumo, a lei apresenta um elenco de crimes no artigo $7^{\circ}$ 206, dentre os quais, no que diz respeito à colocação de produto defeituoso no mercado, destacam-se os seguintes incisos: II - vender ou expor à venda mercadoria cuja embalagem, tipo, especificação, peso ou composição esteja em desacordo com as prescrições legais, ou que não corresponda à respectiva classificação oficial; VII induzir o consumidor ou usuário a erro, por via de indicação ou afirmação falsa ou enganosa sobre a natureza, qualidade do bem ou serviço, utilizando-se de qualquer meio, inclusive a veiculação ou divulgação publicitária; IX - vender, ter em depósito para vender ou expor à venda ou, de qualquer forma, entregar matéria-prima ou mercadoria, em condições impróprias ao consumo. A pena prevista é de detenção de dois a cinco anos ou multa. Nos casos dos incisos II e IX, admite-se a modalidade culposa com a pena de detenção reduzida a um terço e a de multa à quinta parte.

\footnotetext{
${ }^{205} \mathrm{CDC}$, art. 61: "Constituem crimes contra as relações de consumo previstas neste Código, sem prejuízo do disposto no Código Penal e leis especiais, as condutas tipificadas nos artigos seguintes".

206 Art. $7^{\circ}$ Constitui crime contra as relações de consumo: I - favorecer ou preferir, sem justa causa, comprador ou freguês, ressalvados os sistemas de entrega ao consumo por intermédio de distribuidores ou revendedores; II - vender ou expor à venda mercadoria cuja embalagem, tipo, especificação, peso ou composição esteja em desacordo com as prescrições legais, ou que não corresponda à respectiva classificação oficial; III - misturar gêneros e mercadorias de espécies diferentes, para vendê-los ou expô-los à venda como puros; misturar gêneros e mercadorias de qualidades desiguais para vendê-los ou expô-los à venda por preço estabelecido para os demais mais alto custo; IV - fraudar preços por meio de: a) alteração, sem modificação essencial ou de qualidade, de elementos tais como denominação, sinal externo, marca, embalagem, especificação técnica, descrição, volume, peso, pintura ou acabamento de bem ou serviço; b) divisão em partes de bem ou serviço, habitualmente oferecido à venda em conjunto; c) junção de bens ou serviços, comumente oferecidos à venda em separado; d) aviso de inclusão de insumo não empregado na produção do bem ou na prestação dos serviços; V - elevar o valor cobrado nas vendas a prazo de bens ou serviços, mediante a exigência de comissão ou de taxa de juros ilegais; VI - sonegar insumos ou bens, recusando-se a vendê-los a quem pretenda comprá-los nas condições publicamente ofertadas, ou retê-los para o fim de especulação; VII - induzir o consumidor ou usuário a erro, por via de indicação ou afirmação falsa ou enganosa sobre a natureza, qualidade do bem ou serviço, utilizando-se de qualquer meio, inclusive a veiculação ou divulgação publicitária; VIII - destruir, inutilizar ou danificar matéria-prima ou mercadoria, com o fim de provocar alta de preço, em proveito próprio ou de terceiros; IX - vender, ter em depósito para vender ou expor à venda ou, de qualquer forma, entregar matéria-prima ou mercadoria, em condições impróprias ao consumo; Pena - detenção, de 2 (dois) a 5 (cinco) anos, ou multa. Parágrafo único. Nas hipóteses dos incisos II, III e IX pune-se a modalidade culposa, reduzindo-se a pena e a detenção de 1/3 (um terço) ou a de multa à quinta parte.
} 
Como circunstâncias agravantes, a lei apresenta: I - ocasionar grave dano à coletividade; II - ser o crime cometido por servidor público no exercício de suas funções; III - ser o crime praticado em relação à prestação de serviços ou ao comércio de bens essenciais à vida ou à saúde.

O Código Penal também tutela a saúde, a vida e a integridade física do consumidor por meio de diversas normas nele constantes, especialmente, no capítulo referente aos crimes contra a saúde pública, analisadas posteriormente.

\subsubsection{O Sistema Nacional de Vigilância Sanitária}

O Sistema Nacional de Vigilância Sanitária, definido pela Lei nº 9.782 de 26 de janeiro de 1999, é composto no âmbito federal pelo Ministério da Saúde, pela Agência Nacional de Vigilância Sanitária - ANVISA e pelos demais órgãos e entidades do Poder Executivo Federal que tenham área de atuação pertinentes ao sistema. Quando solicitadas pela coordenação do Sistema nacional de Vigilância Sanitária, Os Estados, o Distrito Federal e os Municípios fornecem informações ${ }^{207}$.

De acordo com o art. $6^{\circ}$ da Lei nº $9.782 / 99$, cabe à ANVISA:

"promover a proteção da saúde da população, por intermédio do controle sanitário da produção e da comercialização de produtos e serviços submetidos à vigilância sanitária, inclusive dos ambientes, dos processos, dos insumos e das tecnologias a eles relacionados, bem como o controle de portos, aeroportos e de fronteiras".

A autarquia, subordinada ao Ministério da Saúde, neste sentido, tem a incumbência de "regulamentar, controlar e físcalizar os produtos e serviços que envolvam risco à saúde pública" ${ }^{208}$, respeitando a legislação em vigor.

Ainda conforme a Lei $n^{\circ}$. 9.782/99, são submetidos ao controle e à fiscalização sanitária pela ANVISA os seguintes produtos, de acordo com o $\S 1^{\mathrm{o}}$ do art. $8^{\mathrm{o}}$ : a) medicamentos de uso humano, suas substâncias ativas e demais insumos, processos e tecnologias; b) alimentos, inclusive bebidas, águas envasadas, seus insumos, suas embalagens, aditivos alimentares, limites de contaminantes orgânicos, resíduos de

\footnotetext{
${ }^{207}$ Art. $2^{\text {o }}, \S 1^{\text {o }}$ da Lei $n^{\text {o }} .9 .782$ de 26 de janeiro de 1999.

${ }^{208}$ Lei $n^{\circ} .9 .782$ de 26 de janeiro de 1999 , art. $8^{\circ}$.
} 
agrotóxicos e de medicamentos veterinários; c) cosméticos, produtos de higiene pessoal e perfumes; d) saneantes destinados à higienização, desinfecção ou desinfestação em ambientes domiciliares, hospitalares e coletivos; e) conjuntos, reagentes e insumos destinados a diagnóstico; f) equipamentos e materiais médico-hospitalares, odontológicos e hemoterápicos e de diagnóstico laboratorial e por imagem; g) imunobiológicos e suas substâncias ativas, sangue e hemoderivados; h) órgãos, tecidos humanos e veterinários para uso em transplantes ou reconstituições; i) radioisótopos para uso diagnóstico in vivo e radiofármacos e produtos radioativos utilizados em diagnóstico e terapia; j) cigarros, cigarrilhas, charutos e qualquer outro produto fumígero, derivado ou não do tabaco; $\mathrm{k}$ ) quaisquer produtos que envolvam a possibilidade de risco à saúde, obtidos por engenharia genética, por outro procedimento ou ainda submetidos a fontes de radiação.

Além dos referidos produtos, submetem-se à fiscalização da Agência "as instalações físicas, equipamentos, tecnologias, ambientes e procedimentos envolvidos em todas as fases dos processos de produção dos bens e produtos submetidos ao controle e fiscalização sanitária, incluindo a destinação dos respectivos resíduos" 209, bem como "outros produtos e serviços de interesse para o controle de riscos à saúde da população" ${ }^{210}$.

O Ministério da Saúde e a ANVISA - estabelecem, frequentemente, normas (Portarias e Resoluções) que tem como finalidade regulamentar a colocação de produtos no mercado de consumo, determinando os deveres de cuidado que devem ser observadas pelos fornecedores. Além de múltiplos regulamentos de caráter bastante específicos (e.g. Resolução - RDC n 28, de 28 de março de 2000 que dispõe sobre os procedimentos básicos de Boas Práticas de Fabricação em estabelecimentos beneficiadores de sal destinado ao consumo humano e o roteiro de inspeção sanitária em indústrias beneficiadoras de sal), uma normatização geral.

Embora a ANVISA tenha a atribuição de conceder registro, controlar e fiscalizar toda a gama de produtos acima referidos, preliminarmente, faz isso, apenas, por meio de análise de documentação fornecida pelas empresas que queiram disponibilizá-lo no mercado consumidor, deixando, por isso, os consumidores expostos aos riscos de eventuais impropriedades e disparidades relacionadas à documentação apresentada ${ }^{211}$.

\footnotetext{
${ }^{209}$ Art. $8^{\circ}, \S 3^{\text {o }}$ da Lei $n^{\text {o }} .9 .782$ de 26 de janeiro de 1999.

${ }^{210}$ Art. $8^{\mathrm{o}}, \S 4^{\mathrm{o}}$ da Lei $\mathrm{n}^{\mathrm{o}} .9 .782$ de 26 de janeiro de 1999.

${ }^{211}$ Em dezembro de 2010, a ANVISA suspendeu, em todo o país, a venda do produto "Divine Shen". Com registro obtido junto ao órgão como suplemento alimentar emagrecedor, à base de fibra de laranja, descobriu-se, após denuncia de consumidores, que, na realidade, o produto continha sibutramina,
} 


\subsubsection{O INMETRO}

O Instituo Nacional de Metrologia, Normalização e Qualidade Industrial é uma autarquia federal, órgão colegiado subordinado ao Ministério do Desenvolvimento, Indústria e Comércio Exterior, criado pela Lei nº 5.966 de 11 de dezembro de 1973 com o objetivo de substituir e ampliar a atuação do Instituto Nacional de Pesos e Medidas (INPM), com competência para expedir atos normativos e regulamentos técnicos, nos campos da Metrologia e da Avaliação da Conformidade de produtos, de processos e de serviços.

O objetivo do Instituto é incrementar a qualidade de produtos e serviços oferecidos pelas empresas nacionais por meio da promoção da confiança da sociedade "nas medições e nos produtos, através da metrologia e da avaliação da conformidade, promovendo a harmonização das relações de consumo, a inovação e a competitividade do País" ${ }^{212}$.

O INMETRO, dentre outras funções executa as políticas nacionais de metrologia e da qualidade; verifica a observância das normas técnicas e legais, no que se refere às unidades de medida, métodos de medição, medidas materializadas, instrumentos de medição e produtos pré-medidos; fomenta a utilização da técnica de gestão da qualidade nas empresas brasileiras; planeja e executar as atividades de acreditação de laboratórios de calibração e de ensaios, de provedores de ensaios de proficiência, de organismos de certificação, de inspeção, de treinamento e de outros, necessários ao desenvolvimento da infra-estrutura de serviços tecnológicos no País; e Desenvolve programas de avaliação da conformidade, nas áreas de produtos, processos, serviços e pessoal, compulsórios ou voluntários, que envolvem a aprovação de regulamentos ${ }^{213}$.

substância de uso controlado no Brasil e proibido na Europa. A ANVISA alegou que a licença para a comercialização era baseada nos dados fornecidos pelo fabricante. O informe técnico $\mathrm{n}^{\circ}$. 44 de 22 de dezembro de 2010, que suspende sua venda, suspende, ainda, a da erva "Caralluma Fimbriata", também vendida para a perda de peso. ANVISA. Informe Técnico n. 44, de 22 de dezembro de 2010. Esclarecimentos das medidas adotadas sobre os produtos de marca "Divine Shen" e o insumo "Caralluma fimbriata". Disponível em: <http://portal.anvisa.gov.br/wps/wcm/connect/368c04004526602ba8d6f82475bf1 155/Informe+T\%C3\%A9 cnico+Divine+Shen+e+Caralluma+fimbriata.pdf?MOD=AJPERES. Acesso em: 27 dez. 2010.

${ }^{212}$ Informação referente à missão do INMETRO obtida no site do Instituto. INMETRO. O que é o Inmetro. Disponível em: <http://www.inmetro.gov.br/inmetro/oque.asp.>. Acesso em: 27 dez. 2010.

${ }^{213}$ Id. Ibid. 
A Lei $\mathrm{n}^{\circ} .9 .933$ de 20 de dezembro de 1999 dispõe sobre a competência do Inmetro $^{214}$ e determina que todos os bens comercializados no Brasil, insumos, produtos finais e serviços, sujeitos a regulamentação técnica, devem estar em conformidade com os regulamentos técnicos pertinentes em vigor no que se refere a aspectos relacionados a segurança, prevenção de práticas enganosas de comércio, proteção da vida e saúde humana, animal e vegetal, e ao meio ambiente.

Conforme o artigo $5^{\circ}$ da Lei $\mathrm{n}^{\circ}$. 9.933/90 devem cumprir os deveres nela estabelecidos, assim como nos atos normativos e regulamentos técnicos e administrativos expedidos pelo Conmetro e pelo Inmetro, as pessoas naturais e as pessoas jurídicas, nacionais e estrangeiras, que atuem no mercado fabricando, importando, processando montando, acondicionando ou comercializando bens, mercadorias e produtos e prestando serviços.

O Instituto é competente para isolada ou cumulativamente advertir, multar, interditar, apreender e inutilizar em caso de infração às suas normas legais por pessoa natural ou a pessoa jurídica, nacional ou estrangeira, que, no exercício das atividades acima referidas, deixar de cumprir os deveres jurídicos.

O Inmetro certifica uma série de produtos que, no Brasil, podem ser de certificação compulsória ou voluntaria. Em dezembro de 2010 o Instituto apresentava uma relação atualizada de produtos com certificação compulsória contendo oitenta e cinco itens dos quais detém ou não a competência para a certificação. São eles:

\begin{tabular}{|c|c|}
\hline PRODUTO & $\begin{array}{c}\text { ÓRGÃO } \\
\text { REGULAMENTADOR }\end{array}$ \\
\hline $\begin{array}{l}\text { - Mangueiras de PVC plastificados, para instalações domésticas } \\
\text { de GLP; Reguladores de baixa pressão para gases liquefeitos } \\
\text { de petróleo (GLP) com capacidade até } 4 \mathrm{~kg} / \mathrm{h} \text {. }\end{array}$ & $\begin{array}{c}\text { Agência Nacional do Petróleo - } \\
\text { ANP }\end{array}$ \\
\hline $\begin{array}{l}\text { - Contentores intermediários para granéis (IBC) utilizado nop } \\
\text { transporte de produtos perigosos; Embalagens grandes } \\
\text { utilizadas no transporte de produtos perigosos; Embalagens } \\
\text { Recondicionadas Utilizadas no Transporte Terrestre de } \\
\text { Produtos Perigosos; Embalagens Refabricadas Utilizadas no } \\
\text { Transporte Terrestre de Produtos Perigosos; Tanques portáteis } \\
\text { utilizados no transporte terrestre de produtos perigosos. }\end{array}$ & ANTT - \\
\hline - Preservativos masculinos. & Anvisa \\
\hline
\end{tabular}

\footnotetext{
${ }^{214}$ A competência do Inmetro é residual, devendo, portanto, tratar de produtos que não sejam de competência de outros órgãos e de outras entidades da Administração Pública Federal.
} 


\begin{tabular}{|c|c|}
\hline $\begin{array}{l}\text { - PROVEM - Programa Nacional de Certificação de } \\
\text { Conformidade de Veículos Automotores - Emissões; Tanque } \\
\text { de armazenamento subterrâneo de combustível em posto } \\
\text { revendedor; Tanques Aéreos de Armazenamento de Derivados } \\
\text { de Petróleo e outros Combustíveis; Tubulação não metálica } \\
\text { subterrânea para combustível automotivo. }\end{array}$ & Conama \\
\hline $\begin{array}{l}\text { - Pneus Novos de Motocicleta, Motoneta e Ciclomotor, } \\
\text { Automóvel de Passageiros, inclusive os de uso misto, e } \\
\text { rebocados, Veículos Comerciais, Comerciais Leves e } \\
\text { Rebocados; }\end{array}$ & Conmetro \\
\hline $\begin{array}{l}\text { - Carroçaria de ônibus urbano - Padronização; Cilindros de alta } \\
\text { pressão para armazenamento de gás natural veicular como } \\
\text { combustível, a bordo de veículos automotores; Componentes } \\
\text { dos sistemas de descarga e de abastecimento de combustíveis; } \\
\text { Vidro de segurança laminado para pára-brisa de veículos } \\
\text { rodoviários automotor; Vidro de segurança temperados para } \\
\text { veículos rodoviários automotor. }\end{array}$ & Contran \\
\hline $\begin{array}{l}\text { - Construção de Embarcações acessíveis para transporte } \\
\text { coletivo de passageiros; Fabricação de Veículos Acessíveis de } \\
\text { Características Urbanas para Transporte Coletivo de } \\
\text { Passageiros; Fabricação de Veículos Acessíveis de } \\
\text { Características Rodoviárias para Transporte Coletivo de } \\
\text { Passageiros. }\end{array}$ & $\begin{array}{c}\text { Corde - Coordenadoria Nacional } \\
\text { para a Integração da Pessoa } \\
\text { Portadora de Deficiência }\end{array}$ \\
\hline $\begin{array}{l}\text { - Adaptadores de plugues e tomadas; Aparelho para melhoria da } \\
\text { qualidade da água para consumo humano; Aros de bicicleta } \\
\text { de uso adulto; Artigos escolares; Barras e fios de aço } \\
\text { destinados a armaduras para estruturas de concreto armado; } \\
\text { Bebedouros; Cabo de potência com isolação sólida extrudada, } \\
\text { de PVC, para tensões de } 0,6 / 1,0 \mathrm{kV} \text {; Cabos de aço de uso } \\
\text { geral; Cabos e cordões flexíveis isolados com PVC, para } \\
\text { aplicações específicas em cordões conectores de aparelhos } \\
\text { eletrodomésticos em tensões até 500V; Cabos e cordões } \\
\text { flexíveis para tensão até } 750 \text { v, com isolação / cobertura } \\
\text { extrudada de cloreto de polivinila (PVC) ; Cabos flexíveis } \\
\text { isolados com borracha EPR, para aplicações específicas em } \\
\text { cordões conectores de aparelhos eletrodomésticos em tensões } \\
\text { até } 500 \text { V; Cadeira plástica monobloco; Câmaras de Ar para } \\
\text { Pneus de Bicicletas de Uso Adulto; Câmaras de Ar para Pneus } \\
\text { de Bicicletas de Uso Adulto; Capacetes para condutores e } \\
\text { passageiros de motocicletas e similares; Componentes do } \\
\text { sistema para gás natural veicular; Condutores isolados com } \\
\text { policloreto de vinila (PVC), para tensões nominais de } 450 / 750 \\
\text { V, sem cobertura, para instalações fixas; Conexões de ferro } \\
\text { fundido maleável para a condução de fluidos; Conjunto de }\end{array}$ & Inmetro \\
\hline
\end{tabular}


Direção (Guidão e Suporte de Guidão) de Bicicleta de Uso Adulto; Conjuntos de freio de Bicicleta de Uso Adulto; Conjunto Quadro e Garfo de Bicicleta de Uso Adulto; Copos plásticos descartáveis; Cordoalhas de Bicicleta de Uso Adulto; Cordões flexíveis com isolação extrudada de polietileno de clorossulfonado (CSP), para tensões até 300 V; Disjuntores; Dispositivo de fixação de contêiner; Dispositivo de retenção para crianças; Equipamentos Elétricos para Atmosferas Explosivas, nas Condições de Gases e Vapores Inflamáveis e Poeiras Combustíveis; Estabilizadores de tensão monofásicos, com saída de tensão alternada , com tensão nominal de até 250 $\mathrm{V}$ em potências de até $3 \mathrm{kVA} / 3 \mathrm{KW}$; Fabricação ou importação de extintores de incêndio; Filtros adicionais para óleo diesel, tipo prensa; Fósforos de segurança; Fusíveis tipo rolha e tipo cartucho;

- Interruptores para instalações elétricas fixas domésticas e análogas;

- Niples de Bicicleta de Uso Adulto; Pino-Rei para veículo rodoviário destinado ao transporte de cargas e produtos perigosos;

- Plugues e tomadas para uso doméstico e análogo; Panelas de pressão; Pedal e Pedivela de Bicicleta de Uso Adulto; Pneus de bicicleta de uso adulto; Pneus novos para motocicletas, motonetas e ciclomotores; Quinta-Roda Utilizada em Veículo Rodoviário Destinado ao Transporte de Cargas e de Produtos Perigosos; Raios de Bicicleta de Uso Adulto; Reatores eletrônicos alimentados em corrente alternada para lâmpadas fluorescentes tubulares retilineas, circulares e compactas; Reatores para lâmpadas fluorescentes tubulares; Recipientes Transportáveis para Gás Liquefeito de Petroleo - GLP; Rodas Automotivas; Segurança de Aparelhos Eletrodomésticos e Similares; Segurança de bicicletas de uso infantil; Segurança em brinquedos; Serviço adaptação de dispositivo de fixação de contêiner; Tubos de aço-carbono para usos comuns na condução de fluidos.

- Equipamentos eletromédicos. Ministério da Saúde

- Embalagem para transporte terrestre de fósforo de segurança; Embalagens utilizadas no transporte terrestre de produtos perigosos.

- Capacete de Segurança para Uso na Industria; Equipamentos de proteção Individual (EPI) - Luvas Isolantes de Borracha; Equipamentos de proteção Individual (EPI) - Peça Semifacial MTE (Ministério do Trabalho e Filtrante para Partículas.

Ministério dos Transportes

- Luvas Cirúrgicas e de Procedimento Não Cirúrgico de Anvisa e MTETEM 


\begin{tabular}{|c|c|}
\hline $\begin{array}{l}\text { Borracha Natural, Borracha Sintética e de Misturas de } \\
\text { Borrachas Sintéticas. }\end{array}$ & \\
\hline $\begin{array}{l}\text { - Chupetas; Embalagens destinada ao envasilhamento de álcool; } \\
\text { Mamadeiras e bicos de mamadeira. }\end{array}$ & Inmetro e Anvisa \\
\hline $\begin{array}{l}\text { - Cilindros de aço sem costura, destinados ao armazenamento } \\
\text { de gás metano veicular; Eixo veicular auxiliar; Veículo porta- } \\
\text { contêiner. }\end{array}$ & Inmetro e Cotran \\
\hline
\end{tabular}

Com o objetivo de estabelecer uma estrutura de certificação de conformidade ${ }^{215} \mathrm{e}$ tutelar o consumidor, foi instituído pelo Conselho Nacional de Metrologia, Normalização e Qualidade Industrial (Conmetro), por meio da pela Resolução 08/92 $2^{216}$, o Sistema Brasileito de Certificação (SBC), reconhecido em todo o Brasil e competente para editar suas próprias regras, bem como, seus procedimentos de gestão.

Com a certificação de conformidade se busca o incremento da qualidade de produtos, processos e serviços e, consequentemente, e uma melhor posição no mercado ${ }^{217}$, pois, sugere ao consumidor que há o atendimento de padrões desejáveis de qualidade, seja no que se refere a padrões.

Como afirmado anteriormente, a certificação pode ser voluntária ou compulsória. Os produtos de certificação compulsória, acima relacionados, devem, necessária e obrigatoriamente, ser submetidos à análise prévia do órgão competente, não podendo ser disponibilizado ao mercado consumidor sem o devido certificado. Os produtos que de qualquer forma se relacionem à saúde, à segurança e ao meio ambiente são, em geral, de certificação compulsória. A certificação voluntária, por sua vez, é de iniciativa da empresa produtora de produtos ou prestadora de serviços e visa a garantia de conformidade de processos produtos e serviços às normas elaboradas pelas entidades reconhecidas pelo Sinmetro.

\footnotetext{
215 Trata-se de documento capaz de certificar qualquer material, componente, equipamento, interface, protocolo, procedimento, função, método e atividade de organismos ou pessoas, emitido por um organismo de certificação, credenciado pelo Inmetro atestando a qualidade do sistema, processo, produto ou serviço. Para a verificação da qualidade, tem-se como parâmetro normas expedidas por entidades reconhecidas pelo Sinmetro ou baseadas em regulamentos técnicos emitidos por órgãos regulamentadores oficiais.

${ }^{216}$ Esta Resolução foi revista pela Resolução 02/97.

217 A certificação é importante para a circulação interna de mercadorias, bem como, para sua importação e exportação. Faz-se necessária a compatibilidade entre os sistemas de certificação entre os países que se relacionam economicamente, trocando bens e serviços.
} 


\subsubsection{Liberação de produto ao mercado de consumo no Brasil}

Para ilustrar o que foi dito até aqui e para que se entenda o processo de autorização para que um produto seja liberado ao mercado de consumo nacional, bem como, sua fiscalização, será utilizado, como exemplo, o caso dos medicamentos, cuja atribuição de conceder registro e de fiscalizar cabe à ANVISA.

A ANVISA é o órgão responsável não apenas pelo registro dos medicamentos comercializado no Brasil, mas, também, pela autorização de funcionamento de empresas da cadeia farmacêutica, inclusive de seus laboratórios. É ela quem analisa os pedidos de patentes referentes a esse tipo de produto juntamente com o INPI, Instituto Nacional da Propriedade Industrial. Além disso, é responsável pela inspeção e controle de qualidade dos medicamentos, função que se estende à pós-comercialização.

Quando alguém quer comercializar no mercado de brasileiro um medicamento de uso controlado, deve seguir o seguinte um trâmite estabelecido pelo Ministério da Saúde por intermédio da Agência Nacional de Vigilância Sanitária.

A Portaria $\mathrm{n}^{\text {o. }} 344$ de 12 de maio de $1998^{218}$, aprova, segundo sua ementa, o Regulamento Técnico sobre substâncias e medicamentos sujeitos a controle especial.

Para manipular ou fabricar as substâncias elencadas pela Portaria SVS/MS nº 344, as empresas devem atender as Boas Práticas de Manipulação (BPM) e Boas Práticas de Fabricação (BPF). Segundo o artigo $2^{\circ}$ da sobredita Portaria, para extrair, produzir, fabricar, beneficiar, distribuir, transportar, preparar, manipular, fracionar, importar, exportar, transformar, embalar, reembalar, para qualquer fim, as substâncias constantes das listas $^{219}$ deste Regulamento Técnico e de suas atualizações, ou os medicamentos que as

\footnotetext{
${ }^{218}$ Atualizada pela Resolução-RDC 249, de 05/09/2002, publicada no D.O.U. de 06/09/2002. Revogada parcialmente pela Resolução-RDC n 201, de 18/17/2002 e alterada pela Resolução-RDC n 249, de 05/09/2002.

${ }^{219}$ Estas listas tratam de substâncias: a) sujeitas à notificação de Receita "A": entorpecentes, (A1); entorpecentes de uso permitido somente em concentrações especiais, (A2); psicotrópicas, (A3); b) sujeitas à notificação de Receita “B”: psicotrópicas, (B1); substâncias psicotrópicas anorexígenas, (Lista B2); c) sujeitas à Receita de Controle Especial em duas vias: outras substâncias sujeitas a controle especial, (C1) dentre as quais figura a sibutramina; substâncias anabolizantes (C5); d) sujeitas à notificação de Receita Especial: substâncias retinoicas, (C2); substâncias imunossupressoras, (C3), dentre as quais a ftalimidoglutarimida (talidomida); e) sujeitas a Receituário do Programa da DST/AIDS ou Sujeitas a Receita de Controle Especial em duas vias: substâncias antiretrovirais (C4); substâncias anabolizantes, (Lista C5); f) sujeitas a Receita Médica sem Retenção: precursoras de entorpecentes e/ou psicotrópicos (D1); g) sujeitas a controle do Ministério da Justiça: insumos químicos utilizados como precursores para fabricação e síntese de entorpecentes e/ou psicotrópicos (D2); h) plantas que podem originar substâncias entorpecentes ou psicotrópicas $(\mathrm{E})$; i) de uso proscrito no Brasil $(\mathrm{F})$ : entorpecentes $(\mathrm{F} 1)$; psicotrópicas $(\mathrm{F} 2)$ e outras substâncias (F3).
} 
contenham, é obrigatória a obtenção de Autorização Especial concedida pela Secretaria de Vigilância Sanitária do Ministério da Saúde.

Deve-se, inicialmente, protocolizar uma petição de Autorização Especial pelos responsáveis dos estabelecimentos da empresa junto à Autoridade Sanitária local que inspecionará o estabelecimento vinculado à referida empresa e emitirá parecer, encaminhando relatório à Secretaria de Vigilância Sanitária do Ministério da Saúde. Deferida a petição, a Secretaria envia o Certificado de Autorização Especial para a empresa e comunicará a decisão à Autoridade Sanitária local. Somente após a publicação no Diário Oficial da União é que as atividades podem ser iniciadas ${ }^{220}$.

A petição de concessão de Autorização Especial deve ser instruída dentre outros documentos e informações com a prova de prova de habilitação legal, junto ao respectivo Conselho Regional, do farmacêutico ou químico, responsável técnico; com a relação das substâncias ou medicamentos objeto da atividade a ser autorizada com indicação dos nomes (DCB ou químico) a serem utilizados e da estimativa das quantidades a serem inicialmente trabalhadas; com a cópia do Manual ou Instruções concernentes às Boas Práticas de Fabricação ou de Manipulação adotado pela empresa ${ }^{221}$. Ou seja, cabe aos responsáveis pela empresa a contratação de um responsável técnico legalmente habilitado que elenque as substâncias que efetivamente componham o medicamento nas quantidades declaradas e que siga o Manual de Boas Práticas de Fabricação ou de Manipulação adequado às recomendações do Ministério da Saúde. A Autorização Especial pode ser suspensa ou cancelada se ficar comprovada irregularidade que configure infração sanitária praticada pelo estabelecimento ${ }^{222}$.

Em caso de importação de medicamento, a empresa necessita de autorização prévia da ANVISA ${ }^{223}$. Para importar as substâncias entorpecentes (A1 e A2), psicotrópicas (A3, B1 e B2), imunossupressoras (C3) e precursoras (D1) da qual depende de Autorização de Importação emitida pena Secretaria de Vigilância Sanitária do Ministério da Saúde ${ }^{224}$, a empresa importadora é obrigada a solicitar a fixação da chamada Cota Anual de Importação ${ }^{225}$. A empresa deve, ainda, comprovar, no momento da entrada da substância no país, o cumprimento das Boas Práticas de Fabricação pelas respectivas unidades fabris

\footnotetext{
${ }^{220}$ Artigo $2^{\circ}$ da Portaria 344/98 da Anvisa.

${ }^{221}$ Artigo $3^{\circ}$ da Portaria SVS/MS no 344.

${ }^{222}$ Artigo 10 da Portaria SVS/MS no 344.

${ }^{223}$ Artigo 13 da Portaria SVS/MS no 344.

${ }^{224}$ Artigo 14 da Portaria SVS/MS no 344.

${ }^{225}$ Artigo 11 da Portaria SVS/MS no 344.
} 
de origem, mediante a apresentação do competente Certificado, emitido a menos de dois anos, pela Autoridade Sanitária do país de procedência ${ }^{226}$.

A indústria farmoquímica, os laboratórios farmacêuticos, as distribuidoras, as drogarias e as farmácias devem escriturar e manter no estabelecimento para efeito de fiscalização e controle, um Livro de Registro Específico ${ }^{227}$ para que sejam efetuadas anotações, em ordem cronológica, de estoque, entradas (por aquisição ou produção), saídas (por vendas, processamento, beneficiamento, uso) e perdas das substâncias ${ }^{228}$.

A Secretaria de Vigilância Sanitária do Ministério da Saúde deve padronizar bulas, rótulos e embalagens dos medicamentos constantes da Portaria SVS/MS nº $344^{229}$.

Compete aos Estados, aos Municípios e ao Distrito Federal a fiscalização e o controle da produção e da comercialização, bem como, fazer cumprir as determinações legais referentes aos referidos produtos. Cabe, além dos entes federativos, às Autoridades Sanitárias do Ministério da Saúde, inspecionar as empresas para verificar se estão sendo cumpridas as determinações da ANVISA.

Em caso de descumprimento das exigências do Regulamento ocorrerá infração sanitária, sem prejuízo das sanções de natureza civil e penal previstas.

O Departamento de Polícia de Proteção à Cidadania do Estado de São Paulo (DPPC-SP) publicou em 2009 um manual de legislação e prática versando, dentre outros assuntos, sobre a "Divisão de Investigações sobre Infrações contra a Saúde Pública" 230. Este documento traz uma relação das características e condições em que são encontrados os medicamentos colocados no mercado de consumo pelos falsificadores. São elas: produtos que não produzem qualquer efeito contra a patologia que dizem tratar; remédios

\footnotetext{
${ }^{226}$ Artigo 103 da Portaria SVS/MS no 344.

${ }^{227}$ Artigo 62 da Portaria SVS/MS n 344.

${ }^{228}$ Artigo 65 da Portaria SVS/MS no 344.

${ }^{229}$ Artigo 77 da Portaria SVS/MS no 344 . Em alguns casos, há a especificação detalhada dos itens que devem constar da embalagem. Um exemplo é o artigo 80 determina que as embalagens de medicamentos a base de substâncias A1e A2 (entorpecentes) e A3 (psicotrópicos), deverão ter uma faixa horizontal preta abrangendo todos os lados, na altura do terço médio e com largura não inferior a um terço da largura do maior lado da face maior, contendo os dizeres: "Venda sob Prescrição Médica" - "Atenção: Pode Causar Dependência Física ou Psíquica". Outro, é o artigo 84 que determina que os medicamentos de uso sistêmico, a base de substâncias C2 (retinoicas) deste devem ter uma faixa horizontal de cor vermelha abrangendo todos os seus lados, na altura do terço médio e com largura não inferior a um terço da largura do maior lado da face maior, contendo os dizeres "Venda Sob Prescrição Médica" - "Atenção: Risco para Mulheres Grávidas, Causa Graves Defeitos na Face, nas Orelhas, no Coração e no Sistema Nervoso do Feto".

${ }^{230}$ DEPARTAMENTO DE POLÍCIA DE PROTEÇÃO À Cidadania (DPPC). Legislação e prática. São Paulo, $2009 . \quad$ Disponível em: <http://www.portalapas.org.br/imagens/destaques_home/091210/CARTILHA_DPPC.pdf>. Acesso em: 29 dez. 2010.
} 
com a dosagem de substância ativa menor que a informada pela embalagem ou bula; medicamentos feitos a partir de água e farinha; remédios que possuem a substância ativa na quantidade correta, mas que são fabricados em laboratórios clandestinos sem nenhuma higiene e qualidade; e "amostra grátis" com prazo de validade vencido, substituindo-se apenas a embalagem (muitas vezes com o número do lote, a data de fabricação e o prazo de validade adulterados).

\subsection{Excessos e insuficiências da tutela penal do consumidor e das relações de consumo no que se refere à produção e comercialização de produtos}

No Brasil, a tutela penal do consumidor e das relações de consumo, notadamente, naquilo que se refere à fabricação e colocação de produtos defeituosos ou inadequados no mercado de consumo é feita, principalmente, pelos seguintes diplomas normativos: Lei $\mathrm{n}^{\circ}$. 8.078 de 11 de setembro de 1990; Código Penal e Lei nº 8.137 de 27 de dezembro de 1990.

A Lei $\mathrm{n}^{\circ}$. 8.078/90, o Código de Defesa do Consumidor, tutela penalmente o consumidor em seu Título II criminalizando condutas que coloquem em risco ou lesionem seus bens jurídicos.

$\mathrm{O}$ artigo 61 inaugura a Parte Penal do CDC, declarando que as condutas ali tipificadas não necessariamente revogam outras figuras típicas constantes de outros diplomas normativos que visem a tutela do consumidor ${ }^{231}$.

No artigo 63 é estabelecida a pena de detenção de seis meses a dois anos e multa para a omissão, em embalagens, invólucros, recipientes ou publicidade, de dizeres ou sinais ostensivos e de alerta sobre a nocividade ou periculosidade de produtos, conduta para a qual prevê-se a modalidade culposa $\left(\S 2^{\circ}\right)$, com pena de detenção de um a seis meses e multa ${ }^{232}$.

\footnotetext{
${ }^{231}$ Art. 61. Constituem crimes contra as relações de consumo previstas neste código, sem prejuízo do disposto no Código Penal e leis especiais, as condutas tipificadas nos artigos seguintes.

${ }^{232}$ Art. 63. Omitir dizeres ou sinais ostensivos sobre a nocividade ou periculosidade de produtos, nas embalagens, nos invólucros, recipientes ou publicidade: Pena - Detenção de seis meses a dois anos e multa. $\S 1^{\circ}$ - Incorrerá nas mesmas penas quem deixar de alertar, mediante recomendações escritas ostensivas, sobre a periculosidade do serviço a ser prestado. $\S 2^{\circ}$ - Se o crime é culposo: Pena: Detenção de um a seis meses ou multa.
} 
No caput do artigo 64 tipifica-se a conduta de omissão de comunicação à autoridade competente e aos consumidores a nocividade ou periculosidade de produtos cujo conhecimento tenha sido posterior à sua colocação no mercado, prevendo, para tal, a pena de detenção de seis meses a dois anos e multa ${ }^{233}$. O parágrafo único, por sua vez, criminaliza a omissão da retirada de os produtos nocivos ou perigosos do mercado que tenha sido determinada por autoridade competente ${ }^{234}$.

O artigo 66 tipifica a fraude em oferta ao consumidor, criminalizando a afirmação falsa ou enganosa, bem como, a omissão de informação relevante sobre a natureza, característica, qualidade, quantidade, segurança, desempenho, durabilidade, preço ou garantia de produtos ou serviços, estabelecendo a pena de detenção de três meses a um ano e multa e admitindo a modalidade culposa $\left(\S 2^{\circ}\right)$, com pena reduzida de um a seis meses e multa. $\mathrm{O} \S 1^{\circ}$ estende a responsabilidade ao patrocinador da oferta ${ }^{235}$.

De acordo com o art. 75 do CDC

Quem, de qualquer forma, concorrer para os crimes referidos neste código, incide as penas a esses cominadas na medida de sua culpabilidade, bem como o diretor, administrador ou gerente da pessoa jurídica que promover, permitir ou por qualquer modo aprovar o fornecimento, oferta, exposição à venda ou manutenção em depósito de produtos ou a oferta e prestação de serviços nas condições por ele proibidas.

São consideradas circunstâncias agravantes dos crimes do Código de Defesa do Consumidor, conforme o art. 76: I - serem cometidos em época de grave crise econômica ou por ocasião de calamidade; II - ocasionarem grave dano individual ou coletivo; III dissimular-se a natureza ilícita do procedimento; IV - quando cometidos: a) por servidor público, ou por pessoa cuja condição econômico-social seja manifestamente superior à da vítima; b) em detrimento de operário ou rurícola; de menor de dezoito ou maior de sessenta anos ou de pessoas portadoras de deficiência mental interditadas ou não; V - serem

\footnotetext{
${ }^{233}$ Art. 64. Deixar de comunicar à autoridade competente e aos consumidores a nocividade ou periculosidade de produtos cujo conhecimento seja posterior à sua colocação no mercado: Pena - Detenção de seis meses a dois anos e multa.

${ }^{234}$ Art. 64. Parágrafo único. Incorrerá nas mesmas penas quem deixar de retirar do mercado, imediatamente quando determinado pela autoridade competente, os produtos nocivos ou perigosos, na forma deste artigo.

${ }^{235}$ Art. 66. Fazer afirmação falsa ou enganosa, ou omitir informação relevante sobre a natureza, característica, qualidade, quantidade, segurança, desempenho, durabilidade, preço ou garantia de produtos ou serviços: Pena - Detenção de três meses a um ano e multa. $\S 1^{\circ}$ Incorrerá nas mesmas penas quem patrocinar a oferta. $\S 2^{\circ}$ Se o crime é culposo; Pena Detenção de um a seis meses ou multa.
} 
praticados em operações que envolvam alimentos, medicamentos ou quaisquer outros produtos ou serviços essenciais .

As penas previstas no CDC são, cumulativa ou alternadamente, as privativas de liberdade, de multa, alternadamente, a interdição temporária de direitos; a publicação em órgãos de comunicação de grande circulação ou audiência, às expensas do condenado, de notícia sobre os fatos e a condenação; e a prestação de serviços à comunidade.

Embora tipifique a omissão da advertência ou do alerta ao consumidor a respeito periculosidade ou nocividade do produto e também a sua retirada do mercado de consumo quando estas características forem posteriormente percebidas, o CDC deixa de criminalizar a conduta de produção e comercialização de produtos que possam colocar em risco ou lesar a saúde, vida ou a integridade física do consumidor, sendo tais bens jurídicos, neste particular, deixados à tutela de outros ramos do ordenamento jurídico, menos duros que o Direito Penal.

O artigo 62 que supriria esta sentida lacuna da referida lei, recebeu veto presidencial sob a alegação de afronta ao Princípio da Legalidade, mais especificamente, em relação à taxatividade da norma. A saber:

Colocar no mercado, fornecer ou expor para fornecimento produtos ou serviços impróprios.

Pena - Detenção de seis meses a dois anos e multa.

$\S 1^{\circ}$ - Se o crime é culposo:

Pena - Detenção de três meses a um ano ou multa.

$\S 2^{\circ}$ - As penas deste artigo são aplicáveis sem prejuízo das correspondentes à lesão corporal e à morte.

A razão dada para que se desse o veto foi, textualmente, a seguinte:

Em se tratando de norma penal, é necessário que a descrição da conduta vedada seja precisa e determinada. Assim, o dispositivo afronta a garantia estabelecida no art. $5^{\circ}$, XXXIX, da Constituição.

O veto encontra eco na doutrina especializada e, neste sentido, Paulo José da Costa Júnior, assevera:

"De fato, um dos corolários do princípio da legalidade é o princípio da taxatividade do tipo penal. De acordo com mencionado princípio, o tipo penal deverá ser claro, determinado, descrevendo com precisão a conduta incriminada. Veda-se, assim, a criação de tipos penais abertos, vagos e 
indeterminados, que gerem insegurança jurídica. Com efeito, como fazer para estabelecer que o produto ou serviço são impróprios?"236

A resposta a esta pergunta é dada, curiosamente, pelo próprio Código de Defesa do Consumidor, em seu artigo $18 \S 6^{\circ}$ que elenca como impróprios ao uso e consumo: I - os produtos cujos prazos de validade estejam vencidos; II - os produtos deteriorados, alterados, adulterados, avariados, falsificados, corrompidos, fraudados, nocivos à vida ou à saúde, perigosos ou, ainda, aqueles em desacordo com as normas regulamentares de fabricação, distribuição ou apresentação; III - os produtos que, por qualquer motivo, se revelem inadequados ao fim a que se destinam.

Trata-se, portanto, o dispositivo em análise, de norma penal em branco em sentido lato, ou seja, é espécie de norma penal que reclama a complementação por outra norma, no caso, oriunda do mesmo diploma legal. Não há qualquer problema em relação à taxatividade e, consequentemente, à legalidade do dispositivo. Tanto é assim que, pouco mais de três meses após a edição do Código de Defesa do Consumidor, em 11 de setembro de 1990, foi editada, em 27 de dezembro, a Lei $n^{\circ}$. 8.137, contendo norma semelhante àquela entendida, anteriormente, como inadequada por conta de uma suposta vaguidade em seu texto. $\mathrm{O}$ art. $7^{\circ}$, IX, determina como crime contra as relações de consumo:

$7^{\circ} \mathrm{IX}$ - vender, ter em depósito para vender ou expor à venda ou, de qualquer forma, entregar matéria-prima ou mercadoria, em condições impróprias ao consumo;

Pena - detenção, de 2 (dois) a 5 (cinco) anos, ou multa.

Parágrafo único. Nas hipóteses dos incisos II, III e IX pune-se a modalidade culposa, reduzindo-se a pena e a detenção de 1/3 (um terço) ou a de multa à quinta parte.

A integração deste dispositivo é feita pelo art. $18 \S 6^{\circ}$ do $\mathrm{CDC}$, sem qualquer problema, fazendo parecer que, a opção pelo veto do art. 62 nada teve a ver com imprecisão técnica da norma penal, mas com uma opção político-criminal, meses depois revista.

Se por um lado faltam normas ao Código de Defesa do Consumidor, por outro sobram. Diversos tipos penais constantes da referida lei são excessivos e desnecessários. Em seu art. 74, por exemplo, criminaliza a conduta daquele que deixar de entregar ao

\footnotetext{
${ }^{236}$ COSTA JUNIOR, Paulo José da; COSTA, Fernando José da. Crimes contra o consumidor. 2. ed. São
} Paulo: Atlas, 2008. p. 4. 
consumidor o termo de garantia adequadamente preenchido e com especificação clara de seu conteúdo. Não há qualquer razão para que essa conduta seja tipificada como crime. Embora possa se supor que há a tentativa de tutelar-se a propriedade do consumidor, fica clara a suficiência do Direito Civil para solucionar qualquer conflito que daí possa surgir sendo absolutamente inadequado o uso do Direito Penal.

O Código Penal brasileiro, por sua vez, tutela o consumidor de forma reflexa por intermédio da tipificação de condutas que variam do estelionato e fraudes até os crimes contra a saúde pública.

O artigo 171 do CP determina a pena de reclusão de um a cinco anos e multa para o crime de estelionato que tipifica como a obtenção para si ou para outrem, vantagem ilícita, em prejuízo alheio, induzindo ou mantendo alguém em erro, mediante artifício, ardil, ou qualquer outro meio fraudulento

A fraude no comércio é o ato, previsto no artigo 175 de enganar, no exercício de atividade comercial, o adquirente ou consumidor vendendo, como verdadeira ou perfeita, mercadoria falsificada ou deteriorada ou entregando uma mercadoria por outra. A pena para este delito é de detenção de seis meses a dois anos ou multa. De acordo com o $\S 1^{\circ}$, tratam-se de condutas muito mais graves a alteração em obra que da qualidade ou o peso de metal ou a substituição de pedra verdadeira por falsa ou por outra de menor valor; a venda de pedra falsa por verdadeira; bem como a venda, como precioso, de metal de ou outra qualidade. Deste modo, comina para tais crimes de fraude a pena de reclusão de um a cinco anos e multa.

Na seara dos crimes contra a saúde pública encontram-se tipificadas diversas condutas.

O artigo 272 comina a pena de quatro a oito anos de reclusão e multa para quem corromper, adulterar, falsificar ou alterar substância, produto alimentício destinado a consumo, bem como, bebidas, com ou sem teor alcoólico $\left(\S 1^{\circ}\right)$, tornando-as nocivas à saúde ou reduzindo-lhe o valor nutritivo, pena que estende àqueles que fabricam, vendem, expõem à venda, importam, têm em depósito para vender ou, de qualquer forma, distribuem ou entregam a consumo a substância alimentícia ou o produto falsificado, corrompido ou adulterado $\left(\S 1^{\circ}-\mathrm{A}\right)$. $\mathrm{O} \S 2^{\circ}$ do artigo em tela prevê a modalidade culposa para o delito ao qual comina a pena de detenção de um a dois anos e multa. 
No que diz respeito aos produtos destinados a fins terapêuticos ou medicinais, o artigo 273 criminaliza sua falsificação, corrupção, adulteração ou alteração, (caput), e também, a importação, venda, exposição à venda, o depósito ou qualquer forma de distribuição ou entrega ao consumo dos referidos produtos falsificados, corrompidos, adulterados ou alterados $\left(\S 1^{\circ}\right)$. Para tais condutas estabelece a pena de reclusão de dez a quinze anos e multa para a modalidade dolosa e de detenção de um a três anos e multa para a modalidade culposa $\left(\S 2^{\circ}\right)$.

$\mathrm{O} \S 1^{\circ}$-A amplia o alcance da norma incluindo entre os produtos a que se refere o artigo 273, os medicamentos, as matérias-primas, os insumos farmacêuticos, os cosméticos, os saneantes e os de uso em diagnóstico.

Estendendo ainda mais a abrangência do tipo, o $\S 1^{\circ}$-B determina que, além de falsificados, corrompidos, adulterados ou alterados, os produtos subsumem-se a esta tipificação, quando estiverem: I - sem registro, quando exigível, no órgão de vigilância sanitária competente; II - em desacordo com a fórmula constante do registro previsto no inciso anterior; III - sem as características de identidade e qualidade admitidas para a sua comercialização; IV - com redução de seu valor terapêutico ou de sua atividade; V - com procedência ignorada; VI - sido adquiridos de estabelecimento sem licença da autoridade sanitária competente.

O artigo 273 do Código Penal, anteriormente, previa o crime de "alteração de substância alimentícia ou medicinal", alteração esta que podia ser realizada, conforme seu caput, pela (I) modificação da qualidade ou redução do valor nutritivo ou terapêutico; ou (II) supressão, total ou parcialmente, de qualquer elemento de sua composição normal, ou substituição por outro de qualidade inferior. Além disso, o $\S 1^{\circ}$ criminalizava a venda, exposição à venda, o depósito, ou qualquer forma de entrega a consumo das referidas substâncias. A pena cominada era de reclusão de um a três anos e multa para a modalidade dolosa e, conforme o $\S 2^{\circ}$ à modalidade culposa estabelecia-se a pena de detenção de dois a seis meses e multa.

A primeira expansão do artigo 273 do Código Penal ocorreu por meio da Lei $n^{\circ}$. 9.677 publicada em 2 de julho de 1998, que alterou sua redação, criminalizando as condutas de "falsificação, corrupção, adulteração ou alteração de produto destinado a fins terapêuticos ou medicinais". Não por acaso, menos de dois meses depois, em 20 de agosto de 1998 a Lei $n^{\circ} .9 .695$ altera a Lei $n^{\circ} .8 .072$ de 25 de julho de 1990, incluindo no rol de crimes hediondos o artigo 273 do CP em sua modalidade dolosa. 
É curioso observar que embora a Lei $\mathrm{n}^{\circ} .9 .677 / 98$ tenha alterado, também, o artigo 272 do CP, este não passou a ser elencado como hediondo. Isso não ocorreu por acaso, mas porque as referidas alterações legislativas ocorreram casuisticamente, logo após uma série de falsificações em medicamentos, dentre os quais, o episódio que ficou conhecido como o das "pílulas de farinha", que tratou da venda de comprimidos inócuos do contraceptivo Microvlar do laboratório Schering ${ }^{237}$; e o da falsificação do medicamento Androcur, utilizado no tratamento de câncer de próstata.

A desorientação da legislação penal brasileira, em especial, naquilo que se refere à tutela social frente à colocação de produtos no mercado de consumo, pode ser muito bem ilustrada pelo fato de que, atualmente, é considerado crime hediondo a conduta do agente que disponibiliza no mercado de consumo cosméticos ou saneantes, ainda que em escala comercial bastante reduzida, sem o devido registro. Trata-se de conduta tipificada no artigo $273 \S 1^{\circ}$-A do Código Penal e elencada no rol de crimes hediondos de acordo com a Lei $\mathrm{n}^{\circ}$ $8.072 / 90^{238}$.

O artigo 274 veda o emprego de revestimento, gaseificação artificial, matéria corante, substância aromática, anti-séptica, conservadora ou qualquer outra não expressamente permitida pela legislação sanitária, no fabrico de produto destinado a consumo. $\mathrm{O}$ artigo 275 , por sua vez, criminaliza a falsa indicação de substância que não se encontra em seu conteúdo ou que nele existe em quantidade menor que a mencionada, em invólucro ou recipiente de produtos alimentícios, terapêuticos ou medicinais. Em ambos os casos, comina-se a pena de um a cinco anos de reclusão e multa, assim como, à venda, exposição à venda, o depósito para venda ou qualquer forma de entrega dos referidos produtos.

Com pena de um a cinco anos de reclusão e multa apena-se o crime de venda, exposição à venda, depósito ou cessão de substância destinada à falsificação de produtos alimentícios, terapêuticos ou medicinais (art. 277). Tratando-se, porém, de substância nociva à saúde, ainda que não destinada à alimentação ou a fim medicinal, a pena cominada é de um a três anos de detenção e multa (art. 278), sendo reduzida para detenção de dois meses a um ano, em caso de conduta culposa.

\footnotetext{
${ }^{237}$ Este caso é amplamente detalhado no último capítulo do trabalho.

${ }^{238}$ Código Penal, Art. 273 - Falsificar, corromper, adulterar ou alterar produto destinado a fins terapêuticos ou medicinais. $\S 1^{\circ}$-A - Incluem-se entre os produtos a que se refere este artigo os medicamentos, as matériasprimas, os insumos farmacêuticos, os cosméticos, os saneantes e os de uso em diagnóstico. $\S 1^{\circ}$-B - Está sujeito às penas deste artigo quem pratica as ações previstas no $\S 1^{\circ}$ em relação a produtos em qualquer das seguintes condições: I - sem registro, quando exigível, no órgão de vigilância sanitária competente.
} 
Para finalizar, o fornecimento de substância medicinal em desacordo com a receita médica é conduta tipificada pelo art. 280, com pena prevista de um a três anos de detenção ou multa. À modalidade culposa é cominada a pena de detenção de dois meses a um ano. 


\section{A RESPONSABILIDADE PENAL SUBJETIVA NO CENÁRIO EMPRESARIAL. DIFICULDADES E CAMINHOS PARA SUA IMPUTAÇÃO DE ACORDO COM OS PARÂMETROS CONSTITUCIONAIS}

\subsection{A responsabilidade penal da Pessoa Jurídica}

O princípio societas delinquere non potest foi, aparentemente, excluído da ordem jurídica brasileira a partir da Constituição Federal de 1988 que, ao tratar dos princípios gerais da ordem econômica, em seu artigo $173 \S 5^{\circ}$, abre esta discussão ao dispor acerca da responsabilidade individual dos dirigentes do ente coletivo, além, da responsabilidade da própria pessoa jurídica:

“A lei, sem prejuizo da responsabilidade individual dos dirigentes da pessoa jurídica, estabelecerá a responsabilidade desta, sujeitando-a às punições compatíveis com sua natureza, nos atos praticados contra a ordem econômica e financeira e contra a economia popular".

No mesmo sentido, o artigo $225 \S 3^{\circ}$ :

"As condutas e atividades consideradas lesivas ao meio ambiente sujeitarão os infratores, pessoas físicas ou jurídicas, a sanções penais e administrativas, independentemente da obrigação de reparar os danos causados".

A doutrina brasileira se divide em relação ao referido tema, havendo opiniões de grande relevo defendendo, com argumentos bastante ponderados e convincentes, cada uma das posições ${ }^{239}$ : a adoção ou não pela Carta Política de 1988 da responsabilidade penal da pessoa jurídica.

Os constitucionalistas ${ }^{240}$, de um modo geral, entendem que é incontestável a vontade do legislador constitucional no sentido de adotar a responsabilidade penal da

\footnotetext{
${ }^{239}$ Por todos, defendendo a adoção da responsabilidade penal da pessoa jurídica: Sérgio Salomão Shecaira, Responsabilidade penal da pessoa jurídica. São Paulo: Ed. Revista dos Tribunais, 1998. p. 114. Contrário ao afastamento do princípio societas delinquere non potest: Miguel Reale Júnior, A responsabilidade penal da pessoa jurídica. In: PRADO, Luiz Regis; DOTTI, René Ariel. Responsabilidade penal da pessoa jurídica. 2. ed. rev. e atual. São Paulo: Ed. Revista dos Tribunais, 2010. p. 345.

${ }^{240}$ Neste sentido, José Afonso da Silva, Celso Ribeiro Bastos e Ives Gandra Martins.
} 
pessoa jurídica. Chegam a tal conclusão a partir de análise dos dispositivos acima referidos. Ao falar em responsabilidade em seu artigo $173 \S 5^{\circ}$, a Constituição estaria, segundo tal interpretação, fazendo referência, à responsabilidade penal, uma vez que prevê “punições compatíveis com sua natureza". Muitos penalistas ${ }^{241}$, por sua vez, entendem, em relação a este dispositivo, que se a Constituição quisesse falar em responsabilidade penal faria isso expressamente, não suprimindo o adjetivo "penal" ${ }^{242}$. JUAREZ CIRINO DOS SANTOS ${ }^{243}$, defendendo a segunda opinião, lembra que "o conceito jurídico de punição não é exclusivo do Direito Penal: abrange, também, sanções administrativas, com fins retributivos e preventivos, semelhantes às sanções penais e, às vezes - como é o caso das multas administrativas da Lei 9.605/98 -, com poder aflitivo e, portanto, retributivo muito superior ao de penas criminais..." 244.

Pode-se dizer, de qualquer modo, que o ordenamento jurídico brasileiro não prevê a possibilidade de imputação de responsabilidade penal à pessoa jurídica, a não ser nos casos de crimes contra o meio ambiente. A partir do mandamento constitucional do artigo $225 \S$ $3^{\circ}$, foi editada a Lei $n^{\circ} .9 .605$ de 12 de fevereiro de 1998, que dispõe acerca dos crimes contra o meio ambiente, trazendo a seguinte previsão em seu artigo $3^{\circ}$ :

"As pessoas jurídicas serão responsabilizadas administrativa, civil $e$ penalmente conforme o disposto nesta Lei, nos casos em que a infração seja cometida por decisão de seu representante legal ou contratual, ou de seu órgão colegiado, no interesse ou benefício da sua entidade”.

Muitos autores ${ }^{245}$ entendem que o supra referido dispositivo deve ser lido de modo que se interprete que as condutas lesivas ao meio ambiente sujeitarão as pessoas físicas a sanções penais, assim como, as atividades lesivas ao meio ambiente sujeitarão as pessoas jurídicas a sanções administrativas. Ou seja, o referido dispositivo deve ser interpretado como se houvesse o vocábulo "respectivamente" inserido em seu corpo: “... sujeitarão os

\footnotetext{
${ }^{241}$ Há diversos penalistas brasileiros que, embora discordem desta postura do legislador constitucional, entendem que a Carta Política de 1988 tenha adotado a Responsabilidade Penal da Pessoa Jurídica (...) e outros que entendem como adequada esta adoção (

${ }^{242}$ SANTOS, Juarez Cirino dos. Responsabilidade penal da pessoa jurídica. In: PRADO, Luiz Regis; DOTTI, René Ariel. op. cit., p. 266.

${ }^{243}$ Id. Ibid., p. 267.

${ }^{244}$ No mesmo sentido, Miguel Reale Júnior menciona a eficiência da punição de ordem administrativa, e fornece como exemplo a Lei 8.137/90 que prevê crimes contra a ordem econômica que não geram processos criminais, uma vez que as punições administrativas são suficientes e mais eficazes, neste âmbito, que as sanções penais. REALE JÚNIOR, Miguel. A responsabilidade penal da pessoa jurídica, cit., p. 345.

${ }^{245}$ Por todos, REALE JÚNIOR, Miguel. A responsabilidade penal da pessoa jurídica, cit., p. 343-345.
} 
infratores, pessoas físicas ou jurídicas, respectivamente, a sanções penais e administrativas...”.

MIGUEL REALE JÚNIOR sustenta, ainda, a inconstitucionalidade de imputação de responsabilidade penal à pessoa jurídica, mesmo na seara dos crimes contra o meio ambiente, e, neste sentido, chama a atenção para a interpretação sistemática da Constituição, que nos leva à impossibilidade de admissão da referida responsabilidade ${ }^{246}$.

REALE defende, deste modo, a incapacidade penal da pessoa jurídica evidenciada pelo texto constitucional. Elenca, neste sentido, no artigo $5^{\circ}$, os princípios da pessoalidade da pena ${ }^{247}$ e da individualização ${ }^{248}$ da pena que é aferida a partir da culpabilidade, o que torna impossível a aplicação de sanção penal à pessoa jurídica, ou seja, a um ente incapaz, por sua própria natureza, de externar a sua vontade estabelecida a partir de uma seleção axiológica $^{249}$.

Os principais argumentos contrários à imputação de responsabilidade penal aos entes coletivos estão inseridos no contexto da incongruência desta forma de responsabilização com o nosso sistema criminal. São eles: a impossibilidade da conduta, da qual depende a existência do crime, ser praticada pelo ente moral; a afronta ao princípio da pessoalidade da pena; a impossibilidade de aplicação do princípio da individualização da pena; o descabimento da utilização do Direito Penal em uma seara onde seria impossível a concretização das funções da pena criminal; a inadequação dos instrumentos processuais penais garantistas na disposição de pessoa jurídica como ré.

A presença de conduta é o primeiro elemento analisado na aferição da tipicidade e sem ela, não há que se falar em delito. Antes de se falar em conduta da pessoa jurídica, deve-se enfrentar o tema relativo à natureza dos ditos entes. Esta matéria tem como principais teóricos FREDERICH KARL VON SAVIGNY e OTTO GIERKE, com posições opostas. O primeiro, defensor da teoria ficcionista, entende que as pessoas jurídicas nada mais são que ficções criadas por lei. O último, por outro lado, defensor da teoria realista, entende tratarem-se de organismos sociais, como as pessoas naturais, possuindo, neste sentido, vontade própria. Entende-se ser acertada a posição de SAVIGNY

\footnotetext{
${ }^{246}$ REALE JÚNIOR, Miguel. A responsabilidade penal da pessoa jurídica, cit., p. 344.

${ }^{247} \mathrm{CF}$, art. $5^{\circ}, \mathrm{XLV}$ : "Nenhuma pena passará da pessoa do condenado, podendo a obrigação de reparar o dano e a decretação do perdimento de bens ser, nos termos da lei, estendidas aos sucessores e contra eles executadas, até o limite do valor do patrimônio transferido".

${ }^{248} \mathrm{CF}$, art. $5^{\circ}$, XLVI: "A lei regulará a individualização da pena...”.

${ }^{249}$ REALE JÚNIOR, Miguel. A responsabilidade penal da pessoa jurídica, cit., p. 344.
} 
que vê na pessoa jurídica uma ficção legal, conveniente em determinadas situações da vida civil, mas incompatível por sua própria natureza à responsabilidade penal.

O ente moral é incapaz de, per si, praticar conduta, uma vez que esta é intimamente ligada à capacidade de culpabilidade, exclusiva da pessoa natural. Se há dúvidas quanto à possibilidade das pessoas jurídicas agirem, não restam dúvidas de que, se agem, o fazem através de pessoas naturais (funcionários, diretores, prepostos) e em decorrência de sua vontade. A própria Lei 9.605/98 condiciona a punição da pessoa jurídica à tomada de decisão de representante ou de órgão colegiado ${ }^{250}$, o que demonstra sua total submissão à ação de pessoa natural e torna despicienda até mesmo a mera cogitação da responsabilidade penal do ente ficto.

A oposição que se faz a seguir, diz respeito ao princípio da pessoalidade da pena, disposto na Constituição Federal, artigo $5^{\circ}$, XLV, que veda que qualquer pena passe da pessoa do condenado, ou seja, que transcenda o autor ou partícipe do delito. Sendo impossível à pessoa jurídica a prática de ação no sentido jurídico-penal, seria violado o princípio da pessoalidade da pena se o ente moral sofresse pena por ação cometida por pessoa natural, ainda que em seu nome. O princípio em tela não diz respeito, como querem fazer parecer os defensores da responsabilidade penal da pessoa jurídica, aos efeitos sócioeconômicos da pena sobre terceiros, seja a família do apenado, sejam, em caso de condenação penal do ente coletivo, os acionistas ou funcionários da empresa. Como bem lembra JUAREZ CIRINO DOS SANTOS, o princípio da pessoalidade da pena veda que haja imposição de sanção penal a pessoa diversa da que praticou o crime e não que os efeitos desencadeados pelo cumprimento da pena atinjam terceiros ${ }^{251}$. A privação de liberdade ou a privação de direitos de um réu não se estende à sua família, mas esta, eventualmente, poderá sofrer os efeitos sócio-econômicos decorrentes do cumprimento da pena por um de seus membros.

Suscita-se, ademais, a impossibilidade de aplicação do princípio da individualização da pena determinado pelo artigo $5^{\circ}$, XLVI, da carta constitucional brasileira e definida pelo Código Penal. O caput do artigo 59 do CP manda que "o juiz, atendendo à culpabilidade, aos antecedentes, à conduta social, à personalidade do agente, aos motivos, às circunstâncias e conseqüências do crime, bem como ao comportamento da

\footnotetext{
${ }^{250}$ Lei no ${ }^{\circ}$ 9.605/98, art. $3^{\text {o: }}$ "As pessoas jurídicas serão responsabilizadas administrativa, civil e penalmente conforme o disposto nesta Lei, nos casos em que a infração seja cometida por decisão de seu representante legal ou contratual, ou de seu órgão colegiado, no interesse ou benefício da sua entidade".

${ }^{251}$ SANTOS, Juarez Cirino dos. op. cit., p. 280.
} 
vítima”, estabeleça a pena, necessária e suficiente para reprovação e prevenção do crime. Não há, no entanto, que se falar em culpabilidade, antecedentes, conduta social e personalidade de ente coletivo, sendo, por isso, impossível proceder à sobredita individualização, numa afronta ao texto constitucional.

Continuando nesta linha de raciocínio, por tratar-se de mera ficção jurídica, o ente coletivo é incapaz de ser alcançado pelas funções preventivas e retributivas conferidas à pena criminal, fato que, por si só, já seria suficiente para torná-la inaplicável.

Por último, cabe lembrar a inadequação dos instrumentos processuais penais garantistas na acusação de pessoa jurídica. Uma vez que não há regras processuais específicas para serem utilizadas com os entes morais, diversos daqueles previstos para as pessoas naturais, resta a adoção das mesmas regras e procedimentos em ambos os casos, ou seja, independente da natureza do réu. Inúmeras são as dúvidas e imprecisões que surgem na esfera processual e, desta forma, bem conclui RENÉ ARIEL DOTTI, "princípios e regras da maior importância, como os relativos à investigação, à verdade material, à concentração e à imediação, serão gravemente comprometidos pela aventura de se perseguir a pessoa coletiva como causadora de um evento delituoso" 252.

Os países que admitem a adoção da sobredita imputação são, em geral ${ }^{253}$, aqueles regidos pelo direito anglo-saxão, onde há um sistema jurídico de common law, compatível com este modelo de responsabilização ${ }^{254}$. A justiça criminal brasileira baseada, de outro modo, em um sistema legal codificado possui diversos impedimentos, por sua própria metodologia a esta previsão, fato que não evitou que o Brasil viesse a prevê-la em sua carta constitucional e, posteriormente, em lei, o que acaba por trazer grande dificuldade de aplicação prática $^{255}$.

Os crimes contra as relações de consumo ou qualquer conduta delituosa, fora do âmbito de proteção da Lei nº 9.605/98, da qual decorra perigo ou lesão à vida, à saúde ou

\footnotetext{
${ }^{252}$ DOTTI, René Ariel. A incapacidade criminal da pessoa jurídica. In: PRADO, Luiz Regis; DOTTI, René Ariel. op. cit., p. 182.

${ }^{253}$ A França, por exemplo, é exceção a esta regra, mas, para instituir a Responsabilidade Penal da Pessoa Jurídica em sua ordem legal, fez adaptações em todo o seu sistema penal de. Neste sentido, editou-se a Lei 92-1339/1992, chamada de Lei de Adaptação, conferindo lógica e viabilidade a esta forma de responsabilização criminal. No Brasil, ao contrário, não houve este cuidado. PRADO, Luiz Regis. Responsabilidade penal da pessoa jurídica: fundamentos e implicações. In: PRADO, Luiz Regis; DOTTI, René Ariel. op. cit., p.149.

${ }^{254}$ A responsabilidade penal da pessoa jurídica nos Estados Unidos da América, por exemplo, como lembra LUIZ LUISI, se fundamenta "na Strict Liability, ou seja, na responsabilidade penal sem culpa. Trata-se de um sistema que consagra a responsabilidade pena objetiva." LUISI, Luis. Notas sobre a responsabilidade penal das pessoas jurídicas. In: PRADO, Luiz Regis; DOTTI, René Ariel. op. cit., p. 29.

${ }^{255}$ SANTOS, Juarez Cirino dos. op. cit., p. 265.
} 
à integridade física, estão, de qualquer modo, até o presente momento, fora da esfera de possibilidade de imputação de responsabilidade penal à pessoa jurídica no ordenamento jurídico brasileiro.

Para que, um crime cometido por meio da utilização de cadeia empresarial não fique sem resposta na esfera penal, portanto, é necessária a aferição da responsabilidade subjetiva pela conduta (ou condutas) que gerou o resultado delituoso. A dificuldade que apresenta este tipo de investigação não pode ser desculpa para que não se busque a responsabilidade específica dentro da empresa.

\subsection{Autoria e participação na sociedade empresária}

Entende-se por empresa, conforme o art. 966 do Código Civil, atividade econômica organizada para a produção ou a circulação de bens ou de serviços. Esta atividade é estruturada pelos desígnios de pessoas naturais que adequam seu funcionamento a uma organização predeterminada, seja legalmente, seja por meio de especificações constantes em contrato social ou estatuto. Deve-se, por esta razão, fazer referência à sociedade empresária, composta e dirigida por indivíduos, capazes de praticar, em suas áreas de domínio, de acordo com suas reflexões e decisões, condutas comissivas ou omissivas e não à empresa já que esta diz respeito à mera atividade.

Dentre as diversas dificuldades que são apresentadas ao longo da tentativa de se imputar a responsabilidade penal àqueles que atuam na cadeia empresarial, pelo perigo ou lesão causada por produto a bem jurídico do consumidor, a questão da determinação da autoria criminosa nesta seara é, certamente, a mais complexa. Isso ocorre, pois, diversamente do que ocorre em outros ramos do direito, a responsabilidade penal deve, além de respeitar diversos princípios penais constitucionais, ser obrigatoriamente subjetiva.

Embora seja importante ressaltar que a criminalidade empresarial é complexa, notadamente, naquilo que se refere à autoria, sua não regulação no mundo moderno pode trazer consequências irrefreáveis, especialmente, naquilo que diz respeito à colocação de produtos no mercado de consumo. Nos crimes praticados tendo como cenário a sociedade 
empresária, os agentes não se associam com a finalidade da prática delitiva, mas, acabam praticando infração penal no exercício de suas funções ${ }^{256}$.

Conforme a redação do caput do artigo 29 do Código Penal, "quem, de qualquer modo, concorre para o crime incide nas penas a este cominadas, na medida de sua culpabilidade". A expressão “de qualquer modo", abre a possibilidade de ampla interpretação, subsunção de condutas e modos de exercício da autoria e da participação delitiva, aí incluídas diversas formas de atuação na seara empresarial. Por outro lado, a expressão "na medida de sua culpabilidade" individualiza a responsabilidade de cada um dos agentes em caso de coparticipação criminosa, podendo, diminuir ou até excluir o caráter criminoso de cada conduta especificamente considerada.

O caput do artigo 13, por sua vez, determina que "o resultado, de que depende a existência do crime, somente é imputável a quem lhe deu causa", e completa "considera-se causa a ação ou omissão sem a qual o resultado não teria ocorrido". No que concerne à omissão, entende-se como penalmente relevante, conforme o $\S 2^{\circ}$, quando o omitente devia e podia agir para evitar o resultado, sendo considerados obrigados a agir aqueles que: tenham por lei obrigação de cuidado, proteção ou vigilância; de outra forma, tenham assumido a responsabilidade de impedir o resultado; ou, com comportamento anterior, tenham criado o risco da ocorrência do resultado. Exclui-se a responsabilidade pelo resultado, no entanto, a superveniência de causa relativamente independente que tenha, por si só, produzido o resultado, sendo resguardada a imputação de fatos anteriores a quem os tenha praticado, de acordo com o $\S 1^{\circ}$.

Não se deve restringir a análise da autoria, portanto, a mera aferição do nexo causal, objetivamente verificado. Deve-se observar, também, "o acordo de vontades, visando a um fim comum, do qual participam autor e cúmplice, devendo cada qual responder na medida de sua culpabilidade", conforme lição de MIGUEL REALE JÚNIOR $^{257}$.

A evolução do conceito de autoria permite o elenco de três conceitos de autor: conceito amplo, conceito restrito e conceito funcional ${ }^{258}$. O conceito amplo admite como autor toda pessoa que tenha contribuído causalmente para a realização do resultado

\footnotetext{
${ }^{256}$ FERRAZ, Esther de Figueiredo. A co-delinquência no moderno direito penal brasileiro. São Paulo: José Bushatsky, 1976. p. 88.

${ }^{257}$ REALE JÚNIOR, Miguel. Instituições de direito penal: parte geral. 3. ed. Rio de Janeiro: Forense, 2009. p. 311.

${ }^{258}$ TAVARES, Juarez. Autoria e participação: apontamentos de aula. UERJ, 2009. p. 2. Disponível em: $<$ http://www.juareztavares.com/Textos/apontamentos_autoria.pdf>. Acesso em: 14 dez. 2010.
} 
delituoso. Conforme o conceito restrito, autor é quem realiza a conduta típica, não importando as circunstâncias subjetivas do fato. De acordo com o conceito funcional, não basta à condição de autor, que o agente tenha praticado a ação típica, devendo-se considerar a atuação de cada um dos atores para a definição de seu papel de autor ou partícipe.

Mais adequado à realidade é, portanto, o chamado conceito funcional de autoria, que além de considerar os elementos objetivos, considera, também, os subjetivos. Trata-se de consequência das formulações material-objetiva e final-objetiva ${ }^{259}$. A primeira diferencia autoria de participação a partir da relevância causal das condutas praticadas por cada um dos agentes ${ }^{260}$, enquanto a última, considera autor apenas o agente que, na lição de NILO BATISTA, "na concreta realização do fato típico, conscientemente o domina, mediante o poder de determinar o seu modo, e inclusive, quando possível, de interrompê$10 " 261$.

Entende-se, seguindo esta linha de raciocínio, que autor é aquele que tem o domínio do fato criminoso, desdobrado em quatro vertentes: domínio da ação, que se relaciona à autoria direta; domínio da vontade e domínio por força de conhecimento especial, ambos associados à autoria mediata; e domínio funcional do fato, encontrado na coautoria. Conforme MIGUEL REALE JÚNIOR “autor, portanto, será aquele que, como figura central da prática da ação típica, tem o domínio do fato, ou seja, é a quem pertence a obra realizada, a quem se atribui a ação, visto exercer de modo efetivo e atual a soberania de configuração da ação, no dizer de BOTTKE",262.

Para a teoria funcional da autoria, também chamada de teoria do domínio do fato, segundo a definição formulada por WESSELS-BEULKE e citada por JUAREZ TAVARES, autor é "quem, como figura central do acontecimento, detém o domínio do fato como seu dirigente ou coexecutor, de tal modo que possa impedir ou deixar seguir a realização do tipo conforme sua vontade". E completa Tavares, definindo como partícipe "todo aquele que não se enquadrar nesses elementos (...), uma figura secundária ao acontecimento" 263.

\footnotetext{
${ }^{259}$ TAVARES, Juarez. op. cit., p. 3.

${ }^{260}$ BATISTA, Nilo. Concurso de agentes: uma investigação sobre os problemas da autoria e da participação no direito penal brasileiro. 4. ed. Rio de Janeiro: Lumen Juris, 2008. p. 65.

${ }^{261}$ Id. Ibid., p. 69.

${ }^{262}$ REALE JÚNIOR, Miguel. Instituições de direito penal: parte geral, 3.ed., cit., p. 312.

${ }^{263}$ TAVARES, Juarez. Autoria e participação: apontamentos de aula. UERJ, 2009, cit., p. 7.
} 
HANS WELZEL determinou o domínio finalista do fato como característica geral do conceito de autor. Ou seja, o autor é visto por ele como dono do fato, "quem o executa em forma finalista, sobre a base de sua decisão de vontade" ${ }^{264}$. Pode-se entender HANS WELZEL como o fundador da teoria do domínio do fato, pois é dele o mérito de tê-la feito exercer alguma influência efetiva no mundo jurídico-penal ${ }^{265}$. A teoria do domínio do fato $^{266}$ foi posteriormente desenvolvida por CLAUS ROXIN e é hoje adotada pela maioria da doutrina.

Como já mencionado anteriormente, ao falarmos em domínio do fato, podemos considerar quatro áreas distintas: o domínio da ação, o domínio da vontade, o domínio por força de conhecimento especial e, ainda, o domínio funcional do fato.

A autoria por domínio da ação é a forma elementar da autoria. Ocorre sempre que um sujeito em condições regulares de imputabilidade - ou seja, em plena capacidade de compreensão ético-jurídica e de autodeterminação - e sem estar coagido, executa, pessoalmente, todos os elementos do tipo. É a autoria direta do fato criminoso ${ }^{267}$.

O domínio da vontade, que diz respeito à autoria mediata, pode ocorrer em virtude de coação ou de erro causado por um desconhecimento. $\mathrm{O}$ autor, neste caso também chamado de homem de trás, não executa o fato delituoso, utilizando, para tal, alguém que serve a ele como instrumento, o autor imediato ou direto ${ }^{268}$.

Para Roxin, além dos casos de coação e erro, pode-se chegar à autoria mediata por domínio da vontade em virtude de aparatos organizados de poder. Essa hipótese, aventada no pós-guerra pela jurisprudência alemã, diz respeito aos casos em que o homem de trás tem a seu dispor uma estrutura, geralmente estatal, para a prática de delitos, não necessitando delegar a sua prática à decisão autônoma do executor ${ }^{269}$.

A figura da autoria mediata mediante o domínio da vontade em virtude de estruturas organizadas de poder demanda o preenchimento de uma série de requisitos para

\footnotetext{
${ }^{264}$ WELZEL, Hans. Direito penal. Trad. Afonso Celso Rezende. Campinas: Romana, 2003. p. 158.

${ }^{265}$ ROXIN, Claus. A autoría y dominio del hecho em derecho penal. Trad. Joaquín Cuello Contreras y José Luis Serrano González de Murillo. 7. ed. Madrid: Marcial Pons, 2000. p. 86.

${ }^{266}$ Segundo Roxin, Hegler é o primeiro autor a fazer referência à expressão "domínio do fato" em Direito Penal, em 1915, porém, com significado diverso do que possui hoje, restrito aos elementos materiais da culpabilidade jurídico-penal, daí consideradas imputabilidade, dolo e culpa, bem como, as causas de exculpação. Para Hegler, haveria culpabilidade quando houvesse, por parte do agente, o pleno domínio do fato, ou seja, aquele que fosse senhor do fato em sua concreta manifestação. ROXIN, Claus. A autoría y dominio del hecho em derecho penal, cit., p. 81.

${ }^{267}$ Id. Ibid., p. 151.

${ }^{268}$ Id. Ibid., p. 166.

${ }^{269}$ Id. Ibid., p. 270.
} 
que possa ser aplicada: a sólida estrutura hierárquica; a presença de um significativo número de membros que garanta a intercambialidade do executor em caso de recusa em realizar a ação determinada; e a desvinculação da estrutura de poder do ordenamento jurídico do Estado onde se encontra situada. Neste sentido, PATRICIA FARALDO CABANA a admite a possibilidade de utilização deste modelo no âmbito da empresa, mas determina que só possa ser cogitado nos casos em que haja o deslocamento do objeto empresarial para a prática delitiva, ou seja, quando a empresa passa a ter como atividade única ou principal a prática de delitos ${ }^{270}$. Embora a jurisprudência alemã já a tenha adotado nesta seara, a doutrina, inclusive CLAUS ROXIN, a rejeita ${ }^{271}$.

Para que seja possível aferir-se a quem cabe imputar a responsabilidade por um resultado proibido decorrente de produto defeituoso, deve-se verificar, inicialmente, o nexo causal entre o produto e a produção do resultado. A seguir, afere-se a procedência do produto. Por último verifica-se a quem coube a decisão da colocação daquele produto no mercado de consumo, verificando, também, quem são os responsáveis técnicos por seu desenvolvimento.

Segundo VOGEL, ainda que fabricantes e comerciantes sejam, em geral, pessoas jurídicas, a responsabilidade penal demanda um comportamento relevante de pessoa natural $^{272}$. Por este motivo, o $\mathrm{BGH}$ desenvolveu os princípios para a imputação de responsabilidade penal dentro de uma organização ${ }^{273}$. Dentre eles:

(I) A responsabilidade penal deve, a princípio ser imputada aos membros da direção da empresa, responsáveis pelas tomadas de decisão em seu âmbito e não aos funcionários ou empregados;

(II) $\mathrm{O}$ diretor pode ser responsabilizado por conduta comissiva ou omissiva limitada ao âmbito de responsabilidade que lhe foi confiada e que é possível e exigível. A ação de produção ou comercialização do produto é a finalidade da empresa. Por isso, trata-se de crime próprio do diretor ou administrador. A omissão da retirada do produto perigoso do mercado de consumo, do mesmo modo, é própria do diretor ou administrador. Há casos, no entanto, em que se requerem comportamentos que vão

\footnotetext{
${ }^{270}$ FARALDO CABANA, Patricia. Posibilidades de aplicación de la autoría mediata con aparatos organizados de poder en la empresa. Disponível em: <http://www.alfonsozambrano.com/>.

${ }^{271}$ Para maiores detalhes acerca da autoria mediata na seara empresarial, ver:

${ }^{272}$ VOGEL, Joachim. La responsabilidad penal por el producto en Alemania: situación actual y perspectivas de futuro. Revista Penal La Ley, Salamanca, n. 8, p. 97, jul. 2008.

${ }^{273}$ Id., loc. cit.
} 
além da competência própria de cada administrador. No caso, por exemplo, em que haja a necessidade de conhecimentos técnicos específicos.

(III) Muitas vezes, há a presença de responsabilidade conjunta advinda de decisões tomadas no âmbito de órgãos colegiados. Decide-se com base nos critérios de causalidade e imputação objetiva: o voto que contribuir para a aprovação da decisão é, ao menos, concausa do resultado, independentemente de ter sido este voto necessário à formação da maioria. O votante é penalmente responsável.

(IV) Nos delitos dolosos, cada votante é coautor, ou seja, o resultado é atribuído ao conjunto das ações (neste caso, ao conjunto de votos), e não a cada uma delas de forma singular. Não importa a ordem da votação nem quais votos ocorrem após a formação da maioria.

Ainda que se defenda a necessidade de imputação de responsabilidade penal por decisão tomada no âmbito empresarial, não se pode cogitar a presença de responsabilidade penal objetiva, havendo, por isso, a obrigação de se aferir, além do nexo causal entre a conduta - comissiva ou omissiva, dolosa ou culposa - e o resultado; a ausência de excludente ou justificação; e, por último, a culpabilidade de cada um dos que participaram para a tomada de decisão.

É importante que se ressalte que, conforme lição de SCHÜNEMANN, tradando-se a omissão da não realização de uma conduta ativa, só se poderá falar em omissão de uma conduta se for possível ao autor individual realizá-la. E mais: só se pode cogitar a evitação de lesão a um bem jurídico se a realização da ação de salvamento por parte do autor se houver probabilidade próxima à certeza de resgate do bem jurídico ${ }^{274}$.

Outro ponto a ser considerado ao falarmos em autoria, é que devemos ter em mente a quem coube a criação do risco para o bem jurídico. Quem, agindo culposa ou dolosamente, submeteu o consumidor a um risco que exceda sua legítima expectativa, ou seja, um risco que ele não pode imaginar nem calcular e, até por isso, não aceitou assumir.

A verificação do âmbito de responsabilidade de cada pessoa dentro da empresa e, em especial, a capacidade pela tomada de decisão, ainda que difíceis na prática ${ }^{275}$, parecem

\footnotetext{
${ }^{274}$ SCHÜNEMANN, Bernd. El llamado delito de omisión impropria o la comisión por omisión. In: GARCÍA VALDÉS, Carlos et al (Coord.). Estudios penales en homenaje a Enrique Gimbernat II. Madrid: Edisofer, 2008. t. 2, p. 1614.

${ }^{275}$ Conforme referido por Susana Aires de Sousa, Schünemman entende que "a descentralização das decisões (e de sua execução) nas empresas de hoje comporta o risco de converter a organização da responsabilidade
} 
ser o critério mais adequado à aferição e limitação da responsabilidade penal na cadeia empresarial. A conduta geradora de responsabilidade penal pela produção ou comercialização de produtos pode ser comissiva ou omissiva, dolosa ou culposa. Os casos mais relevantes derivam de infração a um dever objetivo de cuidado ou de garantia, ou seja, comportamentos culposos ou omissivos.

Ao saber que seu produto, mesmo quando utilizado conforme as regulares condições de uso, apresenta potencial lesivo à vida ou integridade física do consumidor, o produtor ou comerciante deve evitar a realização do resultado, mediante sua retirada do mercado de consumo ${ }^{276}$, pois é a colocação do produto perigoso no mercado o coloca em posição de garante. A mera suspeita de perigo iminente é insuficiente para se afirmar presente o dolo, mas bastante para estabelecer a culpa quando o responsável confia na inocuidade do produto ${ }^{277}$.

Para que alguém assuma a posição de garante é necessária uma condição anterior, ou seja, uma conduta anterior que tenha causado o risco de lesão ao bem jurídico penalmente tutelado. No caso em questão, a conduta anterior causadora de risco é a produção ou colocação do produto no mercado de consumo.

O Supremo Tribunal alemão entende não ser necessário um comportamento prévio culpável, por descumprimento do dever objetivo de cuidado. Basta a mera desaprovação jurídica do resultado de perigo. Ou seja, não se exige que o comportamento perigoso seja juridicamente reprovável $^{278}$.

Para o BGH, a desaprovação jurídica do resultado de perigo da fabricação ou comercialização de produtos potencialmente lesivos, na Alemanha, decorre: (I) do princípio neminem laedere; (II) da proteção constitucional da vida e da integridade física; (III) de preceitos legais específicos, como alguns os constantes na Lei de Alimentos ${ }^{279}$.

Será feita, adiante, a análise de cada possibilidade de atuação dentro da empresa que gerar o defeito de produtos decorrente de fabricação ou comercialização.

em irresponsabilidade organizada". SOUSA, Susana Aires de. Responsabilidade criminal por produtos defeituosos. Revista Brasileira de Ciências Criminais, São Paulo, v. 17. n. 76, p. 120, jan./fev. 2009.

${ }^{276}$ VOGEL, Joachim. op. cit., p. 97.

${ }^{277}$ Id. Ibid., p. 98.

${ }^{278}$ Id. ibid., p. 97.

${ }^{279}$ Id. Ibid., p.98. 


\subsection{A responsabilidade no cenário empresarial. A capacidade de tomada de decisão}

Afastada a possibilidade de imputação de responsabilidade penal à pessoa jurídica, deve-se aferir, no âmbito da empresa, se há alguém - pessoa natural - que deva ser responsabilizado pelo resultado delituoso. São inúmeras as dificuldades que se apresentam nessa aferição, mas, tais dificuldades não podem se constituir desculpas para que não se busque um (ou mais de um) responsável. É importante ressaltar que a imputação de responsabilidade deve ser sempre pautada pelos princípios fundamentais que regem o Direito Penal.

SCHÜNEMANN entende que embora, muitas vezes, haja dificuldades de se imputar a responsabilidade penal aos diretores da empresa, não se pode eliminar a necessidade e possibilidade da aferição de responsabilidade individual ${ }^{280}$. Por esta razão, as empresas devem ter em seus regimentos a cadeia de responsabilidades esclarecida, onde começam e até onde vão as competências de cada um de seus diretores, executores e funcionários em geral.

Embora haja, segundo SCHÜNEMANN uma disposição jurisprudencial, doutrinária e legal ${ }^{281}$ de se atribuir a responsabilidade penal em "top-down" 282 ", "hacia arriba", ou seja, de se responsabilizar em um primeiro momento os diretores e, em seguida, os executores $^{283}$, deve-se pautar a aferição da responsabilidade nesta seara, tendo-se como parâmetro a impossibilidade de se responsabilizar alguém pelo simples fato de ocupar um cargo de direção em uma empresa que, em decorrência de sua atividade acabou gerando um resultado ilícito. Deve-se, ao contrário, aferir quem, na cadeia de responsabilidades dentro da referida empresa foi o autor da conduta, dolosa ou culposa, em consequência da qual o bem jurídico penalmente protegido foi exposto a perigo ou mesmo lesionado.

Para que não seja inconstitucionalmente imputada, a responsabilidade penal, sempre subjetiva, deve atender a uma série de critérios, dentre os quais, a verificação da existência de conduta dolosa ou culposa, resultado, e nexo de causalidade ligando ambos.

\footnotetext{
${ }^{280}$ SCHÜNEMANN, Bernd. Responsabilidad penal en el marco de la empresa: dificultades relativas a la individualización de la imputación. Anuario de derecho penal y ciencias penales. ; Boletín Oficial del Estado, Madrid: Ministerio de Justicia, t. 55, n. 1, p. 13, 2002.

${ }^{281}$ Id. Ibid., p. 11. Na legislação brasileira, encontram-se exemplos desta tendência tanto no Código de Defesa do Consumidor quanto na Lei ${ }^{\circ}$. 8.137/90.

${ }^{282}$ FEIJOO SÁNCHEZ, Bernardo. Cuestiones actuales de derecho penal econômico. Buenos Aires: Julio César Faira Ed., 2009. p. 8.

${ }^{283}$ SCHÜNEMANN, Bernd. Responsabilidad penal en el marco de la empresa: dificultades relativas a la individualización de la imputación, cit., p. 10.
} 
Para que a pessoa a quem cabe a capacidade pela tomada de uma específica decisão possa, enfim, decidir, é necessário que saiba exatamente sobre o quê está decidindo, entre quais opções e quais os riscos que correrá com seu ato. $\mathrm{O}$ ambiente empresarial, cada vez mais complexo, torna a cada dia mais difícil a aferição da responsabilidade individualizada. Devem ser consideradas as questões de hierarquia, divisão de trabalho e responsabilidades e a capacidade de tomada de decisão em cada um dos setores da empresa. É de se frisar, porém, que, estando dentro dos limites pelos quais responde pessoalmente dentro da empresa, o agente, capaz de tomar uma decisão em decorrência de sua função, não pode, evidentemente, alegando o desconhecimento da situação de fato, fugir à responsabilidade pela decisão tomada.

\subsubsection{Teoria da Decisão}

Faz-se necessário o estabelecimento de determinados parâmetros para que se possa apurar a quem a responsabilidade deve ser imputada.

Pode-se entender como penalmente imputável a alguém, o resultado advindo das condutas praticadas em razão das decisões tomadas por esta pessoa, no âmbito de sua responsabilidade, seja ela individual ou dependente da decisão de outras pessoas, dentro da cadeia da empresa.

Trazida da Administração Empresarial, a Teoria da Decisão nos traz a resposta, pelo menos em parte, para a determinação da dita responsabilidade.

De acordo com o Professor LUIZ FLAVIO AUTRAN MONTEIRO GOMES ${ }^{284}$, a decisão, de acordo com a referida teoria, pode ser dividida em dois níveis: no primeiro há a presença dos técnicos em determinado assunto e no segundo estão presentes os diretores da empresa que têm a efetiva responsabilidade de decidir, mas que se apóiam na perícia do primeiro grupo. Ambas as esferas são geradoras de responsabilidade. Podemos verificar, neste sentido, a presença de alguns distintos agentes ${ }^{285}$ :

\footnotetext{
${ }^{284}$ GOMES, Luiz Flavio Autran Monteiro. Teoria da decisão. São Paulo: Thomson, 2006. p. 56. (Coleção debates em administração).

${ }^{285}$ Id. ibid., p. 62.
} 
(a) tomador de decisão ou decisor: pode ser uma ou mais pessoas (um órgão colegiado, por exemplo) e é o responsável final pela decisão a ser tomada. É para ele que se é produzida a recomendação sobre que decisão deve ser tomada.

(b) O agente de decisão: é a pessoa ou as pessoas que detêm conhecimento técnico e, por isso, podem emitir um juízo de valores que será utilizado na análise da decisão.

(c) O analista de decisão: é alguém que conhece a teoria da decisão e após a análise dos dados emitidos pelos agentes da decisão, aconselham o decisor com quem exerce uma atividade complementar. No entanto, a responsabilidade pela tomada de decisão é exclusivamente do primeiro.

Não há que se falar de imputação de responsabilidade penal ao analista da decisão, que apenas avalia dados técnicos emitidos pelos agentes da decisão e aconselha, com base em critérios econômicos e empresariais, o tomador de decisão.

Devem-se, deste modo, entender como penalmente responsáveis apenas os tomadores de decisão e os agentes de decisão. Ou seja, os que decidem efetivamente e os que são peritos nas matérias importantes à formação da decisão.

Ressalte-se que os tomadores e agentes de decisão podem ter responsabilidades concorrentes ou excludentes. Se o agente, que nada mais é do que um responsável técnico, um perito, informa equivocadamente ao decisor que, por isso, e por confiar em sua capacidade profissional, toma decisão potencialmente lesiva, apenas será responsável o agente. O decisor só passará a ser responsável se, após o conhecimento do potencial lesivo de seu produto não proceder sua retirada do mercado de consumo. Pode-se verificar que, de um modo geral, o agente responderia por crime por conduta imperita.

Um caso que exemplifica a presença de responsabilidade exclusiva do agente de decisão é o do brinquedo Aqua Dots cuja nocividade era causada pelo equívoco na escolha dos componentes químicos utilizados na fabricação do brinquedo que acabava por liberar uma droga chamada GHB, conhecida como "ecstasy líquido" 286.

\footnotetext{
${ }^{286}$ Este caso é relatado detalhadamente no último Capítulo do trabalho.
} 


\subsubsection{Divisão de responsabilidades e o Princípio da Confiança}

Ao longo da cadeia empresarial, há ou deveria haver, a divisão de tarefas, de forma hierarquizada e com responsabilidades preestabelecidas e delimitadas. Não se pode, por óbvio responsabilizar alguém por resultado decorrente de fato ocorrido fora de sua esfera de responsabilidade e possibilidade de atuação.

Por outro lado, há que se verificar que cada um dos que atua no âmbito da empresa, tem como certa a correta e lícita atuação por parte dos outros membros. Ou seja, se, por exemplo, o farmacêutico responsável pelos medicamentos de uma empresa formula um composto para a fabricação de um medicamento que, posteriormente, é fabricado de maneira equivocada, com doses de cada princípio ativo diferentes das determinadas por ele em decorrência de equívoco do funcionário responsável pelo controle de qualidade da fabricação. O farmacêutico, por óbvio, não pode ser responsabilizado pela eventual produção de efeitos indesejados pelo referido produto, cabendo a responsabilidade ao técnico, ao menos, culposamente, pois não poderia prever a atuação equivocada de outro membro da cadeia produtiva.

O critério estabelecido pelo Princípio da Confiança, para que seja determinada a medida do dever de cuidado no caso de atividades compartilhadas, segundo EUGENIO RAÚL ZAFFARONI, entende como "conforme ao dever de cuidado a conduta do que confia em que o outro se comportará prudentemente, até que não tenha razão suficiente para duvidar ou crer o contrário". Há a necessidade da verificação da existência de múltiplas ações voltadas para a prática da mesma atividade, para que se possa excluir a possibilidade do descumprimento do dever de cuidado em decorrência do Princípio da Confiança.

\subsubsection{Decisões tomadas individualmente ou por meio de órgãos colegiados}

Responsabilizar criminalmente aquele que tenha tomado uma decisão capaz de colocar em risco ou lesionar a saúde, a integridade física ou a vida de alguém não é muito diferente do que se faz corriqueiramente no Direito Penal. Ao falar-se em decisão tomada 
individualmente, não surgem dúvidas: a responsabilidade por eventuais riscos ou lesões é daquele que a tomou.

$\mathrm{Na}$ seara da responsabilidade penal na seara empresarial, no entanto, mais um obstáculo é percebido. Trata-se da responsabilidade decorrente de decisão tomada no âmbito do órgão colegiado.

Se o resultado depende apenas de unanimidade não há maiores questionamentos, sendo todos responsáveis. Surgem dúvidas, no entanto, ao tratar de decisões constituídas por maioria, se devem ser considerados causa do resultado cada um dos votos proferidos ainda que após a formação da maioria necessária à decisão tomada. Parte da doutrina entende que esse tipo de imputação seria equivocado uma vez que seria irrelevante à obtenção do resultado.

Para resolver este problema, no entanto, deve-se recorrer ao critério da causalidade cumulativa, explicado adiante, entendendo como coautores cada um dos votantes. Os votos proferidos contrariamente à maioria, por outro lado, devem eximir o autor de responsabilidade, uma vez que diminuiriam o risco, não podendo por isso, fundamentar a imputação do resultado ${ }^{287}$.

\subsubsection{Responsabilidade subjetiva na seara empresarial}

Ao falar-se em responsabilidade penal subjetiva na seara empresarial, podem ser encontradas duas situações distintas que devem ser enfrentadas de formas diversas: sociedades empresárias de estrutura menos complexa e sociedades empresárias de estrutura mais complexa.

As sociedades empresárias de estrutura menos complexa são aquelas que apresentam em sua composição um número reduzido de pessoas com funções, atribuições e competências nem sempre bem definidas, mas que, apesar disso, consegue-se apurar e aferir, com precisão, quem é a pessoa (ou pessoas) que detém a capacidade de tomada de decisão nos diversos estágios de fabricação e comercialização de produtos, bem como, a quem compete tomar qualquer decisão final. Neste sentido, podemos citar as chamadas sociedades empresárias familiares, ou aquelas de micro e pequeno porte.

\footnotetext{
${ }^{287}$ VOGEL, Joachim. op. cit., p. 101.
} 
As sociedades empresárias de estrutura mais complexa, por outro lado, são aquelas cuja estrutura é composta por um grande número de indivíduos e que, por isso mesmo, deveriam apresentar funções, atribuições e competências bem definidas, embora nem sempre o façam. Há, no entanto, a previsão legal de competências de cada uma das esferas de poder e responsabilidade em seu âmbito, assim como, (ao menos deveria haver) a definição estatutária de atribuições de cada um daqueles que ali atuam.

Para resolver os casos de imputação de responsabilidade penal pelo produto fabricado ou comercializado por sociedade de estrutura simples, pode-se recorrer aos métodos tradicionais de imputação de responsabilidade, por intermédio de simples investigação por meio da qual se chegue ao conhecimento de quem (uma ou mais pessoas, em um ou mais de um estágio de responsabilidade) partiu a decisão que causou o defeito no referido produto, ou seja, a quem, subjetivamente, ou seja, em consequência de conduta própria, dolosa ou culposa, pode ser imputada a criação do risco juridicamente proibido.

Para ilustrar, pode-se utilizar como exemplo o caso da morte de um bebê em decorrência de defeito existente em berço produzido pela sociedade empresária " $X$ ", estabelecida na forma de sociedade limitada ${ }^{288}$, fabricante de móveis para quartos de criança, que fabrica, dentre outros produtos, berços para serem utilizados por bebês de zero a trinta e seis meses ${ }^{289}$.

Na estrutura da empresa " $X$ " atuam quinze pessoas, sendo: um diretor geral, com formação em administração de empresas e economia, responsável pelas decisões finais da sociedade; três técnicos, designers de móveis, regularmente habilitados, com registro no Conselho Regional de Engenharia, Arquitetura e Agronomia, CREA, responsáveis pela concepção de todos os produtos lá fabricados, bem como, pela elaboração das instruções de montagem e recomendações de uso; um técnico, supervisor de produção, engenheiro, regularmente habilitado, com registro no CREA, responsável pelo controle da produção e

\footnotetext{
${ }^{288}$ As regras empresariais legalmente estabelecidas para o tratamento da Sociedade Limitada encontram-se, via de regra, no Código Civil, Título II (Da Sociedade), Subtítulo II (Da Sociedade Personificada), Capítulo IV (Da Sociedade Limitada) e não são objeto do presente trabalho, tendo sido suscitada apenas para esclarecer a diferença entre esta forma, menos complexa de organização em comparação àquela estabelecida como Sociedade Limitada, que será, adiante, analisada.

${ }^{289}$ Embora este exemplo seja fictício, é baseado no caso dos berços "Heritage Collection 3-in-1 drop-side cribs" do qual foram vendidas trinta e quatro mil unidades ao preço de US\$130,00 cujos defeitos causaram lesões em bebês. Imposta ressaltar que berços das mais diversas procedências costumam figurar como um dos mais perigosos produtos comercializados no "mercado de consumo norte-americano. A United States Consumer Product Safety Commission relata que desde 2007 mais de onze milhões de berços já forma alvos de recall. Em janeiro de 2011, vinte modelos de berços constavam da lista de recall da referida Comissão. Informação em US CONSUMER PRODUCT SAFETY COMMISSION. Crib Information Center. Disponível em: <http://www.cpsc.gov/info/cribs/index.html>. Acesso em: 01 jan. 2010.
} 
da qualidade dos produtos; dez operários-marceneiros, responsáveis pela fabricação dos móveis, propriamente dita.

A causa mortis, pericialmente atestada após realização de exame necroscópico, foi declara como fratura no crânio causada pela queda do estrado do berço no qual se localizava o colchão onde o bebê dormia, em decorrência do rompimento de sua estrutura de sustentação. A responsabilidade penal, neste caso, pode ou não estar presente - em um ou mais de um setor da estrutura empresária - dependendo, sua existência, de múltiplos fatores que deverão ser investigados e aferidos.

Deve-se examinar, inicialmente, o projeto do berço, isto é, se há, na concepção do produto, o planejamento para que nele se apresente a segurança legitimamente esperada pelo consumidor para aquele tipo de produto, especificamente, no que diz respeito à estrutura de sustentação. Nesta etapa, dentre outros fatores, verificam-se: a qualidade geral do produto e específica de cada um de seus componentes, daí incluídos os materiais planejados para serem utilizados em sua fabricação; se foram seguidas as recomendações do Manual de Boas Práticas de Fabricações de móveis; se foram adequadamente observados os dados técnicos e ergonômicos; se foram elaboradas as instruções de montagem de forma suficientemente clara e precisa para afastar periculosidade daí decorrentes.

Se todas as regras de segurança tiverem sido seguidas e previstas no projeto, ou seja, se a concepção do produto previr somente aqueles riscos legitimamente esperados para seu regular uso, não há que se falar em responsabilidade penal dos três designers, responsáveis pela concepção do projeto do berço. Caso contrário, deve-se continuar a investigação para que seja estabelecido qual defeito de concepção o berço apresentou e a qual dos três técnicos cabia a sua evitação, se é que isso seria possível, de acordo com o estágio de desenvolvimento científico no momento da elaboração do projeto. Deve-se, ainda, posteriormente, verificar se houve a presença de culpa, por inobservância de dever objetivo de cuidado ou, até mesmo, de dolo. A presença do dolo, em geral, é eventual, mas, nada impede que haja a presença de dolo direto. Havendo a presença de dolo ou culpa, deve o técnico responder pelo resultado morte.

Quando, após a análise do projeto, percebe-se que há defeito, mas que este não decorre da concepção do produto, uma vez que ele é projetado de forma segura e dentro dos parâmetros de risco permitido, deve-se investigar a procedência do problema, até para que não sejam mais produzidos berços ou, quaisquer outros produtos, com defeitos a este 
semelhantes. É, deste modo, necessário que, a seguir, sejam pesquisadas as etapas de fabricação do produto.

Há, também, uma série de defeitos que podem, no momento da fabricação, ser agregados a um produto que tenha um projeto isento de riscos proibidos. Ainda utilizando o exemplo do berço, há na estrutura da empresa um técnico responsável pelo controle da produção e da qualidade dos produtos, que é quem deve estabelecer como se dará a metodologia da produção, bem como, verificar a eventualidade da ocorrência de um problema em seu processo, sendo, portanto, o responsável por, neste caso, interrompê-lo e reajustá-lo aos padrões de qualidade e segurança. Este técnico pode agir dolosa ou culposamente para o resultado. Por exemplo: culposamente, por ser imperito na execução de sua função, gerando um defeito causado por equívoco na linha de produção do berço, fato que causará o mesmo defeito em todos os berços produzidos até que se perceba o problema e este seja sanado; culposamente, por ter sido negligente e deixado de proceder a um dos critérios estabelecidos para a verificação do controle de qualidade; dolosamente, ao utilizar matéria-prima de qualidade inferior, diversa da prevista no projeto, como consequência de acordo firmado com fornecedor para que recebesse uma participação percentual no valor da venda, fato que acabou por gerar um defeito de qualidade por insegurança.

Importa ressaltar que nem todos os defeitos decorrentes da fase de fabricação do produto, porém, podem ser penalmente imputados a quem quer que seja, pois alguns deles são inevitáveis, ainda que seguidas fielmente todas as regras de segurança previstas em leis, diretrizes, protocolos ou manuais de boas práticas. Ou seja, quando há o cumprimento de todas as normas de segurança, ainda que surjam defeitos nos produtos causados no momento de sua produção, os resultados deles decorrentes não podem ser penalmente imputados a ninguém, restando a tutela civil para reparação de eventuais danos. Na indústria de bebidas e alimentos, por exemplo, ainda que sejam tomadas todas as providências para que sejam corridos apenas os riscos permitidos, com o cumprimento de todas as normas existentes para tais produções, uma vez que tratam-se de produtos perecíveis, eventualmente, podem se tornar impróprios ao consumo humano, por causa de motivos, até então, cientificamente desconhecidos ${ }^{290}$. Nestes casos, por óbvio, a responsabilidade penal deve ser afastada sob pena de ser objetivamente imputada.

\footnotetext{
${ }^{290}$ Como ocorreu no caso da indústria Vonpar, responsável pela produção dos refrigerantes da marca Cocacola onde foram encontradas três unidades do referido produto com mofo, no meio de um depósito contendo mais de duzentas e trinta mil unidades. Os diretores da empresa foram equivocadamente denunciados pelo Ministério Público, numa tentativa de imputar-lhes objetivamente a responsabilidade penal.
} 
Menos grave seria o defeito de fabricação causado por um operário-marceneiro, uma vez que por sua esfera de atuação na linha produtiva ser limitada, não tem como alcançar todas as unidades produzidas, mas apenas aquelas que fossem de sua responsabilidade. Neste caso, também, o resultado morte poderia ser-lhe imputado a título de culpa ou de dolo direto ou eventual. Se, ao produzir o berço o operário tiver deixado de observar algum dever de cuidado ou, ainda, se tiver deliberadamente agido de modo a produzir o defeito, por exemplo.

Em relação à conduta e consequente responsabilidade do Diretor da sociedade empresária do exemplo em questão, deve-se considerar, inicialmente, ser ele administrador de empresas e economista. Uma vez que não é perito em produção moveleira decidiu contratar empregados legal e especificamente habilitados para exercerem as funções de planejamento e supervisão, sendo todos os técnicos regularmente inscritos no CREA. Deste modo, procurou garantir a qualidade e a segurança de sua produção. Não pode ele, portanto, arcar penalmente com as consequências das condutas de seus técnicos que já que a responsabilidade penal é sempre subjetiva. Isso só ocorreria se ele, no exercício da gestão empresarial tivesse decidido de modo perigoso e irresponsável que acabasse por colocar o consumidor final em risco além de sua legítima expectativa. No caso, por exemplo, dos importadores espanhóis de óleo de colza ${ }^{291}$, os diretores das sociedades empresárias decidiram, por razões econômicas, disponibilizar ao consumo humano óleo destinado à indústria, causando a morte e lesão à saúde em um grande número de pessoas. Seria impensável e nada técnico entender esta conduta - ou seja, a decisão livre e consciente de destinar óleo industrial, no caso, contendo anilina tóxica, à produção de alimentos - como atípica.

A estrutura empresarial menos complexa, portanto, não apresenta maiores dificuldades para a aplicação das construções típicas do Direito Penal. Os casos decorrentes de sociedades de estrutura mais complexa, no entanto, demandam maior elaboração, pois comportam cadeias de poder e divisão hierárquica de funções, competências e atribuições que podem, a um olhar menos atento, parecer impenetráveis e indecifráveis. Ocorre que, toda estrutura empresarial, por maior que seja sua complexidade, tem (ou ao menos, deveria ter) a divisão de responsabilidades bastante bem definida. A partir desta ideia, procura-se encontrar o responsável pelo resultado criminoso, tendo como baliza constante a vedação à responsabilidade penal objetiva que, nesta seara,

\footnotetext{
${ }^{291}$ Este caso está relatado em detalhes no último capítulo do trabalho.
} 
poderia ser entendida por alguns equivocados como o melhor, ou pelo menos, mais fácil, caminho.

É importante, neste ponto, que sejam ressaltados alguns aspectos.

No ordenamento jurídico brasileiro, a Lei no 6.404 de 15 de dezembro de 1976, a chamada Lei das Sociedades Anônimas, delimita as esferas de competência de cada ator presente em uma cadeia empresarial mais complexa ${ }^{292}$, tendo sido, por esta razão, utilizada para estabelecer parâmetros iniciais de aferição da responsabilidade penal de cada um dos integrantes da referida estrutura empresária. A seguir, será analisada a possibilidade de responsabilidade penal subjetiva em cada esfera de competência no cerne da sociedade empresária.

\subsubsection{A responsabilidade penal dos membros da estrutura orgânica da sociedade empresária}

Uma sociedade empresária de estrutura mais complexa, como as sociedades anônimas, por exemplo, é dividida em diversos órgãos ${ }^{293}$. FÁBIO ULHOA COELHO assevera ser importante esta divisão para atender finalidades administrativas e jurídicas, sendo, as primeiras, relacionada "à adequada divisão de trabalho, à racionalidade do fluxo de informações, à agilidade do processo decisório", dentre outras; e as últimas relativas "ao atendimento de formalidades ligadas à validade ou eficácia de atos da sociedade, dos agentes que nela trabalham, dos acionistas etc" ${ }^{\text {294 }}$. É interessante notar, no entanto, que ao Direito, em especial no que se refere ao tema aqui tratado, também interessam a divisão do trabalho, o fluxo de informações e o processo decisório como um todo.

\footnotetext{
${ }^{292}$ Ao falar-se em competências faz-se referência a esferas de responsabilidades legalmente determinadas a alguém. De outro modo, com o termo atribuições está se falando em esferas de responsabilidades delegadas a alguém por meio de estatuto.

${ }^{293}$ De acordo com Fábio Ulhoa Coelho, "A sociedade anônima se desdobra em órgãos, tais como a diretoria, conselhos, chefias, coordenadorias e outros" mas, "a organização da estrutura administrativa adotada pelas companhias abaixo do nível da diretoria (coordenadorias, superintendências, departamentos, chefias etc) é assunto irrelevante para o direito societário". COELHO, Fábio Ulhoa. Curso de direito comercial: direito de empresa. 3. ed. São Paulo: Ed. Saraiva, 1999. v. 2, p. 193. Para o Direito Penal, ao contrário, pode ser importante cada um dos possíveis níveis administrativos, no entanto, é impossível tratar de todos eles, até porque as sociedades empresárias que adotam a forma de sociedade anônima têm a liberdade de se estruturarem como quiserem, sendo obrigatórias apenas as presenças do Conselho de Administração, Diretoria, Assembleias Gerias e Conselho Fiscal .

${ }^{294}$ COELHO, Fábio Ulhoa. Curso de direito comercial: direito de empresa, cit., v. 2, p. 193.
} 
De acordo com o previsto na Lei $\mathrm{n}^{\circ}$. 6.404/76, a estrutura administrativa da sociedade empresaria, neste caso, é composta, obrigatoriamente, pelos seguintes órgãos: Conselho de Administração, Diretoria, Assembleias Gerais e Conselho Fiscal. Todos eles merecem uma análise distinta quanto à possível imputação de responsabilidade penal subjetiva a um ou mais de seus integrantes.

Ainda que uma análise a respeito da responsabilidade penal pelo produto na Sociedade Anônima mereça um trabalho mais acurado, sendo necessária a realização de pesquisa específica para que seja aprofundada a questão, procurou-se, apenas, lançar um embrião opinativo acerca do tema, uma vez que restou clara a diferença entre o tratamento que deve ser dado às empresas com diferentes complexidades estruturais.

Serão analisados, a seguir, cada um dos órgãos legalmente previstos como integrantes da estrutura das sociedades anônimas, mas somente naquilo que diz respeito ao tema aqui tratado, ou seja, naquilo que pode se relacionar com a esfera pessoal de responsabilidade, considerada a possibilidade efetiva de atuação do agente, bem como, sua capacidade de tomada de decisão na cadeia empresarial.

\section{a) Assembleia Geral e Conselho de Administração}

Trata-se de órgão deliberativo com a maior capacidade de decisão dentro da estrutura empresarial da sociedade anônima, já que tem, conforme o artigo 121 da Lei das Sociedades Anônimas, poderes para decidir todos os negócios relativos ao objeto da companhia e tomar as resoluções que julgar convenientes à sua defesa e desenvolvimento. No Brasil, é competente, conforme Fábio Ulhoa Coelho, "para apreciar qualquer assunto de interesse social, mesmo os relacionados à gestão de negócios específicos" ${ }^{295}$.

É à Assembleia Geral que compete a reforma do estatuto social (art. 122, I), bem como, a eleição ou destituição, a qualquer tempo, dos administradores e fiscais da companhia, com a exceção dos diretores que só são eleitos por ela se não houver um Conselho de Administração (art. 142, II). A Assembleia Geral é convocada pelo Conselho

\footnotetext{
${ }^{295}$ COELHO, Fábio Ulhoa. Curso de direito comercial: direito de empresa, cit., v. 2, p. 197.
} 
de Administração ou aos diretores, conforme previsão estatutária, pelo Conselho Fiscal ou pelos acionistas, observadas as condições legais específicas ${ }^{296}$.

Suas deliberações, via de regra, são tomadas por maioria absoluta dos votos dos $\operatorname{acionistas}^{297}$, não sendo computados os votos em branco (art. 129). Cabe ao estatuto, em caso de empate, estabelecer o procedimento para arbitragem. Se não houver previsão estatutária, no entanto, deverá haver nova convocação após dois meses, no mínimo e, se os votos permanecerem empatados, caberá ao Poder Judiciário decidir, no interesse da companhia. (art. 129, § $2^{\circ}$ ). As decisões deverão constar em ata assinada pelos membros da mesa e pelos acionistas presentes, sendo imprescindível à sua validação a assinatura da maioria necessária às deliberações tomadas (art. 130).

Há diversas formas de controle sobre a sociedade empresária que delimitam a relevância do órgão em análise. Importam ao presente tema a análise de três delas: totalitária, majoritária e minoritária ${ }^{298}$. Na totalitária, a assembleia geral é mero instrumento de formalização da vontade de uma pessoa que detém todas ou quase todas as ações votantes da sociedade. Não há, por isso, qualquer tipo de debate acerca dos temas a serem decididos, podendo, eventualmente, comparecer algum acionista votante minoritário em busca de esclarecimentos, mas sem capacidade alguma de tomada de decisão naquele cenário. A majoritária, por sua vez, é a forma de controle em que o acionista controlador detém a maioria das ações votantes, sendo possível aos acionistas minoritários, no entanto, titularizar ações o bastante para exercerem determinadas faculdades. Sendo assim, não se trata de instrumento de formalização da vontade de apenas um acionista, podendo, inclusive, haver debates e discordâncias entre o controlador e os minoritários durante sua ocorrência. Por último, a forma de controle minoritária é aquela em que o acionista controlador não possui a maioria das ações votantes. É indispensável a formalização legal de todos os atos ocorridos, para garantir os direitos dos acionistas. Esta é a única forma de

\footnotetext{
${ }^{296}$ Lei n ${ }^{\circ}$ 6.404: art. 123. Compete ao conselho de administração, se houver, ou aos diretores, observado o disposto no estatuto, convocar a assembléia-geral. Parágrafo único. A assembléia-geral pode também ser convocada: a) pelo conselho fiscal, nos casos previstos no número $\mathrm{V}$, do artigo 163; b) por qualquer acionista, quando os administradores retardarem, por mais de 60 (sessenta) dias, a convocação nos casos previstos em lei ou no estatuto; c) por acionistas que representem cinco por cento, no mínimo, do capital social, quando os administradores não atenderem, no prazo de oito dias, a pedido de convocação que apresentarem, devidamente fundamentado, com indicação das matérias a serem tratadas; d) por acionistas que representem cinco por cento, no mínimo, do capital votante, ou cinco por cento, no mínimo, dos acionistas sem direito a voto, quando os administradores não atenderem, no prazo de oito dias, a pedido de convocação de assembléia para instalação do conselho fiscal.

${ }^{297}$ A Assembleia Geral é composta por acionistas ou seus procuradores ou representantes legais que devem assinar um Livro de Presença, bem como especificar e classificar as ações que titularizam, antes da abertura da Assembleia Geral.

${ }^{298}$ COELHO, Fábio Ulhoa. Curso de direito comercial: direito de empresa, cit., v. 2, p. 198.
} 
controle em que o controlador não tem estabilidade em seu posto de comando. Há efetiva disputa pelo controle da sociedade empresária durante a sessão da assembleia e, segundo Fábio Ulhoa Coelho, "os blocos de acionistas se organizam, medem forças e lutam pela supremacia na condução dos negócios sociais" ${ }^{299}$.

O Conselho de Administração, por sua vez, é órgão de deliberação e fiscalização colegiado, composto exclusivamente por acionistas ${ }^{300}$, tem como função agilizar o processo decisório na sociedade empresária ${ }^{301}$. É obrigatório nas sociedades anônimas de capital aberto e nas de capital autorizado, sendo, nas demais, facultativo (art. $138 \S 2^{\circ}$ da Lei $n^{\circ}$. 6.404/76). É a este órgão, em concurso com a Diretoria, que compete a administração da sociedade empresária (art. 138, caput). Há temas, no entanto, que, devido à sua grande relevância, devem ser tratados e decididos pelas pessoas que assumiram o risco da atividade empresarial, sendo delas a responsabilidade pelas decisões, neste sentido, tomadas.

É composto por pelo menos três membros, apenas pessoas naturais, eleitos e podendo ser destituídos a qualquer tempo pela Assembleia Geral.

É competente para decidir acerca de qualquer matéria de interesse da sociedade, com exceção daquelas de competência privativa da Assembleia Geral (art. 122). Naquilo que interessa ao tema do presente trabalho, em especial, naquilo que diz respeito ao processo de tomada de decisão, cabe ao Conselho de Administração (art. 142): (I) fixar a orientação geral dos negócios da companhia; (II) eleger e destituir os diretores da companhia e fixar-lhes as atribuições, observado o que a respeito dispuser o estatuto; (III) fiscalizar a gestão dos diretores, examinar, a qualquer tempo, os livros e papéis da companhia, solicitar informações sobre contratos celebrados ou em via de celebração, e quaisquer outros atos.

\footnotetext{
${ }^{299}$ COELHO, Fábio Ulhoa. Curso de direito comercial: direito de empresa, cit., v. 2, p. 198.

${ }^{300}$ A Lei $n^{\circ}$. 6.404/76 trata das especificidades da composição do referido órgão em seu art. 140: O conselho de administração será composto por, no mínimo, 3 (três) membros, eleitos pela assembléia-geral e por ela destituíveis a qualquer tempo, devendo o estatuto estabelecer: I - o número de conselheiros, ou o máximo e mínimo permitidos, e o processo de escolha e substituição do presidente do conselho pela assembléia ou pelo próprio conselho; II - o modo de substituição dos conselheiros; III - o prazo de gestão, que não poderá ser superior a 3 (três) anos, permitida a reeleição; IV - as normas sobre convocação, instalação e funcionamento do conselho, que deliberará por maioria de votos, podendo o estatuto estabelecer quorum qualificado para certas deliberações, desde que especifique as matérias. Parágrafo único. O estatuto poderá prever a participação no conselho de representantes dos empregados, escolhidos pelo voto destes, em eleição direta, organizada pela empresa, em conjunto com as entidades sindicais que os representem.

${ }^{301}$ COELHO, Fábio Ulhoa. Curso de direito comercial: direito de empresa, cit., v. 2, p. 216.
} 
Tendo a Assembleia Geral e o Conselho de Administração poderes para decidir sobre os negócios relativos ao objeto da companhia e tomar as resoluções que julgar convenientes à sua defesa e desenvolvimento, mesmo aqueles relacionados à gestão de negócios específicos, seus membros poderão, sim, vir a ser penalmente responsabilizados.

Evidentemente, isso só irá acontecer no que diz respeito à colocação de produtos defeituosos no mercado de consumo, em casos bastante pontuais, quando, por exemplo, forem levados ao conhecimento dos referidos órgãos as características de determinado produto defeituoso e a ela houver votado por sua colocação ou manutenção no mercado por questões econômicas.

\section{b) Diretoria}

A Diretoria de uma sociedade anônima é seu órgão executivo, composto por pelo menos dois diretores, residentes no país, acionistas ou não (art. 146), que devem ser eleitos e destituíveis pelo Conselho de Administração ou pela Assembleia Geral ${ }^{302}$, devendo o estatuto da companhia estabelecer, conforme o art. 143 da Lei Lei $n^{\circ}$. 6.404/76, dentre outras situações: (IV) as atribuições e poderes de cada diretor; $\left(\S 2^{\circ}\right)$ que determinadas decisões, de competência dos diretores, sejam tomadas em reunião da diretoria.

Segundo Fábio Ulhoa Coelho, “compete aos seus membros, no plano interno, gerir a empresa, e, no plano externo, manifestar a vontade da pessoa jurídica, na generalidade dos atos e negócios que ela pratica" ${ }^{303}$. Os Diretores devem, no exercício de sua função, observar os deveres de diligência, de lealdade e de informar. O dever de diligência é aquele segundo o qual o diretor deve empregar no exercício de suas funções, o cuidado e diligência que todo homem ativo e probo costuma empregar na administração dos seus próprios negócios (Lei $\mathrm{n}^{\mathrm{o}}$. 6.404/76, art. $153 \mathrm{c} / \mathrm{c}$ art. 145) ${ }^{304}$. O artigo 154 determina

\footnotetext{
${ }^{302}$ Lei no . 6.404/76, art. 143: A Diretoria será composta por 2 (dois) ou mais diretores, eleitos e destituíveis a qualquer tempo pelo conselho de administração, ou, se inexistente, pela assembléia-geral, devendo o estatuto estabelecer: I - o número de diretores, ou o máximo e o mínimo permitidos; II - o modo de sua substituição; III - o prazo de gestão, que não será superior a 3 (três) anos, permitida a reeleição; IV - as atribuições e poderes de cada diretor. $\S 1^{\circ}$ Os membros do conselho de administração, até o máximo de 1/3 (um terço), poderão ser eleitos para cargos de diretores. $\S 2^{\circ} \mathrm{O}$ estatuto pode estabelecer que determinadas decisões, de competência dos diretores, sejam tomadas em reunião da diretoria

${ }^{303}$ COELHO, Fábio Ulhoa. Curso de direito comercial: direito de empresa, cit., v. 2, p. 229.

${ }^{304}$ Art. 145. As normas relativas a requisitos, impedimentos, investidura, remuneração, deveres e responsabilidade dos administradores aplicam-se a conselheiros e diretores. Art. 153. O administrador da
} 
importante limite a ser observado na gestão dos fins e interesses da companhia: a satisfação das exigências do bem público, bem como, da função social da empresa. Conforme o dever de lealdade, o Diretor deve manter reserva quanto aos negócios da companhia (art. 155), sendo este dever referente às informações privilegiadas que eventualmente venha a ter acesso e possa interferir no mercado de valores mobiliários. Por último, de acordo com o dever de informar, o Diretor é obrigado, por força do art. $157 \S 1^{\circ}$ a revelar à assembléiageral ordinária, a pedido de acionistas que representem $5 \%$ (cinco por cento) ou mais do capital social, dentre outros, quaisquer atos ou fatos relevantes nas atividades da companhia (art. 157, $\S 1^{\circ}$, alínea e).

Importa ressaltar que o Diretor responde civilmente por prejuízos causados à sociedade quando houver procedido (I) dentro de suas atribuições ou poderes, com culpa ou dolo e, ainda, (II) com violação da lei ou do estatuto (art. 158). A responsabilidade, aqui, é subjetiva, não podendo ser a ele imputada por atos de outros diretores ou administradores, a não ser, se com eles for conivente, se negligenciar em descobri-los ou se, deles tendo conhecimento, deixar de agir para impedir a sua prática ( $\S 1^{\circ}$, parte inicial). Porém, é eximida a responsabilidade do diretor ou administrador dissidente que fizer consignar sua divergência em ata de reunião do órgão de administração ou, não sendo possível, dela dê ciência imediata e por escrito ao órgão da administração, no conselho fiscal, se em funcionamento, ou à assembléia-geral $\left(\S 1^{\circ}\right.$, in fine $)$.

A companhia pode, inclusive, mover contra ele ação de responsabilidade civil pelos prejuízos causados ao seu patrimônio, mediante prévia deliberação da assembléia-geral (art. 159). Sua responsabilidade será excluída se o juiz se convencer que agiu de boa-fé, visando ao interesse da companhia. $\left(\S 6^{\circ}\right)$

Tendo em vista diversas regras que determinam os deveres dos membros da diretoria da empresa, dentre os quais, limite imposto pelo art. 154 da Lei das S.A., que determina que no exercício do dever de diligência sejam satisfeitas as exigências do bem público, bem como, da função social da empresa, pode-se entender que dentre os deveres impostos aos membros da diretoria de empresa responsável pela produção ou comercialização de produtos, está o cuidado devido para que sejam disponibilizados ao mercado apenas produtos que atendam as exigências do art. $6^{\circ}$ do $\mathrm{CDC}$, que elenca os direitos dos consumidores, dentre os quais o direito previsto no inciso I, à proteção da vida, 
saúde e segurança contra os riscos provocados por práticas no fornecimento de produtos considerados perigosos ou nocivos, se destaca. Sendo assim, a qualquer diretor que tenha a atribuição estatutária verificar a referida segurança, pode ser imputada a responsabilidade penal em caso de tomada de decisão que importe na colocação ou manutenção no mercado de consumo de produto potencialmente lesivo à segurança do consumidor.

\section{c) Conselho Fiscal}

O Conselho Fiscal, instrumento de fiscalização da gestão empresarial legalmente conferido aos acionistas ${ }^{305}$, assessora a Assembleia Geral e é órgão obrigatório, cabendo ao estatuto dispor a respeito de seu funcionamento permanente ou não (art. 161). É composto por três a cinco membros - pessoas naturais, residentes no País, diplomadas em curso de nível universitário, ou que tenham exercido por prazo mínimo de três anos, cargo de administrador de empresa ou de conselheiro fiscal, a menos que não haja um número suficiente de pessoas habilitadas na localidade da companhia, caso em que caberá ao juiz dispensar a satisfação de tais requisitos (art. 162, caput $\S 1^{\circ}$ ) e - acionistas ou não, e suplentes no mesmo número, eleitos pela Assembleia Geral $\left(\S 1^{\circ}\right)^{306}$. Dentre as funções de competência do conselho fiscal previstas no art. 163, importam ao presente tema, no que diz respeito à capacidade de tomada de decisão: I - fiscalizar, por qualquer de seus membros, os atos dos administradores e verificar o cumprimento dos seus deveres legais e estatutários; II - opinar sobre o relatório anual da administração, fazendo constar do seu parecer as informações complementares que julgar necessárias ou úteis à deliberação da assembléia-geral; IV - denunciar, por qualquer de seus membros, aos órgãos de administração e, se estes não tomarem as providências necessárias para a proteção dos interesses da companhia, à assembléia-geral, os erros, fraudes ou crimes que descobrirem, e sugerir providências úteis à companhia (art. 163). Pode, ainda para apurar fato cujo esclarecimento seja necessário ao desempenho de suas funções, formular, com justificativa, questões a serem respondidas por perito e solicitar à diretoria que indique,

\footnotetext{
${ }^{305}$ COELHO, Fábio Ulhoa. Curso de direito comercial: direito de empresa, cit., v. 2, p. 230.

${ }^{306}$ Art. $161 \S 4^{\text {o }} \mathrm{Na}$ constituição do conselho fiscal serão observadas as seguintes normas: a) os titulares de ações preferenciais sem direito a voto, ou com voto restrito, terão direito de eleger, em votação em separado, 1 (um) membro e respectivo suplente; igual direito terão os acionistas minoritários, desde que representem, em conjunto, $10 \%$ (dez por cento) ou mais das ações com direito a voto; b) ressalvado o disposto na alínea anterior, os demais acionistas com direito a voto poderão eleger os membros efetivos e suplentes que, em qualquer caso, serão em número igual ao dos eleitos nos termos da alínea a, mais um
} 
para esse fim, no prazo máximo de trinta dias, três peritos, que podem ser pessoas físicas ou jurídicas, de notório conhecimento na área em questão, entre os quais o conselho fiscal escolherá um, cujos honorários serão pagos pela companhia $\left(\S 8^{\circ}\right)$. Importa esclarecer que a função de seus membros é indelegável $\left(\$ 7^{\circ}\right)$.

Os membros do Conselho Fiscal possuem os mesmos deveres dos diretores naquilo que diz respeito ao dever de diligência, de informação e lealdade e respondem pelos danos resultantes de omissão no cumprimento de seus deveres e de atos praticados com culpa ou dolo, ou com violação da lei ou do estatuto, conforme art. 165, não sendo, no entanto responsável pelos atos ilícitos de outros membros, salvo se com eles foi conivente, ou se concorrer para a prática do ato $\left(\S 2^{\circ}\right)$. A responsabilidade civil por omissão no cumprimento de seus deveres é solidária, podendo dela se eximir o membro dissidente que fizer consignar sua divergência em ata da reunião do órgão e a comunicar aos órgãos da administração e à assembléia-geral $\left(\S 3^{\circ}\right)$.

Uma vez que possuem os mesmos deveres dos membros da Diretoria da empresa no que diz respeito ao cumprimento dos deveres de diligência, caberão aos membros do Conselho Fiscal as mesmas possibilidades de responsabilização penal, sendo claro que, só será cogitada esta imputação, tendo-se em vista a esfera de efetiva responsabilidade e real possibilidade de atuação do Conselho diante da colocação de produtos no mercado de consumo, dependendo, portanto, de determinações estatutárias.

Importa ressaltar que os referidos membros da estrutura orgânica da empresa podem vir a ser responsabilizados por conduta comissiva ou omissiva, dolosa ou culposa.

A decisão pela colocação do produto no mercado de consumo é conduta comissiva ao passo que a decisão pelo não cumprimento do dever de retirada importa em decisão em se omitir diante do perigo anteriormente causado pela atividade empresarial.

A modalidade culposa, ou seja, aquela que segundo o Código Penal é praticada quando o agente deu causa ao resultado por imprudência, negligência ou imperícia, pode ser verificada em qualquer caso de descumprimento de dever objetivo de cuidado, seja de um membro da diretoria da empresa que deixa de se informar adequadamente a respeito das características de um produto pelo qual seja responsável; seja de um técnico, um engenheiro, por exemplo, que falhou nos cálculos estruturais necessários à sustentação de um edifício. 
Para o Código Penal brasileiro, art. 18, I, é dolosa a conduta quando o agente quis o resultado ou assumiu o risco de produzi-lo. Nos casos de responsabilidade penal pelo produto não são comuns os casos de dolo direto, sendo mais comum é a atribuição do dolo a título de dolo eventual, ou seja, não em decorrência da vontade do agente produzir um resultado, mas como consequência de ter assumido o risco de sua produção. Isso ocorre, por exemplo, nos casos em que sabendo do potencial lesivo de determinado produto, se opta por mantê-lo ou introduzi-lo no mercado de consumo, por exemplo, nos casos em que a decisão pela retirada importasse em grave prejuízo econômico.

Fundamental é que se estabeleça que a responsabilidade penal na esfera da empresa é essencial à tutela da sociedade tendo-se em vista o enorme potencial lesivo que pode ser imposto ao consumidor no caso de descumprimento dos direitos que ele tem de proteção da vida, saúde e segurança contra os riscos provocados por práticas no fornecimento de produtos considerados perigosos ou nocivos.

\subsubsection{A responsabilidade penal dos técnicos e peritos}

As normas referentes à responsabilidade dos administradores constantes da Lei das Sociedades Anônimas, aplicam-se, não apenas aos Diretores e Conselheiros, mas, também, aos membros de quaisquer órgãos, criados pelo estatuto, com funções técnicas ou destinados a aconselhar os administradores, e acordo com seu art. 160.

Há, evidentemente, peculiaridades que devem ser observadas.

Os técnicos e peritos são profissionais que têm capacitação técnica para o exercício de função para a qual estão legalmente habilitados e na qual possuem conhecimento diferenciado.

Qualquer defeito de concepção do produto será de responsabilidade daquele que o concebeu, pelo menos, a título de culpa. Embora parte da doutrina entenda não haver a possibilidade de coautoria em crimes culposos, ESTHER DE FIGUEIREDO FERRAZ assevera que não é pelo fato de ser o crime culposo que "deixará de haver coincidência ou confluência de vontades exigida para a caracterização do concurso, embora os agentes não atuem no sentido de, intencionalmente, alcançar o resultado". Na hipótese de concepção de produtos que pode ser tarefa de responsabilidade de mais de uma pessoa, esta possibilidade 
fica clara. É importante ressalvar, no entanto, que mesmo em casos em que haja a responsabilidade conjunta pelo desenvolvimento de um produto é necessária a individualização da conduta capaz de gerar o resultado indesejado.

Nos casos em que cabe ao técnico ou perito o aconselhamento de um diretor a respeito da segurança de determinado produto, por exemplo, a sua opinião imperita levando o diretor a erro é capaz de excluir-lhe a responsabilidade, pelo menos, a título de dolo.

\subsubsection{A responsabilidade penal dos diversos empregados da sociedade empresária}

A conduta dos empregados de qualquer sociedade empresária, responsáveis por funções pontuais, fora das esferas técnica e decisória da companhia, e que não tenham capacidade de ação nem de tomada de decisão além de seu campo de atuação pessoal tem possibilidade bastante reduzida de causação de dano por intermédio da colocação de produtos defeituosos no mercado de consumo. Deste modo, as regras comumente utilizadas para a verificação de autoria e participação são suficientes para solucionar as questões que surjam neste particular.

\subsection{A responsabilidade pelo produto na União Europeia}

Tendo em vista o fato de a doutrina e a jurisprudência nacional, até o presente momento, não terem produzido material significativo sobre a responsabilidade penal pelo produto, recorreu-se à doutrina e jurisprudência da União Europeia, em especial, às alemãs e espanholas, que, apresentam casos paradigmáticos neste setor, sendo, por esta razão, constantemente, referidos no presente trabalho.

Na União Europeia, a Diretiva ${ }^{307} 85 / 374 / \mathrm{CEE}^{308}$, de 25 de Julho de 1985, procurou harmonizar, dentro do possível, as normas dos Estados-membros da União Europeia ${ }^{309}$ no

\footnotetext{
${ }^{307}$ As chamadas "diretivas", conforme o artigo 189 do Tratado de Roma (que, em 25 de março de 1957, constituiu a, então, Comunidade Econômica Europeia, hoje União Europeia), "vincula o Estado-membro destinatário quanto ao resultado a alcançar, deixando, no entanto, às instâncias nacionais a competência quanto à forma e aos meios".

${ }^{308}$ EUR-LEX. Directiva 85/374/CEE do Conselho, de 25 de Julho de 1985, relativa à aproximação das disposições legislativas, regulamentares e administrativas dos Estados-Membros em matéria de responsabilidade decorrente dos produtos defeituosos. Disponível em: <http://eurlex.europa.eu/LexUriServ/LexUriServ.do?uri=CELEX:31985L0374:pt:HTML>. Acesso em: 19 set. 2008.

${ }^{309}$ Conforme o artigo 100 do Tratado de Roma, as diretivas buscam "a aproximação das disposições legislativas, regulamentares e administrativas dos Estados-membros que tenham incidência direta no estabelecimento ou no funcionamento do mercado comum".
} 
que diz respeito à responsabilidade do produtor pelos danos causados à vida, à saúde e aos bens dos consumidores por produtos defeituosos. De acordo com seu texto, é necessária a aproximação das legislações dos Estados-membros nesta matéria, pois sua diversidade pode enganar a concorrência, prejudicar a livre circulação de mercadorias e gerar disparidades no nível de proteção oferecida ao consumidor contra danos causados a sua saúde e a seus bens por produtos defeituosos.

Ainda que a diretiva não trate de responsabilidade penal, faz-se necessário analisála para que, por um lado, possamos entender a racionalidade do legislador europeu no que concerne a proteção do consumidor e a consequente reparação de danos causados por produtos defeituosos e, por outro, pelo fato de que o Código de Defesa do Consumidor, ou seja, a lei brasileira que objetiva tutelar o consumidor no âmbito de suas relações com um fornecedor, e que dedica especial atenção à sua segurança, em diversos pontos, se inspira neste importante diploma normativo europeu.

A proteção ao consumidor frente aos danos causados por produtos defeituosos, na esfera da Diretiva, abarca as lesões à sua vida, integridade física e patrimônio. Na esfera civil $^{310}$, é atribuída ao produtor a responsabilidade objetiva ${ }^{311}$, impossível ao âmbito penal, aplicado em um Estado Democrático de Direito. Todo o ônus da prova é atribuído à vítima, daí incluídos o dano, o defeito e o nexo causal entre eles existente (art. $4^{\circ}$ ).

Conforme o artigo $1^{\circ}$, "o produtor é responsável pelo dano causado por um defeito do seu produto". O produto, no entanto, não é qualificado como "defeituoso" por ser inapto à sua regular e habitual utilização nem por ter ficado obsoleto pelo lançamento de um similar mais aperfeiçoado, mas por não oferecer a segurança que o consumidor dele legitimamente espera em suas condições regulares de uso, para o fim a que se destina (art. $6^{\circ}$ ). A diretiva entende "dano" como: morte, lesão corporal ou avaria ou destruição de uma coisa normalmente destinada a uso ou consumo privado e que tenha sido utilizada pela vítima para seu uso ou consumo privado (art. $\left.9^{\circ}\right)$.

\footnotetext{
${ }^{310} \mathrm{O}$ valor da indenização por responsabilidade civil pode ser fixado por cada Estado-Membro a um limite não inferior a 70 milhões de euros, relativo à responsabilidade global do produtor pelos "danos resultantes da morte ou de lesões corporais causados por artigos idênticos que apresentem os mesmos defeitos", conforme o artigo 16 da Diretiva em análise.

${ }^{311}$ De acordo com o Princípio da responsabilidade não culposa, estabelecido pela Diretiva, o produtor será objetivamente responsabilizado, em caso de dano causado por seu produto, ou seja, não há necessidade de o consumidor provar dolo ou culpa do produtor, sendo suficiente a prova do dano e seu nexo causal com o produto. Se houver mais de um responsável pelo dano, serão todos solidariamente responsáveis $\left(\operatorname{art} .5^{\circ}\right)$.
} 
Como responsáveis, são elencados todos os "produtores", ou seja, qualquer dos participantes do processo produtivo, daí, incluídos, o fabricante de um produto acabado; o produtor de uma matéria-prima; o fabricante de uma parte componente; aquele que se apresente como produtor "mediante a aposição do seu nome, marca ou qualquer outro sinal distintivo"; aquele que forneça um produto cujo produtor não possa ser identificado; ou "qualquer pessoa que importe um produto na Comunidade tendo em vista uma venda, locação, locação financeira ou qualquer outra forma de distribuição no âmbito da sua atividade comercial”. A vítima pode exigir indenização integral de qualquer um deles, pela aplicação do Princípio da responsabilidade solidária.

Também é elencado como potencialmente responsável, o próprio consumidor. Nesses casos, o produtor pode minorar ou, até mesmo, se isentar de responsabilidade (art. $8^{\circ}$ ). Não poderá, porém, ter sua responsabilidade reduzida ou excluída por uma cláusula contratual limitativa ou exoneratória (art. 12). O produtor poderá, ainda, se isentar de responsabilidade se provar que não colocou o produto em circulação; que o defeito é posterior à sua colocação no mercado; que o produto não foi produzido para fins comerciais ou profissionais; que o produto está em conformidade com as normas exaradas pela administração pública; que era cientificamente impossível, no momento da distribuição do produto, detectar a presença do defeito ${ }^{312}$; e, no caso de produtor de componente, que o defeito é decorrente ou da concepção do produto ao qual ele foi incorporado ou das instruções dadas por seu fabricante (art. $7^{\circ}$ ).

Segundo a diretiva, seria irracional não limitar temporalmente a responsabilidade do produtor pelos eventuais danos, pois os produtos se deterioram, as normas se tornam mais rígidas e os conhecimentos técnicos e científicos avançam ${ }^{313}$. Por isso, prevê dez anos, contados a partir da data em que o produto foi colocado em circulação no mercado, para que seja extinta a responsabilidade do produtor por ele (art. 11). É, ainda, previsto para que o consumidor reclame indenização, prazo prescricional de três anos, a contar da data em que o lesado tomou ou deveria ter tomado conhecimento do dano, do defeito e da identidade do produtor, extinguindo a responsabilidade após esse prazo, sem prejuízo das

\footnotetext{
${ }^{312}$ Os Estados-membros podem adotar normas que derroguem essa exclusão de responsabilidade.

${ }^{313}$ De acordo com a diretiva, alguns países podem entender como equivocada a postura de se exonerar a responsabilidade do produtor tendo como razão o fato de que, no momento da entrada do produto em circulação, os conhecimentos científicos e técnicos não eram capazes de apontar o defeito em questão. Nesses países, pode-se legislar no sentido de inadmitir esse argumento como prova para eximir o produtor de responsabilidade, mas que, neste caso, a nova legislação, para aumentar a uniformidade da proteção da Comunidade, deve se subordinar a um "procedimento de stand-still comunitário" (art. 15).
} 
disposições dos Estados-membros que regulam a suspensão ou a interrupção da prescrição (art. 10).

\subsection{Produto e resultado: dificuldades na verificação do curso causal}

A questão da causalidade é das mais intricadas e controvertidas na discussão da responsabilidade penal pelo produto.

Faz-se essencial, para sua constatação, a aferição de duas circunstâncias: a conduta humana, que desde a gênese do produto até sua comercialização, foi responsável pelo defeito do produto, capaz de gerar risco ou lesão à vida ou integridade física do consumidor e; a efetiva capacidade do produto de gerar, por causa dos efeitos nocivos de seus elementos, individual ou conjuntamente considerados, danos aos bens jurídicos vida e integridade física da pessoa que, por ventura venha a ter contato com ele, utilizando-o para realizar os fins a que regularmente se destina.

A fabricação e distribuição de produtos são atividades, na maioria das vezes, praticadas no âmbito empresarial se desenvolvendo, deste modo, por meio de uma cadeia de funcionários e diretores mais ou menos extensa, dependendo da complexidade da organização. Cada uma das pessoas atuantes nesta cadeia deve ter, no exercício de suas funções, a responsabilidade e a capacidade de tomada de decisão balizadas e limitadas à sua devida esfera de obrigações, ou seja, cada um tem o poder de agir na dentro das fronteiras de seu dever de atuação profissional.

Deve-se verificar, preliminarmente, se o produto é efetivamente responsável pela lesão causada ao consumidor ${ }^{314}$. Sendo confirmada esta circunstância, passa-se à próxima etapa, qual seja, apurar quem, dentro da cadeia que vai da produção à comercialização, deu origem ao defeito do referido bem. É necessário, deste modo, que seja identificado qual o comportamento deu causa ao evento para se apontar qual ou quais integrantes da empresa são responsáveis, dolosa ou culposamente, por ele.

\footnotetext{
${ }^{314}$ KUHLEN, Lothar. Cuestiones fundamentales de la responsabilidad penal por el producto. In: MIR PUIG, Santiago; LUZÓN PEÑA, Diego Manuel (Coords.). Responsabilidad penal de las empresas y sus órganos y responsabilidad por el producto. Barcelona: Bosch, 1996. p. 239.
} 
Conforme Miguel Reale Júnior:

Pelo nexo causal é estabelecido se uma determinada ação pode ser considerada causa de determinado resultado. Em outras palavras, tratase de saber da existência de um vínculo entre duas realidades, de forma a que se reconheça que um dano é consequência de uma atividade.

Para que um fato seja considerado causa de um evento, deve ser condição suficiente, total e efetivamente concorrente para a produção deste evento ${ }^{315}$. Há casos em que esta etapa é facilmente ultrapassada, por ser óbvia a ligação entre o produto e o resultado $^{316}$. Em outras palavras: a definição da causalidade pode ser, muitas vezes, facilmente estabelecida pela subsunção dos parâmetros verificados do caso concreto a uma lei geral que prediga com segurança, em razão do conhecimento científico da época, que uma condição é suficiente à produção de um resultado, ou seja, quando há um enunciado geral conforme o qual a um fato $x$ sempre se seguirá um fato $y^{317}$. Esta possibilidade, no entanto, nem sempre se dá. Como se demonstra no caso Lederspray, há situações em que não há a possibilidade de se encaixar os processos causais ocorridos no caso concreto através das leis gerais, sendo, deste modo, impossível, pelo modelo anteriormente descrito, uma vinculação causal específica daquele produto ao resultado alegado. Conforme assevera Ingeborg Puppe, para estabelecer juridicamente a relação causal entre uma conduta e um resultado pode-se socorrer das ciências naturais, mas não se pode esperar que elas ofereçam soluções prontas para todos os casos, uma vez que as ciências naturais e a ciência jurídica apresentam objetos e indagações diversas ${ }^{318}$.

Nestes casos, o Tribunal Supremo alemão, passou a adotar aquilo que parcela da doutrina chama de "causalidade plausível" 319 ou um modelo de "caixa negra" ${ }^{320}$, segundo

\footnotetext{
${ }^{315}$ PUPPE, Ingeborg. Problemas de imputación del resultado en el ámbito de la responsabilidad penal por el producto. In: MIR PUIG, S; LUZÓN PEÑA, D. M. (Coords.). Responsabilidad penal de las empresas e sus órganos y responsabilidad por el producto. Barcelona: Jose Maria Bosch Editor, 1996. (Colección Biblioteca de Derecho Penal).

${ }^{316}$ No caso da amputação de dedos pelo mecanismo de rebatimento do banco traseiro para ampliação do porta-malas do automóvel Fox, adiante relatado, a ligação causal não era colocada em dúvida. Em caso de um processo criminal, seria necessário aferir, portanto, apenas, a quem caberia a responsabilidade pelo acionamento do mecanismo.

${ }^{317}$ PUPPE, Ingeborg. El resultado y su explicación causal en derecho penal. In: SANCINETTI, Marcelo A. (Comp.). Causalidade, riesgo e imputación: 100 años de contribuiciones críticas sobre imputación objetiva y subjetiva. Buenos Aires: Hammurabi, 2009. p. 249.

${ }^{318} \mathrm{E}$ completa, Puppe: "El problema de la causalidad se plantea para el jurista de modo diferente que para el físico o el astrónomo, y lo mismo vale para el teórico de la ciencia orientado a las ciencias naturales (...) para el jurista es de decisiva importancia la cuestión de si un suceso determinado (real) deve ser incluido em la explicación causal de un resultado o no". PUPPE, Ingeborg. El resultado y su explicación causal en derecho penal, cit., p. 247.

${ }^{319}$ SOUSA, Susana Aires de. op. cit., p. 117.

${ }^{320}$ Explicada, em detalhes, adiante.
} 
o qual se conhecem os fatos anteriores a entrada na caixa negra, assim como aqueles posteriores à saída, ou seja, a consequência da passagem por ela, mas não se consegue estabelecer nem entender o que ocorreu em seu interior. A aceitação da causalidade nestes termos, em que não se consegue dar respostas precisas acerca de qual elemento específico do produto foi responsável por causar a lesão, foi suscitada no caso Contergan e adotada, no caso Lederspray, entre outros, substituindo a presença de prova pericial precisa pelo convencimento do juiz, diante de todos os elementos apresentados, da existência do nexo causal entre o uso do produto e os resultados lesivos. Embora seja inadmissível para a maioria da doutrina que o juiz possa formar sua própria opinião a respeito de uma cadeia causal quando isso não é afirmado indubitavelmente pela prova pericial trazida pela perícia $^{321}$, no caso Contergan, mesmo diante da argumentação da defesa da existência de concausas $^{322}$, ou seja, de que o medicamento havia causado lesões somente naquelas pessoas predispostas física ou psicologicamente, o Tribunal não afastou a causalidade.

Parte da doutrina discorda desta posição do Supremo Tribunal alemão por entender que se deve respeitar o critério da adequação do caso concreto, por meio de constatação pericial, à lei geral estabelecida pela ciência competente. Se não se conseguir estabelecer sequer uma lei geral, para esta parcela da doutrina, os imputados não podem ser responsabilizados ${ }^{323}$.

Estabelecido o nexo causal existente entre o produto e a lesão ao consumidor, devese aferir quem, dentro da cadeia que produz e leva o produto ao mercado de consumo, foi responsável pelo defeito a ele agregado. Note-se que a condição suficiente penalmente relevante, neste momento, é apenas a conduta humana investigada como causa. A conduta humana, porém, jamais está isolada no caso concreto, havendo, necessariamente, outros fatores a ela reunidos que contribuem para a causação do resultado. Estes fatores, diversos da conduta humana em análise, não interessam como causa penalmente relevante. Assim, ao se entender causa como a condição suficiente para a produção de um resultado, estabelece-se que a conduta humana pode ser, no máximo, uma parte da causa e nunca toda a causa $^{324}$.

\footnotetext{
${ }^{321}$ KUHLEN, Lothar. op. cit., p. 239.

${ }^{322} \mathrm{~A}$ defesa usou argumentos que iam do fato das mães terem assistido televisão excessivamente, até terem sido expostas a chuva radioativa. SARRABAYROUSE, Eugenio C. Responsabilidad penal por el producto. Buenos Aires: Ad-Hoc, 2007. p. 46.

${ }^{323}$ Id. Ibid., p. 282.

${ }^{324}$ PUPPE, Ingeborg. El resultado y su explicación causal en derecho penal, cit., p. 248.
} 
Outra questão de relevância é a dificuldade em determinar se mesmo quando não há a determinação de retirada do produto, deve ser possível a imputação de responsabilidade por omissão. Mas, se, uma vez que, com o comportamento anterior, ou seja, a colocação do produto no mercado, criou-se o risco da ocorrência do resultado, não deveria haver tal dificuldade. Pois, aqui, os responsáveis pela decisão de colocar o produto no mercado devem assumir a condição de garantidores, respeitando-se o critério da responsabilidade pela tomada de decisão. Na sentença do caso Contergan o Tribunal Supremo alemão estabeleceu como parâmetro para solucionar esta questão que diante de suspeitas certas e crescentes a respeito da provável existência de perigo do produto, cabe à empresa que a colocou no mercado um amplo dever de informar e advertir o consumidor ${ }^{325}$.

A aferição da causalidade, especialmente, quando tratamos de danos causados por pessoas que atuam ao longo da cadeia empresarial, que podem, inclusive, ter suas ações estabelecidas por decisões tomadas por meio de órgãos colegiados não é simples. A teoria da conditio sine qua non levaria, inevitavelmente, à impossibilidade de imputação de responsabilidade penal, por exemplo, nos casos em que, para a formação das decisões colegiadas não fosse necessária a unanimidade. Na Alemanha, diversas são as teorias que procuram resolver a questão da causalidade entre a conduta praticada no âmbito empresarial e o perigo ou eventual resultado lesivo dela advindo para que não haja aquilo Schünemann chamou de irresponsabilidade organizada ${ }^{326}$.

Para LUTHAR KUHLEN, independentemente de qual posição venha a ser adotada para resolver esta questão, não há qualquer impedimento para que em um Estado Democrático de Direito, aquele que tenha votado a favor de uma decisão colegiada, deva responder penalmente por suas consequências ${ }^{327}$.

Nas palavras de MIGUEL REALE JÚNIOR “A relação física de causalidade, por meio da qual se atribui a qualidade de causa de um evento à determinada ação, constitui imputatio facti, que, a nosso ver, não pode no campo penal estar totalmente desvinculada da imputatio delicti ${ }^{328}$. Concluindo, seja qual for a teoria adotada, o fundamental à

\footnotetext{
${ }^{325}$ SARRABAYROUSE, Eugenio C. op. cit., p. 49.

${ }^{326}$ Embora Schünemann utilize esta expressão para defender a responsabilidade penal da pessoa jurídica, considerando inadequada a imputação de responsabilidade individual no âmbito da empresa, sua utilidade e conveniência se dá na medida em que o objetivo de evitar que uma conduta criminosa reste sem consequências através da busca responsáveis - sejam pessoas naturais ou jurídicas - e imputação de consequências penais, é o mesmo aqui perquirido.

${ }^{327}$ KUHLEN, Lothar. op. cit., p. 241.

${ }^{328}$ REALE JÚNIOR, Miguel. Teoria do delito. São Paulo: Ed. Revista dos Tribunais, 1998. p. 137.
} 
imputação de responsabilidade é que além da conduta haja um momento psicológico ligando sua prática ao resultado.

\subsubsection{A teoria da "causalidade plausível" ou da "caixa negra"}

Em alguns casos de responsabilidade pelo produto, surge a dificuldade na verificação, por meio das ciências naturais, do nexo de causalidade entre o resultado e o uso ou consumo do produto. Essa característica se faz presente naqueles produtos onde há tamanha diversidade de elementos químicos que torna impossível a verificação de qual exato princípio ativo é responsável por causar específica lesão à saúde do consumidor. São, via de regra, medicamentos ou qualquer outro tipo de produto químico ${ }^{329}$.

A jurisprudência alemã, no caso do Lederspray, detalhado adiante, o BGH se baseou para estabelecer a relação de causalidade, no princípio da livre valoração da prova, defendendo que, desde que o juiz não tenha dúvida razoável de sua existência e que sua convicção não contrarie os conhecimentos científicos, não há a necessidade da certeza absoluta, objetiva e indubitável ${ }^{330}$. Sabia-se, por valores estatísticos e pela eliminação de outras causas possíveis, que o spray de couro era o causador do resultado lesivo à saúde dos consumidores, no entanto, com base no conhecimento científico de então, não se conseguiu apontar precisamente o elemento presente na fórmula do spray capaz de deflagrar tais lesões.

Neste mesmo sentido, caminha a jurisprudência espanhola. No caso do Óleo de Colza ocorrido, a sentença do Tribunal Supremo assevera:

“... en los nexos causales de cierta complejidad siempre existe la posibilidad de aumentar las exigencias de los presupuestos de formulación de una ley causal natural hasta límites que hagan imposible superar el non liquet. En este contexto se debe considerar que existe una ley causal natural cuando, comprobado um hecho en un número muy considerable de casos similares, sea posible descartar que el suceso haya sido producido por otras causas. Tales condiciones son suficientes para garantizar una decisión racional del caso desde el punto de vista del derecho penal...".331

\footnotetext{
${ }^{329}$ Os casos Contergan, Holzschutzmittel e Lederspray são, neste sentido, exemplares.

${ }^{330}$ VOGEL, Joachim. op. cit., p. 96.

${ }^{331}$ SARRABAYROUSE, Eugenio C. op. cit., p. 87-88.
} 
Parte da doutrina critica este modelo defendendo a ideia de que houve a modificação do conceito jurídico-material de causalidade, sendo substituída a teoria da causalidade adequada por uma teoria da causalidade plausível ${ }^{332}$, que atendendo um modelo de "caixa negra" ${ }^{333}$, acaba por admitir estatisticamente a causalidade. Segundo este modelo, conhece-se o fato de que o produto tem relação causal com os resultados lesivos, sendo, além disso, possível excluir-se quaisquer outras causas como lesivas, mas não se consegue precisar dentre os componentes do produto qual é o decisivo para o desencadeamento da causalidade ${ }^{334}$. Há críticas, ainda, no sentido de afirmar que este modelo normatiza a causalidade estendendo, deste modo, a possibilidade de imputação de responsabilidade penal para situações que esta não alcançaria se fixando à causalidade adequada.

\subsubsection{Causalidade cumulativa}

A causalidade cumulativa tem importância na análise da responsabilidade penal pelo produto, notadamente, nos casos de decisão em órgão de deliberação colegiada.

Nos órgãos colegiados as decisões são tomadas tendo em conta os votos emitidos por cada um de seus membros. A grande dúvida a respeito da responsabilidade nesse cenário diz respeito às situações em que não se faz necessária a unanimidade para formar uma decisão. Isso ocorre pois de acordo com as regras tradicionais de causalidade, os votos posteriores à formação da maioria seriam desconsiderados, uma vez que seriam indiferentes ao resultado, excluindo-se, deste modo, a responsabilidade por eles. No entanto, Supremo Tribunal alemão aceitou esta solução para o tratamento do problema em análise, posição esta que parece bastante acertada, uma vez que não seria razoável considerar a ordem cronológica da votação, mas apenas o seu resultado final.

\footnotetext{
${ }^{332}$ VOGEL, Joachim. op. cit., p. 98.

${ }^{333} \mathrm{O}$ termo "caixa negra" empregado neste sentido advém da Teoria Geral dos Sistemas, utilizado por diversas áreas do conhecimento, da Matemática à Administração de Empresas, passando pela Biologia. A "caixa negra" seria, neste sentido, um sistema no qual são consideradas apenas as circunstâncias de entrada e saída, sendo desconhecidos os cursos ocorridos em seu interior. Trata-se de uma hipótese simplificadora, que confirma a existência de um curso, apesar de desconhecer suas especificidades.

${ }^{334}$ SOUSA, Susana Aires de. op. cit., p. 117.
} 


\subsection{Causalidade no Código Penal brasileiro}

De acordo com os parâmetros estabelecidos por nosso Código Penal para o tratamento da causalidade e com os caminhos comumente percorridos, em diversas ocasiões, aquele que é responsável pela fabricação ou comercialização do produto defeituoso restará sem a possibilidade de ser criminalmente responsabilizado, em especial, nos casos referentes às empresas que depositem a capacidade de decisão em órgãos colegiados.

O Código Penal brasileiro, em seu artigo 13, adotando a teoria da equivalência das condições, determina:

O resultado, de que depende a existência do crime, somente é imputável a quem lhe deu causa. Considera-se causa a ação ou omissão sem a qual o resultado não teria ocorrido.

$\S 1^{\mathrm{o}}$ - A superveniência de causa relativamente independente exclui a imputação quando, por si só, produziu o resultado; os fatos anteriores, entretanto, imputam-se a quem os praticou.

Segundo a teoria da equivalência das condições, adotada pelo caput do artigo 13 do Código Penal, é causa aquele fato que se fosse suprimido eliminaria, também, o resultado, ou seja, é uma conditio sine qua non. Para impedir o chamado regresso ad infinitum, ou seja, a consideração de fatos remotos - que nada têm a ver com o evento - como causa, realiza-se um exame do aspecto psicológico, aferindo a presença de dolo ou culpa, elementos essenciais à responsabilidade penal.

A teoria da causalidade adequada, adotada pelo $\S 1^{\circ}$, determina como causa o antecedente que, abstratamente, conforme as leis de causalidade e os conhecimentos do agente, seja idôneo à produção do resultado ${ }^{335}$. Mas isto, avaliado posteriormente, diante de um juízo ex ante, do terceiro observador, no caso, um juiz, que deve verificar se, no momento em que se realizou a conduta era possível prever, de acordo com as leis da causalidade natural, a ocorrência do resultado.

E, no que diz respeito à omissão, prevê o mesmo artigo 13 em seu $\S 2^{\circ}$ :

\footnotetext{
${ }^{335}$ REALE JÚNIOR, Miguel. Teoria do delito, cit., p. 246.
} 
A omissão é penalmente relevante quando o omitente devia e podia agir para evitar o resultado. $O$ dever de agir incumbe a quem:

a) tenha por lei obrigação de cuidado, proteção ou vigilância;

b) de outra forma, assumiu a responsabilidade de impedir o resultado;

c) com seu comportamento anterior, criou o risco da ocorrência do resultado.

Entende-se que o art. 13, ao conceituar como causa a ação ou omissão sem a qual o resultado não teria ocorrido, não apresenta oposição à possibilidade para a aceitação da tomada de decisão, do descumprimento do dever objetivo de cuidado ou do dever de diligência na cadeia empresarial seja entendido como causa. Deste modo, aferido o resultado decorrente de uma dessas ações, estas serão entendidas como causa do resultado indesejado. Assim, aquele que toma a decisão de colocar um produto defeituoso no mercado dá causa por meio de sua decisão a eventuais resultados delituosos, bem como, aquele que deixa de observar o dever objetivo de cuidado ou de diligência. E é a eles que cabe, portanto, a imputação de responsabilidade penal.

Naquilo que se refere à omissão, por sua vez, a pessoa responsável pela colocação ou manutenção de um produto defeituoso no mercado de consumo pode ter-lhe estabelecida a causalidade entre a sua conduta e o resultado indesejado uma vez que tenha criado, dolosa ou culposamente, o risco da produção deste resultado. Para a omissão ser considerada causa, deve também ser condição necessária à produção do resultado ${ }^{336}$. Se, por exemplo, aquele que é responsável pela colocação do produto perigoso no mercado de consumo, deixar de retirá-lo, mesmo após determinação de autoridade competente ${ }^{337}$, os riscos e danos daí advindos terão ligação causal com esta omissão.

\footnotetext{
${ }^{336}$ REALE JÚNIOR, Miguel. Teoria do delito, cit., p. 257.

${ }^{337} \mathrm{O}$ artigo 64 do Código de Defesa do Consumidor, assim tipifica a conduta de "deixar de retirar do mercado, imediatamente quando determinado pela autoridade competente, os produtos nocivos ou perigosos".
} 


\section{NECESSIDADE E LIMITES A UMA RESPONSABILIDADE PENAL PELO PRODUTO. PROPOSTAS E VIAS A SEREM PERCORRIDAS}

\subsection{A deficiência do ordenamento jurídico-penal brasileiro e a necessidade de elaboração de normas que tutelem a produção e comercialização de produto ao menos potencialmente lesivo}

Em nosso ordenamento jurídico, como visto no segundo capítulo, as previsões legais que dizem respeito à colocação de produtos no mercado de consumo, podem ser encontradas em diversos diplomas normativos.

As Leis $n^{\circ} .8 .078$ de 11 de setembro de 1990 (Código de Defesa do Consumidor CDC) e $\mathrm{n}^{\circ} .8 .137$ de 27 de dezembro de 1990 (Crimes contra a ordem tributária, econômica e as relações de consumo), que tutelam, respectivamente, o consumidor e as relações de consumo, bem como, a Lei $\mathrm{n}^{\circ}$. 1.521 de 26 de dezembro de 1951 (Crimes contra a Economia Popular) são acompanhadas pelo Código Penal (Decreto-Lei nº 2.848 de 07 de dezembro de 1940) que, ao tratar dos Crimes contra a Saúde Pública acaba tutelando reflexamente o consumidor.

São poucos, limitados e insuficientes ao fim a que se destinam - a tutela do consumidor, sendo ele pensado individual ou coletivamente - os dispositivos que tratam da proteção ao consumidor frente à produção e comercialização de produtos defeituosos.

Apesar do amplo conceito de produto apresentado pela Lei $\mathrm{n}^{\circ}$. 8.078/90, ao tutelar vida, integridade física e saúde do consumidor, o ordenamento jurídico-penal brasileiro dá especial importância a um limitado rol de produtos eventualmente perigoso. Todos eles, certamente, muito relevantes, mas não únicos.

Será feita a análise, a seguir, da tutela penal diante de alguns produtos que receberam especial atenção do legislador, gerando em alguns casos proteção desnecessária e em outros, insuficiente; e, da proteção do consumidor diante de produtos não especificados. Como se verá, a seguir, dentre os casos específicos, merecem destaque os alimentos e medicamentos. 


\section{a) Produtos alimentícios e bebidas}

- O art. 272 do Código Penal criminaliza a falsificação, corrupção, adulteração ou alteração de substância ou produtos alimentícios (caput) e bebidas com ou sem teor alcoólico $\left(\S 1^{\circ}\right)$, que os torne nocivos à saúde ou que reduza seu valor nutritivo, bem como a venda, importação, o depósito para a venda ou qualquer forma de distribuição das referidas mercadorias, cominando a pena de quatro a oito anos de reclusão e multa para a modalidade dolosa (caput) e um a dois anos de detenção e multa para a forma culposa $\left(\S 2^{\circ}\right)$.

- $\mathrm{O}$ art. 274 do Código Penal criminaliza o emprego de revestimento, gaseificação artificial, matéria corante, substância aromática, anti-séptica, conservadora ou qualquer outra não expressamente permitida pela legislação sanitária no fabrico de produto destinado a consumo. A esta conduta prevê a pena de reclusão de um a cinco anos de reclusão e multa.

- $\mathrm{O}$ art. 275 do CP tipifica a conduta de inculcar, ou seja, indiciar, apontar, citar, demonstrar, em invólucro ou recipiente de produtos alimentícios a existência de substância que não se encontra em seu conteúdo ou que nele existe em quantidade menor que a mencionada, cominando-lhe a pena de um a cinco anos de reclusão e multa.

- O art. 276, O Código Penal pune, ainda, com reclusão de um a cinco anos e multa aquele que vende, tem em depósito para venda ou, de qualquer forma, entrega a consumo os produtos nas condições dos arts. 274 e 275, acima referidos (art. 276), e também, substância destinada à falsificação de produtos alimentícios (art. 277).

b) Produtos destinados a fins terapêuticos ou medicinais: medicamentos, matériasprimas, insumos farmacêuticos e os de uso em diagnóstico

- É crime punido com pena de dez a quinze anos de reclusão e multa, conforme o art. 273 do CP, falsificar, corromper, adulterar ou alterar produto destinado a fins terapêuticos ou medicinais (caput), bem como, a venda, exposição à venda, depósito para a venda ou qualquer forma de distribuição ou entrega a consumo dos referidos produtos falsificados, corrompidos, adulterados ou alterados $\left(\S 1^{\circ}\right)$. 
- Conforme o $\S 1^{\circ}$-A do referido artigo, incluem-se em sua previsão, dentre outros, os medicamentos, as matérias-primas, os insumos farmacêuticos e os de uso em diagnóstico.

- $\mathrm{O} \S 1^{\mathrm{o}}$-B estende ainda mais a norma, entendendo como prática das ações previstas pelo $\S 1^{\circ}$, ou seja, a venda, exposição à venda, depósito para a venda ou qualquer forma de distribuição ou entrega a consumo dos referidos produtos nas seguintes condições: I - sem registro, quando exigível, no órgão de vigilância sanitária competente; II - em desacordo com a fórmula constante do registro previsto no inciso anterior; III - sem as características de identidade e qualidade admitidas para a sua comercialização; IV - com redução de seu valor terapêutico ou de sua atividade; V - de procedência ignorada; VI - adquiridos de estabelecimento sem licença da autoridade sanitária competente.

- Em qualquer dos casos, é admitida a modalidade culposa, por força do $\S 2^{\circ}$, modalidade para qual é prevista a pena de detenção de um a três anos e multa.

- Importa ressaltar que a Lei $\mathrm{n}^{\circ} .9 .695$ de 20 de agosto de 1998 incluiu o artigo 273

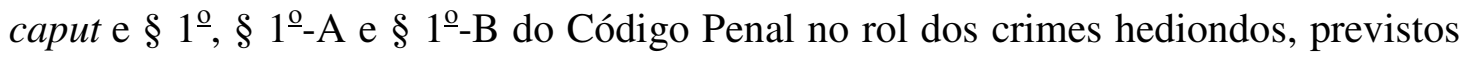
pela Lei $n^{\circ} .8 .072 / 90$. Deste modo, passaram a ser considerados, por força do artigo $2^{\circ}$ da Lei de Crimes Hediondos, crimes inafiançáveis (II) e insuscetíveis de anistia, graça e indulto (I). Além disso, o cumprimento da pena deve ocorrer inicialmente em regime fechado $\left(\S 1^{\circ}\right)$ e a progressão de regime se dá, somente, após o cumprimento de dois quintos da pena, se o apenado for primário, e de três quintos, se reincidente.

- $\mathrm{O}$ art. 274 do Código Penal, que criminaliza o emprego de revestimento, gaseificação artificial, matéria corante, substância aromática, anti-séptica, conservadora ou qualquer outra não expressamente permitida pela legislação sanitária no fabrico de produto destinado a consumo, pode também ser aplicado no que diz respeito aos produtos aqui tratados. A pena cominada a esta conduta é de reclusão de um a cinco anos de reclusão e multa.

- O art. 275 do CP tipifica a conduta de inculcar, ou seja, indiciar, apontar, citar, demonstrar, em invólucro ou recipiente, a existência de substância que não se encontra em conteúdo, não apenas de produtos alimentícios, mas, também, daqueles terapêuticos ou medicinais ou que neles existem em quantidade menor que a mencionada, cominando-lhe a pena de um a cinco anos de reclusão e multa. 
- É, ainda, proibida a venda, o depósito para venda ou qualquer forma de entrega a consumo dos produtos nas condições previstas pelos arts. 274 e 275, anteriormente citados (art. 276), bem como, de substância destinada à falsificação de produtos terapêuticos ou medicinais (art. 277). Para estas condutas prevê a reclusão de um a cinco anos e multa.

- Por fim, o art. 280 do CP criminaliza o fornecimento de substância medicinal em desacordo com receita médica, cominando, para tal, a pena de um a três anos de detenção ou multa para a modalidade dolosa e detenção de dois meses a um ano, conforme o parágrafo único, para a culposa.

\section{c) Produtos cosméticos e saneantes}

- A Lei $n^{\circ} .9 .677 / 98$ de 2 de julho de 1998, inclui no art. 273, o $\S 1^{\circ}$-A que determina como integrantes dos produtos nele referidos não apenas os medicamentos, as matérias-primas, os insumos farmacêuticos e os de uso em diagnóstico, mas, também cosméticos e saneantes.

Igualar as condutas de venda de um medicamento, por exemplo, com redução de seu valor terapêutico $\left(\S 1^{\underline{o}}-\mathrm{B}, \mathrm{IV}\right)$, à venda de um cosmético sem registro ( $\S 1^{\mathrm{o}}$-A combinado com $\S 1^{\underline{o}-B}$, I) já seria irracional e desproporcional, porém, torna-se ainda mais absurda a constatação de que a venda de qualquer cosmético ou saneante nas condições previstas pelo artigo 273 do CP é considerada pelo ordenamento jurídicopena brasileiro crime hediondo.

\section{d) Outras substâncias}

- $\quad \mathrm{O}$ art. 278 do CP trata de outras coisas ou substâncias nocivas à saúde ainda que não destinadas à alimentação ou a fim medicinal, cominando a pena de detenção de um a três anos e multa para quem as fabricar, vender, expor à venda, ter em depósito para vender ou, de qualquer forma, entregar a consumo. Este crime admite, em seu parágrafo único a modalidade culposa para o qual prevê a pena de detenção de dois meses a um ano. 


\section{e) Produtos em geral:}

- É considerado crime a omissão de dizeres ou sinais ostensivos sobre a nocividade ou periculosidade de produtos, nas embalagens, nos invólucros, recipientes ou publicidade (art. 63, caput, CDC). A punição para a modalidade dolosa é de detenção de seis meses a dois anos e multa e de um a seis meses ou multa para a culposa $\left(\S 2^{\circ}\right)$;

- A omissão de comunicação à autoridade competente e aos consumidores a respeito da nocividade ou periculosidade de produtos cujo conhecimento tenha sido posterior à sua colocação no mercado é tipificada pelo caput do artigo 64 do CDC com pena de seis meses a dois anos de detenção e multa.

- O art. 64, em seu parágrafo único, estende a pena do caput a quem deixar de retirar do mercado, imediatamente quando determinado pela autoridade competente, os produtos cujo conhecimento a respeito de sua nocividade ou periculosidade tenha sido posterior à sua colocação no mercado. Não fala, porém, do dever de retirada sem que a autoridade competente tenha o determinado;

- Fazer afirmação falsa ou enganosa, ou omitir informação relevante sobre a natureza, característica, qualidade, quantidade, segurança, desempenho, durabilidade, preço ou garantia de produtos, também são condutas criminalizadas pelo CDC. O art. 66 do referido diploma prevê detenção de três meses a um ano e multa para quem as praticar e, conforme $\S 1^{\circ}$, também para aquele que patrocinar as referidas ofertas. Para a modalidade culposa, a pena prevista é de detença de um a seis meses ou multa $\left(\S 2^{\circ}\right)$;

- A Lei $n^{\circ}$. 8.137/90, que tutela as relações de consumo, por sua vez, prevê em seu art. $7^{\circ}$, IX, a pena de detenção de dois a cinco anos ou multa para o crime de venda, depósito ou exposição para a venda, ou ainda, qualquer forma de entrega de matériaprima ou mercadoria, em condições impróprias ao consumo. Admite, ainda, em seu parágrafo único, a modalidade culposa, com redução da pena de detenção de um terço ou a de multa à quinta parte.

Deve-se lembrar que, conforme o art. $18, \S 6^{\circ}$ do CDC, consideram-se impróprios para o consumo: (I) os produtos cujos prazos de validade estejam vencidos; (II) os produtos deteriorados, alterados, adulterados, avariados, falsificados, corrompidos, fraudados, nocivos à vida ou à saúde, perigosos ou, ainda, aqueles em desacordo com as normas regulamentares de fabricação, distribuição ou apresentação; (III) os produtos que, por qualquer motivo, se revelem inadequados ao fim a que se destinam. 
Após o estudo da legislação no que se refere à proteção do consumidor diante dos riscos causados pela colocação de produtos defeituosos no mercado de consumo, fica clara a omissão legislativa nesta seara. Especial atenção deve-se dar ao caso, já mencionado no Capítulo 2, do veto do artigo 62 do Código de Defesa do Consumidor ${ }^{338}$ que criminalizava a colocação no mercado, fornecimento ou exposição para fornecimento de produtos (ou serviços) impróprios, cominando para tais condutas se praticadas com dolo, a pena de detenção de seis meses a dois anos e multa, se praticadas com culpa, de três meses a um ano ou multa $\left(\S 1^{\circ}\right) . \mathrm{O} \S 2^{\circ}$ do referido artigo, ainda previa que as penas ali previstas eram aplicáveis sem prejuízo das correspondentes à lesão corporal e à morte.

Ao tratar de produto em condições impróprias ao consumo, a Lei $\mathrm{n}^{\circ}$. 8.137/90, por seu turno, tipifica apenas e tão somente condutas referentes à circulação (venda, depósito ou exposição para a venda, ou ainda, qualquer forma de entrega) de mercadoria ou matériaprima, não tratando, em nenhum ponto, do momento relativo ao planejamento e fabricação do produto, momento este, essencial e apto a dar ensejo aos defeitos mais relevantes naquilo que se refere à quantidade de pessoas que virão a ser eventualmente lesadas. Isso ocorre, pois, como já referido, os defeitos de concepção geram problemas na totalidade dos produtos fabricados; os defeitos de fabricação, por sua vez, se refletem em séries inteiras, enquanto os defeitos de comercialização causam o vício em apenas uma pequena parcela de produtos.

Faz-se necessário, portanto, preencher esta lacuna no ordenamento jurídico-penal brasileiro, sempre observando, por óbvio, os limites constitucionais.

\subsection{Limites a uma responsabilidade penal pelo produto}

Embora seja clara a necessidade de o Direito Penal cumprir sua função social diante dos novos riscos trazidos pela fabricação e comercialização em massa de produtos perigosos, ainda mais claro é o imperativo de se buscarem limites precisos a este objetivo,

\footnotetext{
${ }^{338}$ Art. 62 - Colocar no mercado, fornecer ou expor para fornecimento produtos ou serviços impróprios. Pena - Detenção de seis meses a dois anos e multa. $§ 1^{\circ}$ - Se o crime é culposo: Pena - Detenção de três meses a um ano ou multa. $\S 2^{\circ}$ - As penas deste artigo são aplicáveis sem prejuízo das correspondentes à lesão corporal e à morte.
} 
para que não sejam afrontados princípios de garantia contra o jus puniendi, decorrentes de longa luta social. ${ }^{339}$

Devem ser, neste sentido, encontrados os limites à intervenção penal no âmbito da responsabilidade penal pelo produto na teoria do bem jurídico, na imputação subjetiva da autoria, tratados anteriormente e nos princípios penais, conforme análise a seguir.

Os princípios penais que devem ser observados para que se proceda à imputação da responsabilidade penal pelo produto são: Societas delinquere non potest, Princípio da Lesividade, Princípio da Intervenção Mínima e Princípio da Culpabilidade.

a) Societas delinquere non potest: no Brasil, apenas em relação aos crimes praticados contra o meio-ambiente podemos falar em responsabilidade penal da pessoa jurídica.

De qualquer forma, como amplamente discorrido no capítulo anterior, não é possível a responsabilidade penal da pessoa jurídica imputação por respeito ao princípio societas delinquere non potest que determina que entes coletivos não cometem crimes, restando a eles a possibilidade de prática de ilícitos civis e administrativos. Esta é a posição adotada por nossa tradição jurídica romano-germânica, ainda que alguns países desta tradição tenham admitido a corrente oposta ${ }^{340}$ (societas delinquere potest) e que parte de nossa doutrina ${ }^{341}$ o entenda como abolido. De qualquer modo, ainda que não fosse assim, e se admitisse a responsabilidade penal dos entes coletivos, o ordenamento jurídico brasileiro não prevê esta opção para nenhum crime além daqueles contra o meio ambiente.

b) Princípio da Lesividade: este princípio determina que a atuação do Direito Penal seja limitada aos casos em que o bem jurídico tutelado sofra alguma lesão ou perigo de lesão ${ }^{342}$, que seja provocado por alguém que não o seu titular. Os casos dignos de

\footnotetext{
${ }^{339}$ Segundo Renato de Mello Jorge Silveira: “O Direito Penal de Risco é um Direito Penal de Perigo, mas isso não significa que devam ser abandonadas todas as armas dogmáticas que determinam a justeza da aplicação da lei penal. Ao contrário, ele deve utilizá-las, até mesmo para que se legitime a própria aplicação da lei, e não que esta assuma o mero efeito simbólico, mostrando-se inaplicável”. SILVEIRA, Renato de Mello Jorge. op. cit., p. 160.

${ }^{340}$ Holanda, França e Dinamarca.

${ }^{341}$ A Professora Ivette Senise Ferreira assevera "designando como infratores ecológicos as pessoas físicas ou jurídicas o legislador,(...)abriu caminho para um novo posicionamento do Direito Penal do futuro, com a abolição do princípio ora vigente o qual societas delinquere non potest". FERREIRA, Ivette Senise. A tutela penal do meio ambiente. In: BENJAMIN, Antonio Herman V. (Coord.). Dano ambiental: prevenção, reparação e repressão. São Paulo: Revista dos Tribunais, 1993. p. 314.

${ }^{342}$ Para Nilo Batista, o Princípio da Lesividade é aquele "segundo o qual nenhum direito pode legitimar uma intervenção punitiva quando não medeie, pelo menos, um conflito jurídico, entendido como a afetação de um bem jurídico, total ou parcialmente alheio, individual ou coletivo". BATISTA, Nilo; ZAFFARONI, E.
} 
tutela penal no âmbito da responsabilidade pelo produto são aqueles que portem defeitos causados em decorrência de dolo ou culpa de agente atuante na cadeia empresarial - que sejam capazes de causar, ao menos, perigo aos bens jurídicos vida, saúde e integridade física. A propriedade do consumidor, neste sentido, não integra o rol de bens jurídicos que merecem ser tutelados pelo direito penal, pois pode ser satisfatoriamente protegida e ressarcida por outros ramos do ordenamento jurídico, no exemplo, o Direito Civil. Isto fica claro ao se verificar a norma prevista no art. 74 do CDC que só diria respeito, se tanto, à propriedade: "deixar de entregar ao consumidor o termo de garantia adequadamente preenchido e com especificação clara de seu conteúdo". Qualquer prejuízo financeiro que o consumidor viesse a ter por conta do preenchimento inadequado do termo de garantia pode ser suprido por indenização decorrente de responsabilidade civil.

c) Princípio da Intervenção Mínima: alguns autores consideram que adotar uma responsabilidade penal por resultado causado pela fabricação ou comercialização de produtos acabaria por ferir o Princípio da Intervenção Mínima que determina que este ramo do ordenamento jurídico só deva ser utilizado ultima ratio, ou seja, diante das mais graves infrações aos bens jurídicos mais importantes à vida em sociedade e ao livre desenvolvimento pessoal ${ }^{343}$. Ocorre que, neste momento do desenvolvimento social $^{344}$, a colocação de produtos no mercado de consumo traz, muitas vezes, e por diversas razões, potencial de causação de resultados lesivos, indetectável até sua realização, imensurável e incontrolável ${ }^{345}$. Medicamentos, brinquedos, automóveis e alimentos, nesse sentido, podem, uma vez colocados no mercado de consumo, ali permanecer muitos anos, com o potencial de causar danos à vida, à saúde e à integridade física de um enorme número de pessoas. Não se pode dizer, deste modo, que se fere o Princípio da Intervenção Mínima a adoção do Direito Penal na responsabilidade penal pelo produto. Vida, saúde e integridade física elencam os bens

Raúl; ALAGIA, Alejandro; SLOKAR, Alejandro. Direito penal brasileiro: teoria geral do direito penal. 2. ed. Rio de Janeiro: Revan, 2003. v. 1, p. 226.

${ }^{343}$ Neste sentido, MUÑOZ CONDE, Francisco; HASSEMER, Winfried. La responsabilidad por el producto en derecho penal, cit.

${ }^{344}$ Ao qual Ulrick Beck chama de modernidade reflexiva, entendida como o momento em que o progresso científico acaba por trazer uma série de efeitos secundários que podem ser capazes de gerar a destruição ao invés de incrementar a segurança. BECK, Ulrich. La sociedad del riesgo: hacia una nueva modernidad, cit.

${ }^{345} \mathrm{O}$ caso do Contergan, mais a frente descrito, demonstra inequivocamente a dimensão dos danos que podem decorrer da colocação de um produto no mercado. O caso Fox, também descrito adiante, por sua vez, é exemplo claro da impossibilidade de controlar os riscos, desta forma, provocados, uma vez que, por muitos anos ainda haverá a possibilidade de proprietários desses automóveis, ignorando seu potencial lesivo, terem seus dedos amputados pelo equivocado manuseio do mecanismo de rebatimento do banco traseiro. 
jurídicos tradicionalmente tutelados pelo Direito Penal. O fato de esses eventos poderem ser provocadas no âmbito empresarial, não tem o condão de afastar a tutela deste que é o meio mais efetivo para tutela de bens jurídicos. Ao contrário, pela própria natureza da estrutura empresarial, os resultados possíveis seriam muito mais graves que aqueles causados individualmente, não se podendo, portanto, falar em violação ao princípio em análise. Não seria razoável que uma lesão corporal grave causada por um indivíduo a outro por um motivo qualquer fosse penalmente reprovável e a mesma lesão causada por alguém que tem a capacidade de decisão em uma cadeia empresarial - que, por definição, tem como finalidade o lucro - e que tenha tomado a decisão de colocar o consumidor em risco baseando-se em critérios econômicos, não fosse. No caso da tutela dos bens jurídicos vida, saúde e integridade física do consumidor a responsabilidade penal pelo produto é indispensável ${ }^{346}$.

d) Princípio da Culpabilidade: este princípio determina, dentre outras coisas, que para que um fato seja penalmente imputado a alguém, esta pessoa deve ter contribuído para o resultado, ainda que culposamente ${ }^{347}$. A responsabilidade penal pelo produto deve observar rigidamente este princípio para que não caia na possibilidade de responsabilizar objetivamente alguém ainda que dentro da cadeia empresarial. Isto acontece corriqueiramente no quando se busca a responsabilidade penal pelo produto nos dias atuais. O caso da empresa Vonpar, produtora de refrigerantes da marca CocaCola é perfeito exemplo da visão que se tem a respeito da responsabilidade penal na seara da colocação de produtos no mercado de consumo. Os dirigentes da empresa foram denunciados pelo Ministério Público, ainda que ausente a conduta de cada um deles. Não houve atuação nem culposa e muito menos dolosa da parte dos referidos dirigentes aos quais foi atribuída a prática do crime previsto no art. $7^{\circ}$, IX, da Lei $\mathrm{n}^{\circ}$. $8.137 / 90$, por terem sido encontradas na empresa três garrafas de refrigerante contendo

\footnotetext{
${ }^{346}$ Conforme Miguel Reale Júnior, “o recurso à intervenção penal cabe apenas quando indispensável, em virtude de que tem o Direito Penal caráter subsidiário, devendo constituir a ultima ratio e, por isso, ser fragmentário, pois o antijurídico penal é restrito em face do antijurídico decorrente do Ordenamento, por ser obrigatoriamente seletivo, incriminando apenas algumas das condutas lesivas a determinado valor, as de grau elevado de ofensividade". REALE JÚNIOR, Miguel. Instituições de direito penal: parte geral, 3. ed., cit., p. 25.

${ }^{347}$ Cf. Nilo Batista, "o principio da culpabilidade deve ser entendido, em primeiro lugar, como repúdio a qualquer espécie de responsabilidade pelo resultado, ou responsabilidade objetiva. Mas deve igualmente ser entendido como exigência de que a pena não seja infligida senão quando a conduta do sujeito, mesmo associada causalmente a um resultado, lhe seja reprovável (...) O principio da culpabilidade impõe a subjetividade da responsabilidade penal. Não cabe, em direito penal, uma responsabilidade objetiva, derivada tão-só de uma associação causal entre a conduta e um resultado de lesão ou perigo para um bem jurídico. È indispensável a culpabilidade". BATISTA, Nilo. Introdução crítica ao direito penal brasileiro. 9. ed. Rio de Janeiro: Ed. Revan, 2004.
} 
mofo, o que as torna impróprias ao consumo. A companhia, porém, respeita todas as regras para a fabricação de refrigerantes, sejam elas administrativas ou legais, bem como os manuais de boas práticas de fabricação, não se podendo, portanto, falar em dolo nem mesmo em culpa de funcionários que trabalham diretamente com os produtos e, menos ainda, dos diretores da sociedade empresária. Esse tipo de responsabilização deve ser afastado por ferir gravemente o princípio da culpabilidade. Só se pode imputar a alguém responsabilidade penal em decorrência de conduta própria dolosa ou culposa.

\subsection{Tipos propostos de lege ferenda: a criminalização da produção e colocação no mercado de consumo de produto que exponha o consumidor a perigo}

Diante de tudo o que foi até agora exposto, nota-se, dentre as infrações penais previstas pelo ordenamento jurídico brasileiro, em especial, pelo Código de Defesa do Consumidor, com o intuito de tutelar a segurança do consumidor frente à colocação de produtos defeituosos, aptos a colocar em risco sua vida, saúde e integridade física, a ausência de norma penal incriminadora que tenha o condão de desestimular as condutas de técnicos, empresários e comerciantes ${ }^{348}$, ocorridas desde o planejamento e produção até a colocação de produtos no mercado de consumo, e que sejam capazes de gerar os sobreditos defeitos nos bens de consumo. Após a constatação desta insuficiência, faz-se mister a proposta de preenchimento das referidas lacunas por meio da elaboração de figuras típicas pertinentes e suficientes à solução da questão.

Optou-se por não determinar uma pena a cada uma das condutas, visto que a tal tarefa demanda um profundo estudo de proporcionalidade em todo o ordenamento jurídicopenal que acabaria por fugir do objeto do presente trabalho.

Para cada âmbito de responsabilidade pelo produto, ou seja, para cada espécie de atuação possível dentro da cadeia que vai do planejamento e fabricação à comercialização do produto, sugere-se, de lege ferenda, um tipo penal específico, destinado às ações do técnico, do dirigente e do comerciante, respectivamente. Propõe-se, deste modo, que sejam

\footnotetext{
348 Os vocábulos "técnico", "empresário" e "comerciante" estão, aqui, aplicados em termos genéricos. A abrangência de cada elemento dos tipos propostos será esclarecida posteriormente.
} 
acrescentados os seguintes artigos à Lei $\mathrm{n}^{\circ} .8078$ de 11 de setembro de 1990, Código de Defesa do Consumidor:

Art. 63-A. Abonar, no desempenho de função para a qual seja, ou deveria ser, profissionalmente qualificado, produto destinado a consumo, que sabe ou deveria saber, em razão de seu conhecimento técnico ou científico, expor a perigo a vida, a saúde ou a integridade física do consumidor.

Pena -

$\S 1^{o}$. Se a conduta é culposa:

Pena -

Art. 63-B. Decidir, no desempenho de função, ainda que por voto proferido em órgão colegiado, pela colocação ou manutenção no mercado de consumo, de produto que saiba ou deveria saber, em decorrência do exercício de sua função, expor a perigo a vida, a saúde ou a integridade física do consumidor.

Pena -

$\S 1^{o}$. Se a conduta é culposa:

Pena-

$\S 2^{\circ}$.

Art. 63-C. Oferecer, de qualquer modo, a consumo produto que saiba ou deveria saber expor a perigo a vida, a saúde ou a integridade física do consumidor.

Pena -

$\S 1^{o}$. Se a conduta é culposa:

Pena-

\subsubsection{Análise dos tipos propostos}

A análise de cada um dos tipos apresentados será realizada de modo individual naquilo em que se distinguem. Preliminarmente, no entanto, serão expostos os elementos nos quais coincidem: justificativa, objetividade jurídica e sujeito passivo.

a) Justificativa: busca-se com os tipos propostos garantir o direito básico do consumidor à proteção à vida, saúde e integridade física, bem como, à segurança contra os riscos provocados produtos considerados perigosos ou nocivos (CDC, art. $6^{\circ}$, I). Busca-se, também, reforçar a obrigação do fornecedor de limitar a colocação de produtos no mercado àqueles que não acarretem riscos à saúde ou segurança dos consumidores, 
exceto os considerados normais e previsíveis em decorrência de sua natureza e fruição $\left(\mathrm{CDC}, \operatorname{art} .8^{\circ}\right)$.

b) Objetividade jurídica: intenta-se por meio dos dispositivos em análise, tutelar a saúde, a vida e a integridade física dos consumidores contra produtos defeituosos oferecidos ao mercado de consumo.

c) Sujeito passivo: o sujeito passivo nos três tipos penais apresentados é o consumidor do produto defeituoso, este entendido em sentido amplo, ou seja, toda e qualquer pessoa física colocada em risco pelo contato com o produto que ofereça perigo à vida, à saúde ou à integridade física, além daquele que legitimamente se poderia esperar.

A seguir, será realizada a análise individual de cada um dos elementos restantes dos três tipos acima propostos:

- Art. 63-A. Abonar, no desempenho de função para a qual seja, ou deveria ser, profissionalmente qualificado, produto destinado a consumo, que sabe ou deveria saber, em razão de seu conhecimento técnico ou científico, expor a perigo a vida, a saúde ou a integridade física do consumidor.

Pena-

$\S 1^{\circ}$. Se a conduta é culposa:

Pena-

a) Conceito: o tipo em análise visa à proteção do consumidor diante de defeitos que venham a surgir no momento em que ocorre a gênese do produto. Desde sua idealização, passando por todas as etapas de desenvolvimento, daí incluída a fase de testes, até sua efetiva produção. Procura-se frisar a necessidade de serem observados, além das normas legais, os regulamentos administrativos, os critérios gerais e específicos de segurança (as chamadas "regras de boa prática”), os limites do risco permitido, bem como, os deveres objetivos de cuidado na fabricação de um bem de consumo, em especial, daqueles que, por serem oriundos de empresas de grande porte, possuem a capacidade de atingir uma imensa gama de consumidores.

b) Classificação doutrinária: trata-se de crime próprio quanto ao sujeito ativo e comum quanto ao sujeito passivo; de perigo concreto; doloso; formal; comissivo; instantâneo; unissubjetivo; unissubsistente. 
c) Sujeito ativo: há, ao longo da linha de produção de uma organização complexa, além de funcionários que apenas obedecem a ordens de seus superiores hierárquicos, um profissional responsável, por cada uma das etapas da fabricação do produto: planejamento, desenvolvimento, testes, produção propriamente dita e controle de qualidade. É da responsabilidade desses profissionais, ao exercer sua função, verificar se estão sendo observadas uma série de $\operatorname{regras}^{349}$, que vão da higiene pessoal ao transporte do produto acabado, passando pelo armazenamento das matérias-primas e as etapas de fabricação ${ }^{350}$. Esse profissional pode ser um engenheiro civil responsável pelo cálculo estrutural de um edifício ${ }^{351}$ ou por acompanhar sua obra; um engenheiro químico, responsável por adicionar um composto químico a um brinquedo ${ }^{352}$; um designer de automóveis, cuja função é projetar um mecanismo de rebatimento para o banco traseiro de um veículo ${ }^{353}$ ou controlar a fidelidade ao projeto em sua fabricação; um farmacêutico, que deve elaborar um medicamento ${ }^{354}$ ou atestar sua qualidade final. Enfim, há uma infinidade de profissionais peritos em suas áreas de expertises que podem atestar para a direção de uma empresa a segurança de um produto, nas mais diversas etapas de sua produção. Pode haver uma série de profissionais trabalhando de forma associada na mesma área, mas há aquele, específico, que deve chancelar legalmente o produto. Nos exemplos dados, um cálculo estrutural deve sempre ser assinado por um engenheiro regularmente inscrito no Conselho Regional de Engenharia, Arquitetura e Agronomia (CREA), bem como, o Engenheiro Químico ${ }^{355}$ e o designer de automóveis. O farmacêutico deve ter registro no Conselho Regional de Farmácia, sem o qual não pode ser o farmacêutico responsável por nenhum medicamento. Todos esses profissionais especializados devem pautar seu trabalho na segurança do consumidor a que se destina o produto, e é a eles que se dirige este mandamento, sendo, portanto, os sujeitos ativos do tipo, ora em análise.

\footnotetext{
${ }^{349}$ Os chamados "Manuais de Boas Práticas" trazem regras criteriosamente detalhadas a respeito dos procedimentos que devem ser adotados nas mais diversas indústrias para tenham sua margem de risco seja reduzida a um mínimo possível.

${ }^{350}$ Os Manuais de Boas Práticas de fabricação de alimentos, cosméticos, insumos farmacêuticos, medicamentos, produtos para saúde e saneantes podem ser encontrado no site da ANVISA. Disponível em: $<$ http://www.anvisa.gov.br/inspecao/boas.htm>, desde 2005, devem ser submetidos à certificação compulsória do Inmetro, conforme o artigo $1^{\circ}$ da Portaria $n^{\circ} 108$ de 13 de junho de 2005 do Ministério do Desenvolvimento, Indústria e Comércio Exterior.

${ }^{351}$ Exemplo que pode ser ilustrado com o caso do "Edifício Palace II".

${ }^{352}$ Como no caso dos brinquedos "Aqua dots".

${ }^{353}$ Fato que pode ser observado no caso "Fox".

${ }^{354} \mathrm{O}$ primeiro momento do caso Contergan é exemplar, neste sentido.

${ }^{355}$ Embora haja uma disputa entre o CREA e o Conselho Regional de Química, parece mais acertada e regular a primeira opção, uma vez que tratam-se de Engenheiros Químicos e não Químicos.
} 
d) Conduta: a conduta expressa no tipo é abonar, ou seja, declarar ou considerar bom ou verdadeiro, ratificar, sancionar, autorizar, dar como aprovado, apto, afiançar, garantir. Trata-se, portanto, de crime comissivo, que demanda a ação do funcionário no sentido de dar sua chancela ao produto. No que diz respeito ao sujeito ativo, o crime é próprio do funcionário profissionalmente qualificado, capaz de perceber o eventual caráter defeituoso do produto que está sendo planejado ou fabricado. Quanto ao sujeito passivo, é comum, uma vez que qualquer pessoa pode acabar tendo contato com o produto defeituoso.

e) Consumação: o crime é formal, independendo, portanto, de qualquer resultado. Aperfeiçoa-se o referido crime no momento em que o sujeito ativo entrega sua aprovação à empresa, remetendo o produto à etapa seguinte de produção. É instantâneo, inadmitindo, por isso, a tentativa.

f) Elemento subjetivo: o elemento subjetivo presente no caput é o dolo, ou seja, a vontade livre e consciente de abonar o produto que sabe ou deveria saber expor a perigo a vida, a saúde ou a integridade física do consumidor. A modalidade culposa é admitida no $\S 1^{\circ}$.

- Art. 63-B. Decidir, no desempenho de função, ainda que por voto proferido em órgão colegiado, pela colocação ou manutenção no mercado de consumo, de produto que saiba ou deveria saber, em decorrência do exercício de sua função, expor a perigo a vida, a saúde ou a integridade física do consumidor.

Pena-

$\S 1^{o}$. Se a conduta é culposa:

Pena-

a) Conceito: o tipo em exame pretende proteger o consumidor diante de produtos que embora tragam defeitos que sejam ou deveriam ser de conhecimento dos dirigentes da empresa, eles, por qualquer razão, em geral, de natureza econômica, acabem decidindo por sua colocação no mercado de consumo. Os dirigentes das empresas, ao decidirem pela comercialização de qualquer produto, já impõem ao consumidor riscos a ele inerentes. Não se pode, contudo, permitir que eles tenham um campo de decisão tão amplo que os faça capaz de optar pela disponibilização ao mercado de consumo de produtos cuja legitima expectativa de segurança esteja aquém dos riscos efetivamente impostos pelo produto. Os consumidores, de um modo geral, estão dispostos a correr 
riscos como o preço que devem pagar pela evolução tecnológica. No entanto, não pretendem correr riscos que sequer sabem existir. Ainda que se possa argumentar que a demanda do mercado seja por preço e facilidade de pagamento e não especificamente por segurança, cabe àqueles que têm a efetiva capacidade de decidir a respeito da colocação de produtos no mercado, que o façam de acordo com a segurança que deles se espera. Ainda com mais razão deve-se punir aquele dirigente que decidir por deixar de retirar do mercado de consumo, produto cujos indícios indiquem ser perigoso ao consumidor.

b) Classificação doutrinária: trata-se de crime próprio quanto ao sujeito ativo e comum quanto ao sujeito passivo; de perigo concreto; doloso; formal; comissivo; instantâneo; unissubjetivo; unissubsistente.

c) Sujeito ativo: é aquele que tenha, dentro da cadeia empresarial, o efetivo poder de proferir a decisão final a respeito da colocação de um produto no mercado de consumo. Pode ser a pessoa que ocupa o cargo de diretor da empresa, de presidente, de gerente de produto, ou qualquer outro, independente da denominação, mas que possua a capacidade de tomada de decisão em última instância. Há de se observar que esta função pode ser exercida apenas por uma pessoa, por mais de uma ou, ainda, por um órgão colegiado.

d) Conduta: a conduta expressa no tipo é decidir, ou seja, tomar decisão, deliberar, resolver, optar. Trata-se, deste modo, crime comissivo, próprio do dirigente da empresa que dele exige ação deliberativa, isto é, a declaração de sua posição que deverá se reverter em ordem no sentido de se colocar no mercado de consumo produto que ele saiba ou deveria saber, em decorrência do exercício de sua função, expor a perigo a vida, a saúde ou a integridade física do consumidor, além do legitimamente por ele esperado. A pessoa que decide na cadeia empresarial é, ou, ao menos, deveria ser informada pelos técnicos ou peritos a respeito das características de produto que virá a ser colocado no mercado de consumo. Se, eventualmente, ela souber de antemão que o produto contém um defeito que o torna perigoso além do legitimamente esperado pelo consumidor, deverá decidir contra a sua comercialização, ainda que isso represente alto prejuízo à empresa. O mesmo deve ocorrer quando se decidir pela manutenção no mercado de consumo de produtos nas condições anteriormente descritas. 
e) Consumação: o crime é formal, independendo, portanto, de qualquer resultado. Aperfeiçoa-se o referido crime no momento em que o sujeito ativo decide pela colocação ou manutenção do produto perigoso no mercado de consumo. Não admite tentativa.

f) Elemento subjetivo: o elemento subjetivo presente no caput é o dolo, ou seja, a vontade livre e consciente de decidir pela colocação ou manutenção no mercado de produto que sabe ou deveria saber expor a perigo a vida, a saúde ou a integridade física do consumidor. A modalidade culposa é admitida no $\S 1^{\circ}$.

- Art.63-C. Oferecer, de qualquer modo, a consumo produto que saiba ou deveria saber expor a perigo a vida, a saúde ou a integridade física do consumidor.

Pena -

$\S 1^{o}$. Se a conduta é culposa:

Pena-

a) Conceito: o referido tipo tem por objetivo tutelar o consumidor diante de defeitos que venham a surgir em qualquer momento da comercialização produto. Desde sua venda pela empresa fabricante até a entrega ao consumidor final, passando por sua todos os momentos de armazenagem e conservação.

b) Classificação doutrinária: trata-se de crime comum quanto aos sujeitos ativo e passivo; de perigo concreto; doloso; formal; comissivo; instantâneo; unissubjetivo; plurissubsistente.

c) Sujeito ativo: é qualquer pessoa que, de qualquer modo, ofereça o produto a consumo, não havendo a necessidade de tratar-se de comerciante.

d) Conduta: a conduta expressa no tipo é oferecer. Esta oferta pode ocorrer por meio de múltiplas formas: dar, proporcionar, mostrar, apresentar, expor, exibir, vender, ter em depósito para vender, expor à venda ou, de qualquer forma, entregar ou disponibilizar ao consumo o produto em questão. A entrega de produto perigoso à vida, saúde ou integridade física do consumidor é a conduta que se procura evitar. Admite-se tentativa.

e) Consumação: o crime é consumado com a oferta, como quer que ela ocorra. Admite-se tentativa. 
f) Elemento subjetivo: o elemento subjetivo presente no caput é o dolo, ou seja, a vontade livre e consciente de oferecer a consumo o produto que sabe ou deveria saber expor a perigo a vida, a saúde ou a integridade física do consumidor. A modalidade culposa é admitida no $\S 1^{\circ}$.

\subsubsection{A qualificação pelo resultado}

O delito qualificado pelo resultado é aquele no qual há, conforme MIGUEL REALE JÚNIOR, um delito-base a partir do qual é gerado um evento que o qualifica e aumenta a pena. O delito-base pode acabar gerando, como consequência direta, causalmente vinculada, o agravamento do resultado inicialmente pretendido, "transformando o perigo em dano efetivo, ou lesionando de modo mais grave o mesmo bem jurídico, ou ferindo bem jurídico diverso" ${ }^{356}$. Isso quer dizer que necessariamente haverá um nexo causal entre o delito-base e o resultado mais gravoso.

O delito-base, deste modo, trata de uma conduta que coloca o bem jurídico em determinada situação de perigo, perigo este, que irá se realizar como consequência, justamente, da prática do delito base, ou seja, da colocação do bem jurídico em perigo.

Importa ressaltar que no caso de delito qualificado pelo resultado, há a prática de apenas uma conduta, que pode vir a gerar mais do que um resultado. Ou seja, a ação é uma e dela pode decorrer a consumação do delito-base apenas ou, também, uma consequência mais grave

O delito-base pode decorrer de ação dolosa ou culposa. No caso de conduta culposa, o resultado será necessariamente culposo. Já no que diz respeito às condutas dolosas, o resultado pode ter sido previsível ao agente. Neste caso, tratar-se-á de resultado culposo. Por outro lado, se o autor houver assumido o risco da produção do resultado mais grave, o resultado será doloso, a título de dolo eventual. Não há que se falar em dolo direto, pois, neste caso, haveria uma outra tipificação à conduta.

Para o tratamento da responsabilidade penal pelo produto é essencial que as tipificações anteriormente propostas para as condutas dos possíveis responsáveis pela disponibilização de produtos potencialmente lesivos no mercado de consumo prevejam a

\footnotetext{
${ }^{356}$ REALE JÚNIOR, Miguel. Instituições de direito penal: parte geral, 3. ed., cit., p. 264.
} 
possibilidade de qualificação pelo resultado lesão corporal ou morte. Isso se faz necessário, uma vez que, os bens jurídicos penalmente tutelados nos tipos propostos são, justamente, a vida, a saúde e a integridade física do consumidor. Deste modo, é proposto o seguinte artigo para a qualificação do resultado dos crimes acima previstos:

Art. 63-D. Nos crimes dolosos previstos nos artigos 63-A, 63-B e 63-C, as penas serão aumentadas:

I - de um terço a metade, se, do uso ou consumo do produto resulta lesão corporal em outrem;

II - da metade a dois terços, se, do uso ou consumo do produto resulta lesão corporal de natureza grave em outrem;

III - até o dobro, se, do uso ou consumo do produto, resulta a morte de outrem.

\subsection{Casos paradigmáticos da responsabilidade penal pelo produto: descrição, análise e tipificação}

Para que se possa ilustrar tudo aquilo que foi apresentado até aqui, serão descritos a seguir casos relevantes da responsabilidade pelo produto ocorridos na Alemanha, Espanha e Brasil, a partir dos anos cinquenta do século XX.

Para que se proceda a uma análise frente à atual legislação brasileira e, também, para que sejam testados os tipos penais propostos será feita uma análise complementar nos casos em que os produtos tenham chegado ao mercado brasileiro.

Todos os casos aqui elencados apresentam, além do perigo, dano efetivo a bem jurídico do consumidor. Não é, no entanto, em todos os casos que se faz necessária a presença da resposta penal, sendo suficiente à reparação jurídica do dano, a responsabilidade civil.

\subsubsection{Caso "Contergan"}

Embora haja casos de produtos defeituosos, causadores de dano ao consumidor, anteriores a este ${ }^{357}$, o caso do medicamento Contergan, também conhecido como

\footnotetext{
${ }^{357}$ Cite-se, por exemplo, o caso dos pêlos de cabra, sentenciado pelo Tribunal Supremo do Império em 23 de setembro de 1929. Neste caso, um empresário havia comprado de um fornecedor chinês pêlo de cabra para ser usado como matéria prima em sua fabrica de pinceis. O empresário desprezou a recomendação do fornecedor para que o pelo fosse desinfetado, entregando-os a seus empregados. Como consequência da referida negligência quatro empregados morreram em decorrência de contaminação por bactérias. $\mathrm{O}$
} 
Talidomida, é considerado, na literatura especializada, como aquele que dá início ao estudo sistematizado da responsabilidade penal pelo produto $^{358}$. É a partir dele que surge a hipótese de se responsabilizar penalmente diretores de uma empresa pelos danos decorrentes do uso de um produto por ela fabricado e distribuído ${ }^{359}$.

Em diversos países, originaram-se processos, civis e penais, decorrentes de danos causados pelo uso do Contergan, tendo o principal deles ocorrido na Alemanha ${ }^{360}$ e sendo este o utilizado para que se trouxessem elementos à descrição a seguir.

Fundada em 1946, a indústria farmacêutica alemã Chemie Grünenthal, em outubro de 1957, coloca no mercado um medicamento com efeitos tranquilizantes que recebe o nome comercial de Contergan.

O medicamento, que podia ser comprado sem prescrição médica, era oferecido ao mercado de consumo como totalmente atóxico, isento de qualquer perigo e efeitos colaterais $^{361}$. Para torná-lo ainda mais atraente ao consumo, era apresentado em formas diversas: comprimido, xarope, gotas e supositório. Tornou-se, por isso, um imenso sucesso comercial nos cinquenta e um países onde foi vendido. Desde o seu lançamento em 1957 até 1961 este medicamento foi receitado a milhares de mulheres gestantes que, como consequência direta de seu uso durante os primeiros meses de gestação, acabaram por dar à luz bebês com gravíssimas deformidades físicas.

Em 1959, começaram a ser levantadas as primeiras suspeitas sobre a produção de efeitos colaterais (notadamente, problemas neurológicos em adultos) pelo uso do medicamento. Como resposta, a indústria produtora modificou a embalagem e a bula e alguns estados alemães condicionam a venda do Contergan à apresentação de prescrição médica $^{362}$. No início dos anos sessenta, porém, houve a ocorrência de diversos nascimentos de crianças portadoras de gravíssimas deformidades ${ }^{363}$ que, em alguns casos, acabavam as

empresário foi acusado de homicídio culposo. Durante o processo, o perito afirmou que mesmo que houvessem procedido a desinfecção dos pêlos com os produtos permitidos, as bactérias não teriam sido eliminadas. ROXIN, Claus. Infracción del deber y resultado en los delitos imprudentes. Problemas básicos del derecho penal. Madri: Reus, 1976. p. 149-150.

${ }^{358}$ SARRABAYROUSE, Eugenio C. op. cit., p. 38.

${ }^{359}$ ÍNIIGO CORROZA, Ma. Elena. La responsabilidad penal del fabricante por defectos de sus productos. Barcelona: J.M. Bosch, 2001. p. 58.

${ }^{360}$ SARRABAYROUSE, Eugenio C. op. cit., p. 38.

${ }^{361}$ 1967: início do processo da Talidomida na Alemanha. Disponível em: <http://www.dwworld.de/dw/article/0,,351856,00.html>. Acesso em: 15 jan. 2009.

${ }^{362}$ SARRABAYROUSE, Eugenio C. op. cit., p. 40.

${ }^{363}$ Os diversos relatos falam em graves deformidades nos olhos, em órgãos internos e nos membros que se apresentavam "enfocados", ou seja, com os pés diretamente ligados à pélvis, assim como as mãos ligadas diretamente aos ombros 
conduzindo à morte. Passou-se a suspeitar de que tais deformidades seriam consequência de causa única, apontada pelo pediatra Widukind Lenz durante um congresso ${ }^{364}$ como sendo o Contergan ${ }^{365}$. Mas foi somente com a divulgação de seus efeitos colaterais pela imprensa, alguns dias depois, que o medicamento foi retirado do mercado ${ }^{366}$. Isso ocorreu em 27 de novembro de $1961^{367}$.

Já em dezembro do mesmo ano, o Ministério Público iniciou ampla investigação. Tinha como foco cinco mil casos de danos neurológicos em adultos, bem como, um número entre cinco e sete mil casos de deformidades em crianças recém-nascidas cujas mães haviam tomado o medicamento durante a gestação.

O Ministério Público denunciou nove gerentes e cientistas da indústria pelos seguintes delitos: lesão corporal culposa; lesão corporal dolosa; homicídio culposo; infração dolosa a alguns artigos da Lei de Medicamentos por colocação no mercado de medicamento causador de dano à saúde por meio de publicidade enganosa ${ }^{368}$. A modalidade culposa de lesão corporal e homicídio foi adotada para os danos ocorridos antes do conhecimento do potencial lesivo do medicamento e a dolosa para os ocorridos após.

Muito se discutiu durante o extenso processo a respeito do estabelecimento da relação de causalidade entre o consumo do Contergan e as deformidades e danos neurológicos sofridos pelas vítimas. De acordo com o Ministério Público, havia uma série de provas do nexo causal: as mães de todos os bebês deformados haviam feito uso de Talidomida durante a gestação; a epidemia de deformidades em recém-nascidos ocorreu nas regiões onde o medicamento foi vendido, iniciou cerca de um ano após o início de sua venda e cessou um ano após sua retirada do mercado de consumo; experimentos realizados em laboratórios com cobaias apresentaram o mesmo resultado daqueles trazidos pelas crianças vitimadas pelo medicamento em questão. A defesa, por outro lado, sustentou: serem os efeitos do uso do Contergan desconhecidos; terem sido as lesões causadas por outras razões (radiação decorrente do aparelho de televisão, chuvas radioativas advindas de

\footnotetext{
${ }^{364}$ 1961: Contergan é retirado do mercado. Disponível em:<http://www.dw-world.de/dw/article/ 0,,678470,00.html>. Acesso em: 15 jan. 2009.

${ }^{365}$ SARRABAYROUSE, Eugenio C. op. cit., p. 40.

${ }^{366}$ A Talidomida é utilizada, atualmente, em diversos países, dentre os quais, o Brasil, sob rígido controle, no tratamento de hanseníase, bem como, de mieloma múltilplo. TALIDOMIDA banida do mercado há quarenta anos. Disponível em: <http://www.dw-world.de/dw/article/0,,338346,00.html>. Acesso em: 15 jan. 2009.

${ }^{367}$ 1961: Contergan é retirado do mercado, cit.

${ }^{368}$ SARRABAYROUSE, Eugenio C. op. cit., p. 41.
} 
experiências nucleares, tentativas malsucedidas de aborto, predisposição genética, entre outras); que muitas mulheres que usaram o medicamento tiveram filhos saudáveis; que a Talidomida não causou as deformidades, mas evitou o aborto espontâneo ou o parto prematuro de fetos com deformidades ${ }^{369}$.

No que diz respeito à causalidade, o Tribunal $^{370}$ determinou que para o estabelecimento da causalidade em sentido jurídico, basta que, após considerar todas as circunstâncias, o magistrado se convença plenamente da relação entre causa e resultado, sendo desnecessária prova científica natural capaz de excluir indubitavelmente outra causa $^{371}$. Dito de outro modo: é suficiente para que se declare o nexo causal o absoluto convencimento subjetivo do juiz.

O Tribunal, embora tenha afirmado que todos os diretores tinham conhecimento do potencial lesivo do Contergan, deixou de especificar a responsabilidade subjetiva de cada diretor, mas esclareceu que, de acordo com seu entendimento, eram corresponsáveis pelos diversos resultados lesivos, que foram considerados decorrentes de apenas um crime. Estabeleceu, entretanto, um rol de deveres direcionados a empresas produtoras de medicamentos e determinou que, diante da suspeita da existência de efeitos colaterais, caberia a ela um amplo dever de informar ao consumidor.

Em consonância com o princípio da oportunidade ${ }^{372}$, então vigente na Alemanha, o processo se encerrou com absolvição dos acusados e um acordo entre as partes no qual a Chemie Grünenthal se comprometeu a pagar cento e quatorze milhões de marcos e o governo alemão mais cem milhões a uma fundação criada, justamente, para administrar a indenização paga às vítimas.

Não houve, contudo, uma solução na esfera penal.

\footnotetext{
${ }^{369}$ SARRABAYROUSE, Eugenio C. op. cit., p. 45-47.

${ }^{370}$ Câmara Criminal de Aachen.

${ }^{371}$ SARRABAYROUSE, Eugenio C. op. cit., p. 47.

${ }^{372} \mathrm{De}$ acordo com o Princípio da Oportunidade, previsto no Código Processual Penal alemão (Oportunitütprinzip: OPP $§ 153$ ) e antecessor do Princípio da Insignificância, as contravenções não são perseguidas quando a culpabilidade do infrator for leve, a menos que haja interesse público em provocar uma decisão judicial.
} 


\subsubsection{Caso "Lederspray"}

Este é um dos episódios mais importantes da história da responsabilidade pelo produto. Sua importância se dá na medida em que, até então, os danos causados por produtos defeituosos só eram tratados na esfera civil, sendo, no julgamento deste caso, que trata de um spray para sapatos e outros artigos de couro, a primeira vez em que o Supremo Tribunal alemão (Bundesgerichtshof - $\mathrm{BGH}$ ) decidiu acerca da responsabilidade penal pelo produto.

O Lederspray, produzido pela empresa Werner und Mertz GmbH, era vendido por duas empresas filiais.

Em 1980, as empresas foram notificadas acerca de danos à saúde ${ }^{373}$ associados ao uso de seu produto.

No dia 12 de maio de 1981, todos os diretores da empresa Werner und Mertz $G m b H$ participaram de uma reunião na qual o químico responsável pelo laboratório central apresentou um relatório sobre o caso. Este relatório dizia que não havia no produto qualquer componente tóxico e que, portanto, não era perigoso. O relatório concluía ser desnecessária a retirada do produto do mercado. Recomendava, entretanto, que fossem feitas investigações por órgãos externos e que fossem colocados alertas nas embalagens.

As recomendações foram aprovadas. Os Diretores decidiram que só retirariam o produto do mercado quando e se as investigações apontassem um "autêntico defeito do produto" ou um "risco determinável derivado de seu uso".

As novas investigações também não identificaram a substância lesiva dentre os componentes do produto. E novos relatos acerca de danos associados a seu uso continuaram surgindo.

Somente em 1983 o spray foi, finalmente, retirado do mercado, pelo Ministério da Juventude, Família e Saúde alemão.

Os Diretores e o químico responsável pela empresa foram condenados pelas lesões causadas aos consumidores na forma omissiva dolosa por não terem retirado do mercado e

\footnotetext{
${ }^{373}$ Segundo Sarrabayrouse, os danos relatados eram distúrbios respiratórios, tosse, náuseas, calafrios, febre e, em alguns casos, se relacionavam com quadros de edema pulmonar. Houve relatos de pessoas que tiveram a necessidade de receber tratamento em unidades de terapia intensiva. SARRABAYROUSE, Eugenio C. op. cit., p. 53.
} 
terem continuado a fabricar o produto mesmo após os aparecimentos de relatos sobre o perigo.

A perícia não conseguiu demonstrar cientificamente o nexo causal entre as enfermidades produzidas e um exato elemento químico presente na composição do verniz. O Tribunal, porém, entendeu serem suficientes para se estabelecer a causalidade, a partir de um ponto de vista médico, os indícios existentes ${ }^{374}$.

Mesmo sem se conseguir precisar pericialmente a substância responsável pelos danos, o Tribunal de Mainz, onde o caso foi julgado, afirmou a existência da causalidade entre o uso do produto e os danos aos consumidores. O BGH manteve a condenação dos Diretores, mas absolveu o químico ${ }^{375}$.

O BGH entendeu que nesse tipo de caso o relevante é que se comprove com segurança que a composição do produto foi responsável por causar os danos, e não qual foi o exato elemento químico.

Segundo HASSEMER, para o Supremo Tribunal alemão, não há necessidade de se conhecer exatamente qual o elemento exato do produto que causou o dano, basta que se exclua a possibilidade de que outros fatores externos ao produto o tenham produzido ${ }^{376}$.

HASSEMER diz que essa construção é semelhante à da caixa-escura (black box) usada pelos mágicos nas quais se sabe o que acontece em sua entrada e sua saída - que seria a composição química do produto - mas cujo conteúdo, permanece um mistério. Sabe-se apenas que o produto guarda relação com os danos alegados; que não há outro fator que possa tê-los causado; mas, desconhece-se qual fator presente no composto do produto é nocivo ${ }^{377}$.

A questão que se coloca como fundamental a partir desta construção é a de se esse modelo de constatação de causalidade pode ser utilizado num Estado Democrático de Direito $^{378}$.

Importante também para este caso foi a posição de garante dos Diretores afirmada pelo $\mathrm{BGH}$, pois quem cria perigo a terceiros é obrigado a evitar resultado lesivo,

\footnotetext{
${ }^{374}$ MUÑOZ CONDE, Francisco; HASSEMER, Winfried. La responsabilidad por el producto en derecho penal, cit. p. 131.

${ }^{375}$ SARRABAYROUSE, Eugenio C. op. cit., p. 56.

${ }^{376}$ MUÑOZ CONDE, Francisco; HASSEMER, Winfried. La responsabilidad por el producto en derecho penal, cit. p. 133.

${ }^{377}$ Id., loc. cit.

${ }^{378}$ Id., loc. cit.
} 
independentemente da existência de uma negligência anterior quanto ao dever de cuidado e isso tem ainda mais importância no âmbito das relações de consumo.

A responsabilidade penal foi imputada aos diretores da empresa, pelo $\mathrm{BGH}$, pelo descumprimento do dever de retirada do produto perigoso do mercado ${ }^{379}$, portanto, por omissão.

De acordo com SARRABAYROUSE, a conduta dos Diretores foi avaliada em quatro momentos distintos:

$\left.1^{\circ}\right)$ Em um primeiro momento, o spray foi fabricado com os conhecimentos técnicos de então que não permitiam prever seu caráter nocivo. As lesões daí decorrentes foram atribuídas a um caso fortuito, sendo os Diretores, portanto, isentados de responsabilidade penal;

$2^{\circ}$ ) O segundo momento é aquele ocorrido no decurso de tempo entre as notificações de danos aos consumidores e a reunião de maio de 1981. Foi imprudente a não retirada do produto do mercado. Os Diretores foram responsabilizados pelos danos decorrentes deste período por omissão imprópria culposa;

$\left.3^{\circ}\right) \mathrm{O}$ terceiro diz respeito à comercialização do spray após a reunião, apesar dos fortes indícios do potencial lesivo do produto e à persistência em não retirar o produto do mercado. De omissão imprópria culposa, passam a responder por omissão a título de dolo eventual;

$4^{\circ}$ ) Por fim, a colocação no mercado de novos sprays após a reunião, trata-se de conduta comissiva dolosa.

\subsubsection{Caso "Holzschutzmittel"}

Este caso trata da colocação no mercado de consumo de um verniz para cobertura de madeira utilizado para a proteção do interior de residências, bem como, para trabalhos de bricolagem.

De um modo geral, em todos os vernizes produzidos na Alemanha nas décadas de sessenta e setenta havia um composto de pentaclorofenol (PCP) e lindano, ambas

\footnotetext{
${ }^{379}$ No Brasil, o dever de retirada de produto perigoso do mercado está previsto no artigo 64 do Código de Defesa do Consumidor.
} 
substâncias suspeitas de causar alterações à saúde dos consumidores e dos trabalhadores que o utilizavam ${ }^{380}$ e que, com o tempo, foram excluídas da composição dos protetores de madeira.

Antes do ajuizamento da ação penal, foi discutida civilmente, em diversas ações, a indenização pelos danos causados pelo uso do produto em questão. Foram apontadas tanto a responsabilidade contratual quanto a extracontratual dos fabricantes do verniz e de fabricantes de outros produtos que o utilizaram em sua construção. A utilização do verniz contendo PCP e lindano no interior de residências, mesmo abaixo da recomendada pelos órgãos administrativos alemães pertinentes, foi considerada pelo Tribunal como critério objetivo de perigo à saúde ${ }^{381}$.

Diante da enorme quantidade de denuncias recebidas quanto aos danos causados pelo verniz, o Ministério Público de Frankfurt inicia uma ampla investigação a respeito dos fatos e reduz a imputação a duas empresas líderes no mercado e a cento e setenta e duas vítimas dos efeitos nocivos do produto em questão ${ }^{382}$.

A denúncia, ocorrida em 1989, se restringiu a dois diretores da empresa Desowag: o responsável técnico e o responsável comercial pela empresa. Embora a empresa tenha se comprometido a auxiliar financeiramente as vítimas - como ocorrido no caso Contergan os diretores foram condenados pela Câmara Penal de Frankfurt. O Supremo Tribunal alemão cassou esta decisão e determinou a realização de novo julgamento ${ }^{383}$.

Um dos pontos altos desse caso é a distinção feita pelo Tribunal Superior de Frankfurt entre a metodologia das ciências naturais e a metodologia jurídica: as ciências naturais somente afirmam a causalidade respaldada em uma explicação satisfatória dos mecanismos causais e seus efeitos, já os juízes podem chegar ao convencimento através de uma "causalidade geral" mesmo sem se conclua por uma causalidade específica entre um elemento e os danos produzidos ${ }^{384}$.

\footnotetext{
${ }^{380}$ SARRABAYROUSE, Eugenio C. op. cit., p. 65.

${ }^{381}$ Id. Ibid., p. 66.

${ }^{382}$ Embora, inicialmente, houvesse denúncias partindo de cerca de oitocentas famílias supostamente afetadas pelo verniz, apenas cento e setenta e duas pessoas haviam, afinal, desenvolvido aquilo que se convencionou chamar de "síndrome do protetor de madeira": um conjunto de sintomas que englobava dor de cabeça, fadiga, transpiração, dificuldade de concentração, dores por todo o corpo etc. SARRABAYROUSE, Eugenio C. op. cit., p. 67-68.

${ }^{383}$ Id. Ibid., p. 68.

${ }^{384}$ MUÑOZ CONDE, Francisco; HASSEMER, Winfried. La responsabilidad por el producto en derecho penal, cit., p. 134.
} 
Segundo HASSEMER, a constatação da causalidade nas ciências naturais e nas ciências jurídica se dá através de metodologias e, também, com finalidades distintas: enquanto na primeira busca-se o conhecimento, na última busca-se a aplicação justa da $1 \mathrm{ei}^{385}$.

\subsubsection{Caso "Aceite de Colza"}

Na Espanha, em maio de 1981, diversas pessoas apresentaram uma associação de sintomas, nunca antes verificada, que compreendia problemas respiratórios, próprios de uma pneumonia, sintomas neurológicos e cardíacos.

Num primeiro momento, imaginou-se serem tais sintomas decorrentes de acidentes com armas bacteriológicas (supostamente ocorridos numa base militar norte-americana localizada em Torrejón de Ardoz, um dos locais onde a síndrome se manifestou) ou de intoxicação alimentar. Após a realização de pesquisas, apontou-se como fato comum a todas as vítimas e, consequentemente, causa da epidemia, o consumo de um óleo sem, contudo, que houvesse uma marca que permitisse a identificação de sua origem.

O óleo de colza é amplamente utilizado na Europa e destinado a consumo humano ou ao uso industrial. Na Espanha permitia-se, então, a importação do óleo, mas, como medida protetiva à produção óleoira local, restringia-se a sua utilização às indústrias. As normas administrativas espanholas determinavam, então, a adição de anilina, altamente tóxica ao consumo humano, dentre outros compostos químicos, ao óleo importado, como meio de garantir que não fosse destinado ao consumo humano. Essa norma, no entanto, não foi seguida adequadamente, pois os óleoiros não possuíam equipamento conveniente à adição da anilina e, sendo assim, não se processava modificação de cor, sabor e textura suficientemente significativa para distinguir o produto destinado à indústria daquele destinado ao consumo humano ${ }^{386}$.

A empresa familiar Refinería de Aceites de Pescado S.A. (RAPSA), que importava o óleo da França para fins industriais, se associa à empresa Raelca e, a partir daí, aumenta sua importação, apesar da crise industrial que havia na Espanha na época.

\footnotetext{
${ }^{385}$ MUÑOZ CONDE, Francisco; HASSEMER, Winfried. La responsabilidad por el producto en derecho penal, cit., p. 135.

${ }^{386}$ SARRABAYROUSE, Eugenio C. op. cit., p. 80.
} 
A RAPSA vendeu o óleo à Raelca que mandou refiná-lo nas empresas ITH e Danesa Blau e, em seguida, o destribuiu ao consumo humano, através de vendedores ambulantes. A Raelca também enviou o óleo para ser refinado na empresa Alabart que, após a eliminação da anilina, o revendeu a diversas empresas que, ignorando seu caráter tóxico, também o destinaram a consumo humano.

Como resultado do consumo do óleo tóxico, impróprio para consumo humano, trezentas e trinta pessoas morreram e quinze mil foram afetadas em sua integridade física.

Até hoje, a ciência não conseguiu estabelecer o mecanismo causal entre o princípio ativo contido no óleo e os danos físicos causados aos consumidores.

Trinta e oito pessoas que integravam a linha de produção ou comercialização do óleo foram acusadas pelo Ministério Público, tendo sido condenadas em primeira instância, em maio de 1989, apenas treze pela autoria ou participação nos crimes de burla e contra a saúde pública pela adulteração e comercialização do óleo. Cada um deles recebeu uma pena de prisão, multa e indenização às vítimas além do pagamento das custas do processo $^{387}$.

A mais importante condenação foi a de Juan Miguel Bengoechea Calvo, sócio da RAPSA, que, em seu recurso, alegou questões referentes ao nexo de causalidade e ao dolo que lhe foi imputado. Como dito anteriormente, não se chegou a estabelecer, cientificamente, qual específico princípio ativo capaz de causar os sintomas da chamada síndrome do óleo. Não foi encontrado no óleo, de acordo com os peritos, níveis significativos de toxinas conhecidas. Em relação ao dolo, a defesa alegou não ter autor como conhecer o caráter lesivo do óleo adulterado, fato que nem sequer através de experimentos científicos se conseguiu estabelecer, sendo, portanto, impossível se falar em dolo ainda que eventual.

No que se refere ao estabelecimento da relação de causalidade, a sentença do Tribunal Supremo espanhol lembrou diversos pontos das decisões proferidas pela Justiça alemã no caso Contergan e Lederspray e destacou que, além de descartar a possibilidade da realização do resultado por outras causas ${ }^{388}$, o nexo causal que precisava ser comprovado era somente o existente entre o consumo do óleo adulterado e a síndrome tóxica, sendo

\footnotetext{
${ }^{387}$ SARRABAYROUSE, Eugenio C. op. cit., p. 80.

${ }^{388} \mathrm{~A}$ defesa não conseguiu estabelecer qualquer causa diversa capaz de justificar o evento. Id. Ibid., p. 88.
} 
despicienda a especificação do princípio ativo causador dos $\operatorname{sintomas}^{389}$. O Tribunal esclareceu que todas as pessoas vitimadas pela síndrome haviam ingerido o óleo.

No que se refere à alegação de ausência de dolo na conduta de Bengoechea Calvo por desconhecimento do caráter tóxico da anilina presente no óleo, o Tribunal entendeu não corresponder à realidade, pois a toxidade da anilina era conhecida por todos os comerciantes que lidavam com o óleo, fossem eles empresários ou técnicos. O acusado, deste modo, era capaz de prever que, ao repassar o óleo adulterado a um comerciante que, habitualmente, destina suas mercadorias ao consumo humano, este acabaria sendo ingerido pelas pessoas, podendo causar, em consequência, lesão corporal e, até mesmo, a morte daqueles que o consumissem. Não restavam dúvidas, portanto, da presença de dolo, ao menos eventual, em relação aos resultados lesão corporal e morte ${ }^{390}$. Para o estabelecimento do dolo era desnecessário o conhecimento técnico da causalidade e de seu exato desenrolar. Bastava a consciência da presença da anilina e de seu caráter venenoso, impróprio ao consumo humano. E esses dois fatos eram sabidos pelo autor.

\subsubsection{Caso "Aqua dots"}

Produzido no Canadá e exportado para diversos países, inclusive para o Brasil, em 2007, este brinquedo era formado por várias pequeníssimas esferas coloridas que eram depositadas em cima de um molde e que deveriam ser, posteriormente, molhadas com o uso de um borrifador para que grudassem umas às outras formando pequenos decalques. Ocorre que, ao serem atingidas pela água, ocorria uma reação química para que elas se tornassem aderentes. Porém, para adquirir a propriedade de se unirem às outras, as esferas que deveriam liberar uma substância atóxica, liberavam ácido gama-hidroxibutírico, o GHB (também conhecido como ecstasy líquido), ou seja, uma droga comumente utilizada para a prática de crimes por causa de seus efeitos ${ }^{391}$.

Como consequência, o U.S. Consumer Product Safety Commission, que é uma comissão norte-americana encarregada de proteger o público contra graves riscos de morte

\footnotetext{
${ }^{389}$ SARRABAYROUSE, Eugenio C. op. cit., p. 86.

${ }^{390}$ Id. Ibid., p. 89.

${ }^{391}$ O GHB é uma conhecida rape drug, ou seja, uma droga utilizada para a prática de crimes sexuais (dentre os quais o "Boa noite, Cinderela") devido a seus efeitos que vão de desinibição e sensação de bem estar a sedação, desmaio, coma, podendo, inclusive, levar à morte súbita por parada cárdio-respiratória.
} 
e lesão corporal causadas por produtos, recebeu a denúncia a respeito de diversos incidentes decorrentes da intoxicação com o referido elemento. Houve o relato de que algumas crianças, após a ingestão das esferas entraram em um período de alguns dias em coma após diversos episódios de náuseas seguidos de vômito.

O produto que era recomendado para crianças a partir de quatro anos, liberava o GHB não apenas com o borrifo de água, mas, também, com o simples contato com o suor das crianças, aumentando, assim, ainda mais, seu potencial nocivo. Apesar da faixa etária para a qual havia sido recomendado, o produto causou lesões em crianças abaixo dos quatro anos.

A Spin Master, empresa sediada em Toronto no Canadá, fabricante e distribuidora do brinquedo, produziu quatro milhões e duzentas mil unidades do brinquedo. No Brasil o produto foi vendido com o nome comercial "Bindeez", pela empresa importadora e distribuidora Long Jump, que o vendeu para todo o país, tornando-se o grande sucesso de vendas da categoria naquele ano.

O produto foi alvo de recall em diversos países, dentre os quais, Austrália, Estados Unidos e Canadá. Nos Estados Unidos o comunicado sobre o recall foi lançado dia 07 de novembro de 2007.

No Brasil, os diretores da empresa importadora mesmo após a deflagração do recall em diversos países, declararam que iriam avaliar se houve problemas com a certificação do produto. Ocorre que numa situação em que já tenha havido inúmeros relatos a respeito da lesividade de um produto, ainda que tais relatos sejam sobre fatos acontecidos em outros países, o produto deve ser imediatamente retirado do mercado de consumo, ainda que as agências reguladoras não tenham determinado esta retirada.

No dia 08 de novembro o Pró Teste (Associação Brasileira de Defesa do Consumidor) notificou o Inmetro (Instituto Nacional de Metrologia, Normalização e Qualidade Industrial), o DPDC (Departamento de Proteção e Defesa do Consumidor) e a importadora Long Jump para que fosse realizado imediatamente o recall da linha de brinquedos Bindeez.

O recall foi comunicado pela empresa nos seguintes termos:

A Long Jump, empresa nacional do segmento de brinquedos, comunica a retirada da linha Bindeez do mercado, por meio de um recall preventivo. As "bolinhas" do produto podem conter substâncias tóxicas e causar danos à saúde, se acidentalmente ingeridos. Por este motivo, o brinquedo 
deve ser mantido fora do alcance das crianças. Entretanto, até o presente momento, não há confirmação se as unidades do produto comercializadas no Brasil contêm tais substâncias. O brinquedo foi enviado para repetição de testes e, nos próximos dias, a Long Jump receberá o laudo com a perícia técnica.

Considerando que o produto comercializado no Brasil é o mesmo que foi enviado para o resto do mundo, uma vez que o defeito dizia respeito à sua concepção, desnecessária e irresponsável é a declaração de que "não há confirmação se as unidades do produto comercializadas no Brasil contêm tais substâncias".

É de se observar, ainda, que o referido recall só foi comunicado pela empresa no dia 14 de novembro, deixando o produto por uma semana no mercado de consumo. Esta postura comercial não causa estranhamento, já que o Aqua dots foi o maior sucesso de vendas no Dia da Criança daquele ano, repetindo o sucesso que havia conseguido em todo o mundo. Desta forma, com a opção da empresa pela manutenção do brinquedo no mercado de consumo, fica clara a postura no sentido de assumir os riscos da produção de eventuais resultados lesivos.

Neste cenário a responsabilidade dos diretores da empresa importadora pelos eventos lesivos ocorridos após o conhecimento internacional do risco causado a crianças pelo contato com o produto é inconteste.

Conforme os modelos propostos, a conduta daqueles que, dentro da empresa importadora, tinham a capacidade de decidir pela retirada do produto do mercado de consumo, subsume-se àquela descrita pelo art. 63-C: "Oferecer, de qualquer modo, a consumo produto que saiba ou deveria saber expor a perigo a vida, a saúde ou a integridade física do consumidor”.

O engenheiro químico, responsável pelo projeto de produção de um brinquedo que, pelo tamanho da indústria, atingirá um número bastante expressivo de consumidores ao redor do mundo ${ }^{392}$, não pode ignorar o fato de que a adição de $\mathrm{H}_{2} \mathrm{O}$ a este brinquedo possa deflagrar a produção de droga tão potente. Se o produto tivesse sido produzido no Brasil, os técnicos responsáveis pela sua formulação, conforme os tipos propostos, responderiam pelo crime previsto no art. 63-A. “Abonar, no desempenho de função para a qual seja, ou

\footnotetext{
${ }^{392}$ De acordo com a U.S. Consumer Product Safety Commission, foram produzidas 4,2 milhões de unidades do brinquedo Aqua Dots pela indústria canadense Spin Master. In: US CONSUMER PRODUCT SAFETY COMMISSION. Crib Information Center. Disponível em: <http://www.cpsc.gov/info/cribs/index.html>. Acesso em: 08 ago. 2007.
} 
deveria ser, profissionalmente qualificado, produto destinado a consumo, que sabe ou deveria saber, em razão de seu conhecimento técnico ou científico, expor a perigo a vida, a saúde ou a integridade física do consumidor”.

\subsubsection{Caso "Fox"}

A partir de 2003, a Volkswagen colocou no mercado alguns modelos do automóvel FOX que apresentavam para o usuário a vantagem de poderem ter seus porta-malas ampliados através de um mecanismo de rebatimento do banco traseiro. No porta-malas havia uma argola metálica e, presa a ela, uma fita que, segundo o manual, deveria ser puxada para que o banco traseiro reclinasse. Ocorre que, alguns consumidores encaixaram o dedo na argola ao invés de puxar a fita, fato que fez com que uma mola fosse destravada e, em consequência, o dedo do consumidor fosse amputado. A Volkswagen, em sua defesa, alegou que havia previsto o perigo para o consumidor e, por isso, advertiu quanto a isso em seu manual. Entretanto, nos modelos exportados para a Europa, alega ter adotado outra solução técnica para o acionamento do mecanismo de ampliação do porta-malas.

Tais fatos foram amplamente divulgados pela imprensa e pelo Ministério da Justiça $^{393}$ que determinou o recall ${ }^{394}$, ainda que tardiamente, de quatrocentas e quarenta e sete mil unidades do automóvel.

Verifica-se, portanto, que a empresa tinha a perfeita consciência do perigo ao qual estaria submetendo seus consumidores caso colocasse o automóvel no mercado naquelas condições e, ainda assim, tomou a decisão de arriscar, apenas fazendo um alerta no manual.

Se a empresa tinha a consciência do risco (o que é evidenciado pela colocação do alerta no manual bem como pela adoção de solução técnica diversa para as unidades

\footnotetext{
${ }^{393}$ Segundo o Instituto Brasileiro de Defesa do Consumidor (IDEC), o Departamento de Proteção e Defesa do Consumidor (DPDC) do Ministério da Justiça divulgou no dia 02 de abril de 2008 a determinação de recall para as quatrocentas e quarenta e sete mil unidades vendidas até então desde 2003. O recall tem como objeto a adaptação do mecanismo de rebatimento do banco traseiro. Informação em INSTITUTO BRASILEIRO DE DEFESA DO CONSUMIDOR - IDEC. Disponível em: <www.idec.org.br>. Acesso em: 14 abr. 2008..

${ }^{394}$ Segundo o site da Volkswagen, "para aperfeiçoar o mecanismo de rebatimento do banco traseiro, serão adicionados componentes nos modelos com banco traseiro de encosto inteiriço e corrediço (ajuste longitudinal). Também serão fixadas novas etiquetas de orientação e advertência em quatro pontos do banco".
} 
exportadas para a Europa, onde a responsabilidade civil é mais dispendiosa), esta noção foi trazida pela equipe técnica (agentes de decisão) e não pelos Diretores que não necessariamente entendem de engenharia de produto.

Informados do risco, tomaram a decisão de colocar o automóvel no mercado naquelas condições e apenas alertar os consumidores no manual, ao invés de optarem pela adoção da mesma solução técnica pensada para o continente europeu. Uma vez que isso tudo ocorreu no âmbito empresarial, constata-se que tal decisão teve como fundamento o lucro, razão de ser de qualquer sociedade empresária.

Uma vez realizado o resultado lesão corporal grave, seria correto afirmar que há a nexo de causalidade entre ele e a decisão do órgão de direção da empresa de colocar o produto perigoso no mercado, mesmo consciente do risco. Devem, portanto, responder pelo resultado todos aqueles que participaram da tomada de decisão (tomadores de decisão ou decisores).

Nunca é demais lembrar que todo produto traz, em si, um risco a ele agregado.

Conforme MIGUEL REALE JÚNIOR: "Certas ações trazem ínsito ao seu desenrolar a potencialidade de dano, mas é admitida a sua realização pela sociedade, reconhecida sua validade para o tráfego social, constituindo-se um risco permitido, socialmente adequado",395.

No caso do automóvel, todo consumidor sabe que há a o risco - por razões diversas e alheias ao objeto do presente trabalho - de lesão corporal ou morte em decorrência de seu uso. E toda a sociedade está disposta a arcar com tal risco, uma vez que (quase) ninguém abriria mão do conforto trazido pela indústria automobilística. Porém, nenhum consumidor assume o risco de ter seu dedo amputado em decorrência do uso ou manuseio de seu automóvel. É, portanto, absurda e infundada a alegação da empresa de que as vítimas manusearam de forma errada o automóvel sendo, por isso, os únicos responsáveis pela lesão.

Um consumidor ao manusear qualquer parte de seu automóvel, não tem como imaginar que haverá um mecanismo de guilhotina capaz de proceder à amputação de seu dedo. Até porque, confia que uma indústria respeitada mundialmente não o colocaria diante de uma situação de risco proibido como esta.

\footnotetext{
${ }^{395}$ REALE JÚNIOR, Miguel. Instituições de direito penal: parte geral, 3. ed., cit., p. 237.
} 
Não há alerta suficiente em manual ou em qualquer lugar do próprio automóvel, capaz de afastar a responsabilidade daqueles que decidiram colocar no mercado um produto com risco tão diverso de seu risco inerente.

De acordo com o art. $8^{\circ}$ do Código de Defesa do Consumidor, os produtos e serviços colocados no mercado de consumo não acarretarão riscos à saúde ou segurança dos consumidores, exceto os considerados normais e previsíveis em decorrência de sua natureza e fruição, obrigando-se os fornecedores, em qualquer hipótese, a dar as informações necessárias e adequadas a seu respeito.

Neste caso, as lesões corporais decorrentes de acidente com o mecanismo de rebatimento do banco traseiro, podem gerar as seguintes tipificações, conforme os tipos propostos:

1) A conduta do engenheiro que aprova um projeto com o defeito de concepção descrito:

Art. 63-A. Abonar, no desempenho de função para a qual seja, ou deveria ser, profissionalmente qualificado, produto destinado a consumo, que sabe ou deveria saber, em razão de seu conhecimento técnico ou científico, expor a perigo a vida, a saúde ou a integridade física do consumidor.

2) Conduta dos diretores e outros membros dos órgãos da empresa com capacidade de tomar a decisão de disponibilizar o carro ao consumo apesar do conhecimento do potencial lesivo:

Art. 63-B. Decidir, no desempenho de função, ainda que por voto proferido em órgão colegiado, pela colocação ou manutenção no mercado de consumo, de produto que saiba ou deveria saber, em decorrência do exercício de sua função, expor a perigo a vida, a saúde ou a integridade física do consumidor.

3) Qualificação pelo resultado:

Art. 63-D. Nos crimes dolosos previstos nos artigos 63-A, 63-B e 63-C, as penas serão aumentadas:

II - da metade a dois terços, se, do uso ou consumo do produto resulta lesão corporal de natureza grave em outrem. 
A responsabilidade pode ser de ambas as esferas decisórias, diretores e técnicos, ou apenas de uma delas. A responsabilidade dos diretores responsáveis pela liberação do veículo ao mercado de consumo é clara, uma vez que consta do manual o alerta de perigo, ele não tem como alegar sua ignorância. A do técnico pode não existir, se ele tiver informado ao diretor da existência do risco e aconselhado pela não comercialização naquelas condições, por exemplo, estaria isento da responsabilidade. Mas, a verificação efetiva depende de uma série de fatores que demandariam uma ampla investigação de todos os fatos ocorridos no processo de fabricação para que pudessem ser individualizadas as condutas ocorridas em seu decurso.

\subsubsection{Caso "Microvlar"}

O anticoncepcional Microvlar, produzido à base dos hormônios femininos progesterona e estrógeno, começou a ser comercializado no Brasil em 1985 e logo se tornou o mais popular contraceptivo no mercado nacional, sendo o terceiro medicamento mais vendido no país ${ }^{396}$. Nos anos noventa, manteve sua posição comercial.

No dia 20 de maio de 1998, a Schering do Brasil, subsidiaria do Laboratório multinacional Schering $\mathrm{AG}$, com sede na Alemanha, responsável pela fabricação do medicamento, recebe uma cartela do contraceptivo acompanhada de uma carta anônima que advertia sobre a adulteração de sua composição química. A carta dizia que o medicamento havia sido comprado em Mauá, na periferia de São Paulo.

Uma semana depois a Schering já sabia que as pílulas continham uma massa inócua, feita de lactose e açúcar, sem os hormônios que deveria conter. A empresa prefere nada comunicar à população.

No mês de junho, três consumidoras de Mauá informam a indústria que engravidaram consumindo o anticoncepcional.

Além da ANVISA determinar que nesses casos a indústria deve notificá-la imediatamente, o Código de Defesa do Consumidor em seu artigo $6^{\circ}$, III, declara como direito básico do consumidor "a informação adequada e clara sobre os diferentes produtos

ICMS no celular. Liminar suspende cobrança. Online Consumidor S.A. Disponível em: <http://www.idec.org.br/consumidorsa/arquivo/out98/3506.htm>. Acesso em: 06 jul. 2010. 
e serviços, com especificação correta de quantidade, características, composição, qualidade e preço, bem como sobre os riscos que apresentem". Em seu artigo $8^{\circ}$ determina que:

Os produtos e serviços colocados no mercado de consumo não acarretarão riscos à saúde ou segurança dos consumidores, exceto os considerados normais e previsíveis em decorrência de sua natureza e fruição, obrigando-se os fornecedores, em qualquer hipótese, a dar as informações necessárias e adequadas a seu respeito.

Apesar disso, a Schering prefere se omitir e não alertar as consumidoras do produto acerca da possibilidade de engravidarem mesmo consumindo o contraceptivo até que o caso chegue ao conhecimento da imprensa, em 19 de junho. Somente depois disso, a Schering notifica a Vigilância Sanitária e comunica as autoridades policiais que havia tido um lote de Microvlar furtado.

Aos consumidores, a indústria emite um comunicado, "Ocorrências com o Microvlar" no qual informa os números das embalagens do medicamento que estavam equivocadamente disponibilizadas ao consumo. Mas não declara o real problema ocorrido. Omite-se em alertar às mulheres sobre o uso de outros métodos contraceptivos simultaneamente ao uso do Microvlar, bem como, a assistir às mulheres que ficaram grávidas em decorrência da inocuidade do medicamento que, em condições normais, apresenta eficácia de noventa e oito por cento.

A Schering levou mais de um mês para informar ao consumidor aquilo que já sabia.

De junho a agosto de 1998, a comercialização do Microvlar e suspensa pela Vigilância Sanitária que condiciona seu restabelecimento a mudanças na embalagem para que não houvesse a possibilidade da continuidade do consumo dos medicamentos adulterados.

A empresa alega, sem provas, que houve desvio das pílulas que eram, na verdade, placebo de farinha e foram usadas para testar em novo equipamento para embalagens e que essas pílulas foram, então, desviadas ao mercado de consumo.

As cartelas do placebo, assim como as embalagens, eram idênticas às dos comprimidos regulares, inclusive, no que diz respeito à presença de bula, tornando patente a negligência da empresa no que concerne à fiscalização de tais comprimidos. 
O equipamento em questão, da marca alemã Ullmann, comprado pela empresa pelo valor de três milhões de dólares capaz de produzir quatrocentas cartelas por minuto, embalou 1,2 toneladas do composto de lactose e açúcar entre os meses de janeiro e abril ${ }^{397}$.

As "pílulas de farinha", como ficaram conhecidas, foram vendidas legalmente em farmácias que possuíam, inclusive, as notas fiscais oriundas de grandes empresas distribuidoras de medicamentos.

Ao final do inquérito policial, chega-se a suspeita de que funcionários da empresa farmacêutica ou de uma empresa terceirizada de segurança haviam furtado os comprimidos.

Diversas vítimas da pílula de farinha que engravidaram apesar do uso cuidadoso de contraceptivo $^{398}$, ingressaram com ações na Justiça visando reparação civil. Uma delas recebeu a seguinte sentença: "pagamento de 3.100 salários mínimos de danos materiais e estéticos para a requerente, mais uma pensão mensal para o recém nascido de 25 salários mínimos até completar 21 anos de idade, garantindo uma qualidade de vida igual a um cidadão nascido na Alemanha, sede do laboratório"

A negligência de uma empresa multinacional da dimensão da Schering é, neste caso, inadmissível e merece reparação através do Direito, sem sombra de dúvidas. Mas, aqui, não há que se falar em reparação penal, pois, a consequência da irresponsabilidade dos diretores e funcionários da empresa não gerou lesão ou perigo de lesão a qualquer bem jurídico penalmente tutelado, mas o nascimento de crianças. A conduta é atípica. Não há, portanto que se falar em prática de crime, independe da atuação de qualquer um dos atores presentes na cadeia empresarial.

Não cabe ao Direito Penal tal tutela, sendo a civil, suficiente.

Ainda assim, o diretor-presidente e o farmacêutico e diretor industrial da Schering do Brasil, ambos representantes legais da empresa, foram condenados pelo crime previsto no artigo 63, combinado com o artigo 76, incisos II e V, da Lei 8.078/90 ${ }^{399}$ :

\footnotetext{
${ }^{397}$ Dados extraídos de GÁSPARI, Élio. A Schering pode virar farinha. Jornal do Commercio, Recife, 28 de junho de 1998. Disponível em: <http://www2.uol.com.br/JC/_1998/2806/ega2806.htm>. Acesso em: 06 jul. 2010.

${ }^{398}$ Apenas no Estado de Goiás, mais de vinte mulheres engravidaram em decorrência do uso do Microvlar adulterado.

${ }^{399} \mathrm{CDC}$, art. 63. Omitir dizeres ou sinais ostensivos sobre a nocividade ou periculosidade de produtos, nas embalagens, nos invólucros, recipientes ou publicidade; art. 76. São circunstâncias agravantes dos crimes tipificados neste código: II - ocasionarem grave dano individual ou coletivo; V - serem praticados em operações que envolvam alimentos, medicamentos ou quaisquer outros produtos ou serviços essenciais.
} 
Após reformada, a condenação se restringiu ao artigo $63 \S 2^{\circ}$, que prevê a modalidade culposa do delito.

Absurda é a ideia de que as embalagens dos medicamentos deveriam apresentar alertas sobre a periculosidade do produto, já que, por óbvio, o laboratório não advertiria a população sobre o fato de um medicamento ser inócuo. A defesa alega, em habeas corpus $^{400}$ impetrado perante o Superior Tribunal de Justiça que "se o'produto' vai ser destruído e não comercialmente distribuído para consumo, o dever de advertir o consumidor não aparece. E nestas condições não há justa causa para punir os diretores da empresa pela omissão de algo que não era exigível".

O caso das "pílulas de farinha" da Schering foi um dos mais graves casos de desrespeito ao consumidor ocorridos no Brasil. Que houve negligência por parte da empresa é fato inconteste, e digno de volumosa reparação civil. Mas da negligência da referida indústria farmacêutica não decorreu lesão nem perigo de lesão a bem jurídicopenal, sendo desnecessária e apenas simbólica ${ }^{401}$ a aplicação do Direito Penal a este caso.

Caso diverso ocorreria se, ao invés de se usar pílulas contraceptivas para a testagem do novo equipamento de embalagem, a indústria tivesse utilizado pílulas de medicamentos contra doenças, especialmente, contra doenças letais. Neste caso, a vida dos consumidores restaria em perigo incontestável e os responsáveis pela negligência mereceriam a responsabilização penal por seus atos.

É de se notar, no entanto, que essas pessoas não seriam, necessariamente, os responsáveis legais pela empresa, sob o risco de se imputar objetivamente a responsabilidade penal a eles. Seriam, por exemplo, aqueles funcionários que tivessem descumprido o seu dever de cuidado no que diz respeito ao descarte dos placebos, bem como, aquele responsável por essa fiscalização.

\footnotetext{
${ }^{400}$ SUPERIOR TRIBUNAL DE JUSTIÇA. Disponível em: <https://ww2.stj.jus.br/websecstj/decisoesmonocraticas/frame.asp?url=/websecstj/cgi/ revista/REJ.cgi/MON?seq=502235\&formato=PDF>. Acesso em: 06 jul. 2010.

${ }^{401}$ HASSEMER, Winfried. Derecho penal simbólico y protección de bienes jurídicos, cit.
} 


\section{CONCLUSÃO}

Em sua atual configuração, a sociedade impõe novas demandas ao controle social. Os chamados novos riscos, trazidos pela evolução tecnológica como efeitos colaterais, associados à insuficiência de outros ramos do ordenamento jurídico na tutela dos indivíduos e da sociedade diante dos novos conflitos trazem à tona a percepção da necessidade da intervenção, ultima ratio, do Direito Penal em espaços que antes não reclamavam sua interferência.

Os referidos efeitos colaterais trazidos por essa fase da modernidade, chamada por ULRICH BECK de reflexiva, unidos aos movimentos de integração econômica têm a capacidade de levar as implicações daquilo que é decidido no Brasil, no âmbito de uma sociedade empresária, ao outro lado do mundo, gerando consequências, muitas vezes, imprevisíveis. A atuação pessoal na seara da empresa, assim como, as consequências que dela vierem a ocorrer, devem, sim, ser objeto de interesse do Direito Penal, uma vez que, podem trazer a elas agregadas um incomensurável potencial de perigo, além do previsível e juridicamente permitido, e de dano.

Ainda que haja a pertinência da tutela penal à sociedade e ao indivíduo frente às condutas indesejadas praticadas por aqueles que atuam ao longo da cadeia empresarial, é necessário que sejam estabelecidos claros e precisos limites à interferência desta que é a resposta mais firme que pode ser atribuída pelo Estado ao indivíduo no exercício do controle social. Neste cenário a necessidade à limitação do jus puniendi torna-se ainda mais premente visto que há uma forte tendência a que se acabe responsabilizando penalmente um indivíduo que ou não tenha a efetiva responsabilidade sobre a causa geradora do resultado indesejado ou, ainda, que não possua a capacidade de controlar a sobredita causa, em decorrência de inúmeros fatores, dentre os quais, a própria natureza humana, limitadora fática da atuação individual. A mera imposição do perigo pela atuação ao longo da cadeia empresarial, como consequência de sua potencialidade, já é digna de tutela penal, sendo certo que, para que seja justificada a antecipação do resultado delitivo, deverá haver, também neste ponto, a observação de rígidos limites à atuação do poder punitivo do Estado.

Neste sentido, naquilo que diz respeito à proteção ao consumidor diante dos riscos e, até mesmo, danos a ele impostos pela fabricação e comercialização de produtos 
defeituosos, a teoria do bem jurídico mostra-se como primeira baliza a ser observada para que não sejam produzidos tipos penais meramente simbólicos nem para que a atuação do indivíduo na sociedade seja limitada injustificadamente. A análise criteriosa da referida teoria associada à observação dos princípios penais da fragmentariedade e subsidiariedade apontam o consumidor como objeto de proteção da Lei $n^{\circ}$. 8078/90 e os bens jurídicos saúde, vida e integridade física como aqueles efetivamente merecedores da tutela penal, sendo as tutelas civil e administrativa suficientes para a resposta estatal frente à colocação em perigo ou ao dano à propriedade.

Diante desta fase em que a economia conta com um cenário de produção, comercialização e consumo em massa, é de se observar e ressaltar a posição protagonista das relações de consumo como fonte de conflitos sociais e jurídicos. A integração de diversos mercados, seja nacional ou internacionalmente, também pode ser entendida como importante fator para que haja o substancial aumento da ocorrência dos conflitos, que restam, muitas vezes, sem solução em decorrência do seu não ou inadequado enfrentamento pelo Poder Judiciário.

Levando-se em conta sua vulnerabilidade na esfera da relação consumerista, o consumidor, neste panorama, deve ser entendido de forma ampla, ou seja, naquilo que interessa ao presente trabalho, toda e qualquer pessoa que tenha contato, direto ou indireto, com o produto fornecido. O fornecedor, neste sentido, ao fabricar ou comercializar um produto deve observar, rigidamente, os direitos básicos do consumidor, previstos no art. $6^{\circ}$ da Lei $n^{\circ}$. 8.078/90 (CDC), notadamente, naquilo que se refere (I) à proteção da vida, da saúde e da segurança do consumidor contra os riscos provocados por práticas no fornecimento de produtos considerados perigosos ou nocivos.

O produto, deste modo considerado qualquer bem, móvel ou imóvel, material ou imaterial, (CDC, art. $\left.3^{\circ} \S 1\right)$, deve atender a legítima expectativa de segurança do consumidor que deverá ser devidamente informado a respeito de suas características pelo fornecedor, inclusive, quando sobrevier, após a comercialização, periculosidade ou nocividade anteriormente desconhecida. Em alguns casos, inclusive, o produto deverá ser retirado do mercado de consumo (recall) pelo fornecedor, ainda que a retirada não seja determinada pelo poder público, uma vez que, consoante o art. $13 \S 2^{\circ}$ do Código Penal, o dever de agir incumbe a quem, dentre outros fatores, (c) com seu comportamento anterior, criou o risco da ocorrência do resultado. 
Ressalte-se que tanto o produto quanto o risco que ele impõe ao consumidor, assim como, as respostas a eles, devem ser encarados, conforme a espécie de periculosidade que venha a apresentar. A periculosidade pode ser inerente ao próprio produto ( neste caso, só se pode falar em defeito de informação); exagerada ou adquirida em decorrência de defeito de concepção, fabricação ou comercialização. Cada uma dessas modalidades de defeito deve receber um diferente tratamento, seja naquilo que diz respeito à providência devida para a evitação de que o perigo seja concretizado, lesando os bens jurídicos do consumidor; seja na resposta dada ao agente causador do defeito pelo Direito e, especialmente, pelo Direito Penal.

No Brasil, há uma série de órgãos e diplomas normativos que procuram tutelar, direta ou reflexamente, os direitos básicos do consumidor, dentre os quais citam-se o Ministério da Saúde, a Anvisa, o Inmetro, além das Leis nº 8.078/90, 8.137/90 e o Código Penal. No entanto, é patente a insuficiência dos referidos instrumentos. Exemplo que se ressalta é a Anvisa que falha ao avaliar um processo de solicitação de registro, limitando-se à análise de documentação por parte da empresa solicitante, dispensando a realização de testes científicos que, apenas serão feitos em caso de suspeita de irregularidades no produto, ou seja, posteriormente à sua colocação no mercado de consumo e consequente imposição de risco ao consumidor. Em relação aos diplomas legais, destaca-se a ausência no microssistema consumerista, de norma específica para tutelar o consumidor diante da fabricação e comercialização de produtos que o exponha a perigo. Numa lei em que o produto é conceituado de forma ampla, é de se estranhar a ausência de regra capaz de desestimular o fornecedor de eventual prática abusiva de imposição de riscos além do permitido ao consumidor por meio da fabricação ou comercialização de produto. O Código Penal chega a tipificar em alguns dispositivos as condutas relativas a disponibilização de produtos no mercado de consumo, podendo o ordenamento jurídico-penal brasileiro chegar a considerar como hediondas determinadas condutas que, mesmo neste cenário, podem apresentar total ausência de periculosidade ou nocividade (caso da comercialização de cosméticos sem o registro no órgão devido). No entanto, restringe-se ao tratamento de determinados e específicos produtos, como alimentos, bebidas e medicamentos (cosméticos, saneantes...), ignorando, deste modo, o perigo causado por diversos outros, como móveis (berços, p. ex.), brinquedos, automóveis etc. 
Mas não é apenas esta lacuna no ordenamento jurídico que traz dificuldades à tutela penal do consumidor diante dos perigos eventualmente causados por produtos. Ainda mais complicada é a responsabilização penal que deve ser imputada apenas a quem tenha dado causa dolosa ou culposamente ao resultado proibido. Sendo descabida a hipótese de responsabilidade penal da pessoa jurídica, é necessário que seja aferida a quem coube a atuação responsável por agregar defeito ao produto e se tal atuação foi dolosa ou, ao menos, culposa. É, de qualquer modo, imperativo que a responsabilidade penal, ainda que aferida no cenário da sociedade empresária, seja sempre subjetivamente considerada, sob pena de inconstitucionalidade. Neste sentido, note-se, ainda, que, consideradas as esferas de responsabilidade no seio da empresa, as diversas atuações podem gerar responsabilidades concorrentes ou excludentes. Ou seja, haverá casos em que a responsabilidade por um resultado caberá a apenas um agente; em outros casos, caberá a mais de um; e, em algumas situações, a atuação de um agente acabará por desconstituir a importância da atuação de outro.

Para que se constitua a responsabilidade penal pelo produto faz-se necessário, num primeiro momento, que se verifique a existência de causalidade entre o resultado indesejado e o produto. Somente após estar estabelecida esta relação é que se deve seguir para a aferição da atuação responsável pelo potencial lesivo ou nocivo do produto.

O defeito do produto pode ser decorrente de atuação de um ou mais de um agente, dependendo de múltiplos fatores: qual o momento da gênese do defeito; quais pessoas são responsáveis por atuar nesse momento; a quem cabe, nesta fase, a tomada de decisão e se há a necessidade de informações técnicas para que se decida. Numa cadeia empresarial é de se notar além da capacidade de tomada de decisão em cada esfera de atuação, a presença de fatores tais como hierarquia e divisão de trabalho. Todos esses fatores devem ser analisados criteriosamente para que se chegue a quem foi pessoalmente responsável pelo defeito. E isso nem sempre é possível. Há casos em que não se percebe qualquer conduta que tenha sido aquela capaz de gerar o referido vício. Há, ainda, situações em que, mesmo diante de atuações absolutamente dentro dos parâmetros legais e regulamentares, surgem produtos defeituosos. Neste caso, não há que se falar em dolo nem em culpa, excluindo-se, portanto, a responsabilidade penal. Cabe, porém, resposta ao prejuízo suportado pelo consumidor por meio de responsabilidade civil. 
É de se notar que a verificação da responsabilidade penal no âmbito da sociedade empresária deve receber tratamento diverso conforme a estrutura da dita sociedade seja mais ou menos complexa, devido, especialmente, às responsabilidades assumidas legal ou estatutariamente, pelos atores no seio da cadeia empresarial, bem como, pela sua real possibilidade de atuação.

Em relação ao estabelecimento da causalidade diversas dificuldades são encontradas, tendo sido desenvolvidas pela jurisprudência e doutrina alemãs alguns parâmetros de verificação.

Naquilo que se refere à aferição da causalidade entre o produto e o resultado, podese chegar, por conta das limitações das ciências naturais nesta seara, à ausência de explicações científicas a respeito, por exemplo, no caso de medicamentos, de qual elemento químico exato, qual princípio ativo, foi capaz de causar o resultado lesivo. Sabese que é aquele produto o causador do dano, sabe-se que não há qualquer outra causa possível, mas, não se consegue pontuar a causa. Para estes casos, a jurisprudência alemã, criticada por parte da doutrina, apoiada por outra parte, criou aquilo que se passou chamar de Teoria da Causalidade Plausível ou da "Caixa Negra", segundo a qual, nestes casos, basta que haja a convicção do juiz acerca da causalidade para que se possa estabelecê-la.

Por outro lado, há a dificuldade de serem estabelecidas as responsabilidades por decisões tomadas em órgãos colegiados. Neste caso, a jurisprudência alemã entende que todos aqueles que votaram pelo atuação que gerou o defeito são penalmente responsáveis, ainda que seu voto tenha sido proferido após a formação de maioria. Basearam-se para tal construção na fórmula da causalidade cumulativa segundo a qual, condições independentes (no caso, cada voto) se unem para a produção de um determinado resultado. Neste caso, cada voto a favor aumentaria o risco da produção do resultado indesejado, sendo, por isso, punível, e cada voto contra, por outro lado, o diminuiria, não sendo, por isso, digno de punição.

Pode-se concluir que o Direito Penal brasileiro mostra-se, atualmente, incapaz de tutelar adequadamente o consumidor naquilo que se refere a possíveis riscos impostos por fornecedores por meio da produção e comercialização de produtos potencialmente lesivos à saúde, vida e integridade física, fazendo-se, deste modo, necessária a criação de novas normas que venham a preencher a referida lacuna. Neste sentido, foram propostos tipos penais destinados às condutas que, praticadas ao longo da cadeia de fabricação e comercialização de produtos, possam ter o condão ou de gerar o defeito no produto, ou de 
destinar ou manter o produto defeituoso no mercado de consumo. Para tanto propuseramse tipos destinados: a) a conduta dos técnicos e peritos, responsáveis pela elaboração e qualidade do produto; b) dos administradores e diretores, responsáveis pela tomada de decisão na cadeia empresarial; c) e dos comerciantes, responsáveis pela distribuição dos produtos no mercado de consumo, bem como, por sua conservação. Para todas as condutas foi proposta a qualificação pelo resultado lesão corporal e morte. 


\section{REFERÊNCIAS BIBLIOGRÁFICAS}

1961: Contergan é retirado do mercado. Disponível em:<http://www.dwworld.de/dw/article/ 0,,678470,00.html>. Acesso em: 15 jan. 2009.

1967: início do processo da Talidomida na Alemanha. Disponível em: <http://www.dwworld.de/dw/article/0,,351856,00.html>. Acesso em: 15 jan. 2009.

AMARAL, Cláudio do Prado. Bases teóricas da ciência penal contemporânea: dogmática, missão do direito penal e política criminal na sociedade de risco. São Paulo: IBCCRIM, 2007.

ANVISA. Disponível em: <http://www.anvisa.gov.br/inspecao/boas.htm>. Informe Técnico n. 44, de 22 de dezembro de 2010. Esclarecimentos das medidas adotadas sobre os produtos de marca "Divine Shen" e o insumo "Caralluma fimbriata". Disponível em: <http://portal.anvisa.gov.br/wps/wcm/connect/368c04004526602ba8d6f82475bf1155/Infor me+T\%C3\%A9cnico+Divine+Shen+e+Caralluma+fimbriata.pdf?MOD=AJPERES. Acesso em: 27 dez. 2010.

BATISTA, Nilo. Concurso de agentes: uma investigação sobre os problemas da autoria e da participação no direito penal brasileiro. 4. ed. Rio de Janeiro: Lumen Juris, 2008.

Introdução crítica ao direito penal brasileiro. 9. ed. Rio de Janeiro: Ed. Revan, 2004.

; ZAFFARONI, E. Raúl; ALAGIA, Alejandro; SLOKAR, Alejandro. Direito penal brasileiro: teoria geral do direito penal. 2. ed. Rio de Janeiro: Revan, 2003. v. 1.

BECCARIA, Cesare. Dos delitos e das penas. São Paulo: Martins Fontes, 1997.

BECK, Ulrich. A reinvenção da política: rumo a uma teoria da modernização reflexiva. In: ; GIDDENS, Anthony; LASH, Scott. Modernização reflexive: política, tradição e estética na ordem social moderna. São Paulo: Ed. da UNESP, 1997. 
BECK, Ulrich. La sociedad del riesgo: hacia una nueva modernidad. Traduzido por Jorge Navarro, Daniel Jimenez, Maria Rosa Borras. Barcelona: Paidós, 2006. (Colección Surcos).

BENJAMIN, Antônio Herman V.; MARQUES, Cláudia Lima; BESSA, Leonardo Roscoe. Manual de direito do consumidor. 2. ed. rev. atual. e ampl. São Paulo: Ed. Revista dos Tribunais, 2009.

BONAVIDES, Paulo. Curso de direito constitucional. São Paulo: Malheiros Ed., 2000.

BOTTINI, Pierpaolo Cruz. Crimes de perigo abstrato. 2. ed. rev. e atual. São Paulo: Ed. Revista dos Tribunais, 2010.

COELHO, Fábio Ulhoa. Curso de direito comercial: direito de empresa. 3. ed. São Paulo: Ed. Saraiva, 1999. v. 2.

O empresário e os direitos do consumidor: o cálculo empresarial na interpretação do Código de Defesa do Consumidor. São Paulo: Saraiva, 1994.

COMISSÃO DAS COMUNIDADES EUROPÉIAS. Livro Verde. A responsabilidade civil decorrente dos produtos defeituosos (apresentado pela Comissão) Bruxelas, 28.07.1999. COM(1999)396 final. Disponível em: <http://ec.europa.eu/enterprise/policies/singlemarket-goods/files/goods/docs/liability/1999-greenpaper/com1999-396_pt.pdf>.

COSTA JUNIOR, Paulo José da; COSTA, Fernando José da. Crimes contra o consumidor. 2. ed. São Paulo: Atlas, 2008.

CRONOLOGIA da crise da doença da vaca louca na Grã-Bretanha. BBC Brasil, 30 jan. 2001. Disponível em: <http://www.bbc.co.uk/portuguese/noticias/2001/010130_bsecronologia.shtml>.

DE LUCCA, Newton. Direito do consumidor. São Paulo: Quartier Latin, 2003.

DENARI, Zelmo. Da responsabilidade pelo fato do serviço. In: GRINOVER, Ada Pellegrini; BENJAMIN, Antônio Herman de Vasconcellos e; FINK, Daniel Roberto; FILOMENO, José Geraldo Brito; WATANABE, Kazuo; NERY JÚNIOR, Nelson; DENARI, Zelmo. Código brasileiro de defesa do consumidor comentado pelos autores do anteprojeto. 8. ed. Rio de Janeiro: Forense Universitária, 2004. 
DEPARTAMENTO DE POLÍCIA DE PROTEÇÃO À Cidadania (DPPC). Legislação e prática. São 2009 Paulo, Disponível em: <http://www.portalapas.org.br/imagens/destaques_home/091210/CARTILHA_DPPC.pdf>. Acesso em: 29 dez. 2009.

DIAS, Jorge de Figueiredo. Questões fundamentais do direito penal revisitadas. São Paulo: Ed. Revista dos Tribunais, 1999.

DOTTI, René Ariel. A incapacidade criminal da pessoa jurídica. In: PRADO, Luiz Regis; DOTTI, René Ariel. Responsabilidade penal da pessoa jurídica. 2. ed. rev. e atual. São Paulo: Ed. Revista dos Tribunais, 2010.

EUR-LEX. Directiva 85/374/CEE do Conselho, de 25 de Julho de 1985, relativa à aproximação das disposições legislativas, regulamentares e administrativas dos EstadosMembros em matéria de responsabilidade decorrente dos produtos defeituosos. Disponível em: $<$ http://eurlex.europa.eu/LexUriServ/LexUriServ.do?uri=CELEX:31985L0374:pt:HTML>. Acesso em: 19 set. 2008.

EUROPA. Europa Commission. Consumer Affairs. Disponível em: $<$ http://ec.europa.eu/consumers/ecc/index_en.htm>.

- Glossário $\quad-\quad$ Livros Verdes.. Disponível em: <http://europa.eu/scadplus/glossary/green_paper_pt.htm>.

FARALDO CABANA, Patricia. Posibilidades de aplicación de la autoría mediata con aparatos organizados de poder en la empresa. Disponível em: $<$ http://www.alfonsozambrano.com/>.

FEIJOO SÁNCHEZ, Bernardo. Cuestiones actuales de derecho penal econômico. Buenos Aires: Julio César Faira Ed., 2009.

FERNANDES, Paulo Silva. O direito penal no amanhecer do século XXI: breves questões à luz do paradigma da "sociedade de risco". Sub judice: justiça e sociedade, Lisboa, n. 19, p. 111-127, dez. 2001.

FERRAZ, Esther de Figueiredo. A co-delinquência no moderno direito penal brasileiro. São Paulo: José Bushatsky, 1976. 
FERREIRA, Ivette Senise. A tutela penal do meio ambiente. In: BENJAMIN, Antonio Herman V. (Coord.). Dano ambiental: prevenção, reparação e repressão. São Paulo: Revista dos Tribunais, 1993.

FILOMENO, José Geraldo Brito. Manual de direitos do consumidor. São Paulo: Atlas, 2001.

GÁSPARI, Élio. A Schering pode virar farinha. Jornal do Commercio, Recife, 28 de junho de 1998. Disponível em: <http://www2.uol.com.br/JC/_1998/2806/ega2806.htm>. Acesso em: 06 jul. 2010.

GIDDENS, Anthony. Risco, confiança, reflexividade. In: BECK, Ulrich; GIDDENS, Anthony; LASH, Scott. Modernização reflexiva: política, tradição e estética na ordem social moderna. São Paulo: Ed. da UNESP, 1997.

GOMES, Luiz Flavio Autran Monteiro. Teoria da decisão. São Paulo: Thomson, 2006. (Coleção debates em administração).

GRECO, Luís. Breves reflexões sobre os princípios da proteção de bens jurídicos e da subsidiariedade no direito penal. Revista Jurídica do Ministério Público de Mato Grosso, Cuiabá, v. 2, n. 3, p. 249-276, jul./dez. 2007.

_. Um panorama da teoria da imputação objetiva. Rio de Janeiro: Lumen Juris, 2005.

GRINOVER, Ada Pellegrini; BENJAMIN, Antônio Herman de Vasconcellos e; FINK, Daniel Roberto; FILOMENO, José Geraldo Brito; WATANABE, Kazuo; NERY JÚNIOR, Nelson; DENARI, Zelmo. Código brasileiro de defesa do consumidor comentado pelos autores do anteprojeto. 8. ed. Rio de Janeiro: Forense Universitária, 2004.

HASSEMER, Winfried. Derecho penal simbólico y protección de bienes jurídicos. In: BUSTOS, Juan Bustos Ramirez (Dir.). Pena y Estado. Santiago: Editorial Jurídica Conosur, 1995.

; MUÑOZ CONDE, Francisco. Introducción a la criminologia y al derecho penal. Valencia: Tirant lo Blanch, 1989. 
HIRSCH, Hans Joachim. Acerca del estado actual de la discusión sobre el concepto de bien jurídico. In: CONGRESO INTERNACIONAL. FACULTAD DE DERECHO DE LA UNED. Modernas tendencias en la ciencia del derecho penal y en la criminología. Madrid: Universidad Nacional de Educación a Distancia, 2001.

ICMS no celular. Liminar suspende cobrança. Online Consumidor S.A. Disponível em: <http://www.idec.org.br/consumidorsa/arquivo/out98/3506.htm>. Acesso em: 06 jul. 2010

INCERTEZAS fabricadas. Entrevista com o sociólogo alemão, Ulrich Beck. Disponível em:

$<$ http://amaivos.uol.com.br/amaivos09/noticia/noticia.asp?cod_noticia=7063\&cod_canal= 41>. Acesso em: 14 fev. 2010.

ÍNIGO CORROZA, Ma . Elena. La responsabilidad penal del fabricante por defectos de sus productos. Barcelona: J.M. Bosch, 2001.

INMETRO. $O$ que é $o$ Inmetro. Disponível em: <http://www.inmetro.gov.br/inmetro/oque.asp.>. Acesso em: 27 dez. 2010.

INSTITUTO BRASILEIRO DE DEFESA DO CONSUMIDOR - IDEC. Disponível em: <www.idec.org.br>. Acesso em: 14 abr. 2008.

JAKOBS, Günther. ¿Qué protege el derecho penal: bienes jurídicos o la vigencia de la norma? Mendoza: Ediciones Jurídicas Cuyo, 2008.

JAPIASSÚ, Hilton; MARCONDES, Danilo. Dicionário básico de filosofia. 4. ed. atual. Rio de Janeiro: Jorge Zahar, 2006.

JIMÉNEZ DE ASÚA, Luis. Tratado de derecho penal: el delito. 5. ed. Buenos Aires: Losada, 1965. t. 3.

KINDHÄUSER, Urs. Estructura e legitimación de los delitos de peligro del derecho penal. Revista para el Análisis del Derecho, Barcelona, 2009.

KUHLEN, Lothar. Cuestiones fundamentales de la responsabilidad penal por el producto. In: MIR PUIG, Santiago; LUZÓN PEÑA, Diego Manuel (Coords.). Responsabilidad penal de las empresas y sus órganos y responsabilidad por el producto. Barcelona: Bosch, 1996. 
LASH, Scott. A reflexividade e seus duplos: estrutura, estética e comunidade. In: BECK, Ulrich; GIDDENS, Anthony; LASH, Scott. Modernização reflexive: política, tradição e estética na ordem social moderna. São Paulo: Ed. da UNESP, 1997.

LOPEZ, Teresa Ancona. Princípio da precaução e evolução da responsabilidade civil. 2008. Tese (Titular de Direito Civil) - Faculdade de Direito, Universidade de São Paulo, São Paulo, 2008.

LUISI, Luis. Notas sobre a responsabilidade penal das pessoas jurídicas. In: PRADO, Luiz Regis; DOTTI, René Ariel. Responsabilidade penal da pessoa jurídica. 2. ed. rev. e atual. São Paulo: Ed. Revista dos Tribunais, 2010.

MARQUES, Cláudia Lima. O Código Brasileiro de Defesa do Consumidor e o MERCOSUL: estudos sobre a proteção do consumidor no Brasil e no MERCOSUL. Porto Alegre: Livr. do Advogado, 1994.

Contratos no Código de Defesa do Consumidor: o novo regime das relações contratuais. 5. ed. São Paulo: Ed. Revista dos Tribunais, 2005.

; BENJAMIN, Antônio Herman V.; MIRAGEM, Bruno. Comentários ao Código de Defesa do Consumidor. 3. ed. rev. atual. e ampl. São Paulo: Ed. Revista dos Tribunais, 2010.

MERCOSUL. XIX Reunião do Conselho do Mercado Comum. Declaração Presidencial dos Direitos Fundamentais dosm Consumidores do Mercosul. Disponível em: $<$ http://www2.mre.gov.br/xixmercosul/Textos/dec-direitosfund.htm>.

MUNÕZ CONDE, Francisco. Edmund Mezger e o direito penal de seu tempo: estudos sobre o direito penal no nacional-socialismo. Tradução de Paulo César Busato. 4. ed. Rio de Janeiro: Lumen Juris, 2005.

; HASSEMER, Winfried. La responsabilidad por el producto en derecho penal. Valencia: Tirant lo Blanch, 1995.

PRADO, Luiz Regis. Bem jurídico-penal e Constituição. 4. ed. São Paulo: Ed. Revista dos Tribunais, 2009. 
PRADO, Luiz Regis. Responsabilidade penal da pessoa jurídica: fundamentos e implicações. In: PRADO, Luiz Regis; DOTTI, René Ariel. Responsabilidade penal da pessoa jurídica. 2. ed. rev. e atual. São Paulo: Ed. Revista dos Tribunais, 2010.

; DOTTI, René Ariel. Responsabilidade penal da pessoa jurídica. 2. ed. rev. e atual. São Paulo: Ed. Revista dos Tribunais, 2010.

PUPPE, Ingeborg. Problemas de imputación del resultado en el ámbito de la responsabilidad penal por el producto. In: MIR PUIG, S; LUZÓN PEÑA, D. M. (Coords.). Responsabilidad penal de las empresas e sus órganos y responsabilidad por el producto. Barcelona: Jose Maria Bosch Editor, 1996. (Colección Biblioteca de Derecho Penal).

El resultado y su explicación causal en derecho penal. In: SANCINETTI, Marcelo A. (Comp.). Causalidade, riesgo e imputación: 100 años de contribuiciones críticas sobre imputación objetiva y subjetiva. Buenos Aires: Hammurabi, 2009.

REALE JÚNIOR, Miguel. A responsabilidade penal da pessoa jurídica. In: PRADO, Luiz Regis; DOTTI, René Ariel. Responsabilidade penal da pessoa jurídica. 2. ed. rev. e atual. São Paulo: Ed. Revista dos Tribunais, 2010.

Instituições de direito penal: parte geral. Rio de Janeiro: Forense, 2002. v. 1. Instituições de direito penal: parte geral. 3. ed. Rio de Janeiro: Forense, 2009. Teoria do delito. São Paulo: Ed. Revista dos Tribunais, 1998.

ROBERTSON, Roland. Globalization: time-space and homogeneity-heterogeneity. In: FEATHERSTONE, Mike; LASH, Scott; ROBERTSON, Roland. Global modernities. London: Sage, 1995. p. 25-44.

ROXIN, Claus. A autoría y dominio del hecho em derecho penal. Trad. Joaquín Cuello Contreras y José Luis Serrano González de Murillo. 7. ed. Madrid: Marcial Pons, 2000.

Derecho penal: parte general. Trad. da 2. ed. alemã: Diego-Manuel Luzón Pena, Miguel Diaz y Garcia e Javier de Vicente Remsal. Madrid: Civitas, 1997. t. 1, Fundamentos. La estructura de la teoria del delito.

A proteção de bens jurídicos como função do direito penal. Org. e trad. André Luís Callegari e Nereu José Giacomolli. 2. ed. Porto Alegre: Livraria do Advogado, 2009. 
ROXIN, Claus. Infracción del deber y resultado en los delitos imprudentes. Problemas básicos del derecho penal. Madri: Reus, 1976. p. 149-180.

SANSEVERINO, Paulo de Tarso Vieira. Responsabilidade civil no Código do Consumidor e a defesa do fornecedor. 3. ed. São Paulo: Saraiva, 2010.

SANTOS, Juarez Cirino dos. Responsabilidade penal da pessoa jurídica. In: PRADO, Luiz Regis; DOTTI, René Ariel. Responsabilidade penal da pessoa jurídica. 2. ed. rev. e atual. São Paulo: Ed. Revista dos Tribunais, 2010.

SARRABAYROUSE, Eugenio C. Responsabilidad penal por el producto. Buenos Aires: Ad-Hoc, 2007.

SCHÜNEMANN, Bernd. El llamado delito de omisión impropria o la comisión por omisión. In: GARCÍA VALDÉS, Carlos et al (Coord.). Estudios penales en homenaje a Enrique Gimbernat II. Madrid: Edisofer, 2008. t. 2, p. 1609-1630.

. Responsabilidad penal en el marco de la empresa: dificultades relativas a la individualización de la imputación. Anuario de derecho penal y ciencias penales. ; Boletín Oficial del Estado, Madrid: Ministerio de Justicia, t. 55, n. 1, p. 9-38, 2002.

SHECAIRA, Sérgio Salomão. Responsabilidade penal da pessoa jurídica. São Paulo: Ed. Revista dos Tribunais, 1998.

SILVA SÁNCHEZ, Jesus-María. A expansão do direito penal: aspectos da política criminal nas sociedades pós-industriais. Tradução de Luiz Otavio de Oliveira Rocha. São Paulo: Ed. Revista dos Tribunais, 2002. (Série as ciências criminais no século 21, v. 11).

SILVEIRA, Renato de Mello Jorge. Direito penal supra-individual. Interesses difusos. São Paulo: Ed. Revista dos Tribunais, 2003. (Série Ciência do Direito Penal contemporânea, v. 3).

SOUSA, Susana Aires de. Responsabilidade criminal por produtos defeituosos. Revista Brasileira de Ciências Criminais, São Paulo, v. 17. n. 76, p. 106-121, jan./fev. 2009.

SUPERIOR TRIBUNAL DE JUSTIÇA. Disponível em: <https://ww2.stj.jus.br/websecstj/decisoesmonocraticas/frame.asp?url=/websecstj/cgi/ revista/REJ.cgi/MON?seq=502235\&formato=PDF>. Acesso em: 06 jul. 2010. 
TALIDOMIDA banida do mercado há quarenta anos. Disponível em: <http://www.dwworld.de/dw/article/0,,338346,00.html>. Acesso em: 15 jan. 2009.

TAVARES, Juarez. Autoria e participação: apontamentos de aula. UERJ, 2009. Disponível em: <http://www.juareztavares.com/Textos/apontamentos_autoria.pdf $>$. Acesso em: 14 dez. 2010.

. Teoria do injusto penal. Belo Horizonte: Del Rey, 2000.

THE AMERICAN PRESIDENCY PROJECT. John F. Kennedy: XXXV President of the United Stats: 1961-1963. 93 -Special Message to the Congress on Protecting the Consumer Interest. March 15 1962. Disponível em: $<$ http://www.presidency.ucsb.edu/ws/index.php?pid=9108>.

TORON, Alberto Zacharias. Aspectos penais da proteção ao consumidor. Revista Brasileira de Ciências Criminais, São Paulo, v. 3, n. 11, p.80-90, jul./set. 1995.

TV Suíça denuncia carro da Volkswagen do Brasil. Swissinfo, 06 mar. 2007. Disponível em:

<http://www.swissinfo.ch/por/Capa/Archive/TV_Suica_denuncia_carro_da_Volkswagen_ do_Brasil.html?cid=5761928>. Acesso em: 22 nov. 2010.

UNITED NATIONS. General Assembly. A/RES/39/248 - 16 April 1985. Disponível em: $<$ http://www.un.org/documents/ga/res/39/a39r248.htm>.

URQUIZO OLAECHEA, José. El bien jurídico. Revista Peruana de Ciencias Penales, Lima, v. 3, n. 6, p.805-840, jun. 1998. p. 815.

US CONSUMER PRODUCT SAFETY COMMISSION. Crib Information Center. Disponível em: <http://www.cpsc.gov/info/cribs/index.html>. Acesso em: 01 jan. 2010.

VOGEL, Joachim. La responsabilidad penal por el producto en Alemania: situación actual y perspectivas de futuro. Revista Penal La Ley, Salamanca, n. 8, p. 95-104, jul. 2008.

WARAT, Luiz Alberto. Introdução geral ao direito: interpretação da lei: temas para uma reformulação. Porto Alegre: Sergio Antonio Fabris, 1994. v. 1.

WELZEL, H. Derecho penal aleman: parte general. Trad. Juan Bustos Ramírez; Sérgio Yáñez Pérez. 11. ed. Santiago de Chile: Editorial Jurídica de Chile, 1997. 
WELZEL, Hans. Direito penal. Trad. Afonso Celso Rezende. Campinas: Romana, 2003. WIKIPEDIA. Disponível em:<http://ru.wikipedia.org/wiki/>.

WOOLLEY, John T.; PETERS, Gerhard. The American Presidency Project. Santa Barbara, CA. Disponível em: <http://www.presidency.ucsb.edu/ws/?pid=9108>. 